\title{
Biology of the
}

Transuranium Elements

An Indexed Bibliography

Compiled by

Roy C. Thompson

July 1976

Prepared for the Energy Research and Development Administration under Contract E(45-1): 1830 
This report was prepared as an account of work sponsored by the United States Government. Neither the United States nor the Energy Research and Development Administration, nor any of their employees, nor any of their contractors, subcontractors, or their employees, makes any warranty, express or implied, or assumes any legal liability or responsibility for the accuracy, completeness or usefulness of any imformation, apparatus, product or process disclosed, or represents that its use would not infringe privately owned rights.

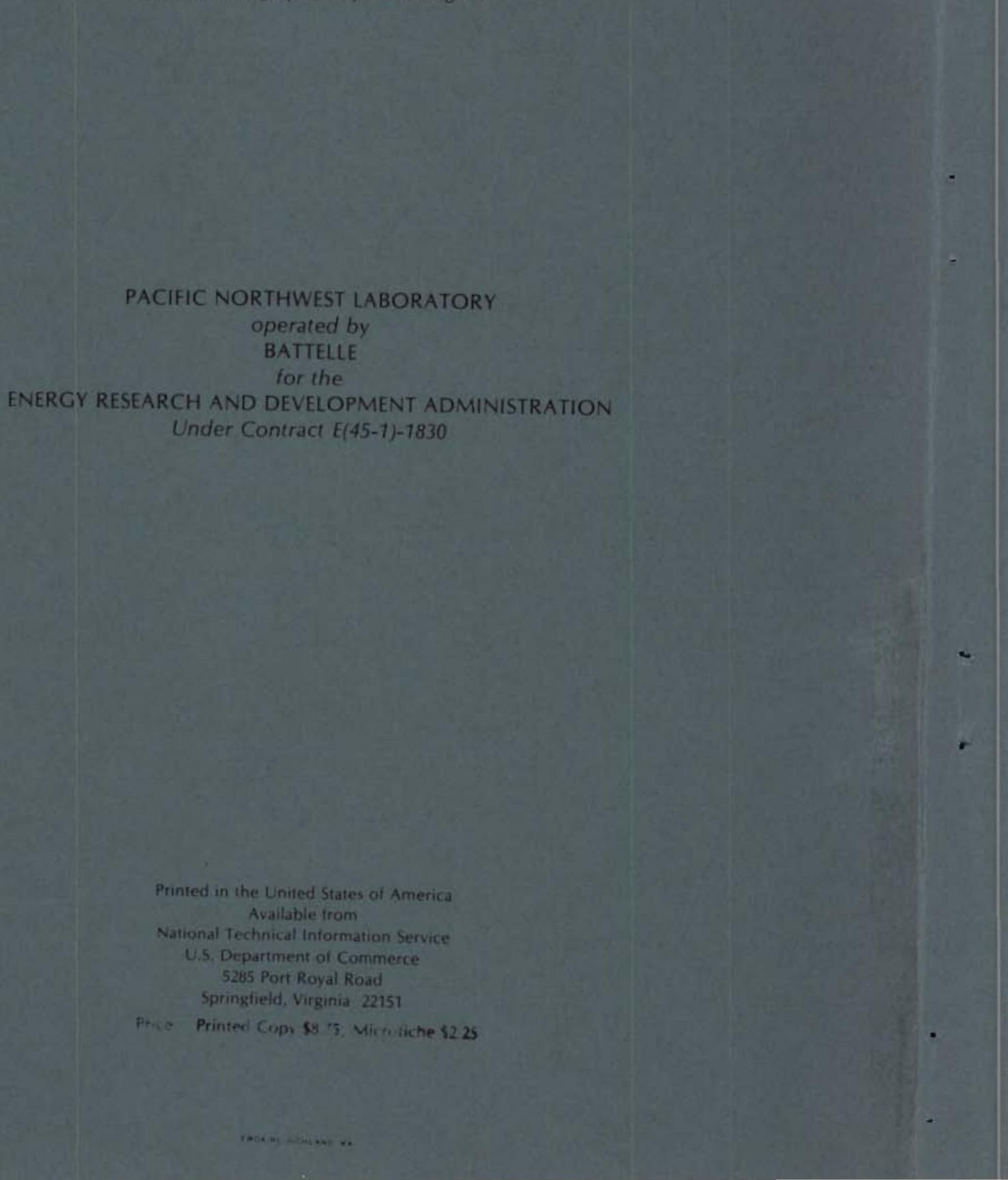


BINLOEY OF THE TRANSURANIUM ELEMENTS

AN INDEXED BIBLIOGRAPHY

$$
\text { compiled by }
$$

Roy C. Thompson

July 1976

BATTELLE

PACIFIC NORTHWEST LABORATORIES

RICHLAND, WASHINGTON 99352 


\section{INTRODUCTION}

This bibliography is a revision of one issued in 1973 (BNWL-1782). It includes essentially all of the citations from the earlier document, a few corrections and additions from the older literature, plus the new literature to mid-1975. It also includes a subject-matter index not present in the original document.

Since the appearance of the first edition of this bibliography, outstanding bibliographic coverage of the transuranic elements, as they relate to the environment, has been provided in "Environmental Aspects of the Transuranics A Selected Annotated Bibliography", published from the Ecological Sciences Information Center of Oak Ridge National Laboratory. Six volumes in this series have been published through 1975, including some 3,700 citations copiously indexed. With this data base in print, and accessible for computer searching, there might seem little reason for the publication of the present document, with fewer than 1,600 citations, and with no claim to kinship with any computer. There is, however, something to be said for a single volume, listing alphabetically by senior author, everything pertinent to a somewhat narrower field of interest than that covered in the Environmental Aspects of the Transuranics. That narrower field of interest, of course, reflects the personal interests and prejudices of the compiler.

The coverage and format of this bibliography remain as described in the first edition. "I have attempted to cover completely, the biological behavior and biological effect of the transuranium elements - "biological" being broadly interpreted to include behavior and effect within natural ecosystems and work locations as well as within discrete organisms. Borderline areas not covered, or represented only by selected articles of special interest, include: applications of transuranium elements where biological effects are not directly involved; monitoring, counting or analytical techniques where biological data are not presented; descriptions of chemical or physical properties where these are not reflected in biological behavior.

"In areas where complete coverage is attempted, this coverage extends only to publications in scientific and technical journals, books, and the published proceedings of scientific meetings. The document literature has been cited selectively, where there seemed reason to believe that the information would not later appear in a more accessible form. Thus, publications in recent periodic reports of major laboratories are not included, but reports from older documents are sometimes included when the information contained is not available el sewhere.

"The bibliographic form should be self-evident. A special effort has been made to reference translations of non-English articles, where such translations 
exist. Each entry includes, where available, reference to an abstract journal, usually Nuclear Science Abstracts (NSA), but occasionally Abstracts of Declassified Documents ( $A D D)$, Biological Abstracts ( $B A)$, Plutonium Documentation (PD), or Environmental Aspects of Plutonium [or, the Transuranics] (EP).

"Associated with each bibliographic entry is a unique code, used in indexing. This code consists of two numbers indicating the year of publication, three letters identifying the senior author, and an additional number if necessary to identify different publications by the same author during the same year. The author code consists of the first three non-repeating letters of the last name; except, where necessary to avoid duplication, the last letter of the code may be derived from the initials of the first or second name, or simply chosen at random. The citations are therefore not always in strictly alphabetical order by code, but are sufficiently close that no difficulty should be encountered in locating a citation by code." While more cumbersome than an accession number, the utility of this code is apparent in index searches, where the code immediately indicates the year of publication, and, for the frequent user, will usually indicate the senior author.

Some familiarity with the plan of the index is required for its efficient use. This plan is completely defined by the list of Index Categories at the beginning of the index section. A more detailed explanation of index categories does not seem necessary. Where these categories are unambiguous, the indexing should be precise. Where the categories are to some degree subjective, the indexing will be correspondingly imprecise.

Some of the index categories may appear to be of marginal utility because of the very large number of entries, but they may still be useful when used in conjunction with other categories. Thus, one might seldom be interested in consulting all publications with data on excreta but one might use such a listing to isolate publications dealing with the excretion of americium by mice following exposure by inhalation. This type of cross-referencing is facilitated by a matrix type of sub-categorization in some of the broader categories.

While some errors will undoubtedly have crept into this compilation, I believe they are few in number. Credit for this achievement must go in large measure to my secretary, Judith Rising, who has been responsible for all clerical work on the bibliography over the past five years, and who typed the manuscript; and also to Patricia Bresina who assisted in the formidable task of proofreading.

As noted in the earlier edition, I would appreciate suggestions concerning any aspect of the presentation or coverage, and would also appreciate receiving reprints of future publications in the field. 
AARKROG, A.

Radio-ecological investigations [Thule incident]

70-ARK

USAF Nuclear Safety 65, (Part 2), Spec. Edition AFRP 122-1,

74-79 (1970) EP 470

AARKROG, A.

Radioecological investigations of plutonium in an arctic marine environment

Health Phys. 20, 31-47 (1971) NSA 25, 21640

AARKROG, A.

Re-examination of plutonium at Thule, Greenland, in 1970

72-ARK

In: Proceedings of International Symposium on Radioecology

Applied to the Protection of Man and $\mathrm{His}$ Environment

(Doc. EUR-4800) 1213-1219 (1972) NSA 27, 5286

AARKROG, A. See also: 70-GJo

ABRAMS, R.

Retention of inhaled plutonium

45-ABR

In: Report of Conference on Plutonium (J. J. Nickson, ed.,

Doc. $\mathrm{CN}-3167)$ 10-11 (1945) EP S3, 289

ABRAMS, R., H. C. Seibert, L. Forker, D. Greenberg, H. Lisco

$46-A B R$

L. 0. Jacobson and E. L. Simmons

Acute toxicity of intubated plutonium

Doc. $\mathrm{CH}-3875,56$ p. (1946) NSA 10,8757

ABRAMS, R., H. C. Seibert, A. M. Potts, L. L. Forker,

D. Greenberg, S. Postel and W. Lohr

Metabolism and distribution of inhaled plutonium in rats

Doc. MDDC-677, 30 p. (1947) ADD 1, 677

ACKERMAN, T. L. See: 73-ROM

ADAMS, W. H., and E. B. Fowler

Plutonium-238 incorporated in fish living in water containing

71-ARK

$2{ }^{38} \mathrm{Pu}-1$ abeled $\mathrm{PuO}_{2}$

Doc. LADC 12899, 8 p. (1970) EP 416

ADAMS, W. H., J. R. Buchholz, C. W. Christenson, G. L. Johnson

and E. B. Fowler

Studies of plutonium, americium, and uranium in environmental matrices

Doc. LA-5661, 24 p. (1975) NSA 31, 14430

ADAMS, W. H. See also: 71-BUJ, 68-FOW

ADEE, R. R., C. L. Sanders and J. D. Berlin

Subcellular localization and identification of alpha emitters by electron microscopic autoradiography

Health Phys. 15, 461-463 (1968) NSA 23, 4889

ADEE, R. R., and J. J. Laidler

Subcellular identification of exogenous particles by highvoltage electron microscopy

Amer. Ind. Hyg. Ass. J. 34, 507-517 (1973) NSA 29, 8100

ADEE, R. R. See also: 68-SAN-2, 69-SAN, 70-SAN-5, 71-SAN

AL-BEDRI, M. B., and S. J. Harris

Dose-equivalent rate in the basal layer of the skin from

241 Am alpha particles

Health Phys. $28,816-818$ (1975) NSA 32, 17468 
ALBERT, R. E.

A critique of the Tamplin-Cochran proposal for revision of the current plutonium exposure standards

In: Doc. WASH-1359, 311-327 (1974)

ALDERHOUT, J., and W. Hunzinger Case of $239 \mathrm{pu}$ inhalation

In: Radiation Protection Problems Relating to Transuranium

Elements (Doc. EUR-4612) 259-271 (1971) NSA 25, 37832

ALDERHOUT, $J$.

Bio-assay results of a case of plutonium inhalation

In: Assessment of Radioactive Contamination in Man (International

Atomic Energy Agency, Vienna) 635-640 (1972) NSA 26, 56507

ALEKSAKHIN, R. M.

Radioactive Contamination of Soil and Plants, Publishing House

of the Academy of Sciences, Moscow, $132 \mathrm{p}$. (1963) translated

in AEC-tr-6631 NSA 18, 12358 EP S1, 289

ALLEN, I. B. See: 67-LAG

ALLKOFER, 0. C., J. M. Fox and H. Hanser Analysis of the alpha-emitting radionuclides from radioactive fallout by alpha spectroscopy (in German)

Atomkernenergie 13, 39-44 (1968) NSA 22, 8224

ALMOND, P. R. See: 73-CAJ

ALOUSH, A. A. See: 72-M0Q

ALVAREZ-RAMIS, C., and A. Gregorides de los Santos Contamination of terrestrial gastropods living in a biological medium with a low level of alpha contamination due to plutonium and uranium

In: Symposium International de Radioecologie. Vol. II.

(Commissariat a 1 'Energie Atomique, Fontenay-aux-Roses,

France) 961-982 (1970) translated in LA-tr-74-11

NSA 24,41867

ALVAREZ-RAMIS, C. See also: 68-FOW

ANDELMAN, J. B., and T. C. Rozzel1

Plutonium in the water environment. I. Characteristics of

70-AND aqueous plutonium

In: Radionuclides in the Environment (American Chemical

Society, Advances in Chemistry No. 93) 118-137 (1970)

NSA 26, 17735

ANDERSEN, B. $V$.

Plutonium aerosol particle size distributions in room air

Health Phys. 10, 899-907 (1964) NSA 18, 29878

ANDERSEN, B. V., and I. C. Nelson

Measurement of plutonium aerosol parameters for application

to respiratory tract models

In: Instruments and Techniques for the Assessment of Airborne

Radioactivity in Nuclear Operations (International Atomic

Energy Agency, Vienna) 185-199 (1967) NSA 21, 32635

ANDERSEN, B. V. See also: 72-BRP, 71-HEI, 72-JEC 
ANDERSON, E. C., L. M. Holland, J. R. Prine and C. R. Richmond

74-ANE

Lung irradiation with static plutonium microspheres

In: Experimental Lung Cancer. Carcinogenesis and Bioassays

(E. Karbe and J. F. Park, eds., Springer-Verlag, Berlin)

430-442 (1974) NSA 31, 15989

ANDERSON E. C. See also: 74-HEA-2

ANDERSON, H. F., W. E. Sheehan, J. R. Mann and R. W. Bistline Evaluation of accidental personnel exposure to plutonium-238. Whole body counting and bioassay results

Health Phys. 18, 631-639 (1970) NSA 24, 48546

ANDERSON, H. F. See also: 72-EDL-2

ANDREEVA, N. A. See: 74-KHO

ANNO, G. H., and C. R. Easton

Population exposure risk from random re-entry of isotopic power devices

In: Nucleonics in Aerospace (P. Polishuk, ed., Plenum Press, New York) 130-137 (1968) NSA 22, 38293

ANSPAugh, L. R., P. L. Phelps, N. C. Kennedy and H. C. Booth Wind-driven redistribution of surface-deposited radioactivity In: Environmental Behavior of Radionuclides Released in the Nuclear Industry (International Atomic Energy Agency, Vienna) 167-184 (1973) NSA 29, 29334

ANSPAUGH, L. R., J. H. Shinn and D. W. Wilson Evaluation of the resuspension pathway toward protective guidelines for soil contamination with radioactivity

In: Population Dose Evaluation and Standards for Man and

His Environment (International Atomic Energy Agency, Vienna)

513-524 (1974) NSA 31, 19555

ANTONCHENKO, G. P., N. A. Koshurnikova and E. R. Lyubchanskii Morphological changes in the lungs of rats after inhalation of large doses of soluble $239 \mathrm{pu}$ compounds

Radiobiologiya 9, 75-80 (1969) translated in AEC-tr-7024, 97-104 NSA 23,24727

ARISTOV, V. P.

Ultrastructure of the alveolar-capillary barrier in rats

following single inhalation of plutonium 239 citrate

In: Biological Effects of Radiation from External and Internal

Sources (Y. I. Moskalev and V. S. Kalistratova, eds.,

Meditsina, Moscow) 257-265 (1972) translated in AEC-tr-7457,

381-390 NSA $\underline{30}, 9967$ EP $\underline{5}, 4$

ARISTOV, V. P. See also: 72-KOS, 73-KOS

ARKHANGELSKAYA, G. V. See: 74-LIK

ARNOLD, J. S.

Exhibit of radioautographs of uranium 233 in bone and soft tissue

Doc. AECD-3176, 17 p. (1951) EP S2, 113

ARNOLD, J. S.

Radioautography

Doc. AECD-3191, 4 p. (1951) EP S2, 110

70-ANH

68-ANO

73-ANS

74-ANS

69-ANT

72-ARI

51-ARN

51-ARN-2 
ARNOLD, J. S.

56-ARN

Some observations on plutonium and radium in bone

In: Therapy of Radioelement Poisoning (M. W. Rosentha], ed.,

Doc. ANL-5584) 131-143 (1956) EP S2, 199

ARNOLD, J. S., and W. S. S. Jee

Bone growth and osteoclastic activity as indicated by radio-

57-ARN autographic distribution of plutonium

Am. J. Anat. 101, 367-417 (1957) BA 34, 7610

ARNOLD, J. S., and W. S. S. Jee Autoradiography in the localization and radiation dosage of $\mathrm{Ra}^{226}$ and $\mathrm{Pu}^{2} 39$ in the bones of dogs

Lab. Invest. 8, 194-204 (1959) BA 33, 39989

ARNOLD, J. S., and W. S. S. Jee Pattern of long-term skeletal remodeling revealed by radioautographic distribution of $\mathrm{Pu}^{239}$ in dogs

Health Phys. 8, 705-707 (1962) NSA 17, 10329

ARNOLD, J. S., and C. T. Wei

Quantitative morphology of vertebral trabecular bone

In: Radiobiology of Plutonium (B. J. Stover and W. S. S. Jee, eds., J. W. Press, Salt Lake City) 333-354 (1972)

ARNOLD, J. S. See a 1so: 60-JEW, 60-JEW-2, 61-JEW, 62-JEW-2, $62-\mathrm{JEH}-3$

ASIMACOPOULOS, P. J. See: 73-NOM

ASLING, C. W., and G. Thilo

Radioautographic studies of the pulmonary deposition of plutonium aerosols

DoC. AECD-3448, 34-47 (1952) EP S2, 119

ASL ING, C. W., J. G. Hamilton, D. Axelrod-Heller and B. J. Louie Localization of certain alkaline and rare earth elements in the costochondral junction of the rat

Anat. Rec. 113, 285-300 (1952) BA 27, 1098

ATHERTON, D. R., and R. D. Lloyd

Distribution and retention of $24{ }^{9} \mathrm{Cf}$ in beagle soft tissue

59-ARN

62-ARN

Health Phys. 22, 675-677 (1972) NSA 26, 38780

ATHERTON, D. R. See also: 69-BRU-2, 72-BRU, 70-LOR, 72-LOR-2, 74-LOR, 75-LOR, 69-MAY, 59-STB-2, 62-STB, 62-STB-2, 68-STB, 69-STB, 71-STB, 72-STB-3, 72-STB-4, 74-STB, 75-STW, 74-TAG

ATKINS, H. L., R. G. Fairchild and J. S. Robertson Comparison of irradiation by ${ }^{252} \mathrm{Cf}$ and radium on the skin of swine

Radiology 96, 161-165 (1970) NSA 24, 39574

ATKINS, H. L., R. G. Fairchild and J. S. Robertson

72-ATK Dose-rate effects on RBE of californium and radium reactions of pig skin

Radiology 103, 439-442 (1972) NSA 26, 38697

ATKINS, H. L., R. G. Fairchild and R. M. Drew Biological properties of ${ }^{252} \mathrm{Cf}$

$52-A S L$

$52-A S L-2$

Amer. J. Roentgenol., Radium Ther. Nuc1. Med. 117, 704-710

(1973) NSA 27, 24921

ATKINS, H. L. See a1so: 72-DRM, 69-FAI, 70-FAI, 70-FAI-2, 73-FAI 
AUDREN, M. L. See: 64-JEA

AUERBACH, S. I. See: 60-0LS

AXELROD, D. J. See: 52-ASL-2, 47-COP, 46-SCK-2, 48-SCK, 48-SCK-2, 49-SCK, 49-SCK-2 
BAINS, M. E. D. See: 70-RAM

BAIR, W. j., and F. P. Hungate Chemical toxicity of plutonium in yeast

In: Doc. HW 47500, 195-200 (1958) NSA 13, 9553 EP 565

58-BAI

BAIR, W. J.

Radioisotope toxicity: From pulmonary absorption

60-BAI

In: Radioisotopes in the Biosphere (R. S. Caldecott and

L. A. Snyder, eds., Univ. of Minnesota) 431-448 (1960)

NSA 14,23888

BAIR, W. J., O. H. Willard and L. A. Temple

$61-\mathrm{BAI}$

Plutonium inhalation studies. I. The retention and

translocation of inhaled $\mathrm{Pu}^{2}{ }^{39} \mathrm{O}_{2}$ particles in mice

Health Phys. 7, 54-60 (1961) NSA 16, 8504

BAIR, W. J., and B. J. McClanahan

Plutonium inhalation studies II. Excretion and translocation

$61-B A I-2$ of inhaled $\mathrm{Pu}^{2}{ }^{39} \mathrm{O}_{2}$ dust

Arch. Environmental Health 2, 648-655 (1961) NSA 15, 21964

BAIR, W. J., and D. H. Willard

Plutonium inhalation studies IV. Mortality in dogs after inhalation of $\mathrm{Pu}^{239} \mathrm{O}_{2}$

Doc. HW-68803, 24 p. (1961) NSA 15, 24658

BAIR, W. J.

Deposition, retention, translocation and excretion of radioactive particles

In: Inhaled Particles and Vapours (C. N. Davies, ed., Pergamon

Press, New York) 192-207 (1961) NSA 15, 28979

BAIR, W. J., and A. C. Case

Preliminary studies of inhaled dust containing neptunium-237

Doc. HW-70949, 21 p. (1961) NSA 16, 7383

BAIR, W. J., and D. H. Willard

Plutonium inhalation studies IV. Mortality in dogs after inhalation of $\mathrm{Pu}^{2}{ }^{39} \mathrm{O}_{2}$

Radiat. Res. 16, 811-821 (1962) NSA 16, 21886

BAIR, W. J., A. D. Wiggins and L. A. Temple

The effect of inhaled $\mathrm{Pu}^{2}{ }^{39} \mathrm{O}_{2}$ on the life span of mice

Health Phys. $8,659-663(1962)$ NSA 17, 10323

BAIR, W. J., D. H. Willard, J. P. Herring and L. A. George, II Retention, translocation and excretion of inhaled $\mathrm{Pu}^{2}{ }^{39} \mathrm{O}_{2}$

Health Phys. 8, 639-649 (1962) NSA 17, 10321

BAIR, W. J., and D. H. Willard

Plutonium inhalation studies. III. Effect of particle size and total dose on deposition, retention and translocation

Health Phys. $\underline{9}, 253-266$ (1963) BA 44,17527

BAIR, W. J., E. G. Tombropoulos and J. F. Park Distribution and removal of transuranic elements and cerium deposited by the inhalation route

In: Diagnosis and Treatment of Radioactive Poizoning

(International Atomic Energy Agency, Vienna) 319-344 (1963)

NSA 17, 2769 
BAIR, W. J., B. 0. Stuart, J. F. Park and W. J. Clarke

64-BAI

Factors affecting retention, translocation and excretion of radioactive particles

In: Radiological Health and Safety in Mining and Milling of

Nuclear Materials, Vol. I (International Atomic Energy Agency, Vienna) 253-274 (1964)

BAIR, W. J., J. F Park and W. J. Clarke Long-term study of inhaled plutonium in dogs

Doc. AFWL-TR-65-214, 58 p. (1966) NSA 20, 31025

BAIR, W. J., and J. F. Park Comparative disposition of four types of plutonium dioxides inhaled by dogs

In: Proceedings of the First International Congress of Radiation Protection, Pt. 1 (W. S. Snyder, et al., eds., Pergamon Press, Oxford) 181-197 (1968) NSA 20, 45273

BAIR, W. J., and V. H. Smith Radionuclide contamination and removal

Prog. Nuc1. Energy, Ser. XII, $\underline{2}, 157-223$ (1969) PD $\underline{4}, 1681$

BAIR, W. J.

Inhalation of radionuclides and carcinogenesis

In: Inhalation Carcinogenesis (M. G. Hanna, Jr., et al., eds., Doc. CONF-691001) 77-101 (1970) NSA 24, 27703

BAIR, W. J. Toxicology of inhaled plutonium

In: Proceedings of the 11th AEC Air Cleaning Conference,

Richland, WA, 1970 (M. W. First and J. M. Morgan, Jr., eds.,

Doc. CONF-700816, Vol. 2) 697-720 (1970) NSA 25, 21836

BAIR, W. J.

Toxicity of inhaled plutonium (in Japanese)

Hoshasen Kagaku 13, 217-221 (1970) NSA 25, 26599

BAIR, W. J. (Chmn.), G. C. Butler, G. W. Dolphin, A. K. Ganguly,

H. Jacobs, J. Lafuma, O. Matsuoka and V. P. Shamov Detection and Assessment of Uranium and Plutonium in the Whole Body and in the Critical Organs, International Atomic Energy Agency, Vienna (1970)

BA.IR, W. J.

Toxicology of inhaled plutonium: Experimental animal studies

In: Radiation Protection Problems Relating to Transuranium

Elements (Doc. EUR-4612) 145-185 (1971) NSA 25, 23989

BAIR, W. J., J. E. Ballou, J. F. Park and C. L. Sanders

$66-B A I$

68-BAI

$69-B A I$

70-BAI

$70-B A I-2$

Plutonium in soft tissues with emphasis on the respiratory tract

In: Uranium-Plutonium-Transplutonic Elements (H. C. Hodge, J. N. Stannard and J. B. Hursh, eds., Springer-Verlag, New York) 503-568 (1973) PD 8, 1021

BAIR, W. J., and R. C. Thompson

Plutonium: Biomedical research

Science 183, 715-722 (1974) NSA 29, 21229

BAIR, W. J.

Toxicology of plutonium

Advan. Radiat. Biol. 4, 255-315 (1974) NSA 32, 22658 
BAIR, W. J., C. R. Richmond and B. W. Wachholz A radiobiological assessment of the spatial distribution of radiation dose from inhaled plutonium

Doc. WASH-1320, 47 p. (1974) NSA 31, 3756

BAlR, W. J., D. H. Willard, I. C. Nelson and A. C. Case Comparative distribution and excretion of $237 \mathrm{Pu}$ and $239 \mathrm{Pu}$ nitrates in beagle dogs

Health Phys. 27, 392-396 (1974) NSA 31, 6379

BAIR, W. J. Biological effects of transuranium elements in experimental animals (part of AEC presentation at EPA Plutonium Standards Hearings, December 10-11, 1974)

In: Doc. WASH-1359, 171-229 (1974) NSA 31, 16857

BAIR, W. J. Considerations in assessing the potential harm to populations exposed to low levels of plutonium in air

In: Population Dose Evaluation and Standards for Man and His

Environment, International Atcmic Energy Agency, Vienna, 435-449

(1974) NSA 29, 13014

BAIR, W. J. Consideration of reactor accident exposure guides for plutonium

In: Proceedings of the Fast Reactor Safety Meeting, Doc. CONF-

740401-PI NSA 30, 7140

BAIR, W. J. See also: 62-BAL-2, 72-BUS, 64-CLA, 64-CLA-2, 65-CLA, 66-CLA, 62-PAR, 64-PAR, 65-PAR, 69-PAR, 72-PAR, 70-SAN-2, 70-SAN-3, 68-STU, 70-STU, 59-TEM, 60-TEM, 58-THO, 72-TH0, 72-THO-2, 63-TOM, 64-WES

BAISOGOLOV, G. D., and V. N. Podgorodetskaya Hematopoiesis in dogs during subacute intoxication induced by plutonium-239

In: Distribution, Biological Effects, and Rapid Excretion of Radioactive Isotopes (Y. I. Moskalev, ed., Meditsina, Moscow) 225-229 (1964) translated in AEC-tr-7590, 238-242 NSA 19, 40379

BAISOGOLOV, G. D. See a'7so: 64-PLO

BAKER, D. A. See: 73-SOL

BAKER, T. P., Jr., B. B. Boecker and J. L. Dick Aircraft accidents involving plutonium contamination

Doc. AFSWC-TN-58-3, 13 p. (1958) NSA 15, 26386 EP 732

BALABUKHA, V. S., and G. Y. Fradkin Accumulation of Radioactive Elements in the Organism and Their Elimination (in Russian), Medgiz, Moscow, 182 p. (1958) NSA 13,17756

BALLADA, $J$.

Analytic determination of plutonium in the environment (in French)

Doc. CEA-R-3220, 157 p. (1967) NSA 22, 1945

BALLADA, J. See also: 71-JEA

BALLOU, J. E., and W. D. Oakley

Absorption and decontamination of plutonium on rats

64-BAD

$74-B A I-6$

In: Doc. HW-47500, 142-145 (1957) EP $\underline{53}, 40$ 
BALLOU, J. E.

$58-B A L$

Effects of age and mode of ingestion on absorption of plutonium

Proc. Soc. Expt1. Biol. Med. 98, 726-727 (1958) NSA 12, 16918

BALLOU, J. E.

Wound decontamination with EDTA

In: Doc. HW-69500, 111-113 (1961) NSA 15, 27364

BALLOU, J. E., L. A. George II and R. C. Thompson

The combined toxic effects of plutonium plus $x$-ray in rats

Health Phys. 8, 581-587 (1962) NSA 17, 10318

BALLOU, J. E., W. J. Bair, A. C. Case and R. C. Thompson

Studies with neptunium in the rat

Health Phys. 8, 685-688 (1962) NSA 16, 30196

BALLOU, J. E.

Preliminary evaluation of several chelating agents for

plutonium removal

Health Phys. $8,731-734$ (1962) NSA 17, 10334

BALLOU, J. E.

Removal of deposited plutonium by triethylenetetramine

$62-B A L-4$

hexaacetic acid

Nature 193, 1303-1304 (1962) NSA 16, 14436

BALLOU, J. E.

Distribution and retention of plutonium-239 and neptunium-237

in the rat adrenal

Radiat. Res. 22, 81-94 (1964) NSA 18, 23221

BALLOU, J. E., and J. L. Palotay

Oral therapy for deposited plutonium

Health Phys. 12, 895-899 (1966) NSA 20, 35213

BALLOU, J. E., R. C. Thompson, W. J. Clarke and J. L. Palotay

Comparative toxicity of $238 \mathrm{pu}$ and $239 \mathrm{Pu}$ in the rat

Hea1th Phys. 13, 1087-1092 (1967) NSA 21, 45544

BALLOU, J. E., and J. O. Hess

Biliary plutonium excretion in the rat

Health Phys. 22, 369-372 (1972) NSA 26, 23201

BALLOU, J. E., J. F. Park and W. G. Morrow

Metabolic equivalence of ingested, injected and inhaled $239 \mathrm{Pu}$ citrate

Health Phys. 22, 857-862 (1972) NSA 26, 38799

BALLOU, J. E. See al so: 72-BAI, 73-BAI, 72-HUF, 57-NEF, 61-SMV, 56-WEK

64-BAL

$66-B A L$

67-BAL

72-BAL

$72-B A L-2$

BAMBERG, S. A. See: 73-ROM

BANKERT, L. See: 71-CUM

BARBER, A. J. See: 46-SCK-2

BARR, N. F.

Assessment of potential health consequences of transuranium elements

In: Population Dose Evaluation and Standards for Man and His

Environment (International Atomic Energy Agency, Vienna) 451-492

(1974) NSA 31, 20083 
BARRON, E. S. G., and J. Muntz

45-BAR

Studies on the mechanism of $\mathrm{Pu}$ intoxication

In: Doc. CN-2786, 4-7 (1945) EP 5, 355

BARRON, E. S. G.

Metabolism of tissues of plutonium treated rats

$45-B A R-2$

In: Report of Conference on Plutonium (J. J. Nickson, ed., Doc.

CN-3167) 12-15 (1945) EP S3, 290

BARRON, E. S. G. See also: 47-MUN, 45-RUE

BARTLEY, M. H. Jee: 69-JEW

BARTON, C. J.

Hazard of dispersed plutonium particles

$66-B A C$

Nucl. Safety $\underline{7}, 468-473$ (1966) NSA 20, 45988

BASSETT, S. H. See: 50-LAN

BATES, T. H. See: 64-SMH, 65-SMH

BAUM, J. W. See: 58-ROE

BALMGARTNER, W. V. See: 68-LAR

BAXTER, D. W., and M. F. Sullivan

Gastrointestinal absorption and retention of plutonium chelates

72-BAX

Health Phys. 22, 785-786 (1972) NSA 26, 38792

BAXTER, D. W., M. W. Rosentha1, J. J. Russell, E. Moretti,

73-BAX

$D$. Chl adek and $A$. Lindenbaum Comparison of monomeric and polymeric plutonium in the dog and mouse

Radiat. Res. 54, 556-565 (1973) NSA 28, 15813

BAXTER, D. W., M. W. Rosenthal and A. Lindenbaum Decorporation of monomeric plutonium from the dog by glucan and/or DTPA

Radiat. Res. 55, 144-152 (1973) NSA 28, 21828

BAXTER, D. W. See also: 72-HUF

BAY, R. C. See: 55-D0J

BEACH, S. A., and G. W. Dolphin Determination of plutonium body burdens from measurements of daily urine excretion

In: Assessment of Radioactivity in Man, Vol. 2 (International

Atomic Energy Agency, Vienna) 603-616 (1964) NSA 18, 33267

BEACH, S. A., G. W. Dolphin, K. P. Duncan and H. J. Dunster Basis for routine urine sampling of workers exposed to $239 \mathrm{Pu}$ Health Phys. 12, 1671-1682 (1966) NSA 21, 18061

BEACH, S. A.

SEBEACH, a digital computer program for the estimation of body content of plutonium from urine data

Health Phys. 24, 9-16 (1973) NSA 27, 7795

BEAMER, J. L. See: 68-SMV, 74-SUL

BELYAEV, Y. A.

The physico-chemical state of plutonium $\left(\mathrm{Pu}^{239}\right)$ in the blood

Med. Radiol. 4(9), 45-51 (1959) NSA 14, 1336 
BELYAEV, Y. A.

60-BEL

The influence of the calcium disodium salt of diaminocyclohexane-

tetra-acetic acid on plutonium metabolism in rats

Med. Radiol. 5(2), 54-58 (1960) translated in JPRS-5078, 131-141

NSA 14,12512

BELYAEV, Y. A.

The use of ion-exchange resins for the removal of plutonium from

the gastrointestinal tract

Med. Radiol. 5(3), 44-47 (1960) translated in JPRS-5124, 110-116

NSA 14,13572

BELYAEV, Y. A.

Possible ways of influencing the elimination of plutonium from

the animal organism

In: Biological Effects of Radiation and Problems of Radioactive

Isotope Distribution (A. V. Lebedinski i and Y. I. Moskalev, eds.,

Atomizdat, Moscow) 182-189 (1961) translated in AEC-tr-5265,

180-187 NSA 16, 9919 EP S2, 296

BELYAEV, Y. A., V. V. Konstantinova and N. I. Elkina

Plutonium distribution in rabbits

In: Plutonium-239: Its Distribution, Biological Effect and

Accelerated El imination (A. V. Lebedinskii and Y. I. Moskalev, eds., Medgiz, Moscow) 7-11 (1962) translated in FTD-TT-63-559, $1-7 \quad$ NSA 17, 30269

BELYAEV, Y. A., N. I. Elkina, V. V. Konstantinova and I. A. Tseveleva

Toxicologic properties of sodium plutonyl triacetate and its

distribution in the rat body

In: Plutonium-239: Its Distribution, Biological Effect and

Accelerated Elimination (A. V. Lebedinski $i$ and $Y$. I. Moskalev, eds., Medgiz, Moscow) 19-22 (1962) translated in FTD-TT-63-559, 19-24 NSA 17,30271

BELYAEV, Y. A.

Chemical forms of plutonium $\left(\mathrm{Pu}^{239}\right)$ in the liver and spleen of the rat

In: Plutonium-239: Its Distribution, Biological Effect and

Accelerated Elimination (A. V. Lebedinski $i$ and $Y$. I. Moskalev, eds., Medgiz, Moscow) 45-51 (1962) translated in FTD-TT-63-559, 58-69 NSA 17, 30275

BELYAEV, Y. A.

Effect of ion exchange resins and complexons on distribution of plutonium introduced into the gastrointestinal tract

In: P1utonium-239: Its Distribution, Biological Effect and Accelerated Elimination (A. V. Lebedinskii and $Y$. I. Moskalev, eds., Medgiz, Moscow) 151-155 (1962) translated in FTD-TT-63-559, 230-236; and in JPRS-16900, 66-74 NSA 17, 12105

BELYAEV, Y. A.

Effect of some complexons on plutonium removal in rats

$60-B E L-2$

$61-B E L$

$62-B E L$

$62-B E L-2$

$62-B E L-3$

In: Plutonium-239: Its Distribution, Biological Effect

and Accelerated Elimination (A.V. Lebedinskii and

Y. I. Moskalev, eds., Medgiz, Moscow) 156-161 (1962) translated

in FTD-TT-63-559, 237-245; and in JPRS-16900, 75-86 NSA 17,

12106

BELYAEV, Y. A.

Comparative effectiveness of some complexants in removing $239 \mathrm{Pu}$

64-BEL

from animal organs

Radiobiologiya $4,760-763$ (1964) translated in AEC-tr-6408,

125-128 NSA $1 \overline{9}, 6975$ 
BELYAEV, Y. A., and V. K. Lemberg

64-BEL-2

Effectiveness of DTPA after intratracheal administration of plutonium to rats

In: Distribution, Biological Effects, and Rapid Excretion of

Radioactive Isotopes (Y. I. Moskalev, ed., Meditsina, Moscow)

343-347 (1964) translated in AEC-tr-7590, 361-366 NSA 19, 40346

BELYAEV, Y. A.

Oral administration of some complexing agents to remove plutonium from rats

In: Distribution, Biological Effects and Rapid Excretion of

Radioactive Isotopes (Y. I. Moskalev, ed., Meditsina, Moscow)

338-342 (1964) translated in AEC-tr-7590, 356-360 NSA 19, 40345

BELYAEV, Y. A.

Americium-241 distribution in rats and the effect of complexing substances on its elimination

In: Radioactive Isotopes and the Body (Y. I. Moskalev, ed.,

Meditsina, Moscow) (1969) translated in AEC-tr-7195, 168-174

NSA 25, 23967

BELYAEV, Y. A. See also: 68-BUK

BENNETT, B. G.

Fallout $239 \mathrm{Pu}$ dose to man

In: Doc. HASL-278, I-41 - I-63 (1974)

BENNETT, B. G.

Fallout $239,240 \mathrm{Pu}$ in diet

In: Doc. HASL-286, I-36 - I-52 (1974) EP $\underline{6}, 300$

BENNETT, G. B.

Environmental pathways of transuranic elements (part of AEC presentation at EPA Plutonium Standards Hearings, December $10-11,1974$ )

In: Doc. WASH-1359, 131-152 (1974) NSA 31, 16540

BENO, $M$.

A study of 'hemosiderin' in the marrow of the femur of normal young adult rabbits compared with that in rabbits 4 months after an intravenous injection of $239 \mathrm{Pu}\left(\mathrm{NO}_{3}\right)_{4}$

Brit. J. Haematol. 15, 487-493 (1968) NSA 23, 33636

BENSON, R. E. See: 68-ODL-2

BENSTED, J. P. M., D. M. Taylor and F. D. Sowby

The carcinogenic effects of $241 \mathrm{Am}$ and $239 \mathrm{Pu}$ in the rat

65-BEN

Brit. J. Radiol. 38, 920-925 (1965) NSA 20, 5321

BENSTED, J. P. M., and D. M. Taylor

A comparison of the carcinogenic effects of the boneseeking nuclides, $241 \mathrm{Am}$ and $239 \mathrm{Pu}$

In: Symposium Ossium (A. M. Jelliffe and B. Strickland, eds.,

Livingstone, London) 211-214 (1969) NSA 25, 24374

BENSTED, J. P. M. See also: 69-TAY-2

BERGER, R., R. Boucher, B. Jampsin and C. Devillers

$2{ }^{38} \mathrm{Pu}$ sources for cardiac pacemakers (in French)

In: Radiation Protection Problems Relating to Transuranium Elements,

Doc. EUR-4612, 115-141 (1971) NSA 25, 37816

BERGSTRAND-JINKINS, P. See: 61-FIN 
BERLIN, J. D., and D. D. Mahlum

Comparative morphologic and functional studies of neptunium-

70-BEJ induced fatty livers in rats

Lab. Invest. ?2, 252-259 (1970) NSA 24, 23092

BERLIN, J. D. See also: 68-ADE

BERLINER, D. L., M. L. Berliner and T. F. Dougherty

The effects of chronic irradiation by internally deposited

$62-B E D$ radionuclides on corticosteroid biosynthes is

In: Some Aspects of Internal Irradiation (T. F. Dougherty, et al.,

eds., Pergamon Press, New York) 179-186 (1962) NSA 17, 19894

BERLINER, D. L., W. Stevens, C. J. Nabors, Jr., and R. E. Maxwe 11 Biochemical changes induced by internally deposited radionuclides in beagle dog blood: A statistical study

In: Delayed Effects of Bone-Seeking Radionuclides (C. W. Mays,

et a1., eds., Univ. of Utah Press, Salt Lake City) 471-488 (1969)

NSA 23,38795

BERLINER, D. L. See also: 68-ELI, 65-RUH, 64-5TW, 67-STW

BERLINER, M. L. See: 62-BED

BERRY, R. J., G. D. 0liver, Jr., D. L. George, J. Werner

and J. T. Brennan

Survival of murine leukaemia cells exposed to ${ }^{252} \mathrm{Cf}$ neutrons under conditions simulating implantation of those sources into tissue in radiotherapy

Brit. J. Radiol. 46, 996-1004 (1973) NSA 29, 24488

BEVAN, J. S., and A. K. M. M. Haque

Some speculations on the carcinogenic effect of inhaled alphaactive material

Phys. Med. Biol. 13, 105-112 (1968) NSA 22, 28680

BILKIEWICZ, J. See: 71-JAW, 73-JAW, 73-JAW-2

BISKIS, B. 0. See: 61-FIN, 62-FIN, 68-FIN

BISTLINE, R. W., R. L. Watters, and J. L. Lebel

Study of translocation dynamics of plutonium and americium from simulated puncture wounds in beagle dogs

Health Phys. 22, 829-831 (1972) NSA 26, 38796

BISTLINE, R. W.

Translocation dynamics of 239-plutonium

69-BED

73-BEY

$68-B E V$

Thesis, Colorado State University, Doc. CO0-1787-20, 155 p.

(1973) NSA 29, 13052

BISTLINE, R. W. See also: 70-ANH, 74-GOM

BLACKBURN, K. E. See: 68-0DL

BLAIR, H. A.

The shortening of life span by a single injection of radium, plutonium, or polonium

Radiat. Res., Supp1. 5, 216-227 (1964) NSA 19, 2056

BLAIR, H. A. Radiation dose-time relations for induction of bone tumors in the dog and skin tumors in the rat

Radiat. Res. $34,501-522$ (1968) NSA 22, 47581 
BLAIR, H. A.

72-BLA

Radiation dose-time relations for induction of osteosarcoma

in mice and dogs and their bearing on maximal permissible burden of $90 \mathrm{Sr}$ in man

Health Phys. 23, 759-765 (1972) NSA 27, 2811

BLAKE, L. W. See: 62-TAD

BLAND, M. R., J. F. Loutit and J. M. Sansom

Histochemical phosphatase and metachromasia in murine tumours

induced by bone-seeking radionuclides

Brit. J. Cancer 29, 202-222 (1974) PD 8, 3234

BLEANEY, B.

Radiation dose-rates near bone surfaces in rabbits after

injection of plutonium

Phys. Med. Biol. 12, 145-160 (1967) NSA 21, 20190

BLEANEY, B.

The radiation dose-rates near bone surfaces in rabbits after

intravenous or intramuscular injection of $239 \mathrm{Pu}$

Brit. J. Radiol. 42, 51-56 (1969) NSA 23, 31761

BLEANEY, B.

Plutonium deposition on bone surfaces and in bone marrow

following intravenous and intramuscular injections

In: Delayed Effects of Bone-Seeking Radionuclides (C. W. Mays,

et al., eds., Univ. of Utah Press, Salt Lake City) 125-135 (1969)

NSA 23,38422

BLEANEY, B., and J. Vaughan

Distribution of ${ }^{239} \mathrm{Pu}$ in the bone marrow and on the endosteal

surface of the femur of adult rabbits following injection of $239 \mathrm{Pu}\left(\mathrm{NO}_{3}\right)_{4}$

Brit. J. Radiol. 44, 67-73 (1971) NSA 25, 16015

BLEANEY, B. See also: 67-VAU, 73-VAU

BLISS, W., and L. Dunn

Measurement of plutonium in soil around the Nevada test site

In: Proceedings of Environmental Plutonium Symposium (E. G.

Fowler, et al., eds., Doc. LA-4756) 89-92 (1971) Also in:

Proceedings of the Rocky Flats Symposium on Safety in Plutonium Handling Facilities (Doc. CONF-710401) 320-327 (1971) NSA 25, 54755

BLOOM, M: A.

Bone Marrow

48-BLO

In: Histopathology of Irradiation from External and Internal

Sources (W. Bloom, ed., McGraw Hill, New York) 162-242 (1948)

BLOOM, M. A., and W. Bloom

Late effects of radium and plutonium on bone

Arch. Patho1. 47, 494-511 (1949) NSA 1, 16

BLOOM, W.

Histological changes following radiation exposures

71-BLE

$69-B L E-2$

Radiology 49, 344-347 (1947) BA 22, 13280

BLOOM, W. (Ed.)

Histopathology of Irradiation from External and Internal Sources

71-BL I

McGraw Hill, New York, 808 p. (1948) BA 23, 23043

BLOOM, W.

The ovary

In: Histopathology of Irradiation from External and Internal Sources

(W. Bloom, ed., McGraw Hill, New York) 598-673 (1948)

49-BLO

47-BLW

48-BLW

48-BLW-2 
BLOOM, W.

$48-B L W-3$

The kidney

In: Histopathology of Irradiation from External and Internal Sources

(w. Bloom, ed., McGraw Hi11, New York) 674-703 (1948)

BLOOM, W. See also: 49-BLO

BOCKER, D. V. See: 68-RUN

BOECKER, B. B.

A study of the deposition and excretion of $\mathrm{PuO}_{2}$ in rats (Thesis)

59-B0E

Doc. TID-15685 (1959) NSA $\underline{16}, 18748$

BOGATOV, L. V., and Z. I. Kalmykova

A study of the functional state of the blood system in dogs at remote dates after the chronic action of ionizing radiation

In: Biological Effects of Radiation and Problems of Radioactive

Isotope Distribution (A. V. Lebedinskii and $Y$. I. Moskalev, eds.,

Atomizdat, Moscow) 38-48 (1961) translated in AEC-tr-5265, 32-42

NSA 16, 26865

BOGAtov, L. V., Z. I. Kalmykova, N. P. Kudasheva and S. A. Rogacheva Peculiarities in the course and outcome of radiation sickness in dogs injected intravenously with the nitrate of plutonium-239

In: Plutonium-239: Its Distribution, Biological Effect and

Accelerated Elimination (A. V. Lebedinskii and Y. I. Moskalev,

eds., Medgiz, Moscow) 103-114 (1962) translated in FTD-TT-63-559,

150-172 NSA 18, 15817

BOGATOV, L. V.

Reaction of the blood system in dogs to heavy blood loss in remote periods following chronic irradiation (in Russian)

Med. Radio1. 8(2), 28-35 (1963) NSA 17, 23119

BOGEN, D. See: 62-KRP

BOHNING, D. E. See: 71-FAS

BOKOWSKI, D. L. See: 69-LAG, 71-LAG, 72-LAG-2, 73-LAG

B00COCK, G., and D. S. Popplewe11

Distribution of plutonium in serum proteins following intravenous

injection into rats

Nature 208, 282-283 (1965) NSA 19, 27911

B00COCK, G., and D. S. Popplewell

In vitro distribution of americium in human blood serum proteins

Nature 210, 1283-1284 (1966) NSA 20, 35225

BOOCOCK, G., C. J. Danpure, D. S. Popplewell and D. M. Taylor

The subcellular distribution of plutonium in rat liver

$62-B O G$

$61-B O G$

Radiat. Res. 42, 381-396 (1970) NSA 24, 31817

B00COCK, G. See also: 68-POL, 71-POL

BOOTH, H. C. See: 73-ANS

BOOTMAN, W. R. See: 67-GLA

BORISOVA, V. V. See: 73-SHU, 74-ZAP

BOSS, M. R., and J. R. Mann

$67-B 0 S$

Body counter evaluations of plutonium exposures

Health Phys. 13, 259-266 (1967) NSA 21, 16357

BOUCHER, R. See: 71-BER 
BOUDENE, C. See: 66-TRU, 66-TRU-2, 66-TRU-3

BOULAY, P., J. J. Chivot, L. Jeanmaire and A. Lansiart

$233 \mathrm{~Pa}$ "Pu simulator" for the direct measurement of a pulmonary

67-BOU contamination

Compt. Rend., Ser. D. $265,1571-1574$ (1967) translated in AEC-tr-

6927 NSA 22, $28472 ; \underline{23}, 4925$

BOULAY, P.

Direct measurement of pulmonary plutonium contamination

In: Advances in physical and Biological Radiation Detectors

(International Atomic Energy Agency, Vienna) 287-297 (1971)

NSA 25,57773

BOWEN, V. T., K. M. Wong and V. E. Noshkin

Plutonium-239 in and over the Atlantic Ocean

J. Marine Res. 29, 1-10 (1971) PD 6, 1585

BOWEN, V. T. See also: 71-NOS, 72-NOS, 71-WON

BOWERS, J. Z. See: 55-DOJ

BOYD, G. A., H. E. Silberstein, R. M. Fink, A. Frenkel, W. L. Minto,

R. G. Metcalf, G. Casarett and G. M. Suter

Pilot studies on the intravenous lethal dosage of polonium, plutonium, and radium in rats

In: Biological Studies with Polonium, Radium and Plutonium

(R. M. Fink, ed., McGraw Hill, New York) 211-294 (1950)

NSA $\underline{3}, 17$

BOYD, G. A., A. Williams, W. L. Minto, D. V. Tiedeman, R. M. Fink, G. Casarett and R. G. Metcalf

Simultaneous studies on the intravenous lethal dosage of polonium, plutonium and radium in rats

In: Biological Studies with Polonium, Radium and Plutonium

(R. M. Fink, ed., McGraw Hill, New York) 295-404 (1950)

NSA 3,18 EP S3, 154

BOYD, H. A. See: 74-KAN, 72-KOT, 72-MCR-2, 75-RAB

BRAIN, J. D., and P. A. Valberg

Models of lung retention based on ICRP Task Group report

Arch. Environ. Health 28, 1-11 (1974) NSA 31, 26206

BRAMSON, P. E., J. J. Jech and B. V. Anderson

Comparison of manual and computer evaluation of systemic

$71-\mathrm{BOU}$ plutonium burdens

Health Phys. 22, 917-920 (1972) NSA 26, 38755

BRAMSON, P. E. See also: 72-HEN

BRECHBILL, R. A.

Special bovine sampling study: Project rollercoaster sites

69-BRE

Doc. SWRHL-53r, 23 p. (1969) NSA 23,

38555

BRENNAN, J. T. See: 73-BEY

BRESLIN, A. J. See: 67-GLA

BRETTHAUER, E.W. See: 72-MIL 
BRIGHTWELL, J., and A. G. Heppleston

73-BRI

Inhibition of urethane-induced pulmonary adenomas by inhaled $239 \mathrm{Pu}$

Brit. J. Radio1. 46, 180-182 (1973) NSA 27, 28014

BRIGHTWELL, J., and R. F. Carter

Absorption from the gut of a suspension of plutonium-sodium aerosol

$75-B R I$

Health Phys. 28, 156-158 (1975) NSA 31, 23077

BRINEY, S. A. See: 70-BUC, 72-DEF, 73-BUC

BRoDSKY, A., J. A. Sayeg, N. Wald, R. Wechsler and R. Caldwell

Measurement and management of insoluble plutonium-americium inhalation in man

In: Proceedings of the First International Congress of Radiation

Protection, Part 2 (W. S. Snyder, et a)., eds., Pergamon Press,

New York) 1181-1190 (1968) NSA 23, 14179

BRODSKY, A., N. Wald, R. E. Lee, J. Horm and R. Caldwell

Plutonium-americium contamination aspects of a dry box

accident involving hand amputation

In: Health Physics Operational Monitoring, Vol. 3 (C. A. Will is, ed., Gordon and Breach, New York) 1601-1620 (1972) NSA 29, 29861

BRODSKY, A. See also: 69-BUA, 70-BUA, 71-FAS, 73-SLO, 68-WAL

BROOKS, A. L., R. 0. McClellan and L. R. McKay

Comparison of the relative biological effectiveness of $241 \mathrm{Am}$

and ${ }^{144} \mathrm{Ce}$ on the production of chromosome aberrations in the

Chinese hamster liver

In: Health Physics Aspects of Nuclear Facility Siting. Vol. I I

(P. G. Voilleque, ed., Idaho Falls, Idaho) 600-618 (1971)

NSA 25,55188

BROOKS, A. L., J. A. Mewhinney and R. 0. McClellan

In vivo cytogenetic effects of ${ }^{252} \mathrm{Cf}$ on 1 iver and bone marrow

of the Chinese hamster

Hea 1th Phys. 22, 701-706 (1972) NSA 26, 38742

BR00KS, A. L., J. C. Retherford and R. 0. McClellan

Effect of $239 \mathrm{PuO}_{2}$ particle number and size on the frequency and

distribution of chromosome aberrations in the liver of the

Chinese hamster

Radiat. Res. 59, 693-709 (1974) NSA 30, 29783

BR00KS, A. L. See a1so: 72-MCK, 72-MEW

BROWN, C. L. See: 73-SEL

BROWN, H. See: 73-ROS

BROWN, M. See: 68-SAM

BRUENGER, F. W., W. Stevens and B. J. Stover

$241 \mathrm{Am}$ in the blood: in vivo and in vitro observations

69-BRU

Radiat. Res. 37, 349-360 (1969) NSA 23, 20112

BRUENGER, F. W., B. J. Stover, W. Stevens and D. R. Atherton

Exchange of 239 PuIV between transferrin and ferritin in vitro

$71-B R A$

72-BRO

68-BR0

\author{
$72-B R O$
}


BRUENGER, F. W., D. R. Atherton and W. Stevens

Intracellular distribution of $249 \mathrm{Cf}$ in canine liver

Health Phys. 22, 685-689 (1972) NSA 26, 38782

72-BRU

BRUENGER, F. W. See a1so: 65-STW, 68-STW, 69-STW, 72-STW, 62-STB-2, 68-STB, 68-STB-2, 69-STB, 70-STB, 72-STB-2, 75-STW

BRUES, A. M.

Clinical picture following plutonium administration

45-BRM

In: Report of Conference on Plutonium (J. J. Nickson, ed.,

Doc. CN-3167) 19-26 (1945) EP S3, 292

BRUES, A. M., H. Lisco and M. Finkel

Carcinogenic action of some substance which may be a problem in certain future industries

Cancer Res. 7, 48 (1947) ADD 1, 145

BRUES, A. M.

Comparative chronic toxicities of radium plutonium

Doc. ANL-4799, 20 p. (1951) EP S2, 100

BRUES, A. M. See also: 47-LIS

BRUNER, H. D.

A plutonium registry

In: Diagnosis and Treatment of Deposited Radionuclides (H. A.

Kornberg and W. D. Norwood, eds., Excerpta Medica Foundation, Ams terdam) 661-665 (1968) NSA 23, 24667

BRLINSKILL, R. T., and F. B. Holt

Aerosol studies on plutonium and uranium plants at the Windscale and Springfield Works of the United Kingdom Atomic Energy Authority

In: Assessment of Airborne Radioactivity (International Atomic Energy Agency, Vienna) 463-476 (1967) PD 2, 1691

BUCHHOLZ, J. R., W. H. Adams, C. W. Christenson and E. B. Fowler Summary of a study of the uptake of ${ }^{239} \mathrm{Pu}$ by alfalfa from soils Doc. LADC 12897,4 p. (1971) EP 415

BUCHHOLZ, J. R. See also: 75-ADM, 68-FOW

BUKHTOYAROVA, Z. M., and V. K. Lemberg Tumors developing in rats after intraperitoneal injection of plutonium nitrate ( $\left.\mathrm{Pu}^{2} 39\right)$

Vop. Onkol. $5(8), 140-148$ (1959) translated, 13-24 NSA 14 , 21325

BUKHTOYAROVA, Z. M.

The dynamics of the changes in the bone tissues of rabbits poisoned by plutonium-239

In: Biological Effects of Radiation and Problems of Radioactive

Isotope Distribution (A. V. Lebedinski i and Y. I. Moskalev, eds., Atomizdat, Moscow) 155-163 (1961) translated in AEC-tr-5265, 153-161 NSA 16, 9916,26866

BUKHTOYAROVA, Z. M.

Dynamic changes of bone tissue in rabbits poisoned with plutonium-239

In: Plutonium-239: Its Distribution, Biological Effect and Accelerated Elimination ( $A, V$. Lebedinskij and $Y$. I. Moskalev, eds., Medgiz, Moscow) 142-150 (1962) translated in FTD-TT-63$559,215-229$; and in JPRS-16900, 48-65 NSA 17, 12104

EP $\underline{\$ 3}, 504$ 
BUKHTOYAROVA, Z. M., V. K. Lemberg, R. A. Erokhin and

68-BUK

Y. A. Belyaev

Tumors in rats treated with pentacin after injection of $239 \mathrm{Pu}$

(in Russian)

Vop. Onkol. 14 (8), 71-76 (1968) NSA 23, 2874

BUKHTOYAROVA, Z. M., and A. P. Nifatov

Microdistribution of $239 \mathrm{Pu}$ and the histopathology of the liver

69-BUK

and skeleton of dogs after intravenous administration of the isotope

In: Radioactive Isotopes and the Body (Y. I. Moskalev, ed., Meditsina, Moscow) (1969) translated in AEC-tr-7195, 364-375

NSA 25,23985

BUKHTOYAROVA, Z. M., and M. G. Poplyko

Cell composition of the wall of the pulmonary alveoli of rats after

a single inhalation of monomer and polymer forms of plutonium-239

Radiobiologiya 14, 555-558 (1974) translated in AEC-tr-7602, $102-$

107 NSA 31,20087

BUKHTOYAROVA, Z. M. See also: 61-LEM, 62-LEM-2, 66-LEM, 69-LYU-2, 72-PES

BUKOVITZ, A. G., J. A. Sayeg, A. A. Spritzer and A. Brodsky

Effective transmission of the human thorax for photons from

$239 \mathrm{Pu}, 241 \mathrm{Am}$, and other low-energy emitters

Health Phys. 17, 71-75 (1969) NSA 23, 38589

BUKOVITZ, A. G., and A. Brodsky

Reply to comment on "Effective transmission of the human thorax

for photons from $239 \mathrm{Pu}, 241 \mathrm{Am}$, and other low-energy emitters

Health Phys. 19, 585 (1970) NSA 25, 530

BULDAKOV, L. A., and Y. I. Moskalev

Distribution of plutonium-239 in the skeleton and liver of rats and kinetics of $i$ ts elimination depending on the dose and rhythm of the isotope

Radiobiologiya 1, 487-492 (1961) translated in AEC-tr-5425, 37-45

EP S3, 241

BULDAKOV, L. A., Y. I. Moskalev and V. Streltsova

Observations on the biological action of plutonium-239

Biu11. Ekspt1. Biol. i Med. (USSR) 52(11), 57-61 (1961)

translated by Consultants Bureau, $1277-1280$ BA 40, 17347

BULDAKOV, L. A., A. P. Nifatov, N. M. Tolochkova and N. I. Burov Absorption of $239 \mathrm{Pu}$ through the skin and from the subcutaneous tissue of young pigs

Radiobiologiya 7, 591-601 (1967) translated in AEC-tr-6889, 167-

182 NSA 22, $1 \overrightarrow{4925}$

BULDAKOV, L. A.

Behavior of $239 \mathrm{Pu}$ in young pigs

74-BUK

69-BUA

70-BUA

$61-$ BUL

$61-$ BUL-2

Radiobiologiya 8, 62-64 (1968) translated in AEC-tr-6950,

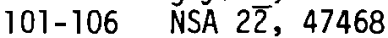

BULDAKOV, L. A., R. A. Erokhin and A. P. Nifatov

Kinetics of the ${ }^{239} \mathrm{Pu}$ metabolism in the case of prolonged peroral administration

Radiobiologiya 8, 900-907 (1968) translated in AEC-tr-7013, 161-171 NSA 23, 17941 
BULDAKov, L. A., E. R. Lyubchanskii, Y. I. Moskalev and A. P.

69-BUL

Nifatov

Problems of Plutonium Toxicology, Atomizdat, Moscow, 368 p. (1969)

translated in LF-tr-41

NSA 23, 35606; 25, 8238, 8594, 8595, 8596, 8674

BULDAKOV, L. A., Z. I. Kalmykova, Y. I. Moskalev and V. N.

69-BULL-2

Streltsova

On the role of the time factor in separate and combined injection with ${ }^{144} \mathrm{Ce}$ and $23{ }^{9} \mathrm{Pu}$

In: Radioactive Isotopes and the Body (Y. I. Moskalev, ed., Meditsina, Moscow) (1969) translated in AEC-tr-7195, 339-346 NSA 25, 24323

BULDAKOV, L. A., Z. I. Kalmykova, N. P. Kudasheva and E. R. Lyubchanski i

The biological effects of inhaled $2.39 \mathrm{Pu}$ (Abstract)

Radiobiologiya 10,794-795 (1970) translated in AEC-tr-7215, 246 PD 5, $396 \overline{1}$

BLILDAKOV, L. A., Z. I. Kalmykova, N. P. Kudasheva, E. R. Lyubchanskii and E. P. Ovcharenko

Biological effect of ${ }^{239} \mathrm{Pu}$ administered by inhalation

In: Remote Aftereffects of Radiation Damage (Y. I. Moskalev, ed., Atomizdat, Moscow) 294-305 (1971) translated in AEC-tr-7387, 323-333 PD 7, 2068

BULDAKov, L. A., A. P. Nifatov, R. A. Erokhin and L. G. Filippova Biological effect of ${ }^{239} \mathrm{Pu}$ with cutaneous and intracutaneous injection

In: Remote Aftereffects of Radiation Damage (Y. I. Moskalev, ed., Atomizdat, Moscow) 350-355 (1971) translated in AEC-tr-7387, 381387 PD $\underline{7}, 2073$ EP $\underline{5}, 38$

BULDAKOV, L. A., A. P. Nifatov and R. A. Erokhin

Biological effect of $239 \mathrm{Pu}$ with chronic peroral administration In: Remote Aftereffects of Radiation Damage (Y. I. Moskalev, ed., Atomizdat, Moscow) 355-365 (1971) translated in AEC-tr-7387, 388-398 PD $\underline{7}, 2074$ EP $\underline{5}, 40$

BULDAKOV, L. A., Z. I. Kalmykova, A. P. Nifatov, V. N. Doshchenko, I. A. Tseveleva, G. S. Mushkacheva, N. P.

Kudasheva, V. M. Pesternikov, V. I. Matveev, A. G. Surina and $V$. N. Karpova

Metabolism and biological effects of inhaled ${ }^{241} \mathrm{Am}$ and ${ }^{239} \mathrm{Pu}$ in dogs

Health Phys. $22,873-874$ (1972) NSA 26, 38750

BULDAKOV, L. A., L. G. Filippova and G. V. Khalturin

Fate of $239 \mathrm{Pu}$ in the case of subcutaneous injection (Abstract)

Radiobiologiya 12, No. 1 (1972) translated in AEC-tr-7316, 234 PD 7, 254

BULDAKOV, L. A.

Toxicology of neptunium 237

In: Biological Effects of Radiation from External and Internal Sources (Y. I. Moskalev and V. S. Kalistratova, eds., Meditsina, Moscow) 214-220 (1972) translated in AEC-tr-7457, 322-329 NSA 30, 9963 
BULDAKOV, L. A., A. P. Nifatov, L. G. Filippova and G. V.

$72-$ BIIL -4

Khalturin

Subcutaneous administration of transuranic elements (neptunium 237, plutonium 239 and americium 241)

In: Biological Effects of Radiation from External and Internal

Sources (Y. I. Moskalev and V. S. Kalistratova, eds., Meditsina,

Moscow) 241-247 (1972) translated in AEC-tr-7457, 359-367

NSA 30, 10013

BULDAKOV, L. A., and A. P. Nifatov

Biological effectiveness of americium 241 following oral and parenteral administration

In: Biological Effects of Radiation from External and Internal

Sources (Y. I. Moskalev and V. S. Kalistratova, eds., Meditsina, Moscow) 305-317 (1972) translated in AEC-tr-7457, 446-454

NSA 30, 10019

BULDAKOV, L. A. See a 15o: 74-KHA, 71-LEV, 71-LEV-2, 72-LEV, 74-LEV-2, 75-LEV, 66-LYU, 61-MOS, 62-MOS, 65MOS, 66-MOS-2, 66-MOS-3, 69-MOS-3, 69-MOS-4, 74-MOS-3, 71-NIF, 71-NIF-2, 72-NIF, 72-NIF-2

BULL, E. H. See: 70-JOL, 70-LEJ

BURDEN, B. A. See: 67-WOR

BURKE, J. C. See: 71-NOS, 71-WON

BURNETT, W. D. See: 72-PAM

BURNHAM, J. B. See: 73-SEL

BUROV, N. I. See: 67-BUL

BURR, W. W.

Biomedical effects of plutonium on humans (part of AEC presentation

74-BUR

at EPA Plutonium Standards Hearings, December 10-11, 1974)

In: Doc. WASH-1359, 231-234 (1974) NSA 31, 16861

BURTON, C. A. See: 68-NGY

BUSCH, H. E. See: 70-GJO

BUSCH, R. H. SEe: 72-PAR

BUSCHBOM, R. L. See: 73-CRD, 75-CRD

BUSEY, H. See: 67-ETI

BUSHONG, S. C., N. Prasad, S. A. Briney and G. D. Oliver Radiocytogenetic determination of the oxygen enhancement ratio of $252 \mathrm{Cf}$

Radiology 96, 167-170 (1970) NSA 24, 39576

BUSHONG, S. C., N. Prasad, S. A. Briney and G. D. 01iver Radiocytogenetic studies with $252 \mathrm{Cf}$

Int. J. Radiat. Biol. 23, 105-112 (1973) NSA 27, 28018

BUSHONG, S. C. See also: 72-DEF

BUSTAD, L. K., W. J. Clarke, L. A. George, II, V. G. Horstman,

R. 0. McClellan, R. L. Persing, L. J. Seigneur and J. L. Terry

62-BUS Preliminary observations on metabolism and toxicity of plutonium in miniature swine

Health Phys. $8,615-620$ (1962) NSA 17, 7748 
BUSTAD, L. K., and R. 0. McClellan

Miniature swine: Development, management, and utilization Lab. Anim. Care 18, 280-287 (1968) NSA 22, 45406

BUSTAD, L. K., M. Goldman, L. S. Rosenblatt, C. W. Mays, N. W. Hetherington, W. J. Bair, R. O. McClellan, C. R. Richmond and R. E. Rowland

Evaluation of long-term effects of exposure to internally deposited radionuclides

In: Peaceful Uses of Atomic Energy, Vol. 11 (United Nations, New York) 125-140 (1972)

BUSTAD, L. K. See also: 62-CAB, 63-CAH, 58-CLA, 56-GE0, 57-GE0, 62MCR, 62-MCR-2, 71-STA, 56-WEK

BUSTER, D. S. See: 62-STB-2, 68-STB, 69-STB, 71-STB, 72-STB-3

BUTLER, G. C. See: 70-BAI-5

BYRD, B. I. See: 73-HAW 
CABLE, J. W., V. G. Horstman, W. J. Clarke and L. K. Bustad

$62-C A B$

Effects of intradermal injections of plutonium in swine

Health Phys. 8, 629-634 (1962) NSA 17, 13920

CALDWELL, R., T. Potter and E. Schnel1

Radiological emergency experience in an industrial plutonium plant

In: Health Physics Operational Monitoring, Vol. 3 (C. A. Willis,

ed., Gordon and Breach, New York) 1581-1599 (1972) NSA 29, 30206

CALDWELL, R. See also: 68-BRO, 72-BRO

CAMPBELL, E. E., W. D. Moss and P. C. Stein

Effect of an evaluated iron and protein diet on plutonium

69-CAM excretion in urine

Health Phys. 16, 764-765 (1969) NSA 23, 35616

CAMPBELL, E. E., M. F. Milligan, W. D. Moss and H. F. Schulte

History of the plutonium bioassay program at the Los Alamos Scientific Laboratory, 1944-1972

Doc. LA-5008, 7 p. (197 ̈) NSA 27, 7364

CAMPBELL, E. E., M. F. Milligan, W. D. Moss, H. F. Schulte

$72-C A L$

and J. F. Mc Inroy

Plutonium in autopsy tissue

Doc. LA-4875, 47 p. (1973)

CAMPBELL, E. E. See also: 69-MOW

CAMPBELL, H. S. See: 67-MOP

CANTRIL, S. T.

Biological basis for maximum permissible exposures

In: Industrial Medicine on the Plutonium Project (R. S. Stone, ed., McGraw-Hi11, New York) 36-74 (1951) EP S2, 91

CANTRIL, S. T. See also: 45-HEM

CARPENTER, G. D.

Plutonium: Personnel exposure control with increasing $240 \mathrm{Pu}$ content

In: Health Physics Operational Monitoring, Vol. 2 (C. A. Willis, ed., Gordon and Breach, New York) 1223-1233 (1972) NSA 29, 29781

72-CAM

73-CAM

CARRITT, J., R. Fryxell, J. Kleinschmidt, R. Kleinschmidt,

47-CAR

W. Langham, A. San Pietro, R. Schaffer and B. Schnap

The distribution and excretion of plutonium administered

intravenously to the rat

J. Biol. Chem. 171, 273-283 (1947) BA 22, 8455

CARROLL, T. E. See: 71-RUA

CARTER, L. A. See: 73-SEL

CARTER, M. W. See: 75-MOG

CARTER, R. E. See: 50-LAN, 51-LAN

CARTER, R. F., and K. Stewart

71-CAF

Oxide fume formed by the combustion of plutonium and uranium

In: Inhaled Particles III (W. H. Walton, ed., Unwin Bros. Ltd., 01d Woking, England) 819-837 (1971) NSA 26, 12273

CARTER, R. F. See also: 75-BRI, 75-STH-2 
CASARETT, G. W.

73-CAG

Pathogenes is of radionuclide-induced tumors

In: Radionuclide Carcinogenesis (C. L. Sanders, et a I., eds.,

Doc. CONF-720505) 1-14 (1973) NSA 26, 45895

CASARETT, G. W. See also: 50-BOY, 50-BOY-2

CASARETT, L. J. Some physical and physiological factors controlling the fate of

60-CAS inhaled substances. II. Retention

Health Phys. 2, 379-386 (1960) NSA 14, 18746

CASARETT, L. J., and P. E. Morrow

Mechanisms of pulmonary clearance of inhaled plutonium dioxide:

68-CAS An autoradiographic study and particle size analysis

In: Proceedings of the First International Congress of Radiation

Protection, Part 1 ( $W$. S. Snyder, et al., eds., Pergamon Press,

New York) 173-180 (1968) NSA 23, 12035

CASARETT, L. J. See also: 61-MOP

CASE, A. C. See: 61-BAI-5, 74-BAI-4, 62-BAL-2, 56-DOC, 58-D0C-2

CASEY, H. W., R. O. McClellan, W. J. Clarke and L. K. Bustad

63- $\mathrm{CAH}$ Acute toxicity of neptunium-237 and its relationship to liver function in sheep

Health Phys. 9, 827-834 (1963) NSA 17, 35292

CASEY, H. W. See also: 62-MCR

CASTLEMAN, A. W., Jr. See: 68-HOR

CASTRO, J. R., G. D. Oliver, H. R. Withers and P. R. Almond Experience with californium-252 in clinical radiotherapy

Amer. J. Roentgenol. Radium Ther. Nucl. Med. 117, 182-194 (1973)

NSA 28, 13048

CATSCH. A.

Radioactive metal mobilization

61-CAT

Federation Proc. 20, Suppl. No. 10, 206-219 (1961) NSA 16,

29327

CATSCH, A.

Principles and trends in therapeutic removal of internally deposited radionuclides

Health Phys. $\underline{8}, 725-730$ (1962) NSA 17, 10333

CATSCH, A.

Toxicology: Radioactive metals

Ann. Rev. Pharmacol. 3, 243-265 (1963) NSA 18, 22

CATSCH, A. See also: 71-SEI

CATT, D. L. See: 74-PAR

CELMA, M. See: 68-FOW

CERNY, E. A. See: 73-RAH

CHAPMAN, I. V. See: 64-SMH, 69-SMH, 69-SMH-2

CHARDACK, W. M. See: 73-LAU

CHASSANY, J. See: 70-ROD 
CHATFIELD, E, J.

68-CHA

The generation of particulate aerosols from plutonium surfaces

Atmos. Environ. 2, 97-101 (1968) NSA 22, 25537

CHATFIELD, E. J.

Some studies of the aerosols produced by the combustion or

69-CHA vaporization of plutonium-alkali metal mixtures. I.

J. Nucl. Mater. 32, 228-246 (1969) NSA 23, 46009

CHATFIELD, E. J.

Some studies of the aerosols produced by the combustion or vaporization of plutonium-alkali metal mixtures. II.

J. Nucl. Mater. 32, 247-267 (1969) NSA 23, 46010

CHERDYNTSEV, V. V., I. V. Kazachevskii, L. D. Sulerzhitskii

65-CHE

and $E$. A. Kuzmina $239 \mathrm{pu}$ in nature

Geochem. Int. (Eng1. trans1.) 2, 918-920 (1965) NSA 21, 34335

CHERRY, R. D., and L. V. Shannon

Alpha radioactivity of marine organisms

At. Energy Rev. 12, 3-45 (1974) PD 8, 2510

CHIFFELLE, T. L. See: 72-THR-2

CHILDRESS, J. D. See: 73-ROM

CHIPPERFIELD, A. R., and D. M. Taylor

Binding of plutonium and americium to bone glycoproteins

$68-\mathrm{CHI}$

Nature 219, 609-610 (1968) NSA 22, 51372

CHIPPERFIELD, A. R., and D. M. Taylor

Binding of plutonium to glycoproteins in vitro

70- $\mathrm{CHI}$

Radiat. Res. 43, 393-402 (1970) NSA 24, 44414

CHIPPERFIELD, A. R., and D. M. Taylor

Binding of americium and plutonium to bone glycoproteins

Eur. J. Biochem. 17, 581-585 (1970) NSA 25, 18899

CHIPPERFIELD, A. R., and D. M. Taylor Binding of thorium(IV), plutonium(IV), americium(III), and curium(III) to the constituents of bovine cortical bone in vitro

Radiat. Res. 51, 15-30 (1972) NSA 26, 43398

CHIPPERFIELD, A. R. See also: 70-TAY, 71-TAY, 71-TAY-2

CHIVOT, J. J. See: 67-BOU

CHLADEK, D. See: 73-BAX, 72-ROS-2, 73-ROS

CHRISTENSEN, W. R., C. C. Smith, C. E. Rehfeld and G. N. Taylor Radiographic changes in internally irradiated dogs

In: Some Aspects of Internal Irradiation (T. F. Dougherty, et a1., eds., Pergamon Press, 0xford) 63-67 (1962) NSA 17, 19887

CHRISTENSEN, W. R., W. S. S. Jee, G. N. Taylor and N. Nebeker Distribution of internal radiation-induced osteogenic sarcoma in various species

In: Radiobiology of Plutonium (B. J. Stover and W. S. S. Jee, eds., J. W. Press, Salt Lake City) 195-202 (1972) NSA 26, 41259

CHRISTENSEN, W. R. See also: 62-DOT, 62-JEW, 69-MAY, 62-TAG, 66-TAG, 69-TAG-2, 71-TAG, 72-TAG-3 
CHRISTENSON, C. W. , and R. G. Thomas

Movement of plutonium through Los Alamos tuff

62-CHW

In: Second Ground Disposal of Radioactive Wastes Conference

(J. M. Morgan, et a1., eds., TID-7628) 248-281 (1962) NSA 16,

25054 EP 8

CHRISTENSON, C. W. See a1so: 75-ADM, 71-BUJ, 68-FOW

CHLITKIN, 0. A. See: 72-ZAY, 72-ZAY-2, 73-ZAY

CLARK, L., Jr. See: 75-FEL

CLARK, R. G. See: 73-SEL

CLARKE, W. J., V. G. Horstman, L. J. Seigneur, J. L. Terry and

58-CLA

L. K. Bustad

Plutonium metabolism in miniature pigs

In: Doc. HW-53500, 102-111 (1958) EP $\underline{52}, 245$

CLARKE, W. J.

Comparative histopathology of $\mathrm{Pu}^{23 \mathrm{~S}}, \mathrm{Ra}^{226}$ and $\mathrm{Sr}^{30}$ in $\mathrm{pig}$ bone

$62-$ CLA

Health Phys. $8,621-627$ (1962) NSA 17, 13919

CLARKE, W. J.

Radiation effects of bone-seeking radionuclides as determined

by histopathological and histochemical studies of swine bone

Thesis, Washington State Univ., Pullman, 191 p. (1962) NSA 17,

15847

CLARKE, W. J., and W. J. Bair

Plutonium inhalation studies. VI. Pathologic effects of inhaled

$64-C L A$ plutonium particles in dogs

Health Phys. 10, 391-398 (1964) NSA 18, 29210

CLARKE, W. J., J. F. Park, J. L. Palotay and W. J. Bair Bronchiolo-alveolar tumors of the canine lung following inhalation of plutonium particles

Am. Rev. Respirat. Diseases, 90, 963-967 (1964) NSA 19, 14963

CLARKE, W.J., J. F. Park and W. J. Bair

Plutonium particle-induced neoplasia of the canine lung. II.

Histopathology and conclusions

In: Lung Tumors in Animals (L. Severi, ed., University of

Perugia, Perugia, Ita1y) 345-355 (1966) NSA 19, 35943

CLARKE, W. J., J. F. Park, J. L. Palotay and W. J. Bair Plutonium inhalation studies. VII. Bronchiolo-alveolar carcinomas of the canine lung following plutonium particle inhalation

Health Phys. 12, 609-613 (1966) NSA 20, 24903

CLARKE, W. J. See also: 64-BAI, 66-BAI, 67-BAL, 62-BUS, 62-CAB, 63-CAH, 65-MAH, 66-MAH, 62-MCR-2, 64-PAR, 65-PAR, 61-SMV

CLAY, A. J. See: 68-ODL

CLINE, J. F. Uptake of $241 \mathrm{Am}$ and $239 \mathrm{Pu}$ by plants

In: Doc. BNWL-714, 8.24-8.25 (1968) PD 2, 4148 EP 731

CLINE, J. F. See also: 55-RED, 66-WID

CLOSE, E. R. See: 72-DUR 
CLOUTIER, R. J., and E. E. Watson

$67-C L 0$

Measuring plutonium in wounds: Advantages of using the americium gamma ray

Health Phys. 13, 811-813 (1967) NSA 22, 4627

CLOUTIER, R. J. See also: 67-LUS

COCHRAN, J.A. See: 70-SHL, 70-SHL-2

COCHRAN, T. В. See: 74-TAM, 74-TAM-2, 74-TAM-3, 75-TAM

COCHRAN, T. H., W. S. S. Jee, B. J. Stover and G. N. Taylor

$62-\mathrm{COH}$

Liver injury in beagles with $P u^{239}$ : Distribution, dosage and damage

Health Phys. 8 , 699-703 (1962) NSA 17, 10328

COCHRAN, T. H. See also: 62-JEW-3

COHEN, N., and M. E. Wrenn

Baboon as an experimental animal for metabolic studies of bone-

$72-$ CON seeking radionuclides in man

In: Medical Primatology 1972. Part III 'E. I. Goldsmith, ed., S. Karger, Base1) 226-236 (1972) NSA 30, 27278

COHEN; N., and M. E. Wrenn

Metabolic characteristics of ${ }^{241} \mathrm{Am}$ in the adult baboon

Radiat. Res. 55, 129-143 (1973) NSA 28, 21826

COHEN, N., R. A. Guilmette and M. E. Wrenn

$74-\mathrm{CON}$

Chelation of $241 \mathrm{Am}$ from the liver and skeleton of the adult baboon

Radiat. Res. 58, 439-447 (1974) NSA 30, 10037

COHEN, N. See also: 72-ROJ, 72-WRE

COHN, S. H. , and J. S. Robertson

Radiotoxicity of internally deposited radioactive material

$64-\cos$

In: Atomic Medicine, 4th Ed. (C. F. Behrens, ed., Williams

\& Wilkins, Baltimore) 251-280 (1964) NSA 19, 15005

COHN, S. H. See: 64-ROB

COLARD, J. See: 71-DUL

COLE, D. W., W. E. Mott and L. A. Sagan

Factors relating to the application of radioisotopes to circulatory-

$70-C O D$ support systems

Isotop. Radiat. Techno1. 1, 134-145 (1970) NSA 24, 14505

COLE, K. S., and C. L. Prosser

Health Problems relating to product

In: Doc. CN-2786, 8-12 (1945) EP $\underline{5}, 50$

COLE, K. S., and C. L. Prosser

Monthly health report on problems relating to product: Biological

$45-\operatorname{COK}-2$ research section

In: Doc. CN-2905, 4-10 (1945) EP $\underline{6}, 24$

COLE, K. S. See also: 45-FIR

COLEMAN, E. J. See: 58-DOC, 59-DOC

COLORADO Department of Health, Division of Occupational and

Radiological Health, Denver, Colorado

USAEC Rocky Flats Plant surveillance

Summary Report, 54 p. (1970) EP 376

COLVETT, R. D. See: 74-HAZ 
COMAR, C. L.

$65-\mathrm{COM}$

Movement of fallout radionuclides through biosphere and man

Ann. Rev. Nucl. Sci. 15, 175-206 (1965) NSA 20, 6714 EP 483

COMAR, C. L. See also: 62-MIH

COPP, D. H., D. J. Axelrod and J. G. Hamilton

The deposition of radioactive metals in bone as a potential

47-COP health hazard

Am. J. Roentgeno1. Rad. Therapy and Nuclear Med. 58, 10-16 (1947)

EP $\underline{S 2}, 14$

COPP, D. H., and B. Kawin

Some considerations in fission product contamination

$56-\operatorname{COP}$

In: Therapy of Radioelement Poisoning (M. W. Rosentha1, ed.,

Doc. ANL-5584) 123-129 (1956) EP S2, 196

COPP, D. H. See also: 50-KAW, 53-KAW, 48-SCK-2

CORLEY, J. P., D. M. Robertson and F. P. Brauer

Plutonium in surface soil in the Hanford plant environs

In: Proceedings of Environmental Plutonium Symposium (E. B.

Fowler, et a1., eds., Doc. LA-4756) 85-88 (1971) PD 6, 2210

CORLEY, J. P. See also: 73-SEL, 73-SOL

CRAIG, D. K., J. M. Thomas, J. R. Decker and J. F. Park Alveolar deposition of $23{ }^{39} \mathrm{PuO}_{2}$ aerosols in beagle dogs as a

72-CRD function of respiration and aerosol parameters

Health Phys. 22, 845-855 (1972) NSA 26, 38798

CRAIG, D. K., R. L. Buschbom and J. P. Herring Relationships between nebulizer suspension concentration, concentration and size distribution of $239 \mathrm{PuO}_{2}$ aerosols generated for animal inhalation experiments

Health Phys. 24, 637-644 (1973) NSA 28, 8514

CRAIG, D. K., D. D. Mahlum and E. L. Klepper Relative quantity of airborne plutonium deposited in the respiratory tract and on the skin of rats

Health Phys. 27, 475-479 (1974) NSA 31, 16904

CRAIG, D. K., and R. L. Buschbom

The alveolar deposition of inhaled plutonium aerosols in rodents

$71-\mathrm{COR}$

Amer. Ind. Hyg. Ass. J. 36, 172-180 (1975) NSA 31, 33555

CRAIG, D. K. See also: 74-PAR

CRANDALL, J.L.

Applications of transplutonium elements

Doc. DP-MS-71-52, 31 p. (1971) NSA 28, 27578

CRANE, W. W. T.

Future of the actinide elements

Atompraxis $6,12-15$ (1960) NSA 14, 8330

CROOK, G. H. See: 68-LAR

CROSS, F. T., and J. C. Sheppard

In-phantom dosimetry of $238 \mathrm{Pu}$ circulatory support heat sources

Nucl. Technol. 13(1), 83-94 (1972) NSA 26, 9544 
CROWLEY, J., H. Lanz, K. Scott and J. G. Hamilton

46-CRJ A comparison of the metabolism of plutonium $\left(\mathrm{Pu}^{238}\right)$ in man and the rat

Doc. $\mathrm{CH}-3589,15$ p. (1946)

CROWLEY, J. F. See also: 46-LAH, 46-SCK-2, 48-SCK, 49-SCK

CUMMINGS, S. L., and L. Bankert

Uptake of $1{ }^{44} \mathrm{Ce}, 147 \mathrm{Pm}$, and $238 \mathrm{Pu}$ by oat plants from soils

Radio1. Health Data Rep. 12(2), 83-85 (1971) NSA 25, 42260

71-CLIM 
DAGLE, G. E.

73-DAG

Lymph node clearance of plutonium from subcutaneous wounds in beagles

Thesis, Colorado State University, Doc. C00-1787-18, 127 p.

(1973) NSA 29, 13042

DAGLE, G. E., R. D. Phemister, J. L. Lebe T, R. Jaenke and

75-DAG

R. L. Watters

Plutonium induced popliteal lymphadenitis in beagles

Radiat. Res. $61,239-250$ (1975) NSA 31, 20090

DAGLE, G. E., J. L. Lebel, R. D. Phemister, R. L. Watters and

$75-D A G-2$

L. S. Gomez

Translocation kinetics of plutonium oxide from the popliteal

lymph nodes of beagles

Health Phys. 28, 395-398 (1975) NSA 32, 3829

DAGLE, G. E. See also: 74-GOM, 74-SAN-2

DANPURE, C. J., and D. M. Tayior

Effect of internally deposited plutonium-239 on the lysosomes

74-DAN of rat liver

Radiat. Res. 59, 679-692 (1974) NSA 30, 29782

DANPURE, C. J. See a 1so: 70-BOC, 71-P0L, 69-TAY-3

DAS, G. C. See: 74-MAD

DAVIDSON, R. S. See: 71-RUA

DAVIES, C. N. (ed.)

Inhaled Particles and Vapours, Pergamon Press, London (1961)

NSA 16,5125

DAVIES, H. See: 67-MOP

DAVIES, S, See: 72-WHA

DAVIS, J. J

Radioactive materials in aquatic and terrestrial organisms exposed to reactor effluent water

Proc. Int. Conf. Peaceful Uses At. Energy, 2nd, 1958, 18,

423-428 (1958) NSA 12, 14516

DAVIS, J. J. See also: 72-ROM

DE BORTOLI, M., P. Gaglione, A. Malvicini and E. Van Der Stricht $239,238 \mathrm{Pu},{ }^{90} \mathrm{Sr}$, and ${ }^{137} \mathrm{Cs}$ in surface air from mid 1961 through 1965

In: Proceedings of the 1st International Congress of Radiation

Protection (W. S. Snyder, et al., eds., Pergamon Press, 0xford)

$361-367$ (1968) NSA 23, 11661

DE BORTOLI, M. C., and P. Gaglione SNAP ${ }^{238} \mathrm{Pu}$ fallout at Ispra, Italy

Health Phys. 16, 197-204 (1969) NSA 23, 9573

DE BORTOLI, M. C., and P. Gaglione

Natural and fallout radioactivity in the soil

Health Phys. 17, 701-710 (1969) NSA 24, 4379

DE BRUYN, P. P. H.

61-DAV

Lymph node and intestinal lymphatic tissue

In: Histopathology of Irradiation from External and Internal

Sources (W. Bloom, ed., McGraw-Hi11, New York) 348-445 (1948) 
DE RAS, E. M. M. See: 71-VAN, 71-VAN-2

DEAN, F. K., S. C. Bushong, N. Prasad and S. Briney

Relative biological effectiveness of ${ }^{252} \mathrm{Cf}$ on acute mammalian lethality

Radiology 104, 699-703 (1972) NSA 26, 53484

DEAN, P. N., and W. H. Langham

Tumorigenicity of small highly radioactive particles

69-DEA Health Phys. 16, 79-84 (1969) NSA 23, 8080

DEAN, P. N., D. Ramsden and J. Rundo Comment on effective transmission of the human thorax for photons from $239 \mathrm{Pu}, 241 \mathrm{Am}$ and other low-energy emitters Health Phys. 19, $312(1970)$

DEAN, P. N. See also: 72-J0L

DECKER, J. R. See: 72-CRD

DEEL, B. L. See: 72-EDL

DELANEY, H. See: 45-RUE

DELL, R. B. See: 72-JEW-2, 72-TAG

DELLA ROSA, R. J. See: 71-STA

DELLE SITE, A. See: 73-TES

DENHAM, D. H.

Heal th physics considerations in processing transplutonium elements

Health Phys. 16, 475-487 (1969) NSA 23, 17527

DEVILLERS, C. See: 71-BER

DICK, J. L. See: 58-BAK

DILLEY, J. V. Origin of urinary taurine excretion during chronic radiation injury

Radiat. Res. 50, 191-196 (1972) NSA 26, 33803

DILLEY, J. V. See also: 71-PAR

DILLMAN, L. T., and T. D. Jones

Internal dosimetry of spontaneously fissioning nuclides

Hea1th Phys. 29, 111-123 (1975)

DIONNE, P. J. See: 70-STU

DIX, G. P., and T. J. Dobry

Critical parameters in plutonium safety evaluations

Hea 1 th Phys. 22, 569-574 (1972) NSA 26, 38420

DOBROSKOK, A. 1. See: 74-LIK

DOBRY, T. J. See: 72-DIX

DOBSON, R. L.

Americium poisoning

In: Therapy of Radioelement Poisoning (M. W. Rosenthal, ed., Doc. ANL-5584) 28-35 (1956) EP S2, 198

DOCKUM, J. G. See: 75-LOR 
DOCKUM, N. L., and A. C. Case

$56-\mathrm{DOC}$

Autoradiographic analysis of plutonium deposition in human skin Doc. HW-44922 (1956)

DOCKUM, N. L, E. J. Coleman and G. Vogt Detection of plutonium contamination in humans by the autoradiographic method

Stain Technol. 33, 137-142 (1958) NSA 12, 10345

DOCKUM, N. L., and A. C. Case

Autoradiographic analysis of plutonium deposition in human skin

Acta Radiol. 50, 561-564 (1958) BA 33, 28523

DOCKUM, N. L., G. S. Vogt and E. J. Coleman

Applications of autoradiography in biological research

J. Biol. Photo. Assoc. 27, 1-18 (1959) NSA 13, 18830

DOCKUM, N. L. See also: 56-GE0, 57-GE0, 69-JEW, 58-KAW, 62-MCR-2, 69-TAG-3

DOLGIREV, E. I., G. N. Kaidanovskii and V. P. Shamov

In vivo counting of transuranium isotopes in the human body:

$239 \mathrm{Pu}$ and $241 \mathrm{Am}$

In: Health Physics Problems of Internal Contamination (E. Bujdoso,

ed., Akademiai Kiado, Budapest) 497-502 (1973) NSA 28, 30308

DOLGIREV, E., G. N. Kaidanovskii, N. V. Porozov and V. P. Shamov The methods of absolute calibration of equipment for measurements of $\mathrm{Pb}-210, \mathrm{Pu}-239$ and Am-241 in human body

In: Proc. Third Int. Cong. Int. Radiat. Prot. Assn. (W. S.

Snyder, ed., Doc. CONF-730901-P2) Vol. 2, 969-975 (1974)

NSA 30,26844

DOLGIREV, E. I., G. N. Kaidanovskii, T. M. Likhtareva and N. V.

Porozov

Changes of $241 \mathrm{Am}$ content in four persons (in Russian)

Med. Radiol. 19(10), 72-74 (1974) NSA 31, 878

DOLGIREV, E. I. See also: 74-ZAP

DOLPHIN, G.W.

Estimation of body content following inhalation of insoluble plutonium

In: Assessment of Radioactivity in Man, Vol. 2 (International

Atomic Energy Agency, Vienna) 589-602 (1964) NSA 18, 33260

DOLPHIN, G. W.

Biological problems in the radiological protection of workers exposed to plutonium-239

Health Phys. 20, 549-557 (1971) NSA 25, 42488

DOLPHIN, G. W.

Problems associated with setting safe levels for working with plutonium

Health Phys. $\underline{22}, 937-942$ (1972) NSA $\underline{26}, 38757$

DOLPHIN, G.W.

Some problems in interpretation of bioassay data

In: Assessment of Radioactive Contamination in Man (International

Atomic Energy Agency, Vienna) 425-435 (1972) NSA 26, 56532

64-DOL

71-DOL

72-DOL

$72-\mathrm{DOL}-2$ 
DOLPHIN, G. W.

Maximum permissible concentrations and maximum permissible body

73-DOL burdens for transplutonic elements

In: Uranium-Plutonium-Transplutonic Elements (H. C. Hodge,

J. N. Stannard and J. B. Hursh, eds., Springer-Verlag,

New York) 897-908 (1973) PD $\underline{8}, 122 T$

DOLPHIN, G. W.

Hot particles

Radiol. Prot. Bu11. 1974(8), 8-10 (1974) NSA 31, 3748

DOLPHIN, G. W. See also: 70-BAI-5, 64-BEA, 66-BEA, 70-HOL, 66-JAC, 74-SCG, 74-SCG-2

DOSHCHENKO, V. N. See: 72-BUL, 72-KAL-3

DOTY, S. B., C. W. Yates, W. E. Lotz, W. Kisieleski and R. V.

$65-\mathrm{DOS}$

Talmage

Effect of short-term alpha irradiation on parathyroid activity and osteoclast numbers

Proc. Soc. Expt1. Biol. Med. 119, 77-81 (1965) NSá 19, 28065

DOUGHERTY, J. H., J. Z. Bowers, R. C. Bay and P. Keyanonda

Comparison of hematologic effects of internally deposited

radium and plutonium in dogs

Radiology 65, 253-259 (1955) NSA $\underline{9}, 6843$ EP $\underline{\text { S3}}, 442$

DOUGHERTY, J. H.

Some hematological responses to internal irradiation in the beagle

In: Some Aspects of Internal Irradiation ( $T$. $F$. Dougherty, et a)., eds., Pergamon Press, Oxford) 79-93 (1962) NSA 17, 19888

DOUGHERTY, J. H., and L. S. Rosenblatt

Leukocyte depression in beagles injected with ${ }^{226} \mathrm{Ra}$ or ${ }^{239} \mathrm{Pu}$

In: Delayed Effect of Bone-Seeking Radionuclides (C. W. Mays,

et al., eds., Univ. of Utah Press, Salt Lake City) 457-470 (1969)

NSA 23, 38796

DOUGHERTY, J. H., and L. S. Rosenblatt

Comparative toxicity of $226 \mathrm{Ra}, 239 \mathrm{Pu}, 228 \mathrm{Th},{ }^{228} \mathrm{Ra}$, and ${ }^{90} \mathrm{Sr}$

to leukocytes of beagles

Radiat. Res. 43, 56-70 (1970) NSA 24, 39572

DOUGHERTY, J. H., and L. S. Rosenblatt

Long-term hematological effects of internal emitters in beagles

Radiat. Res. 48, $319-331$ (1971) NSA 26, 12211

DOUGHERTY, J. H.

Hematologic changes induced by $23{ }^{9} \mathrm{Pu}$ in beagles

In: Radiobiology of Plutonium (B. J. Stover and W. S. S. Jee, eds.,

J. W. Press, Salt Lake City) 75-856 (1972) NSA 26, 41255

DOUGHERTY, J. H. See also: 62-D0T, 69-MAY, 69-TAG

DOUGHERTY, T. F., B. J. Stover, J. H. Dougherty, W. S. S. Jee,

C. W. Mays, C. E. Rehfield, W. R. Christensen and H. C. Goldthorpe Studies of the biological effects of $\operatorname{Ra}^{226}, \mathrm{Pu}^{239}, \mathrm{Ra}^{228}\left(\mathrm{Ms}_{\mathrm{S}} \mathrm{h}_{1}\right)$, $\mathrm{Th}^{228}(\mathrm{RdTh})$, and $\mathrm{Sr}^{90}$ in adult beagles

Radiat. Res. 17, 625-681 (1962) NSA 16, 32705

DOUGHERTY, T. F.

Study of the long term biological effects of internal irradiation in adult beagles

In: Some Aspects of Internal Irradiation ( $T$. F. Dougherty, et al., eds., Pergamon Press, 0xford) 3-6 (1962) NSA 17, 19883 
DOUGHERTY, T. F.

Incidence of bone cancer in internally irradiated dogs

$62-D 0 T-3$

In: Some Aspects of Internal Irradiation (T. F. Dougherty, et al.,

eds., Pergamon Press, 0xford) 47-61 (1962) NSA 17, 19886

DOUGHERTY, T. F., and C. W. Mays

Bone cancer induced by internally deposited emitters in beagles

In: Radiation-Induced Cancer (International Atomic Energy Agency,

Vienna) 361-367 (1969) NSA 24, 34031

DOUGHERTY, T. F. See a 7 So: 62-BED, 69-MAY, 70-MAY, 72-MAY-2, 69-TAG, 71-TAG

DOW Chemical Co.

Evaluation and treatment of an acute internal exposure to plutonium

Doc. RFP-446, 29 p. (1965) NSA 19, 26579

DOW Chemical Co.

Proceedings of the Rocky Flats Symposium on Safety in Plutonium Handling Facilities

Doc. CONF-710401, 457 p. (1972)

DRENT, $W$. , and $W$. Hunzinger

Application of transuranium elements and related safety aspects

In: Radiation Protection Problems Relating to Transuranium Elements

(Doc. EUR-4612) 99-113 (1971) NSA 25, 37815

DREW, R. M., R. G. Fairchild and H. L. Atkins

Oxygen enhancement ratio as measured with HeLa cells and protracted irradiation from ${ }^{252} \mathrm{Cf}$ and ${ }^{137} \mathrm{Cs}$

Radiology 104, 409-413 (1972) NSA 26, 50818

DREW, R. M. See also: 73-ATK, 69-FAI, 70-FAI, 70-FAI-2, 73-FAI

DROPP0, J. G. See: 73-SEL

DUCousso, R., J. C. Nenot, C. Pasquier and J. Lafuma

72-DUC

Surgical treatment of wounds contaminated by radioactive substances About six cases related in the literature (in French)

Doc. CEA-BIB-203, 37 p. (1972) NSA 26, 59131

DuCousso, R., J. C. Nenot and C. Pasquier Internal radio-contamination therapy. Present aspects and future prospects (in French)

Radioprotection $\underline{9}(1), 27-39$ (1974) NSA 31,14426

DULCINO, J., J. Colard, D. Nuttinck, J. Luysterborg and G. Koch Immediate and long-term measures taken in following the contamination of personnel by ${ }^{241} \mathrm{Am}$ and ${ }^{242} \mathrm{Cm}$

In: Radiation Protection Problems Relating to Transuranium

Elements (Doc. EUR-4612) 631-646 (1971) NSA 25, 37804

DUNCAN, K. P.

Some aspects of the prevention and treatment of excessive internal radioactive contamination

Brit. J. Radiol. 37, 120-123 (1964) NSA 18, 11891

DUNCAN, K. P. See also: 66-BEA

DUNN, L. See: 71-BLI 
DUNSTER, H. K.

56-DUH

The discharge of radioactive waste products into the Irish Sea.

Part 2. The preliminary estimate of the safe daily discharge of radioactive effluent

In: Proceedings of the International Conference on the Peaceful Uses

of Atomic Energy, Vol. 9 (United Nations, Geneva) 712-715 (1956)

EP S2, 195

DUNSTER, H. J. See also: 66-BEA, 70-HOL

DURAKOVIC, A. B., J. G. Hollins and M. C. Storr The influence of age and sex on the metabolism of americium by rats

Health Phys. 24, 541-546 (1973) NSA 28, 2999

DURAKOVIC, A. B. See also: 72-HOG, 73-HOG, 74-HOG

DURBIN, $P$.

Metabolic characteristics within a chemical family

60-DUR

Health Phys. 2, 225-238 (1960) NSA 14, 10699

DURBIN, P. W., M. H. Williams and N. Jeung

Metabolism of $24 \mathrm{Am}$ in the monkey (Abstract)

Radiat. Res. 14, 462 (1961)

DURBIN, P. W.

Distribution of the transuranic elements in mammals

73-DUA

Health Phys. 8, 665-671 (1962)

NSA 17, 10324

DURBIN, P. W., N. Jeung and M. H. Williams

Dynamics of $24^{4} \mathrm{Am}$ in the skeleton of the rat: A study of the

69-DUR relationship between behavior of bone-seeking elements and bone growth status

In: Delayed Effects of Bone-Seeking Radionuclides (C. W. Mays, et a1., eds., Univ. of Utah Press, Salt Lake City) 137-156 (1969)

NSA 23, 38421

DURBIN, P. W.

Plutonium in man: A twenty-five year review

Doc. UCRL-20850, 141 p. (1971) NSA 26, 15527

DURBIN, P. W., M. W. Horovitz and E. R. Close

Plutonium deposition kinetics in the rat

Health Phys. 22, 731-741 (1972) NSA 26, 38787

DURBIN, P. W.

Plutonium in man: A new look at the old data

In: Radiobiology of Plutonium (B. J. Stover and W. S. S. Jee,

eds., J. W. Press, Salt Lake City) 469-530 (1972)

NSA 26, 41270

DURBIN, P. W

Metabolism and biological effects of the transplutonium elements

In: Uranium-Plutonium-Transplutonic Elements (H. C. Hodge,

J. N. Stannard and J. B. Hursh, eds., Springer-Verlag, New York) $739-896$ (1973) NSA 29, 27140

DURBIN, P.

Behavior of plutonium in animals and man

61 -DUR

62-DUR

In: Plutonium Information Meeting for an Ad Hoc Subcommittee

of the Advisory Committee on Rector Safeguards, Doc. CONF-740115, $30-55$ (1974) NSA 31, 14412

DURBIN, P. W. See also: 74-GAV

DYMOND, B. See: 64-SMH 
EAGLE, M. C. See: 72-NED, 72-NED-2

EAGLE, R. J. See: 74-NOS-2

EAKINS, J. D., and A. Morgan

64-EAK

The role of faecal analys is in a bioassay program

In: Assessment of Radioactivity in Man, Vol. 1 (International

Atomic Energy Agency, Vienna) 23i-244 (1964) NSA 18, 33266

EASTON, C. R. See: 68-ANO

EBEL, H. See: 75-PLA

EDLING, D. A., L. G. Musen and B. L. Deel

Health Physics aspects of working with ${ }^{238} \mathrm{PuO}_{2}$ microspheres

$72-E D L$

In: Heal th Physics Operational Monitoring, Vol. 1 (C. A.

Willis, ed., Gordon and Breach, New York) 449-470 (1972)

NSA 29, 30201

EDLING, D. A., and H. F. Anderson

Differences in applied health physics problems and procedures between ${ }^{238} \mathrm{Pu}$ and ${ }^{239} \mathrm{Pu}$

In: Health Physics Operational Monitoring, Vol. 1 (C. A. Willis, ed., Gordon and Breach, New York) 471-486 (1972) NSA 29, 30202

EDWARDS, R. See: 45-RUE

EGOROVA, T. M. See: 69-MOS-4

EHRET, R., H. Kiefer, R. Maushart and G. Moehrle Performance of an arrangement of several large-area proportional counters for the assessment of $239 \mathrm{Pu}$ lung burdens

In: Assessment of Radioactivity in Man, Vol. I (International

Atomic Energy Agency, Vienna) 141-149 (1964) NSA 19, 30584

EISENBUD, $M$.

Environmental Radioactivity, 2nd. Ed., Academic Press,

New York, 542 p. (1973) NSA 28, 27245

EL-ASSALY, F. M. See: 72-MOQ

ELDER, J. C., M. Gonzales and H. J. Ettinger

Plutonium aerosol size characteristics

Health Phys. 27, 45-53 (1974) NSA 30, 15423

ELKINA, N. I., and I. A. Tseveleva

Mineral and protein metabolism in bone tissues of rats in plutonium injury

Med. Radiol. 6(3), 58-63 (1961) translated in JPRS-11242, 126-134

NSA $\underline{16}, 5175$

ELKINA, N. I., and I. A. Tseveleva

Mineral and protein metabolism in bone tissue of plutoniuminjured rats

In: Plutonium-239: Its Distribution, Biological Effect and

Accelerated El imination (A. V. Lebedinskii and Y. I. Moskalev, eds., Medgiz, Moscow) 56-62 (1962) translated in FTD-TT-63-559, 77-87 NSA 17,30250

ELKINA, N. I.

Blood serum proteins in plutonium injured dogs and rabbits

64-EHR

$72-E D L-2$

Radiobiologiya 2, 834-837 (1962) translated in AEC-tr-5433,

48-53 NSA $\underline{17}, 15741$ EP $\underline{5}, 64$

$62-E L K-2$ 
ELKINA, N. I., and Z. B. Tokarskaya

63-ELK

The problem of 1 iver pathochemistry after injury with plutonium-239

Vopr. Med. Khim 9, 154-160 (1963) translated in JPRS-19995, 1-9, and in Fed. Proc. Trans1. Supp1. 23, T533-T535

INSA 17, 28701; 18, 29209

ELKINA, N. I.

Effect of $\mathrm{Pu}^{239}$ on phosphatase activity and on $\mathrm{Ca}, \mathrm{P}$, and $\mathrm{N}$

63-ELK-2 contents of bone tissue in rabbits

Radiobiologiya $3,351-354$ (1963) translated in AEC-tr-5436,

32-36 NSA 17,31926

ELKINA, N. I.

Calcium and phosphorous metabolism in rabbit bone under the effect of $239 \mathrm{Pu}$

Radiobiologiya 7, 42-46 (1967) translated in AEC-tr-6886, 63-72

NSA 21, 34593

ELKINA, N. I., and R. E. Libinzon

Activity of alkaline and acid phosphatase in the bone tissue of rabbits affected with plutonium-239 (in Russian)

vop. Med. Khim. 13, 591-597 (1967) NSA 22, 23454

ELKINA, N. I.

Metabolic processes in the bone tissue of animals damaged by $239 \mathrm{Pu}$

In: Remote Aftereffects of Radiation Damage (Y. I. Moskalev, ed., Atomizdat, Moscow) 372-380 (1971) translated in AEC-tr-7387, $406-415$ EP S3, 309

ELKINA, N. I. See a1so: 62-BEL, 62-BEL-2, 66-LIB

ELLIS, L. C., and D. L. Berliner The effects of ionizing radiations on endocrine cells. VI. Alterations in androgen biosynthesis by canine testicular tissue after the internal deposition of some radionuclides

Radiat. Res. $32,520-537$ (1968) NSA 22, 43244

EMERY, R. M., D. C. Klopfer and W. C. Weimer The ecological behavior of plutonium and americium in a fresh water ecosystem: Phase I. Limnological characterization and isotope distribution

Doc. BNWL-1867, 76 p. (1974) NSA 31, 5987

EMERY, R. M., and T. R. Garland Ecological behavior of plutonium and americium in a freshwater ecosystem. Phase II. Implications of differences in transuranic isotope ratios

Doc. BNWL-1879, 29 p. (1974) NSA 31, 25779

ENGLISH, S. G. See: 45-HEM

ENGSTROM, A. See: 62-ULB

ENOMOTO, Y., and 0. Matsuoka

A study of plutonium excretion into bile and its acceleration by cholagogues

In: Final Report of Research Project on Plutonium Hazards, April 1966 - March 1970 (M. Suzuki et al., eds., Doc. NIRS-Pu-8)

33-35 (1971) PD $\underline{6}, 1573$ EP S1, 523

ENVIRONMENTAL Plutonium Data Base Group

Environmental Aspects of Plutonium - A Selected, Annotated bibl iography

Doc. ORNL-EIS-72-21, 387 p. (1972) NSA 27, 7561 
ENVIRONMENTAL. Pl utonium Data Base Group

73-ENV

Environmental aspects of plutonium and other elements - A selected, annotated bibliography

Doc. ORNL-EIS-73-2l (Suppl. 1) 482 p. (1973) NSA 28, 21068

ENVIRONMENTAL Plutonium Data Base Group

74-ENV

Environmental aspects of plutonium and other elements - A selected, annotated bibliography

Doc. ORNL-EIS-74-21 (Supp1. 2) 272 p. (1974) NSA 29, 24191

ENVIRONMENTAL Plutonium Data Base Group (Applied Ecology Information Center)

Environmental aspects of the transuranics. A selected annotated bibl iography

Doc. ORNL-EIS-74-31 (Supp1. 3), 226 p. (1974) NSA 31, 5969

ENVIRONMENTAL Plutonium Data Base Group (Applied Ecology

Information Center)

Environmental Aspects of the Transuranics. A selected annotated bibl iography

Doc. ORNL-EIS-75-21-No. 5, 226 p. (1975) NSA 32, 14289

ENVIRONMENTAL Plutonium Data Base Group (Applied Ecology

Information Center)

Environmental Aspects of the Transuranics. A Selected Annotated Bibliography

Doc. ORNL-EIS-75-21-No. 6, 226 p. (1975) NSA 32, 24339

EPSTEIN, R. J., and E.W. Johanson

Apparatus for monitoring $239 \mathrm{Pu}$ in wounds

Health Phys. 12, 29-35 (1966) NSA 20, 9269

ERDMAN, H. E.

Effects of ingested Pu-239 on fecundity, fertility and life span

of habrobracon (hymenoptera-braconidae)

Health Phys. 8, 635-638 (1962) NSA 17, 13918

ERDMAN, R. C. See: 74-MOA

ERLEKSOVA, E. V.

Distribution of Radioactive Elements in the Animal Organism

(210Po, $239 \mathrm{Pu}$ and ${ }^{90} \mathrm{Sr}$ ). Atlas., Medgiz, Moscow (1960)

translated in AEC-tr-6982 (1969) NSA 23, 45603

EROKHIN, R. A., N. A. Koshurnikova, E. R. Lyubchanskii, A. P. Nifatov and G. N. Reshetov

Content and microdistribution of plutonium-239 in rat lung and

liver and morphological changes in these organs after intratracheal

administration of the isotope

In: Distribution, Biological Effects, and Rapid Excretion of

Radioactive Isotopes (Y. I. Moskalev, ed., Meditsina, Moscow)

42-61 (1964) translated in AEC-tr-7590, 42-62 NSA 19, 40317

EROKHIN, R. A., N. A. Koshurnikova, V. K. Lemberg, E. R.

$66-$ ERO

Lyubchanskii and G. N. Reshetov

Content and microdistribution of $239 \mathrm{pu}$ and morphological changes in

the lungs of rats intratracheally administered this isotope

In: Distribution and Biological Effects of Radioactive Isotopes

(Y. I. Moskalev, ed., Atomizdat, Moscow) 96-103 (1966) translated

in AEC-tr-6944, 122-130 NSA 23, 22165

EROKHIN, R. A., N. A. Koshurnikova, V. K. Lemberg, A. P. Nifatov and A. A. Puzyrev

Pulmonary tumors in rats following intratracheal introduction of soluble $239 \mathrm{Pu}$ compounds (in Russian)

Gig. Tr. Prof. Zabol. 13(5), 61-63 (1969) PD 4, 3266 
EROKHIN, R. A., N. A. Koshurnikova, V. K. Lemberg, A. P. Nifatov

and A. A. Puzyrev

Some remote aftereffects of intratreacheal administration of chemically soluble $239 \mathrm{Pu}$ compounds

In: Remote Aftereffects of Radiation Damage (Y. I. Moskalev, ed., Atomizdat, Moscow) 315-333 (1971) translated in AEC-tr-7387, 344-363 PD 7, 2070

EROKHIN, R. A. See also: 68-BUIK, 68-BUL-2, 71-BUL-3, 71-BUL-4, 71-KOS-2, 72-KOS-2, 71-LEV-2, 61-RYS, 62-RYS, 74-TEA, 69-TSE

ERSHOV, E. B., D. P. Osanov and V. A. Rakova Distribution of $239 \mathrm{Pu}$ in intact skin in its surface contamination (in Russian)

Med. Radiol. 15(12), 44-46 (1970) NSA 25, 35092

ERSHOV, E. B., D. P. Osanov and V. P. Shamov

Evaluation of radiation dangers during contamination of the skin with plutonium and americium (in Russian)

In: Radiation Protection, Environment, and the Population

(Staatliche Zentrale fur Strahlenschutz, Berlin, German

Democratic Republic) 50-54 (1974) NSA 31, 8948

ERSHOV, E. B. See also: 71-0SA, 71-0SA-3

ESTOURNEL, R. See: 70-ROD

ETOH, H.

Accidental injection into finger tip in preparation procedure of $239 \mathrm{pu}$ solution (in Japanese)

Hoken Butsuri 2, 116-120 (1967) NSA 22, 21552

ETTINGER, H. J., W. D. Moss and H. Busey

Characteristics of the aerosol produced from burning sodium and plutonium

Nucl. Sci. Eng. 30, 1-13 (1967) NSA 21, 44882

ETTINGER, H. J., W. D. Moss and L. J. Johnson

Size selective sampling for $238 \mathrm{Pu}$

Health Phys. 23, 41-46 (1972) NSA 26, 50592

ETTINGER, H. J. See also: 74-ELD

EUSTLER, B. C. See: 58-FOR

EVANS, F. G. See: 62-TAD

EVANS, R. D.

Remarks on the maximum permissible deposition of plutonium in

62-EVA man, and the safety factors in the pivot point radiation protection guide of $0.1 \mu \mathrm{Ci}$ of radium in man

Health Phys. $8,751-752$ (1962) NSA 17, 10337

EVANS, R. D.

The effect of skeletally deposited alpha-ray emitters in man

Brit. J. Radiol. 39, 881-895 (1966) NSA 21, 8994

EVANS, R. D., A. T. Keane and M. M. Shanahan

Radiogenic effects in man of long-term skeletal alpha-irradiation

In: Radiobiology of Plutonium (B. J. Stover and W. S. S. Jee, eds.,

J. W. Press, Salt Lake City) 431-468 (1972) NSA 26, 41232 
EVE, I. S.

64-EVI

An outline of the metabolism of inhaled and ingested insoluble radionuclides

Brit. J. Radiol. 37, 115-120 (1964) NSA 18, 11589

EYRING, H. See: 70-STB-2, 72-STB-4 
FABRIKANT, J. I., and C. L. D. Smith

Radiographic changes following the administration of bone-seeking

$64-F A B$ radionuclides

Brit. J. Radio1. 37, 53-62 (1964) NSA 18, 9848

FABRIKANT, J. I., T. H. S. Hsu, D. H, Knudson and C. L. D. Smith Effect of LET on radiation carcinogenesis: Comparison of single and fractionated doses of $239 \mathrm{Pu}, 241 \mathrm{Am}, 32 \mathrm{p}$, and $X$-rays on the production of osteosarcomas in rats

In: Radionuclide Carcinogenes is (C. L. Sanders, et al., eds., Doc. CONF-720505) 322-346 (1973) NSA 28, 18561

FAIR, D. R. R., and A. S. McLean The disposal of waste products in the sea. Part 3 . The experimental discharge of radioactive effluents

In: Proceedings of the International Conference on the Peaceful

Uses of Atomic Energy, Vol. 9 (United Nations, Geneva) 716-717

(1956) EP $\underline{\mathrm{S}}, 193$

FAIRCHILD, R. G., R. M. Drew and H. L. Atkins

The relative biological effect of $252 \mathrm{Cf}$ radiation on HeLa cells in culture

Radiology 93, 1187-1189 (1969) NSA 24, 12220

FAIRCHILD, R. G., R. M. Drew and H. L. Atkins Dose-rate effects for various dose rates of ${ }^{252} \mathrm{Cf}$ radiation on HeLa cells in culture

Radiology 96, 171-174 (1970) NSA 24, 39546

FAIRCHILD, R. G., R. M. Drew and H. L. Atkins

Oxygen enhancement ratio for protracted irradiation with $252 \mathrm{Cf}$

Radiology 96, 661-665 (1970) NSA 25, 8704

FAIRCHILD, R. G., R. M. Drew, H. L. Atkins and J. S. Robertson

Oxygen enhancement ratio for cal ifornium- 252

In: Advances in Radiation Research. Biology and Medicine. Vol. II.

(J. F. Duplan, ed., Gordon and Breach, New York) 533-539 (1973)

NSA 31,26030

FAIRCHILD, R. G. See a1so: 70-ATK, 72-ATK, 73-ATK, 72-DRM, 70-HAZ

FARR, R. L. See: 68-0DL

FASISKA, B. C., D. E. Bohning, A. Brodsky and J. Horm

Urinary excretion of $241 \mathrm{Am}$ under DTPA therapy

Hea1th Phys. 21, 523-529 (1971) NSA 25, 55118

71-FAS

FEDOROV, C. A. See: 70-LEI

FEDOROVA, A. V. See: 73-SHU, 74-ZAP

FEDOROVA, M. N. See: 73-KRI

FELLOWS, M. H., L. Clark, Jr., J. J. O'Toole, D. B. Kimmel and

75-FEL

W. S. S. Jee

An improved technique for neutron-induced autoradiography of bone containing plutonium

Health Phys. $29,97-101$ (1975) NSA 32, 28325

FILATOV, V. V. See: 71-OSA-2, 73-0SA 
FILIPPOVA, L. G., and A. P. Nifatov

Pneumosclerosis and tumors of the lungs in rats after intratracheal

74-FIL administration of americium-241

Radiobiologiya 14, 366-368 (1974) translated in AEC-tr-7596,

58-61 NSA 31, 16845

FILIPPOVA, L. G., and A. P. Nifatov

Extrapulmonary tumors in rats after intratracheal administration

$74-F I L-2$ of americium-241

Radiobiologiya 14,793-796 (1974) translated in ERDA-tr-1, 183-

187 NSA 32, $6 \overrightarrow{798}$

FILIPPOVA, L. G. See a1so: 71-BUL-3, 72-BUL-3, 72-BUL-4, 74-MOS-3, $71-N I F-2,72-N I F-2$

FINK, R. M., and K. S. Cole

Radium-plutonium, polonium-plutonium ratios

In: Report of Conference on Plutonium (J. J. Nickson, ed.,

Doc. $\mathrm{CN}-3167$ ) 46-56 (1945) EP S3, 294

FINK, R. M. (ed.)

Biological Studies with Polonium, Radium and Plutonium, McGraw-Hill, New York, 411 p. (1950)

NSA 4,4188

FINK, R. M. See also: 50-BOY, 50-BOY-2

FINKEL, M. P.

The transmission of radiostrontium and plutonium from mother to offspring in laboratory animals

Physiol. Zool. 20, 405-421 (1947) NSA 30, 21409 EP S3, 433

FINKEL, M. P.

Absorption of ingested $\mathrm{Pu}$

In: Doc. $\mathrm{CH}-3782,44-49$ (1947) EP $\underline{6}, 39$

FINKEL, M. P.

Some further notes on the mice treated with plutonium before weaning

In: Doc. ANL-4078, 66-75 (1947) NSA 1, 40-H

FINKEL, M. P.

Relative biological effectiveness of radium and other alpha

emitters in CF No. 1 female mice

Proc. Soc. Expt1. Bio1. Med. 83, 494-498 (1953) NSA 8, 1802

FINKEL, M. P.

Relative biological effectiveness of internal emitters

$45-$ F IR

50-FIR

47-FIN

Radiology 67, 665-672 (1956) NSA 11, 869

FINKEL, M. P.

Late effects of internally deposited radioisotopes in laboratory animals

Radiat. Res. Supp1. 1, 265-279 (1959) NSA 13, 15906

FINKEL, M. P., B. 0. Biskis, R. J. Flynn, I. L. Greco and

$P$. Bergstrand-Jinkins

The toxicity of radioisotopes in dogs: status in quo

In: Doc. ANL-6464, 38-49 (1961) EP S2, 306

FINKEL, M. P., and B. 0. Biskis

Toxicity of plutonium in mice

Hea1th Phys. $8,565-579$ (1962) NSA 17, 10317

53-FIN

$56-$ FIN

59-FIN

$61-F I N$

$62-$ FIN 
FINKEL, M. P., and B. O. Biskis

$68-$ FIN

Experimental induction of osteosarcomas

Progr. Exp. Tumor Res. 10,72-111 (1968) NSA 23, 20405

FINKEL, M. P. See a1so: 47-BRM, 47-LIS, 50-SCH

FINKLE, R. D.

Distribution of injected plutonium

45-FID

In: Report of Conference on Plutonium (J. J. Nickson, ed.,

Doc. CN-3167) 5-9 (1945) EP S3, 288

FINKLE, R. D., R. H. Snyder, L. O. Jacobson, W. Kisieleski,

46-FID

B. Lawrence and E. L. Simons

The toxicity and metabolism of plutonium in laboratory animals

Doc. MDDC-1140 (CH-3783), 197 p. (1946) ADD 1, 1140

FINKLE, R. D. See also: 46-SNR, 46-SNR-2, 46-SNR-3

FINNEGAN, C. See: 55-FOR, 56-F0R, 57-FOR

FISH, B. R., R. L. Walker, G. W. Royster and J. L. Thompson

67-FIS Redispersion of settled particulates

In: Surface Contamination (B. R. Fish, ed., Pergamon Press, 0xford)

75-81 (1967) NSA 19, 24724 PD 2, 1684

FISH, B. R., G. W. Keilholtz, W. S. Snyder and C. D. Swisher Calculation of doses due to accidentally released plutonium from an LMFBR

Doc. ORNL-NSIC-74, 123 p. (1972) NSA 27, 4446

FISHER, H. See: 43-OVE, 46-SCK-2, 48-SCK

FISHER, W. See: 62-LOR, 62-TAG

FLEISCHER, R. L.

On the "dissolution" of respirable $\mathrm{PuO}_{2}$ particles

Health Phys. 29, 69-73 (1975) NSA 32, 28316

FLYGER, H. See: 70-GJ0

FLYNN, R. J. See: 61-FIN

FOLSOM, T. R., and V. F. Hodge

Early surveillance around coastal nuclear installations

In: Environmental Surveillance Around Nuclear Installations. Vol. I.

(International Atomic Energy Agency, Vienna) 289-299 (1974) NSA

31,14028

FOLSOM, T. R. See also: 73-HOV, 74-HOV, 74-HOV-2, 64-PIL, 71-WON-2, 72-WON

FORD, M. R. See: 68-SNY, 72-SNY-2

FOREMAN, H., and J. G. Hamilton

The use of chelating agents for accelerating excretion of

radioelements

Doc. UCRL-1351, or AECD-3247, 18 p. (1951) NSA 5, 6043

FOREMAN, H., M. Vier and M. Magee

The metabolism of $\mathrm{C}^{14}-1$ abeled ethylenediaminetetraacetic acid

in the rat

J. Bio1. Chem. 203, 1045-1053 (1953) BA 28, 13626

FOREMAN, H., P. A. Fuqua and W. D. Norwood

Experimental administration of ethylenediamine-tetraacetic acid

in plutonium poisoning

Arch. Ind. Hyg. Occup. Med. 10, 226-231 (1954) NSA 8, 5483 
FOREMAN, H., and T. T. Trujillo

$54-F 0 R-2$

Metabolism of $\mathrm{C}^{14}$ labeled ethylene diamine tetraacetic acid in human beings

J. Lab. C1 in. Med. 43, 566-571 (1954) BA 29, 1012

FOREMAN, H., T. T. Trujil10, O. Johnson and C. Finnegan

Ca EDTA and the excretion of plutonium

Proc. Soc. Expt1. Biol. Med. 89, 339-342 (1955) NSA $\underline{9}, 6172$

FOREMAN, H., C. Finnegan and C. C. Lushbaugh

Nephrotoxic hazard from uncontrolled edathemil calcium-disodium therapy

J. Am. Med. Assoc. 160, 1042-1046 (1956) EP S2, 210

FOREMAN, $H$.

Clinical experiences in removal of radioelements from the body

In: Therapy of Radiaelement Poisoning (M. W. Rosenthal, ed., Doc.

ANL-5584) 12-22 (1956) EP S3, 344

FOREMAN, H., J. Post and C. Finnegan

The effect of $x$-irradiation on the absorption of plutonium in the gastrointestinal tract

Radiat. Res. $\underline{7}, 267-269$ (1957) NSA 12,1177

FOREMAN, H., W. Moss and B. C. Eustler

Clinical experiences with radioactive materials

Am. J. Roentgeno1. Radium Therapy Nuclear Med. 79, 1071-1079

(1958) NSA 12,8955

FOREMAN, H., W. Moss and W. Langham

Plutonium accumulation from long-term occupational exposure

Health Phys. 2, 326-333 (1960) NSA 14, 18754

FOREMAN, H.

The application of chelating agents for hastening excretion of radioelements

In: Metal Binding in Medicine (M. J. Seven, ed., J. B. Lippincott, Philadelphia) 160-168 (1960) EP S2, 282

FOREMAN, $H$.

Studies on the mechanism of plutonium uptake by bone

55-FOR

$56-F O R$

Health Phys, 8, 713-716 (1962) NSA 17, 10331

FOREMAN, H.

Effect of DTPA on acceleration of excretion of actinide elements Health Phys. $8,735-737$ (1962) NSA 17, 10335

FOREMAN, $H$.

Medical management of radioactively contaminated wounds

In: Diagnosis and Treatment of Radioactive Poisoning (International

Atomic Energy Agency, Vienna) 387-411 (1963) NSA 17, 28640

FOREMAN, R. L. See: 74-HOV-2

FORKER, L. L. See: 46-ABR, 47-ABR

FOSTER, R. F.

Environmental behavior of chromium and neptunium

In: Radioecology (V. Schultz and A. W. Klement, Jr., eds., Reinhold, New York) 569-576 (1963) NSA 17, 33609 
FOWLER, E. B., J. R. Buchholz, C. W. Christenson, W. H. Adams,

68-FOW

E. R. Rodrigues, M. Celma, E. Iranzo and C. A. Ramis

Soils and plants as indicators of the effectiveness of a gross decontamination procedure

In: Radiological Protection of the Public in a Nuclear Mass

Disaster. Proceedings of a Symposium, Interlaken, Switzerland,

1968 (H. Brunner and 3. Pretre, eds., Fachverband fuer

Strahlenschutz) 456-459 (1968) NSA 23, 20201

FOWLER, E. B., R. W. Henderson and M. F. Milligan (eds.) Proceedings of Environmental Plutonium Symposium held at LASL, August $4-5,1971$

Doc. LASL-4756, 119 p. (1971)

FOWLER, E. B. See also: 70-ADM, 75-ADM, 71-BUJ

FOX, J. M. See: 68-ALK

FRADKIN, G. E., and V. F. Ushakova

Allalysis of the effectiveness of complexing agents which accelerate the elimination of radioactive isotopes from the body

In: Chemical Protection of the Body Against Ionizing Radiation (V. S. Balabukha, ed., Macmi11ian, New York) 147-162 (1963) NSA 18, 6611

FRADKIN, G. E. See also: 58-BAV

FRANCE, 0. See: 45-RUE

FRANCIS, C. W.

73-FRC

Plutonium mobility in soil and uptake in plants: A review

J. Environ. Qual. 2, 67-70 (1973) NSA 28, 384

FRASER, D. C.

Health physics problems associated with the production of experimental reactor fuels containing plutonium dioxide

Health Phys. 13, 1133-1143 (1967) NSA 21, 46971

FRASER, D. C. See a Iso: 70-RAM

FRENCH, E. See: 62-KRP

FRENKEL, A. See: 50-BOY

FRIED, J. F., E. H. Graul, J. Schubert and W. M. Westfall Superior chelating agents for the treatment of plutonium poisoning

Atompraxis 5, 1-5 (1959) NSA 13, 8556

FRIED, J. F. See also: 61-SCH-2

FRIEND, J. P.' (ed.)

The high altitude sampling program: Vol. 5. Supplementary HASP studies

Doc. DASA-1300 (Vol. 5), 313 p. (1961) NSA 16, 6644

EP S1, 49

FRY, F. A. See: 72-NED

FRYXELL, R. See: 47-CAR

FUJITA, M. See: 72-SHI, 73-SHI

FUKUMOT0, T. See: 67-MA0 
FUQUA, P. A.

Plutonium absorption - evaluation and treatment

Ind. Med. Surg. 34, 335-337 (1965) NSA 19, 36129

FUQUA, P. A. See also: 54-F0R, 72-NEL-2, 68-NEW, 56-NOR, 58-NOR, 69-NOR 
GAGE, A. A. See: 73-LAU

GAGL IONE, M. P. See: 68-DEB, 69-DEB, 69-DEB-2

GALLEGOS, A. F. See: 72-MCR-2

GANGULY, A. K. See: 70-BAI-5

GARLAND, T. R. See: 74-EMR-2, 74-WIE

GATROUSIS, C. See: 74-NOS, 74-NOS-2

GAVANKAR, H. G.

72-GAV

Risk and emergency radiation doses from plutonium dioxide

exposures (Thesis - Univ. of California, Berkeley)

Doc. TID-26142, 99 p. (1972) NSA 26, 53511

GAVANKAR, R., P. W. Durbin and T. H. Pigford

74-GAV

Basis for assessment of radiation risks for a hypothetical

release of plutonium dioxide from a fast reactor accident

In: Proceedings of the Fast Reactor Safety Meeting, Doc. CONF-

740401-P1, 498-513 (1974) NSA 31, 820

GEESAMAN, D. P.

Analysis of the carcinogenic risk from an insoluble alpha-

emitting aerosol deposited in deep respiratory tissue

Doc. UCRL-50387, 19 p. (1968) NSA 22, 33819

GEESAMAN, D. P.

An analysis of the carcinogenic risk from an insoluble alpha-

68-GES-2

emitting aerosol deposited in deep respiratory tissue: Addendum

Doc. UCRL-50387 (Add.) 11 p. (1968) NSA 23, 29826

GEIGER, E. L. and S. M. Sanders, Jr.

Acute uptake of plutonium and uranium following wound contamination

Proc. Health Phys. Soc. 61-66 (1957) NSA 12, 8288

GEORGE, D. L. See: 73-BEY

GEORGE, L. A., N. L. Dockum and L. K. Bustad

Decontamination of pig skin contaminated with a plutonium solution Doc. HW-44526, 14 p. (1956) NSA 12, 7672

GEORGE, L. A., Jr., N. L. Dockum and L. K. Bustad

68-GES

Removal of plutonium from pig skin

In: Doc. HW-47500, 146-156 (1957) EP S2, 223

GEORGE, L. A., Jr. See also: 62-BAI-3, 62-BAL, 62-BUS, 60-SUL, 56-WEK

GIBB, F. R. See: 67-MOP, 70-YUI

GILBERT, R. 0 . See: 73-ROM, 75-ROM

GILLETTE, R.

Radiation spill at Hanford: The anatomy of an accident

73-GIL

Science 181 728-730 (1973)

GILLETTE, R.

74-GIL

Plutonium and the "hot particle problem": Environment group

proposes a draconian answer

Science 183, 834-835 (1974) PD $\underline{8}, 3243$ 
GILLETTE, R.

74-GIL -2

Plutonium. (I): Questions of health in a new industry

Science 185, 1027-1032 (1974) NSA 30, 29773

GILLETTE, R.

$74-\mathrm{GIL}-3$

P1utonium (II): Watching and waiting for adverse effects

Science 185, 1140-1143 (1974) NSA 30, 29790

GIMBERT, J.L. See: 70-KUN-2

GJORUP, H. L., H. E. Busch, H. Flyger, J. Lippert, H. C. Rosenbaum,

70-GJ0

A. Aarkrog, H. Hansen, H. Kunzendorf, L. Lovborg, B. Skytte-Jensen and $E$. Sorensen

Investigation and evaluation of contamination levels [Thule incident] USAF Nuclear Safety 65, (Part 2) Spec. Edition AFRP 122-1, 57-63

$(1970)$

GLAUBERMANN, H., W. R. Bootmann and A. J. Breslin

Studies of the significance of surface contamination

67-GLA

In: Surface Contamination (B. R. Fish, ed., Pergamon Press, 0xford) 169-

178 (1967) NSA 22, 23546 PD 2, 1686

GLENN, D. W. See: 71-WIT

GNEUSHEVA, G. I.

Uptake of $239 \mathrm{Pu}$ into agricultural plants from soi (in Russian)

71-GNE

Biol. Nauki 14(8), 60-63 (1971) PD 7, 2081

GNEUSHEVA, G. I., M. M Saurov, T. F. Voronina and G. P. Novoselova Quantitative features of transfer of $239 \mathrm{Pu}$ from water into soil (in Russian)

Biol. Nauki 14(10), 54-56 (1971) PD 7, 2082

GOFMAN, J. W.

Cancer Hazard from Inhaled Plutonium, Committee for Nuclear

Responsibility, Dublin, California, 33 p. (1975)

GOFMAN, J.W.

Estimated Production of Human Lung Cancers by Plutonium from Worldwide Fallout, Committee for Nuclear Responsibility, Dublin, California, 35 p. (1975)

GOLDEN, P. A. See 70-MAE

GOLDMAN, M. See: 72-BUS

GOLDTHORPE, H. C.

Effect of aging and internal irradiation on blood chemistry

$62-\mathrm{GOL}$

In: Some Aspects of Internal Irradiation (T. F. Dougherty, et a1., eds., Pergamon Press, Oxford) 117-129 (1962) NSA 17, 19890

GOLDTHORPE, H. C. See also: 62-D0T

GOMEZ, L. S., J. L. Lebel and R. L. Watters

Effect of Iymph node removal on $\mathrm{PuO}_{2}$ translocation

71-GNE-2

75-GOF

Health Phys. 22, 833-836 (1972) NSA 26, 38797

GOMEZ, L. S.

Lymph transport of $239 \mathrm{PuO}_{2}$ in dogs

Thesis, Colorado State University, Doc. C00-1787-17, 76 p. (1973)

PD 6,5006

GOMEZ, L. S., R. W. Bistline, G. E. Dagle, J. L. Lebel and R. L. Watters

Effect of delayed 1 ymphadenectomy on $239 \mathrm{PuO}_{2}$ translocation in dogs Hea1th Phys. 27, 213-215 (1974) NSA 30, 29820 
GOMEZ, L. S. See also: 75-DAG-2

GONGORA, G., R. Gongora and H. Jammet

Method for evaluating $241 \mathrm{Am}$ burdens in the lung

In: Assessment of Radioactive Contamination in Man (International

Atomic Energy Agency, Vienna) 623-633 (1972) NSA 26, 56538

GONGORA, R. See also: 72-GON, 64-PIJ

GONZALES, M. See: 74-ELD

GRAHAM, T. E.

Treatment of two plutonium cases with zirconium malate in England

56-GRA

In: Therapy of Radioelement Poisoning (M. W. Rosenthal, ed., Doc. ANL-

5548) 48-52 (1956) EP S2, 202

GRAUL, E. H. See: 59-FRI

GRECO, I. L. See: 67-FIN

GREENBERG, D. See: 46-ABR, 47-ABR

GREENE, D. See: 73-NIA

GREGORIDES DE LOS SANTOS, A. See: 70-ALV

GRIDGEMAN, N. T.

Methods of assay of the relative toxicity of certain bone-seeking

$71-G R I$ radionuclides

Radiat. Res. $\underline{48}, 291-302$ (1971) NSA 26, 12469

GRIFFIN, B. I. See: 67-SWI

GROMOV, V. V., V. I. Spitsyn and V. V. Surikov

Ultrafiltration studies of the state of plutonium and ruthenium in seawater (in Russian)

Radiokhimiya 16, 312-16 (1974) PD $\underline{8}, 3223$

GROMOV, V. V., and V.I. Spitsyn

Uptake of plutonium, ruthenium and technetium by phytoplankton

$72-\mathrm{GON}$

56-GRA

Dok1. Akad. Nauk SSSR 215, 214-217 (1974) translated in Dok1. Biol.

Sci. $215(1-6), 147-150$ (1974), al so as ORNL-tr-2907 NSA 31,8653

GROMOV, V. V., and V. I. Spitsyn

Influence of phytoplankton on the physicochemical state of

$23{ }^{9} \mathrm{Pu},{ }^{9} \mathrm{TC}$, and ${ }^{60} \mathrm{Co}$ in sea water

Dok1. Akad. Nauk SSSR 215, 451-453 (1974) translated in Dok1. Biol.

Sci. $215(1-6), 151-15 \frac{3}{3}(1974)$, also as ORNL-tr-2911 NSA 31,8654

GROULX, P. R. See: 69-MAG

GLIDIKSEN, P. H., and 0. D. T. Lynch, Jr.

75-GUD

Radioactivity levels in Eniwetok soil

Health Phys. 29, 17-25 (1975) NSA $\underline{32}, 27940$

GUILMETTE, R. A. See: 74-CON

GURNEY, M. E. See: 75-FOL

GUZAK, S. See: 67-LUS 
HACKETT, P. L.

53-HAC

Effect of repeated zirconium citrate injections on distribution of plutonium in the rat

Proc. Soc. Expt1. Biol. Med. $\underline{83}, 710-712$ (1953) BA 28, 5977

HACKETT, P. L. See a Tso: 60-SUL

HAGEN, C. W. See: 45-RJE

HAJEK, B. F.

Plutonium and americium mobility in soils

$66-H A J$

Doc. BNWL-CC-925 (1966) NSA 2l, 25971

HAKONSON, T. E., and L. J. Johnson Distribution of environmental plutonium in the Trinity Site ecosystem after 27 years

In: Proc. Third Int. Cong. Int. Radiat. Prot. Assn. (w. S. Snyder, ed., Doc. CONF-730901-P1) Vol. 1, 242-247 (1974) EP S3, 266

HAKONSON, T. E., L. J. Johnson and W. D. Purtymun Distribution of plutorium in liquid waste disposal areas at Los Alamos

In: Proc. Third Int. Cong. Int. Radiat. Prot. Assn. (W. S. Snyder, ed., Doc. CONF-730901-PI) Vol. 1, 248-253 (1974) EP $\underline{5}, 325$

HALE, V. Q., and A. Wallace Effect of chelates on uptake of some heavy metal radionuclides from soil by bush beans

Soil Sci. 109, 262-263 (1970) NSA 24, 25371

HALE, V. Q. See also: 69-WAC

HALL, E. J., and R. G. Fairchild Radiobiological measurement with californium-252

Brit. J. Radiol. 43, 263-266 (1970)

HALL, E. J., H. H. Rossi and L. A. Roizin Low-dose-rate irradiation of manmalian cells with radium and cal i fornium-252

Radiology 99, 445-451 (1971) NSA 25, 37809

HALL, E. J. $A$ determination of the oxygen enhancement ratio for ${ }^{252} \mathrm{Cf}$ using cultured mammalian cells

Brit. J. Radiol. 45, 284-288 (1972) PD 6, 674T, 675T

HALL, E. J.

A comparison of radium and californium 252 using cultured mammalian cells

Radiology 102, 173-179 (1972) NSA 26, 22998

HALL, E. J., L. A. Roizin-Towle and R. D. Colvett

RBE and OER determinations for radium and californium-252

Radio1. 110, 669-704 (1974) NSA 29, 24424

HALL, E. J., and H. H. Rossi

Californium-252 in Teaching and Research, International Atomic

Energy Agency, Vienna, 147 p. (1974) NSA 31, 11530

HALL, R. J. See: 73-SEL

HALL, R. M. See: 69-VER

HAMARD, J.

Maximum permissible concentration of $239 \mathrm{Pu}$ in air (in French)

70-HAZ

71-HAZ

$72-H A Z$

Radioprotection 7, 103-111 (1972) NSA 27, 7801 
HAMILTON, J. G.

44-HAM

Technical progress report on the metabolic studies of fission products

Doc. MDDC-1061 (CH-1572), 2 p. (1944) ADD I, 1061

HAMILTON, J. G.

Metabolism of product for period ending October 15, 1944

Doc. $\mathrm{CN}-2383,22$ p. (1944) NSA 30, 21425

HAMILTON, J. G.

Technical progress report on the metabolic studies of product In: Doc. CN-2786, 29-31 (1945) EP 5, 74

HAMILTON, J. G.

Technical progress report on the metabolic studies of product

In: Doc. CN-2905, 21-23 (1945)

HAMILTON, J. G.

The metabolism of the fission products and the heaviest elements

Radiology 49, 325-343 (1947) BA 22, 10789

HAMILTON, J. G.

The metabolic properties of the fission products and actinide elements

Rev. Mod. Phys. 20, 718-728 (1948) BA 23, 14382

HAMILTON, J. G.

The metabolism of the radioactive elements created by nuclear

fission

New Eng1. J. Med. 240, 863-870 (1949) NSA 3, 216

HAMILTON, J. G.

Metabolic properties of plutonium and allied materials. Tracer

studies. Neptunium-237

In: DoC. UCRL-414, 6-9 (1949)

HAMILTON, J. G., and P. Wallace

Medical and health physics quarterly report: Aerosol studies

Doc. UCRL-2345 Supp., 6 p. (1953) NSA 10, 6097

HAMILTON, J. G., and K. G. Scott

Effect of calcium salt of versene upon metabolism of plutonium

in the rat

Proc. Soc. Expt1. Biol. Med., 83, 301-305 (1953) BA 28, 3494

HAMILTON, J. G. See also: 52-ASL-2, 47-COP, 46-CRJ, 51-FOR, 50-KAW, 46-LAH, 46-SCK-2, 48-SCK, 48-SCK-2, 49-SCK, 49-SCK-2

HAMMARSTROEM, L., and A. Nilsson

Radiopathology of ${ }^{241} \mathrm{Am}$. I. Distribution of americium in adult mice

Acta Radiol., Ther., Phys., Biol. 9, 433-442 (1970) NSA 25, 18901

HAMMARSTROEM, L., and A. Nilsson

Radiopathology of ${ }^{241} \mathrm{Am}$. II. Uptake in the developing teeth of rats

Acta Radiol., Ther., Phys., Bio1. 9, 609-617 (1970) NSA 25, 44759

HAMMER, W. M. See: 62-TAD

HAMMOND, S. E., and E. A. Putzier

Observed effects of plutonium in wounds over a long period of time

49-HAM-2

45-HAM

45-HAM-2

47-HAM

48-HAM

49-HAM

53-HAM

53-HAM-2

70-HAL

70-HAL -2

Health Phys. 10, 399-406 (1964) NSA 18, 29211 
HAMMOND, S. E., C. R. Lagerquist and J. R. Mann

Americium and plutonium urine excretion following acute inhalation

68-HAS exposures to high-fired oxides

Am. Ind. Hyg. Assoc. J. 29, 169-172 (1968) NSA 22, 28351

HAMMOND, S. E.

Industrial-type operations as a source of environmental plutonium

71-HAS

In: Proceedings of Environmental Plutorium Symposium (E. B.

Fowler, et al., eds., Doc. LA-4756) 25-35 (1971) PD 6,2205

HAMMOND, S. E. See also: 70-J0L-2, 72-J0L-2, 65-LAG, 69-LAG, 71$L A G, 72-L A G, 72-L A G-2,73-L A G, 65-P U T$

HANCOCK, N. V. See: 64-PEN

HANSEN, H. See: 70-GJ0

HANSER, H. See: 68-ALK

HANSON, W. C.

Plutonium in lichen communities of the Thule, Greenland region during the summer of 1968

Health Phys. 22, 39-42 (1972) NSA 26, 15547

HANSON, W. C.

Behavior of plutonium in the environment

In: Plutonium Information Meeting for an Ad Hoc Subcommittee

of the Advisory Committee on Reactor Safeguards, Doc. CONF-740115, 64-71 (1974) NSA 31, 14018

HANSON, W. C.

Ecological considerations of the behavior of plutonium in the environment

Health Phys. 28, 529-537 (1975) NSA 32, 11547

HAQUE, A. K. M. M. See: 68-BEV

HARDY, E. P., and P. W. Krey

Determining the accumulated deposit of radionuclides by soil sampling

In: Proceedings of Environmental Plutonium Symposium (E. B.

Fowler, et a1., eds., Doc. LA-4756) 37-42 (1971) PD $\underline{6}, 2206$

HARDY, E. P., Jr., P. W. Krey and H. L. Volchok

Global inventory and distribution of $238 \mathrm{Pu}$ from Snap-9A

Doc. HASL-250, 32 p. (1972) PD $\underline{6}, 3283$

HARDY, E. P., P. W. Krey and H. L. Volchok

Plutonium fallout in Utah

In: Doc. HASL-25\%, I.95-I.118 (1972) NSA 26, 45526

HARDY, E. P., P. W. Krey and H. L. Volchok

Global inventory and distribution of fallout plutonium

Nature 241, 444-445 (1973) NSA 27, 27584

HARDY, E. P.

Worldwide distribution of plutonium (part of AEC presentation

at EPA Plutonium Standards Hearings, December 10-11, 1974)

In: Doc. WASH-1359, 115-128 (1974) NSA 31, 16527

HARDY, E. P. See a 1so: 70-KRP 
HARLEY, J. H.

Worldwide plutonium fallout from weapons tests

71-HAE

In: Proceedings of Environmental Plutonium Symposium (E. B.

Fowler, et al., eds., Doc. LA-4756) 13-19 (1971) PD 6, 2203

HARLEY, J. H. See also: 75-HAI

HARLEY, N. H., B. S. Pasternack and J. H. Harley

Alpha absorption measurements applied to lung dose from

75-HAI

plutonium-239

Health Phys. 28, 61-67 (1975) NSA 31, 23025

HARPER, R. M.

Dismantling an alpha-contaminated facility

74-HAP

Health Phys. 27, 429-432 (1974)

HARRIS, P. S. See: 50-LAN, 66-LAN

HARRIS, S. J. See: 75-ALM

HARVEY, J. R.

Al pha radiation, an external radiation hazard

71-HAV

Health Phys. 21, 866-868 (1971) NSA 26, 9550

HAYES, R.L., J. J. Rafter, L. C. Washburn and B. I. Byrd

Affinity of 253 Es for tumor tissue

Nature New Biol. 246, No. 149, 23-25 (1973) NSA 29, 8101

HAYNES, C. E.

Transuranium element health physics and safety at Oak Ridge

National Laboratory

In: Radiation Protection Problems Relating to Transuranium

Elements (Doc. EUR-4612) 291-325 (1971) NSA 25, 37817

HEALY, J. W.

Estimation of plutonium lung burden by urine analysis

57-HEA

Amer. Ind. Hyg. Assoc. Quart., 18, 261-266 (1957) NSA 11,

12659 EP S3, 346

HEALY, J. W.

Approach to plutonium surface contamination levels

In: Proceedings of the Rocky Flats Symposium on Safety in

Plutonium Handling Facilities (Doc. CONF-710401) 352-364 (1971)

NSA 25, 55195

HEALY, J. W.

Some thoughts on plutonium in soils

71-HEA-2

In: Proceedings of Environmental Plutonium Symposium (E. B. Fowler,

et a1., eds., Doc. LA-4756) 113-115 (1971) PD 6, 2213

HEALY, J. W.

A proposed interim standard for plutonium in soil

Doc. LA-5483-MS, 100 p. (1974) NSA 29, 29342

HEALY, J. W., C. R. Richmond and E. C. Anderson A review of the Natural Resources Defense Council Petition concerning limits for insoluble alpha emitters

Doc. LA-5810-MS, 20 p. (1974) NSA 31, 8954

HEALY, J. W. See also: 73-LAN, 58-NOR, 58-SCL 
HEID, K. R., R. C. Henle and J. M. Selby

Prompt mitigatory action after accidental exposure to radionuclides

68-HE I

In: Diagnos is and Treatment of Deposited Radionuclides ( $H$. A.

Kornberg and W. D. Norwood, eds., Excerpta Medica Foundation,

Amsterdam) 593-599 (1968) NSA 21, 36564; 23, 24658

HEID, K. R., and J. J. Jech

Assessing the probable severity of plutonium inhalation cases

69-HEI

Health Phys. 17, 433-447 (1969) NSA 23, 45773

HEID, K. R., J. J. Jech and B. V. Andersen Interpretation of data on internal plutonium contamination

In: Radiation Protection Problems Relating to Transuranium Elements

(Doc. EUR-4612) 437-468 (1971) NSA 25, 37800

HEID, K. R., and J. J. Jech

Prompt handling of cases involving accidential exposure to plutonium

In: Health Physics Operational Monitoring, Vol. 3 (C. A. Willis,

ed., Gordon and Breach, New York) 1621-1639 (1972) NSA 29, 29862

HEID, K. R. See also: 69-JEC, 72-JEC, 68-LAR, 72-NEL-2, 68-NEW

HELD, E. E.

Radiological resurvey of animals, soils and ground water at Bikini Atoll, 1969-1970

Doc. NVO-269-8 (Rev. 1), 44 p. (1971) NSA 26, 41291 EP S1, 313

HELLER, M.

Bone

In: Histopathology of Irradiation from External and Internal

Sources (W. Bloom, ed., McGraw Hill, New York) 70-161 (1948)

HELLER, M.

The testis

In: Histopathology of Irradiation from External and Internal

Sources (W. Bloom, ed., McGraw Hill, New York) 550-597 (1948)

HEMPELMANN, L. H., S. T. Cantril, J. E. Wirth, J. J. Nickson and S. G. English

Summary of requests for information desired concerning plutonium In: Report of Conference on Plutonium (J. J. Nickson, ed., Doc. $\mathrm{CN}-3167) \quad 1-4(1945) \quad$ EP S3, 287

HEMPELMANN, L. H., and W. H. Langham Determination of systemically deposited plutonium in laboratory personnel and a simple quantitative test for exposure to airborne radioactive material

Doc. AECU-2633, 14 p. (1953) NSA 7, 6348

HEMPELMANN, L. H., C. R. Richmond and G. L. Voelz

A twenty-seven year study of selected Los Alamos plutonium workers Doc. LA-5148, 34 p. (1973) NSA 27, 17696

HEMPELMANN, L. H., W. H. Langham, C. R. Richmond and G. L. Voelz Manhattan Project plutonium workers: A twenty-seven year followup study of selected cases

Health Phys. 25, 461-479 (1973) NSA 28, 30329

HEMPELMANN, L. H., W. H. Langham, G. L. Voelz and C. R. Richmond Biomedical followup on the Manhattan Project plutonium workers

In: Proc. Third Int. Cong. Int. Radiat. Prot. Assn. (W. S.

Snyder, ed., Doc. CONF-730901-P1) Vol. 1, 713-718 (1974) NSA 30, 27212 
HEMPELMANN, L. H. See also: 62-LAN

HENDERSON, R. W. See: $71-$ FOW

MENLE, R. C., and P. E. Bramson

72-HEN

Evaluation of internally deposited ${ }^{241} \mathrm{Am}$ from bioassay data

In: Health Physics Operational Monitoring, Vol. I (C. A. Willis, ed., Gordon and Breach, New York) 731-741 (1972) NSA 29,

29869

HENLE, R. C. See also: 68-HEI, 64-SWA

HERRING, G. M., J. Vaughan and M. Williamson

Preliminary report on the site of localization and possible binding agent for yttrium, americium and plutonium in cortical bone

Health Phys. 8, 717-724 (1962) NSA $\underline{17}, 10332$

HERRING, J.P. See: 62-BAI-3, 73-CRD

HESP, R., and R. M. Ledgerwood

Study of a case which involved a wound contaminated with plutonium

71-HES and $241 \mathrm{Am}$

In: Radiation Protection Problems Relating to Transuranium Elements

(Doc. EUR-4612) 273-287 (1971) NSA 25, 37781

HESS, B. W. See: 62-MIH

HESS, J. 0 . See: 72-BAL

HETHERINGTON, N. W. SEe: 72-BUS

HILL, C. R.

Identification of a-emitters in normal biological materials

Health Phys. $8,17-25$ (1962) NSA 16, 17433

HINCKLEY, J. S. See: 75-NAB

HINTZE, R. See: 62-LOR

HIRSCH, G. M. See: 50-SCH

HOBBS, C. H. See: 72-THR-2

HODGE, H. C., J. N. Stannard and J. B. Hursh (eds.)

Uranium-P1utonium-Transplutonic Elements. Handbook of Experimental

$73-\mathrm{HOC}$

Pharmacology. Vol. 36. Springer-Verlag, New York, 995 p. (1973)

NSA 30,21421

HODGE, V. F., T. R. Folsom and D. R. Young

Retention of fall-out constituents in upper layers of the Pacific

Ocean as estimated from studies on a tuna population

In: Radioactive Contamination of the Marine Environment (International

Atomic Energy Agency, Vienna) 263-276 (1973) NSA 27, 2539

HODGE, V. F., F. L. Hoffman and T. R. Folsom

Rapid accumulation of plutonium and polonium on giant brown algae

Health Phys. 27, 29-35 (1974) NSA 30, 15458

HODGE, V. F., F. L. Hoffman, R. L. Foreman and T. R. Folsom

$62-H I L$

Simple recovery of plutonium, americium, uranium, and polonium

from large volumes of ocean water

Ana 1. Chem. 46, 1334-1336 (1974)

HODGE, V. F. See also: 74-FOL, 75-FOL, 71-WON-2, 72-WON 
HODGES, D. See: 68-LOE, 71-LOE

HOECKER, F. E. See: 53-WIP

HOFFMAN, F. L. See: 74-HOV, 74-HOV-2

HOLLAND, J. Z., and J. E. Miller 69-HOJ Radioactive contamination of the upper atmosphere. Part 1. Atmospheric contamination

In: Progress in Nuclear Energy. Series XII. Health Physics Vol.

II (A. M. F. Duhamel, ed., Pergamon Press, Oxford) 515-534 (1969)

PD 4,1693

HOLLAND, L. M. See: 74-ANE

HOLLAND, W. D. (ed.)

Final report of studies of $238 \mathrm{Pu}$ debris particles from the

$68-\mathrm{HOD}$ SNAP-9A satellite failure of 1964

Doc. TLW-3803-7, 44 p. (1968) NSA 22, 35943

HOLLEY, W. L. See: 72-PAM

HOLLIDAY, B., G. W. Dolphin and H. J. Dunster Radiological protection of workers exposed to airborne plutonium particulate

Health Phys. 18, 529-540 (1970) NSA 24, 44519

HOLLIDAY, B.

Radiological protection of workers handling transuranium elements

In: Radiation Protection Problems Relating to Transuranium

Elements (Doc. EUR-4612) 483-514 (1971) NSA 25, 37821

HOLLINS, J. G., and A. B. Durakovic Metabolism of americium in lactating rats

Health Phys. 22, 627-631 (1972) NSA 26, 38774

HOLLINS, J. G., A. Durakovic and M. C. Storr Retention of americium and calcium by the skeleton of growing and mature female rats

Calcified Tissue Res. 12, 239-246 (1973) NSA 29, 10489

HOLLINS, J. G., M. C. Storr and A. Durakovic Effect of natural physiological stresses and artificial hormonal stresses on the retention of americium and plutonium by rat bone

In: Proc. Third Int. Cong. Int. Radiat. Prot. Assn. (W. S.

Snyder, ed., Doc. CoNF-730901-P1) Vol. 1, 743-748 (1974)

NSA 30,27265

HOLLINS, J. G.

Analysis of the retention of plutonium by the tissues of the rat Radiat. Res. 61, 468-477 (1975) NSA 31, 29978

HOLLINS, J. G. See also: 73-DUA

HOLM, E., and R. B. R. Persson

Fall-out plutonium in Swedish reindeer lichens

Health Phys. 29, 43-51 (1975) NSA 32, 27945

HOLMAN, K. L. See: 67-LAG

HOLT, F. B. See: 67-BRT

HONGO, S. See: 71-SUZ-2 
HORM, I. See: 73-SLO

HORM, J. See: 72-BRO, 71-FAS

HORN, F. L., and A. W. Castleman, Jr.

Plutonium dioxide-uranium dioxide-sodium aerosols produced by

$68-\mathrm{HOR}$

vaporization of fast reactor core materials

In: Treatment of Airborne Radioactive Wastes (International

Atomic Energy Agency, Vienna) 93-115 (1968) NSA 22, 53262

EP S1, 554

HOROVITZ, M. W. See: 72-DUR

HORSTMAN, V. G. See: 62-BUS, 62-CAB, 58-CLA

HOWARD, A. See: 73-NIA

HOWARD, E. B.

7!-HOW

The morphology of experimental lung tumors in beagle dogs

In: Morphology of Experimental Respiratory Carcinogenes is ( $P$.

Nettesheim, et a1., eds., Doc. CONF-700501) 147-160 (1971)

NSA 25, 32527

HOWARD, E. B. See also: 69-PAR, 71-PAR

HOWDEN, S. See: 75-STH, 75-STH-2

HOWELLS, H., G. B. Schofield, J. C. Lynn and F. A. Ward Assessment and management of a plutonium contaminated wound case

In: Health Physics Problems of Internal Contamination (E. Bujdoso,

ed., Akademiai Kiado, Budapest) 601-603 (1973) NSA 28, 30322

HOWELLS, H. See also: 74-SCG

HROMYK, E. See: 69-TAG-3

HSIEH, J. J. C., F. P. Hungate and S. A. Wilson

Autoradiography: Technique for drastic reduction in exposure time to alpha particles

Science 150, 1821-1822 (1965) NSA 20, 12563

HSU, T. H. S. See: 73-FAB

HUFFMAN, F. N. See: 69-NOM, 73-NOM, 69-SAG, 70-SAG

HUMASON, G. See: 67-LUS

HUNGATE, F. P., J. E. Ballou, D. D. Mahlum, M. Kashima, V. H. Smith,

C. L. Sanders, D. W. Baxter, M. R. Sikov and R. C. Thompson

72-HUF

Preliminary data on $25{ }^{3} \mathrm{Es}$ and ${ }^{249} \mathrm{BK}$ metabolism in rats

Health Phys. 22, 653-656 (1972) NSA 26, 38777

HUNGATE, F. P. See also: 58-BA1, 65-HSI

HUNT, D. C.

Restricted release of plutonium. Part 1. Observationa? Data

73-HOE

$65-H S I$

Nuc1. Safety 12, 85-89 (1971) NSA 25, 26781

HUNT, D. C.

Restricted release of plutonium. Part 2. Theory

$71-$ HUN

Nuc1. Safety 12, 203-216 (1971) NSA 25, 26782

HUNZINGER, W. See: 71-ALD, 71-DRE

HURSEN, T. F. See: 73-PAV 
HURSH, J. B. See: 73-HOC

HUTH, G. C., and P. J. Moldofsky

$71-$ HUT

In vivo measurement of plutonium and other very low energy emitters

In: Advances in Physical and Biological Radiation Detectors

(International Atomic Energy Agency, Vienna) 225-234 (1971)

NSA 25,57770

HYATT, E. C. See: 6T-MOW

HYLTON, D. B. See: 69-LAG, 71-LAG, 72-LAG, 72-LAG-2, 73-LAG, $73-N O R$ 
IDE, H. M. See: 72-JOL

ILYIN, L. A.

$74-I L Y$

Regularities in metabolism of radioactive isotopes upon incidence on the skin

In: Proc. Int. Cong. Int. Radiat. Prot. Assn. (W. S. Snyder, ed.,

Doc. CONF-730901-P2) Vol. 2., 1371-1376 (1974) NSA 30, 27270

IMAI, T. See: 71-SAK-2

INOUE, $Y$. , and M. Sakanoue

The determination of plutonium in soil samples

J. Radiat. Res. 11, 98-106 (1970) NSA 25, 47

INTERNATIONAL Atomic Energy Agency

Safe Handling of Plutonium: A Panel Report (International

Atomic Energy Agency, Vienna) 132 p. (1974) NSA 29, 24865

INTERNATIONAL Commission on Radiological Protection - Task Group

on Lung Dynamics

Deposition and retention models for internal dosimetry of the

human respiratory tract

Health Phys. 12, 173-207 (1966)

INTERNATIONAL Commission on Radiological Protection

Review of the Radiosensitivity of the Tissues in Bone. ICRP

Publication 11, Pergamon Press, New York, 36 p. (1968) NSA 25, 42472

INTERNATIONAL Commission on Radiological Protection

Report of Committee IV on Evaluation of Radiation Doses to Body

Tissues from Internal Contamination due to 0ccupational Exposure. ICRP Publication 10, Pergamon Press, New York, 64 p. (1968)

NSA 25, 42467

INTERNATIONAL Commission on Radiological Protection (Comm. 4)

70-INO

74-INA

Assessment of Internal Contamination Resulting from Recurrent or Prolonged Uptakes. ICRP Publication 10A, Pergamon Press, New York, 34 p. (1971) NSA 25, 57919

INTERNATIONAL Commission on Radiological Protection (Task Group

of Committee 2)

The Metabolism of Compounds of Plutonium and other Actinides.

ICRP Publication 19, Pergamon Press, New York, 59 p. (1972)

NSA $2 \underline{7}, 12379$

IOVLEV, I. V. See: 72-KOS-2

IRANZO, E.

First results from the programme of action following the Palomares

68-IRA accident

In: Radiological Protection of the Public in a Nuclear Mass

Disaster, Proceedings of a Symposium, Interlaken, Switzerland,

1968 (H. Brunner and S. Pretre, eds., Fachverband fuer

Strahlenschutz) 446-455 (1968) NSA 23, 20200 EP 6, 222

IRANZO, E., and E. Ramos

$68-$ INT -2

68- INT

$71-$ INT

Measures to determine the risk to which a population can be subjected as a result of a nuclear accident generating radioactive aerosols

In: Environmental Contamination by Radioactive Material

(International Atomic Energy Agency, Vienna) 529-540 (1969)

translated in LA-tr-74-10 NSA 24, 7879

72-INT

IRANZ0, E. See also: 68-FOW 
ISAAC, E. L. See: 62-PAH

IZAWA, M. See: 72-TAK 
JAAKKOLA, T. See: 74-MUH, 74-TUL

JACKSON, S., and G. W. Dolphin

Estimation of internal radiation dose from metabolic and urinary

$66-\mathrm{JAC}$ excretion data for a number of important radionuclides

Health Phys. 12, 481-500 (1966) NSA 20, 20398

JACKSON, T. A. See: 71-SAN-1, 72-SAN-2

JACOBS, D. G., and T. Tamura

Retention and movement of radioisotopes in soils

59-JAD

Nucl. Safety 1, 65-69 (1959) EP S1, 812

JACOBS, D. G. See also: 60-0LS, 69-THW

JACOBS, H. See: 70-BAI-5

JACOBSON, L., and R. Overstreet

The uptake by plants of plutonium and some products of nuclear fission adsorbed on soil colloids

Soil Sci. 65, 129-134 (1948)

JACOBSON, L. See also: 43-OVE

JACOBSON, L. O., and E. L. Simmons

Part 6 . The hematological effect of parenterally administered piutonium in mammals

In: The Toxicity and Metabolism of Plutonium in Laboratory

Animals (R. D. Finkle, et al., eds., Doc. MDDC-1140) (1946)

EP $\underline{S 2}, 9$

JACOBSON, L. O., E. K. Marks and E. Lorenz

The hematological effects of ionizing radiation

Radiology 52, 371-395 (1949) Also in: Industrial Medicine on the

Plutonium Project (R. S. Stone, ed., McGraw-Hil1, New York)

$140-196$ (1951) BA 23, 18041

JACOBSON, L. 0 . See also: 46-ABR, 46-FID

JAENKE, R. See: 75-DAG

JAMES, A. C., and G. Rowden

An electron microscope autoradiographic study of plutonium

localization in rat liver using a $241 \mathrm{Pu}$ label

Int. J. Appl. Radiat. Isotop. $\underline{20}, 295-297$ (1969) NSA 23, 45642

JAMES, A. C., and N. F. Kember

Alpha particle incidence in small targets

Phys. Med. Biol. 15, 39-46 (1970) NSA 24, 33953

JAMES, A. C., and D. M. Taylor

DTPA therapy for chelation of ${ }^{239} \mathrm{Pu}$ in bone: The influence of bone remodelling

Health Phys. 21, 31-39 (1971) NSA 25, 46697

JAMES, A. C., and N. F. Kember

Dose measurements from skeletal plutonium compared in mammalian species

In: Radiobiology of Plutonium (B. J. Stover and W. S. S. Jee, eds.,

J. W. Press, Salt Lake City) 281-291 (1972) NSA 26, 41300

JAMES. A. C.

Dose to osteogenic cells from ${ }^{239} \mathrm{Pu}$ deposited in rat bone

48-JAL

$46-\mathrm{J} A O$

Radiat. Res. 51, 654-673 (1972) NSA 26, 59128 
JAMES. A. C. See a7so: 69-ROW, 71-TAY-2

JAMMET, H. See: 72-GON, 64-PIJ

JAMPSIN, B. See: 71-BER

JAWOROWSKI, Z., J. Bilkiewicz and E. Zylicz

Incorporation of $239 \mathrm{Pu}$ into the hair

Int. J. Radiat. Biol. 20, 79-83 (1971) NSA 25, 55116

JAWOROWSKI, Z., J. Bilkiewicz and I, Radwan

Influence of irradiation on the incorporation of radionuclides

In: Health Physics Problems of Internal Contamination (E. Bujdoso, ed., Akademiai Kiado, Budapest) 303-306 (1973) NSA 28, 30185

JAWOROWSKI, Z., J. Bilkiewicz and E. Zylicz

$239 \mathrm{Pu}$ incorporation in hair (in Polish)

Postepy Fiz. Med. 8,.173-178 (1973) NSA 31, 23086

JEANMAIRE, L., F. Patti and M. L. Audren

Interpretation of data relating to plutonium contamination

In: Assessment of Radioactivity in Man, Vol. 2 (International

Atomic Energy Agency, Vienna) 617-628 (1964) translated in

CONF-448-36, 17 p. NSA 23,29465

JEANMAIRE, L., and J. Ballada

Study of two cases of $241 \mathrm{Am}$ contamination (in French)

$71-J A W$

In: Radiation Protection Problems Relating to Transuranium Elements

(Doc. EUR-4612) 531-546 (1971) NSA 25, 37802

JEANMAIRE, L. See also: 67-BOU

JECH, J. J., K. R. Heid and H. V. Larson

Prompt assessment and mitigatory action after accidental intake of plutonium

In: Handling of Radiation Accidents (International Atomic Energy

Agency, Vienna) 77-93 (1969) NSA 24, 7863

JECH, J. J., B. V. Andersen and K. R. Heid

Interpretation of human urinary excretion of plutonium for cases treated with DTPA

Health Phys. 22, 787-792 (1972) NSA 26, 38753

JECH, J. J. See a 7so: 72-BRP, 69-HEI, 71-HEI, 72-HEI

JEE, W. S. S., and J. S. Arnold

Radioisotopes in the teeth of dogs-I The distribution of plutonium, radium, radiothorium, mesothorium and strontium and the sequence of histopathologic changes in teeth containing plutonium

Arch. Oral Biol. 2, 215-238 (1960) EP ㅁ, 85

JEE, W. S. S., and J. S. Arnold Effect of internally deposited radioisotopes upon blood vessels of cortical bone

Proc. Soc. Expt]. Biol. Med. 105, 351-356 (1960) NSA 15, 3899

JEE, W. S. S., and J. S. Arnold

The toxicity of plutonium deposited in skeletal tissues of beagles. I. The relation of the distribution of plutonium to the sequence of histopathologic bone changes

Lab. Invest. 10, 797-825 (1961) NSA 17, 10346

73-JAW-2

64-JEA

71-JEA

69-JEC

72-JEC

60-JEW

60-JEW-2

61-JEW 
JOFFE, M. H., and L. A. Temple

The effect of zirconium citrate on the distribution of

intravenously administered plutonium in the dog. I. Preliminary observations

In: Doc. HW-28636, 92-97 (1953) EP S2, 148

JOHANSON, E. W. See: 66-EPS

JOHNSON, H. A. See: 62-TAG-2

JOHNSON, J. E. See: 71-PAI, 70-WAR

JOHNSON, G. L. See: 75-ADM

JOHNSON, L. J.

Relative translocation and distribution of $\mathrm{Pu}$ and $\mathrm{Am}$ from

$69-J O L$ experimental $\mathrm{PuO}_{2}$ subcutaneous implants in beagles (Thesis, Colorado State Univ..)

Doc. C00-1787-6, 212 p. (1969) NSA 24, 11904

JOHNSON, L. J., E. H. Bu11, J. L. Lebel and R. L. Watters Kinetics of lymph node activity accumulation from subcutaneous $\mathrm{PuO}_{2}$ implants

Health Phys. $18,416-418$ (1970) NSA 24, 25383

JOHNSON, L. J., R. L. Watters, C. R. Lagerquist and S. E. Hammond Relative distribution of plutonium and americium following experimental $\mathrm{PuO}_{2}$ implants

Heaith Phys. 19,743-749 (1970) NSA 25, 16012

JOHNSON, L. J., P. N. Dean and H. M. Ide

In vivo determination of the late-phase lung clearance of $239 \mathrm{Pu}$ following accidental exposure

Health Phys. 22, 410-412(1972) NSA 26, 28511

JOHNSON, L. J., R. L. Watters, J. L. Lebel, C. R. Lagerquist and

S. E. Hammond

Distribution of $\mathrm{Pu}$ and $\mathrm{Am}$ : Subcutaneous administration of $\mathrm{PuO}_{2}$ and the effect of chelation therapy

In: Radiobiology of Plutonium (B. J. Stover and W. S. S. Jee, eds.,

J. W. Press, Salt Lake City) 213-220 (1972) NSA 26, 41296

JOHNSON, L. J., and J. N. P. Lawrence

Plutonium contaminated wound experience and assay techniques at the Los Alamos Scientific Laboratory

Health Phys. 27, 55-59 (1974)

JOHNSON, L. J. See aTSO: 72-ETI, 74-HAK-1, 74-HAK-2, 70-LEJ, 71-PER, 72-WAR-2

JOHNSON, 0. See: 55-FOR

JOHNSON, W. S., Sr.

Plutonium contamination of large land areas

In: Proceedings of the lst International Congress of Radiation

Protection. Part 1. (W. S. Snyder, et al., eds., Pergamon Press, New York) 379-383 (1968) NSA 23, 12124

JOLLY, L., Jr., H. A. McClearen, G. A. Poda and W. P. Walke Treatment and evaluation of a $239 \mathrm{Pu}$ nitrate contaminated puncture wound. A two-year case history

Health Phys. 23, 333-341 (1972) NSA 26, 50975 
JEE, W. S. S., B. J. Stover, G. N. Taylor and W. R. Christensen

62-JEW

The skeletal toxicity of $\mathrm{Pu}^{239}$ in adult beagles

Health Phys. 8 , 599-607 (1962) NSA 17, 10320

JEE, W. S. S. : and J. S. Arnold

The failure of plutonium to deposit in the osteoid of rachitic rats

Hea1th Phys. $8,709-711$ (1962) NSA 17,10330

JEE, W. S. S., J. S. Arnold, T. H. Cochran, J. A. Twente and R. S. Mica 1

Relationship of microdistribution of alpha particles to damage

In: Some Aspects of Internal Irradiation ( $T$. F. Dougherty, et al., eds., Pergamon Press, Oxford) 27-45 (1962) NSA 17, 19885

JEE, W. S. S.

Histopathological endpoints in compact bones receiving alpha radiation

In: Some Aspects of Internal Irradiation (T. F. Dougherty, et al., eds., Pergamon Press, Oxford) 95-116 (1962) NSA 17, 19889

JEE, W. S. S.

A critical survey of the analysis of microscopic distribution of some bone-seeking radionuclides and assessment of absorbed dose

In: Assessment of Radioactivity in Man, Vol. 1 (International

Atomic Energy Agency, Vienna) 369-393 (1964) NSA 19, 29880

JEE, W. S. S., M. H. Bartley, N. L. Dockum, J. Yee and G. H. Kenner

Vascular changes in bone following bone-seeking radionuclides

In: Delayed Effects of Bone-Seeking Radionuclides (C. W. Mays,

et al., eds., Univ. Utah Press, Salt Lake City) 437-455 (1969)

NSA 23, 38797

JEE, W. S. S.

Bone-seeking radionuclides and bone

In: Pathology of Irradiation (C. C. Berdjis, ed., Williams and

Wilkins, Co., Baltimore) 186-212 (1971) NSA 25, 29630

JEE, W. S. S.

Distribution and toxicity of ${ }^{239} \mathrm{Pu}$ in bone

Health Phys. $\underline{22}, 583-595$ (1972) NSA 26, 38769

JEE, W. S. S., and R. B. Dell High resolution neutron-induced autoradiography of bone containing

Health Phys. $22,761-763$ (1972) NSA 26, 38789

JEE, W. S. S.

$2{ }^{39} \mathrm{Pu}$ in bones as visualized by photographic and neutron-induced autoradiography

In: Radiobiology of Plutonium (B. J. Stover and W. S. S. Jee, eds.,

J. W. Press, Salt Lake City) 171-193 (1972) NSA 26, 41295

JEE. W. S. S. See also: 57-ARN, 59-ARN, 62-ARN, 72-CHR, 62-COH, 62-D0T, 75-FEL, 72-LOR-2, 69-MAY, 70-MAY, 72-PAZ, 63-STB, 72-STB, 62-TAG, 66-TAG, 69-TAG-2, 69-TAG-3, 72-TAG, 72-TAG-2, 72-TAG-3, 62-TAD, 61-TWE

62-JEW-2

62-JEW-3

62-JEW-4

64-JEW

69-JEW

71-JEW

72-JEW

72-JEW-2

72-JEW-3

JETT, J. H. See: 74-RAJ

JEUNG, N. See: 61-DUR, 69-DUR

JOCKEY, P. See: 70-KUN-2 
JONES, E. W., and W. N. Saxby

Detection and measurement of plutonium contamination in wounds

$68-J O N$ In: Proceedings of the First International Congress of Radiation Protection, Part 2 (W. S. Snyder, et al., eds., Pergamon Press, New York) 1295-1307 (1968) NSA 23, 14188

JONES, I. S., and S. F. Pond

Some experiments to determine the resuspension factor of plutonium

67-JOI from various surfaces

In: Surface Contamination (B. R. Fish, ed., Pergamon, 0xford) 83-92 (1967) NSA 19, 20191

JONES, J. D. SEe: 72-TAY-3

JONES, R. K. See: 72-THR-2

JONES, T.D. See: 75-DIT

JORDAN, H. S.

Distribution of plutonium from accidents and field experiments

In: Proceedings of Environmental Plutonium Symposium (E. B. Fowler, et a 1. , eds., Doc. LA-4756) 21-24 (1971) PD 6, 2204

JORDAN, H. S.

Release of plutonium to the atmosphere

In: Plutonium Information Meeting for an Ad Hoc Subcommittee of the Advisory Committee on Reactor Safeguards, Doc. CONF-740115, 16-29 (1974) NSA 37, 14017

JOSHI, P. V. See: 71-KEL

JOSHIMA, H., M. Kashima, Y. Noda and 0. Matsuoka

Effect of Ca-DTPA on the whole body retention and tissue

distribution of monomeric and polymeric plutonium in mice

In: Final Report of Research Project on Plutonium Hazards, April

1966 - March 1970 (M. Suzuki et al., eds., Doc. NIRS-PU-8) 39-44

(1971) PD 6, 1575 EP S1, 525

JOSHIMA, H. See also: 71-KAS, 75-KAS, 71-MA0, 71-MAO-2, 71-MA0-3, 72-MAO

JOVEN, C. B. See: 69-WAC 
KAIDANOVSKII, G. N. See: 73-DOE, 74-D0E, 74-DOE-2

KALISTRATOVA, V. S., G. S. Oksentyuk and V. F. Kryuk

$71-K A V$ Change in metabolism at remote times after exposure to radioactive americium

In: Remote Aftereffects of Radiation Damage (Y. I. Moskalev, ed.,

Atomizdat, Moscow) 401-406 (1971) translated in AEC-tr-7387,

441-446 EP S3, 338

KAL ISTRATOVA, V. S., I. S. Katsapov and V. I. Trifonov Biological effects observed with combined exposure to radiations (in Russian)

In: Proc. Third Int. Cong. Int. Radiat. Prot. Assn. (W. S. Snyder, ed., Doc. CONF-730901-P1) Vol. 1, 172-177 (1974) NSA 30, 27155

KALISTRATOVA, V. S. See also: 72-MOS-3

KALMYKOVA, Z. I.

Oxygen saturation of blood of rats after inhalation of plutonium-239 In: Distribution, Biological Effects, and Rapid Excretion of Radioactive Isotopes (Y. I. Moskalev, ed., Meditsina, Moscow) 230-236 (1964) translated in AEC-tr-7590, 243-250 NSA 19, 40380

KALMYKOVA, Z. I.

State of the red blood cells and hemodynamics in the case of inhalation of ammonium plutonium pentacarbonate by rats Radiobiologiya $8,925-927$ (1968) translated in AEC-tr-7013, 204-208 NSA 23, 17947

KALMYKOVA, Z. I.

On certain changes in the red blood and hemodynamics under the inhalation injury of rats by a citrate of $239 \mathrm{Pu}$

In: Radioactive Isotopes and the Body (Y. I. Moskalev, ed.,

Meditsina, Moscow) (1969) translated in AEC-tr-7195, 354-363

NSA 25,24325

KALMYKOVA, Z. I.

Respiratory insufficiency and compensation thereof in the presence of injury to rats from plutonium 239 inhalation

In: Biological Effects of Radiation from External and Internal Sources

(Y. I. Moskalev and V. S. Kalistratova, eds., Meditsina, Moscow) 270-

276 (1972) translated in AEC-tr-7457, 398-406 NSA 30, 9969

KALMYKOVA, 2. I., and V. N. Karpova

Condition of dog erythrocytes after inhalation of different doses of americium 241

In: Biological Effects of Radiation from External and Internal

Sources (Y. I. Moskalev and V. S. Kalistratova, eds., Meditsina, Moscow) 315-320 (1972) translated in AEC-tr-7457, 460-467

NSA $\underline{30}, 9975$ PD $\underline{8}, 659 T$

KALMYKOVA, Z. I., and V. N. Doshchenko Changes in the dog's cardiovascular system for inhalation of americium

In: Biological Effects of Radiation from External and Internal Sources (Y. I. Moskalev and V. S. Kal istratova, eds., Meditsina, Moscow) 320-342 (1972) translated in AEC-tr-7457, 468-474 NSA $\underline{30}, 9973$ PD $\underline{8}, 658$ T

KALMYKOVA, Z. I. See also: 61-BOG, 62-BOG, 69-BUL-2, 70-BUL, 71-BUL-2, 72-BUL, 74-KAO 
KANAPILLY, G. M., O. G. Raabe and H. A. Boyd

Method for determining the dissolution characteristics of

accidentally released radioactive aerosols

In: Proc. Third Int. Cong. Int. Radiat. Prot. Assn. (W. S. Snyder, ed., Doc. CONF-730901-P2) Vo1. 2, 1237-1242 (1974) NSA 30,

27246

KANAPILLY, G. M. See also: 75-RAB

KAPSHUKOV, I. I., G. N. Yokovlev, 0. V. Shiba, G. A. Timofeev

69-KAP and L. V. Sudakov

Radiation stability of ${ }^{244} \mathrm{Cm}$ and ${ }^{238} \mathrm{Pu}$ dioxide under selfirradiation (in Russian)

At. Energ. (USSR) 27, 337-338 (1969) NSA 24, 10200

KARPOVA, V. N., and Z. I. Kalmykova Effect of pentacin and lydase on the rate of ${ }^{241} \mathrm{Am}$ elimination from the body of rats (in Russian)

Gig. Sanit. (6), 47-51 (1974) NSA 30, 24399

KARPOVA, V. N. See also: 72-BUL, 72-KAL-2

KASHIMA, M., H. Joshima and 0. Matsuoka Autoradiographic studies on the distribution pattern of monomeric and polymeric $\mathrm{Pu}$ following three routes of administration

In: Final Report of Research Project on Plutonium Hazards, April

1966 - March 1970 (M. Suzuki, et a1., eds., Doc. NIRS-Pu-8) 29-32

(1971) PD 6, 1572 EP S1, 522

KASHIMA, M., D. D. Mahlum and M. R. Sikov

Metabolism and effect of monomeric and polymeric plutonium in the immature rat liver

Health Phys. 22, 749-752 (1972) NSA 26, 38744

KASHIMA, M.

Application of autoradiography to studies of internal irradiation with special reference to $\mathrm{Pu}$ (in Japanese)

Hoshasen Kagaku 16(6), 111-115 (1973) NSA 29, 10482

KASHIMA, M., H. Joshima and 0. Matsuoka

Distribution of micron sized polymeric ${ }^{239} \mathrm{Pu}$ in mice (Abstract) Health Phys. 29, 230 (1975)

KASHIMA, M. See also: 72-HUF, 71-JOS, 71-MA0, 71-MAO-2, 71-MA0-3, 72-MAO

KATHREN, R. L.

Towards interim acceptable surface contamination levels for environmental $\mathrm{PuO}_{2}$

In: Radiological Protection of the Public in a Nuclear Mass Disaster, Proceedings of a Symposium, Interlaken, Switzerland, 1968 (H. Brunner and S. Pretre, eds., Fachverband fuer Strahlenschutz) 460-470 (1968)

NSA 22, 51562; 23, 20202

KATSAPOV, I. S. SEe: 74-KAV

KATSURAGI, K. See: 68-MIY, 70-MIY

KATZ, J., H. A. Kornberg and H. M. Parker 
KATZ, J., M. H. Weeks and W. D. Oakley

Relative effectiveness of various agents for preventing the internal

$55-$ KAT-2 deposition of plutonium in the rat

Radiat. Res. 2, 166-170 (1955) NSA \&, 6077

KATZ, J. See a lso: 53-WEK-2, 56-WEK

KAUFFMAN, P. E., and P. J. Magno

Plutonium-239 in total diet and milk

Radio1. Health Data Rep. 8, 191-194 (1967) NSA 22, 28513

KAUFFMAN, P. E. See also: 67-MAG, 69-MAG

KAUFMAN, H. R. See: 68-ODL-2

KAWIN, B., D. H. Copp and J. G. Hamilton

Studies of the metabolism of certain fission products and plutonium

50-KAW

Doc. UCRL-812, 120 p. (1950) NSA 5, 318

KAWIN, B., and D. H. Copo

Effect of 2,3-dimercaptopropanol (BAL) upon distribution and excretion of plutonium

Proc. Soc. Expt1. Biol. Med. 84, 576-577 (1953) NSA 18, 1508

KAWIN, B., and N. L. Dockum

Distribution and retention of plutonium in rats

58-KAW

In: Doc. HW-53500, 95-101 (1958) EP S2, 248

KAWIN, B.

Effects of zirconium citrate on early femur uptake and urinary

excretion of radioisotopes

Hea 1th Phys. 9, 1031-1034 (1963) NSA 18, 3460

KAWIN, B. See also: 56-COP, 58-VOG

KAZACHEVSKII, I. V. See: 65-CHE

KE, C. H. See: 73-SLO

KEANE, A. T. See: 72-EVA, 73-ROL, 72-RUN, 73-THU

KEELY, R. B., and T. K. Wenstrand

Impact of fuel reprocessing on the health physics profession

$71-K E R$

Health Phys. 20, 143-151 (1971) NSA 25, 35140

KEILHOLTZ, G. W. See: 72-FIS

KELLAR, D. N., and P. V. Joshi

Size spectrum of plutonium aerosols: Parameter for evaluation of inhalation hazard

In: Proceedings of the National Symposium on Radiation Physics, Bombay, 417-425 (1971) NSA 26, 40839

KELLER, C.

Chemical, nuclear, and biological properties of the transuranium elements (in German)

Naturwiss. Rundsch. 26, 191-204 (1973) NSA 28, 24362

KELLER, N. See: 59-STB-2

KEMBER, N. F. See: 70-JAM, 72-JAM, 61-TAY

KENNEDY, N. C. See: 73-ANS 
KENNEDY, W. R., and W. D. Purtymun

Plutonium and strontium in soil in the Los Alamos, Espanola, and

70-KEN

Santa Fe, New Mexico areas

Doc. LA-4562, 4 p. (1970) NSA 25, 15763

KENNEDY, W. R., and W. D. Purtymun

Plutonium and strontium in soil near Technical Area 12, Los Alamos

71-KEN

Scientific Laboratory, Los Alamos, New Mexico

Doc. LA-4563, 5 p. (1971) NSA 25, 18985

KENNER, G. H. See: 69-JEW

KEYANONDA, P. See: 55-DOJ

KHALTURIN, G. V., and A. K. Zhuravleva

Preparation of standard nitrate solutions of hexavalent and

72-KHA

pentavalent neptunium for biological experiments

In: Biological Effects of Radiation from External and Internal

Sources (Y. I. Moskalev and V. S. Kalistratova, eds.,

Meditsina, Moscow) 197-201 (1972) translated in AEC-tr-7457, 297-302

NSA 30,9214

KHALTURIN, G. V., and Y. P. Sevastyanova

Standard plutonium nitrate and citrate solutions for biological experiments

In: Biological Effects of Radiaton from External and Internal

Sources (Y. I. Moskalev and V. S. Kalistratova, eds., Meditsina,

Moscow) 201-204 (1972) translated in AEC-tr-7457, 303-308 NSA

30,9215

KHALTURIN, G. V., E. P. Sevostyanova, A. K. Zhuravleva, and

74-KHA

L. A. Buldakov

Effect of valency and type of $239 \mathrm{Pu}$ chemical compound on its distribution in the body

Gig. Sanit. 1974 (5), 38-42 (1974) translated in ORNL-tr-4005

NSA 30,$16057 ; 3220018$

KHALTURIN, G. V. See also: 72-BUL-2, 72-BUL-4

KHODYREVA, M. A.

Penetration of $239 \mathrm{Pu}$ through the skin (in Russian)

$65-\mathrm{KHO}$

Med. Radio1. 10, 42-46 (1965) NSA 20, 16183

KHODYREVA, M. A.

Absorption of $239 \mathrm{Pu}$ through the skin of animals and its distribution

$66-\mathrm{KHO}$ in the organism

In: Distribution and Biological Effects of Radioactive Isotopes

(Y. I. Moskalev, ed., Atomizdat, Moscow) 78-83 (1966) translated

in AEC-tr-6944, 99-105 NSA 23, 22162

KHODYREVA, M. A., R. Y. Sitko, G. M. Parkhomenko and V. A.

Sarychev

Decontamination of skin from transuranium elements (in Russian)

Gig. Sanit. 12, 57-61 (1972) NSA 27, 25028

KHODYREVA, M. A., A. V. Simakov, N. A. Andreeva, and R. Y. Sitko

Hygienic assessment of the effectiveness of means of decontaminating skin surfaces contaminated with $237 \mathrm{~Np}$ (in Russian)

Gig. Sanit. 1974 (11), 31-35 (1974) NSA 31, 11662

KHODYREVA, M. A. See also: 68-TAN 
KIEFER, H., and R. Maushart

Determination of plutonium-239 body burden using gamma spectrometry

$62-K I E$ with proportional counters

In: Whole Body Counting (Internationai Atomic Energy Agency, Vienna)

289-293 (1962) NSA 16, 16148

KIEFER, H., and R. Maushart

Demonstration of plutonium incorporation by direct measurement (in German)

Atompraxis 14, 338-344 (1968) NSA 22, 49343

KIEFER, H., and G. Moehrle

Experience acquired from incidents with transuranic elements

(in German)

In: Radiation Protection Problems Related to Transuranium Elements

(Doc. EIJR-4612) 585-593 (1971) NSA 25, 37822

KIEFER, H. See also: 64-EHR

KIMMEL, D. B. See: 75-FEL

KING, L. J., and W. T. MCCarley

Plutonium release incident of November 20, 1959

Doc. ORNL-2989, 77 p. (1961) NSA 15, 9237

KINNEAR, J. E. See: 73-ROM, 75-ROM

KIRCHNER, R. A. See: 67-MAN

KISIELESKI, W. , and L. Woodruff

Studies on the distribution of plutonium in the rat

In: Doc. ANL-4108, 86-103 (1947) EP S3, 284

KISIELESKI, W. See also: 65-DOS, 46-FID, 53-LIS, 46-PAE, 46-SNR, 46-SNR-2, 46-SNR-3

KIY, M. R., and V. M. Schneider

Wound contamination experience; first aid on working premises

(in German)

In: Radiation Protection Problems Relating to Transuranium Elements

(Doc. EUR-4612) 573-583 (1971) NSA 25, 37783

KLEINMAN, M. T., and H. L. Volchok

Radionuclide concentrations in surface air: Direct relationship to global fallout

Science $166,376-377$ (1969) NSA 24, 323

KLEINMAN, M. T. See also: 72-VOH-2

KLEINSCHMIDT, J. See: 47-CAR

KLEINSCHMIDT, R. See: 47-CAR

KLEPPER, E. L. See: 74-CRI

KLICKOV, 0. V. See: 71-0SA, 71-0SA-3

KLOKE, A., and F. Ludwieq

Strontium-90, Cesium-137 and plutonium-239 in hav samples from

68-KIE

71-KIE

$61-K I N$ 1953 to 1961

Naturwissenschaften $49,65-67$ (1962) NSA 16, 20128

KLOPFER, D. C. See: 74-EMR

KLYZHUK, K. N. See: 62-LEM-3 
KNEIP, T. J., and G. J. Lauer

Trace metal concentration factors in aquatic ecosystems

73-KNE

In: Chemical Analysis of the Environment and 0ther Modern Techniques

(S. Ahuja, et al., eds., Plenum Press, New York) 43-62 (1973)

NSA 29,827 PD 8,1834

KNUDSON, D. H. See: 73-FAB

KNUTH, R. H. See: 72-VOH-2

$\mathrm{KOCH}, \mathrm{G}$. See: 71-DUL

$\mathrm{KOCH}, \mathrm{J}$.

A preliminary report on the B-52 accident in Greenland on January 21, 1968

In: Radiological Protection of the Public in a Nuclear Mass

Disaster, Proceedings of a Symposium, Interlaken, Switzerland, 1968 (H. Burnner and S. Pretre, eds., Fachverband fuer

Strahlenschutz) 39-45 (1968) NSA 23, 20182

KOENIG, L. A., and H. Schieferdecker

Assessment of uranium and plutonium body burdens. Methods and techniques

At. Energy Rev. 12, 343-417 (1974) NSA 30, 21412

KOLOTVIN, V. A. See: 74-NEM

KONSTANTINOV, J. E. See: 70-LEI

KONSTANTINOVA, V. V., and R. Y. Libinzon

Nucleic acid content and synthesis in liver during subacute

poisoning by plutonium (in Russian)

voprosy Med. Khim. 4, 339-344 (1958) NSA 13, 20861

KONSTANTINOVA, V. V., and R. E. Libinzon

The effect of plutonium on the content and renewal of nucleic

acids in some rabbit tissues

Biochemistry (U.S.S.R.), 24, 974-981 (1959) translated by

Consultants Bureau, $897-90 \overline{3}$ NSA 14, 17717

KONSTANTINOVA, V. V.

Urea synthesis and arginase activity in plutonium-injured rats

In: Plutonium-239: Its Distribution, Biological Effect and Accelerated

El imination (A. V. Lebedinskii and Y. I. Moskalev, eds., Medgiz, Moscow)

63-65 (1962) translated in FTD-TT-63-559, 88-91 NSA 17, 30277

KONSTANTINOVA, $V . V$.

Content and regeneration of nucleic acids in rat liver following plutonium injury

In: Plutonium-239: Its Distribution, Biological Effect and Accelerated

Elimination (A. V. Lebedinskii and Y. I. Moskalev, eds., Medgiz, Moscow)

$66-73$ (1962) translated in FTD-TT-63-559, 92-103 NSA 17, 30278

KONSTANTINOVA, V. V.

Physico-chemical changes in desoxyribonucleic acid brought about by $\mathrm{Pu}^{239}$ in vivo

Radiobiologiya 3, 336-340 (1963) translated in AEC-tr-5436, 11-17

NSA 17,31923

KONSTANTINOVA, V. V.

Deoxyribonuclease activity in rabbit liver affected by plutonium Radiobiologiya 3, 501-503 (1963) translated in AEC-tr-5437, 19-22 NSA 18,6662 
KONSTANTINOVA, V. V. See also: 62-BEL, 62-BEL-2, 62-LIB, 62-LIB-2

KORELINA, N. F. See: 74-LIK

KORNBERG, H. A. See: 55-KAT, 68-MCB, 62-MCR-2, 56-TH0-2, 56-WEK

KOSAKA, T. SEe: 72-TAK

KOSHURNIKOVA, N.A.

The histopathology of the sex glands of rabbits under the action

$61-K O S$ of incorporated plutonium

In: Biological Effects of Radiation and Problems of Radioactive Isotope Distribution (A. V. Lebedinskii and Y. I. Moskaalev, eds., Atomizdat, Moscow) 164-173 (1961) translated in AEC-tr-5265, 162171 NSA 16,26867

KOSHURNIKOVA, N. A., and V. K. Lemberg Long-term effects of aseptic inflammation in rats exposed to plutonium-239

In: Distribution, Biological Effects, and Rapid Excretion of

Radioactive Isotopes (Y. I. Moskalev, ed., Meditsina, Moscow)

237-242 (1964) translated in AEC-tr-7590, 251-256 NSA 19, 40381

KOSHURNIKOVA, N. A., V. K. Lemberg, A. P. Nifatov and A. A. Puzyrev Pneumosclerosis in rats after intratreacheal administration of soluble $239 \mathrm{Pu}$ compounds (in Russian)

Gig. Tr. Prof. Zabol. 11, 27-32 (1968) NSA 23, 31932

KOSHURNIKOVA, N. A., and E. R. Lyubchanskii

Influence of prophylactic inhalation of pentacin on the remote after effects of $239 \mathrm{Pu}$ inhalation

Med. Radiol. 14(9), 29-34 (1969) translated in AEC-tr-7172, 11 p. NSA 23, 50621

KOSHURNIKOVA, N. A., V. K. Lemberg and E. R. Lyubchanskii Remote aftereffects of inhalation of soluble $239 \mathrm{Pu}$ compounds In: Remote Aftereffects of Radiation Damage (Y. I. Moskalev, ed., Atomizdat, Moscow) 305-314 (1971) translated in AEC-tr-7387, 334343 PD 7, 2069

KOSHURNIKOVA, N. A., E. R. Lyubchanskii, R. A. Erokhin and A. A. Puzyrev

Effect of some drugs on the remote aftereffects of inhalation of soluble $239 \mathrm{Pu}$ compounds

In: Remote Aftereffects of Radiation Damage (Y. I. Moskalev, ed., Atomizdat, Moscow) 380-387 (1971) translated in AEC-tr-7387, 416424 PD 7, 2077

KOSHURNIKOVA, N. A., V. P. Aristov, V. K. Lemberg, G. S. Mushkacheva, M. G. Poplyko and I. A. Tseveleva

Mechanism of development of plutonium-induced pulmonary sclerosis Health Phys. 22, 753-754 (1972) NSA $\underline{26}, 38745$

KOSHURNIKOVA, N. A., M. G. Poplyko, R. A. Erokhin, and I. V. Iovlev Behavior of plutonium 239 and dynamics of morphological change in

rat lungs following chronic inhalation of a plutonium citrate complex In: Biological Effects of Radiation from External and Internal Sources (Y. I. Moskalev and V. S. Kalistratova, eds., Meditsina, Moscow) 248-257 (1972) translated in AEC-tr-7457, 368-380 NSA 30 10014 
KOSHURNIKOVA, N. A., and M. G. Poplyko

$72-\mathrm{KOS}-3$

Influence of additional pathogenic factors on long-term sequelae of injury due to inhalation of plutonium 239

In: Biological Effects of Radiation from External and Internal

Sources (Y. I. Moskalev and V. S. Kalistratova, eds., Meditsina,

Moscow) 276-279 (1972) translated in AEC-tr-7457, 407-411

NSA 30,9970

KOSHURNIKOVA, N. A., V. P. Aristov, V. K. Lemberg, G. S. Mushkacheva, 73-KOS

M. G. Poplyko and I. A. Tseveleva

Pathogenesis of plutonium pneumosclerosis (in Russian)

Arkh. Patol. 35(5), 48-54 (1973) NSA 28, 21714

KOSHURNIKOVA, N. A.

Long-term consequences of the inhalation of plutonium-239 in rabbits (Abstract)

Radiobiologiya 14, 464 (1974) translated in AEC-tr-7596, 195

KOSHURNIKOVA, N. A., and E. R. Lyubchanskii

Osteosarcomogenic effectiveness of products of hydrolysis of plutonium-239 tetrafluoride in rats in the case of intraperitoneal injection (Abstract)

Radiobiologiya 14, 465 (1974) translated in AEC-tr-7596, 196-197

KOSHURNIKOVA, N. A. See also: 69-ANT, 64-ERO, 66-ERO, 69-ERO, 71-ERO, 64-KUD, 62-LEM-3, 66-LEM, 74-LEV-2, 68-LYU, 69-LYU-2, 65-MOS, 66-MOS-2, 66-MOS-3, 74-POM, 74-TEA

KOTRAPPA, P.

Calculation of the burden and dose to the respiratory tract from continuous inhalation of a radioactive aerosol

Health Phys. 17, 429-432 (1969) NSA 23, 45760

KOTRAPPA, P., and 0. R. Moss

Production of relatively monodisperse aerosols for inhalation experiments by aerosol centrifugation

Hea1th Phys. 21, 531-535 (1971) NSA 25, 54982.

KOTRAPPA, P., C. J. Wilkinson and H. A. Boyd

Technology for the production of monodisperse aerosols of oxides of transuranic elements for inhalation experiments

Health Phys. 22, 837-843 (1972) NSA 26, 38421

KRAEVSKII, N. A., V. N. Streltsova and Y. I. Moskalev Some results of studying the blastomogenic effect of radioactive isotopes

Acta Unio Intern. Contra Cancrum 20, 1151-1154 (1964) NSA 19, 7026

74-KOS

$74-$ KOS -2

KRASNOSHYEKOVA, G. P. See: 74-LIK

KRAUSHAAR, J. J. See: 70-MAE

KRESLOV, V. V., and R. E. Libinzon

Behavior of $237 \mathrm{~Np}$ in the animal organism and some problems of its biological effects

Radiobiologiya 6 , 837-841 (1966) translated in AEC-tr-6775, 105-113

NSA 21, 34578

KRESLOV, V. $V$.

Influence of ${ }^{237} \mathrm{~Np}$ on the activity of certain enzymes of phosphorous metabolism

Radiobiologiya 8, 30-33 (1968) translated in AEC-tr-6950, 47-53

NSA 22,47471

$69-$ KOT

71-KOT

72-KOT

64-KRA

$66-K R E$

68-KRE 
KRESLOV, V. V., and G. S. Mushkacheva

Change in composition of rat blood as affected by ${ }^{237} \mathrm{~Np}$ (in Russian)

70-KRE

Ukr. Biokhim, Zh. 42, 488-493 (1970) NSA 25, 13346

KRESLOV, V. V. See also: 71-TSE

KRETNER, H. K. See: 68-NGY

KREY, P. W., D. Bogen and E. French

$62-K R P$

Plutonium in man and his environment

Nature 195, 263-265 (1962) NSA 16, 25171

KREY, P. W.

Atmospheric burnup of a $238 \mathrm{pu}$ generator

67-KRP

Science 158, 769-771 (1967) NSA 22, 4362

KREY, P. W. , and E. P. Hardy

Plutonium in soil around the Rocky Flats plant

Doc. HASL-235, 44 p. (1970) NSA 24, 46355

KREY, P. W.

Plutonium-239 contamination in the Denver area

Hea1th Phys. 26, 117-120 (1974) NSA 29, 15599

KREY, P. W. See also: 71-HAR, 72-HAR, 72-HAR-2, 73-HAR

KRISTOFFERSSON, H. See: 62-ULB

KRIVOLUTSKII, D. A., and M. N. Fedorova

Effect of soil heating by ${ }^{239} \mathrm{Pu}$ on field fauna

73-KRI

Z001. Zh. 52, 601-603 (1973) translated in ORNL-tr-2824 NSA 30,

15369 EP $\frac{-6}{6}, 71$

KRYUK, V.F. See: 71-KAV

KUBO, A. S., and D. J. Rose

Disposal of nuclear wastes

Science 182, 1205-1211 (1973)

73-KUB

KUDASHEVA, N. P., and N. A. Koshurnikova

Effect of additional pathological agents on the peripheral blood

of rats exposed to plutonium-239

In: Distribution, Biological Effects, and Rapid Excretion of

Radioactive Isotopes (Y. I. Moskalev, ed., Meditsina, Moscow)

217-224 (1964) translated in AEC-tr-7590, 230-237 NSA 19, 40338

KUDASHEVA, N. P.

The dynamics of changes of the morphological composition of the

peripheral blood in rats following $239 \mathrm{Pu}$ inhalation

Radiobiologiya 7, 900-905 (1967) translated in AEC-tr-6891, 169-177

NSA 22, 49503

KUDASHEVA, N. P.

On the state of the blood system in rats under inhalation affection by $239 \mathrm{Pu}$

In: Radioactive Isotopes and the Body (Y. I. Moskalev, ed., Meditsina, Moscow) (1969) translated in AEC-tr-7195, 347-353 NSA 25, 24324 
KUDASHEVA, N. P.

72-KUD

Changes in the dog's blood system following damage due to inhalation of americium 241

In: Biological Effects of Radiation from External and Internal Sources

(Y. I. Moskalev and V. S. Kalistratova, eds., Meditsina, Moscow) 312-

315 (1972) translated in AEC-tr-7457, 455-459 NSA 29, 10475;

30, 9971

KUDASHEVA, N. P. See also: 62-BOG, 70-BUL, 71-BUL-2, 72-BUL, 66-LEM

KUNZENDORF, H. See: 70-GJO

KUNZLE-LUTZ, M., D. Nolibe, G. Petavy and J. C. Rannaud

70-KUN

Retention and lung clearance of plutonium oxide. Structure of alveolar macrophages

Arch. Ma1. Prof. Med. Trav. Secur. Sociale 31, 185-196 (1970)

translated in LF-tr-46 NSA 24, 48384; 25, 18891

KUUNZLE-LUTZ, M., H. Metivier, D. Nolibe, A. Simon-Vermot, J. L.

Gimbert and $P$. Jockey

Effects of lung washing on the retention of inhaled particles of plutonium oxide

Arch. Ma1. Prof. Med. Trav. Secur. Sociale 31, 513-516 (1970)

translated in LF-tr-53 NSA 25, 18895; 25, 42368

KUNZLE-LUTZ, M., H. Metivier, D. Nolibe, A. Simon-Vermot, J. L.

Gimbert and $P$. Jockey

Therapeutic pulmonary washing of plutonium oxide contaminations in the lung

Poumon Coeur 26, 1029-1038 (1970) translated in LF-tr-71 NSA 26, 9528

KUNZLE-LUTZ, M., H. Metivier, D. Nolibe, et al. Pulmonary lavage: Therapy of pulmonary contamination by plutonium oxide (in French)

J. Eur. Toxicol, 4(1), 53-59 (1971) NSA 26, 33828

KUNZLE-LUTZ, M. See also: 66-TRU, 66-TRU-2, 66-TRU-3

KUZMINA, E. A. See: 65-CHE 
LAFUMA, J.

Diagnosis and treatment of a local and afterwards generalized

63-LAF

plutonium contamination (in French)

In: Diagnosis and Treatment of Radioactive Poisoning (International

Atomic Energy Agency, Vienna) 381-386 (1963) NSA 17, 28639

LAFUMA, J., J. C. Nenot and M. Morin

New method for studying the efficiency of chelating agents of the

68-LAF

polyamino acid series for internal decontamination (in French)

Doc. CEA-R-3519 (EUR-3864 f), 21 p. (1968) NSA 22, 51564

LAFUMA, J.

Treatment of $23{ }^{9} \mathrm{Pu}$ contamination (in French)

70-LAF

Doc. CEA-CONF-1549, 14 p. (1970) NSA 24, 50863

LAFUMA, J., J. C. Nenot and M. Morin

Experimental research on the treatment of contamination by transplutonium elements

In: Radiation Protection Problems Relating to Transuranium

Elements (Doc. EUR-4612) 249-258 (1971) translated in LF-tr-60

NSA 25,8590

LAFUMA, J., J. C. Nenot and M. Morin

72-LAF

Problems of using urinary excretion data for evaluating body burden

In: Assessment of Radioactive Contamination in Man (International

Atomic Energy Agency, Vienna) 235-245 (1972) NSA 26, 56524

LAFUMA, J.

Inhaled radionuclides (in French)

Radioprotection $9(1), 15-25(1974)$ NSA 31, 14414

LAFUMA, J., J. C. Nenot, M. Morin, R. Masse, H. Metivier, D. Nolibe and $W$. Skupinski

Respiratory carcinogenesis in rats after inhalation of radioactive aerosols of actinides and lanthanides in various physicochemical forms

In: Experimental Lung Cancer. Carcinogenesis and Bioassays (E.

Karbe and J. F. Park, eds., Springer-Verlag, Berlin) 443-453 (1974)

LAFUMA, J.

Research on the biological effects of atmospheric pollutants (in French)

Bu11. Inform. Sci. Techn. (Paris) 191, 91-95 (1974) NSA 31, 26201

LAFIIMA, J. See al so: 70-BAI-5, 72-DUC, 68-MAP, 72-MET, 74-MET, 71MOR, 72-MOR, 73-MOR, 73-MOR-2, 73-MOR-3, 73-MOR-4, 74-MOR, 67-NEO, 70-NE0, 71-NEO-2, 71-NEO-3, 71-NEO-4, 71-NEO-5, 72-NEO, 72-NEO-2, 64-PIJ

LAGERQUIST, C. R., S. E. Hammond, E. A. Putzier and C. W.

$65-\mathrm{LAG}$

Piltingsrud

Effectiveness of early DTPA treatments in two types of plutonium exposures in humans

Health Phys. 11, 1177-1180 (1965) NSA 18, 43322

LAGERQUIST, C. R., I, B. Allen and K. L. Holman

Plutonium excretion following contaminated acid burns and prompt DTPA treatments

Health Phys. 13, 1-4 (1967) NSA 21, 6544

LAGERQUIST, C. R., E. A. Putzier and C. W. Piltingsrud Bioassay and body counter results for the first 2 years following an acute plutonium exposure

Health Phys. 13, 965-972 (1967) NSA 21, 41456 
LAGERQUIST, C. R., D. L. Bokowski, S. E. Hammond and D. B. Hylton

69-LAG

Plutonium content of several internal organs following occupational exposure

Am. Ind. Hyg. Assoc. J. 30, 417-421 (1969) NSA 23, 41307

LAGERQUIST, C. R., S. E. Hammond, D. L. Bokowski and D. B. Hylton Summary of the distribution of plutonium in the tissues of 12 occupationally exposed workers

Doc. RFP-1783, 14 p. (1971) NSA 30, 9992

LAGERQUIST, C. R., S. E. Hammond and D. B. Hylton Distribution of plutonium and americium in the body 5 years after an exposure via contaminated puncture wound

Health Phys. 22, 921-924 (1972) NSA 26, 38756

LAGERQUIST, C. R., S. E. Hammond, D. L. Bokowski and D. B. Hylton Distribution of plutonium and americium in occupationally exposed humans as found from autopsy samples

Doc. RFP-1849, 11 p. (1972) NSA 27, 22797

LAGERQUIST, C. R., S. E. Hammond, D. L. Bokowski and D. B. Hyl ton Distribution of plutonium and americium in occupationally exposed humans as found from autopsy samples

Health Phys. 25, 581-584 (1973) NSA 29, 5365

LAGERQUIST, C. R. See a1so: 68-HAS, 70-J0L-2, 72-J0L-2, 73-NOR, 65-PUT

LAIDLER, J. J. See: 73-ADE

LANCET Editorial

Hot spots or hot lungs?

Lancet 2, 1238-1239 (1974) NSA 31, 23047

LANDOLT, R. R. See: 71-MEW, 71-MEW-3

LANGHAM, J. See: 62-LUS, 67-LUS, 68-RIC, 70-RIC

LANGHAM, W., and E. R. Russell

45-LAN

Excretion studies

In: Report of Conference on Plutonium (J. J. Nickson, ed.,

Doc. $\mathrm{CN}-3167)$ 27-45 (1945) EP S3, 293

LANGHAM, W. H., S. H. Bassett, P. S. Harris and R. E. Carter Distribution and excretion of plutonium administered intravenously to man

Doc. LA-1151 (1950)

LANGHAM, W., and R. E. Carter The relative physiological and toxicological properties of americium and plutonium

Doc. LA-1309, 57 p. (1951) NSA 10, 1200 EP $\underline{5}, 104-113$

LANGHAM, W. H. Determination of internally deposited radioactive isotopes from excretion analyses

Am. Ind. Hyg. Assoc. Quart. 17, 305-318 (1956) EP 588

LANGHAM, W. H.

Part V - Excretion methods - the application of excretion analyses to the determination of body burden of radioactive isotopes

Brit. J. Radiol. Supp1. 2, 95-113 (1957) 
LANGHAM, W. H.

Physiology and toxicology of plutonium-239 and its industrial

$59-L A N$ medical control

Health Phys. 2, 172-185 (1959) NSA 14, 3377

LANGHAM, W. H.

Radioisotope absorption and methods of elimination: Relative significance of portals of entry

In: Radioisotopes in the Biosphere (R. S. Caldecott and L. A.

Snyder, eds., Univ. of Minnesota) 489-513 (1960) NSA 14, 23876

EP S1, 847

LANGHAM, W. H., J. N. P. Lawrence, J. McClelland and L. H. Hempelmann

62-LAN The Los Alamos Scientific Laboratory's experience with plutonium in man

Health Phys. 8 , 753-760 (1962) NSA $\underline{17}, 10338$

LANGHAM, W. $H$.

Physiological properties of plutonium and assessment of body burden in man

In: Assessment of Radioactivity in Man, Vol. 2 (International Atomic

Energy Agency, Vienna) 565-581 (1964) NSA 18, 23825

LANGHAM, W. H., P. S. Harris and T. L. Shipman

Plutonium dispersal by accidental or experimental low-order detonation of atomic weapons

Doc. LA-1981 (Rev), 40 p. (1966) NSA 20, 13004

LANGHAM, W. H.

The problem of large-area plutonium contamination

Bur. Rad. Health Seminar Paper No. 002, 15 p. (1968) NSA 24, 29738

LANGHAM, W. H.

Biological considerations of nonnuclear incidents involving nuclear warheads

Doc. UCRL-50639 (1969) NSA 24, 29700

LANGHAM, W. H.

Technical and laboratory support [Thule incident]

USAF Nuclear Safety 65, (Part 2), Spec. Edition AFRP 122-1, pp. $36-41$ (1970) EP $46 \overline{7}$

LANGHAM, $W$. $H$.

Plutonium distribution as a problem in environmental science In: Proceedings of Environmental Plutonium Symposium (E. B. Fowler, et a1., eds., Doc. LA-4756) 3-11 (1971) PD $\underline{6}, 2202$

LANGHAM, W. H.

Biological implications of the transuranium elements for man Health Phys. 22, 943-952 (1972) NSA 26, 38758

LANGHAM, W. H., and J. W. Healy

Maximum permissible body burdens and concentrations of plutonium:

biological basis and history of development

In: Uranium-Plutonium-Transplutonic Elements (H. C. Hodge, J. N.

Stannard and J. B. Hursh, eds., Springer-Verlag, New York)

569-592 (1973) PD 8,1022

LANGHAM, W. H. See also: 47-CAR, 69-DEA, 60-FOR, 53-HEM, 73-HEM-2, 74-HEM

LANSIART, A. See: 67-BOU 
LANZ, H., K. G. Scott, J. Crowley and J. G. Hamilton

The metabolism of thorium, protoactinium and neptunium in the rat

46-LAH

Doc. MDDC-648, 18 p. (1946) ADD 1, 648

LANZ, H. See also: 46-CRJ

LARA SAENZ, D., and E. Ramos

Physiopathology of contamination by plutonium: Fundamental

73-LAD

concepts (in Spanish)

Energ. Nuc1. (Madrid) 17, 261-282 (1973) NSA 30, 696

LARSON, H. V.

Factors in controlling personnel exposure to radiations from

external sources

In: Plutonium Handbook: A Guide to the Technology. Vol. 2 (0. J. Wick, ed., Gordon \& Breach, New York) 845-857 (1967) NSA 22, 8333

LARSON, H. V., C. E. Newton, Jr., W. V. Baumgartner, K. R. Heid

68-LAR

and G. H. Crook

Management of an extensive plutonium wound and the evaluation of

the residual internal deposition of plutonium

Phys. Med. Biol. 13, 45-53 (1968) NSA 22, 21544

LARSON, H. V. See also: 69-JEC, 68-NEW

LARSON, K. H.

Continental close-in fallout: Its history, measurement and characteristics

In: Radioecology (V. Schultz and A. W. Klement, Jr., eds.,

Reinhold, New York) 19-25 (1961) NSA 17, 33543 EP S1, 800

LARSON, K. H. See a1so: 65-NIS, 45-OLA, 63-0LA, 70-ROM

LAUER, G. J. See: 73-KNE

LAUREnS, P., A. Piwnica, C. Reidemeister, W. M. Chardack and A. A. Gage

Clinical results of the implantation of an isotopic pacemaker

In: Cardiac Pacing (H. J. Thalen, ed., Van Gorcum, Assen) 198-208

(1973) PD 8,1818

LAWRENCE, B. See: 46-FID, 46-SNR, 46-SNR-3

LAWRENCE, J. N. P.

Puqfua, an IBM 704 code for computing plutonium body burdens

Hea1th Phys. 8, 61-66 (1962) NSA 16, 28710

LAWRENCE, J. N. P.

Measurement of plutonium in humans

In: Plutonium Information Meeting for an Ad Hoc Subcommittee of

the Advisory Committee on Reactor Safeguards, Doc. CONF-740115, 79-86

(1974) NSA 31, 14402

LAWRENCE, J. N. P. See also: 74-J0L, 62-LAN

LEBEDINSKII, A. V., and Y. I. Moskalev (eds.)

Biological Effects of Radiation and Problems of Radioactive Isotope

Distribution, Atomizdat, Moscow, 342 p. (1961) translated in AEC-tr5265 NSA 18, 13396

LEBEDINSKII, A. V., and Y. I. Moskalev (eds.) Distribution, Biological Effects, and Migration of Radioactive Isotopes, Medgiz, Moscow, 344 p. (1961) translated in AEC-tr-7512 
LEBEDINSKII, A. V., and Y. I. Moskalev (eds.)

$62-L E B$

Plutonium-239: Its Distribution, Biological Effect and Accelerated

Elimination, Medgiz, Moscow (1962) translated in FTD-TT-63-559, and JPRS-16900 NSA 17, 12101 EP S3, 516

LEBEL, J. L., E. H. Bul1, J. L. Johnson and R. L. Watters Lymphosarcoma associated with nodal concentration of plutonium in dogs

Amer. J. Vet. Res. 31, 1513-1516 (1970) NSA 24, 41976

LEBEL, J. L.

A study of the translocation of plutonium and americium from wounds Doc. C00-1787-25, 218 p. (1974) NSA 31, 8973

LEBEL, J. L. See also: 72-BIS, 75-DAG, 75-DAG-2, 72-GOM, 74-GDM, 70-JOL, 72-JOL-2, 72-WAR

LEDGERW00D, R. M. See: 71-HES

LEE, R. C. See: 69-NOM, 69-SAG

LEE, R. E. See: 72-BRO

LEIPUNSKII, 0. I., J. E. Konstantinov, C. A. Fedorov and 0. G. Scotnikova

Mean residence time of radioactive aerosols in the upper layers of the atmosphere based on fallout of high altitude tracers

J. Geophys. Res. 75, 3569-3574 (1970) NSA 24, 41441

LEMBERG, V. K., Z. M. Bukhtoyarova and A. P. Nifatov The distribution of plutonium in the liver and bones according to the data of histoautoradiography

In: Biological Effects of Radiation and Problems of Radioactive Isotope Distribution (A. V. Lebedinskij and Y. I. Moskalev, eds., Atomizdat, Moscow) 136-144 (1961) translated in AEC-tr-5265, 135143

NSA $\underline{16}, 9914 ; \underline{16}, 26720$

LEMBERG, V. K., and A. P. Nifatov

Microdistribution of plutonium in rabbit and rat liver

In: Plutonium-239: Its Distribution, Biological Effect and Accelerated Elimination (A. V. Lebedinskii and Y. I. Moskalev, eds., Medgiz, Moscow) 23-31 (1962) translated in FTD-TT-63-559, 25-38 NSA 17, 30272

LEMBERG, V. K., and Z. M Bukhtoyarova Histoautoradiography data on plutonium distribution in the bones of rat and rabbit

In: Plutonium-239: Its Distribution, Biological Effect and Accelerated Elimination (A. V. Lebedinskii and Y. I. Moskalev, eds., Medgiz, Moscow) 32-40 (1962) translated in FTD-TT-63-559, NSA 17, 30273

LEMBERG, V. K., N. A. Koshurnikova and K. N. Klyzhuk

Changes in the blood system of rabbit effected by plutonium-239

In: Plutonium-239: Its Distribution, Biological Effect and Accelerated Elimination (A. V. Lebedinski $i$ and $Y$. I. Moskalev, eds., Medgiz, Moscow) 92-102 (1962) translated in FTD-TT-63-559, 133-149 NSA 17,30251

LEMBERG, V. K.

Bone tumors in dogs exposed to plutonium-239

In: Distribution, Biological Effects, and Rapid Excretion of Radioactive Isotopes (Y. I. Moskalev, ed., Meditsina, Moscow) 243-250 (1964) translated in AEC-tr-7590, 257-265 NSA 19, 40382 
LEMBERG, V. K., N. A. Koshurnikova, A. P. Nifatov, Z. M.

$66-$ LEM

Bukhtoyarova and N. P. Kudasheva

Effect of additional pathological factors on the long-term

consequences of $239 \mathrm{Pu}$ poisoning

In: Distribution and Biological Effects of Radioactive Isotopes

(Y. I. Moskalev, ed., Atomizdat, Moscow) 383-391 (1966) translated

in AEC-tr-6944, 484-492 NSA 23, 22386

LEMBERG, V. K., and T. I. Levdik

Concerning pathologic anatomy of the affection with $237 \mathrm{~Np}$ (in

Russian)

Arkh. Patol. 30(12), 36-41 (1968) NSA 23, 26900

LEMBERG, V. K. See also: 64-BEL-2, 59-BUK, 68-BUK, 66-ER0, 69-ERO, 71-ERO, 64-KOS, 68-KOS, 71-KOS, 72-KOS, 73-KOS, 71-LEV, 71-LEV-2, 71-LEV-3, 72-LEV, 72-LEV-2, 74-LEV-2, 69-MOS-2, 71-RYS, 72-SOB

LEUZE, R. E.

Safety in plutonium handling

Nucl. Safety $5,392-396$ (1964) NSA 18, 43857

LEVDIK, T. I., V. K. Lemberg, L. A. Buldakov, E. R. Lyubchanskii

and V. M. Pesternikov

Biological effectiveness of $237 \mathrm{~Np}$

Radiobiologiya 11,747-753 (1971) translated in AEC-tr-7306,

160-168 NSA $\underline{2 \overrightarrow{6}}, 38760$

LEVDIK, T. I., V. K. Lemberg, R. A. Erokhin and L. A. Buldakov

Some characteristics of the biological effect and behavior of

$2{ }^{37} \mathrm{~Np}$ in the animal body after administering different isotope salts

In: Remote Aftereffects of Radiation Damage (Y. I. Moskalev, ed.,

Atomizdat, Moscow) 439-449 (1971) translated in AEC-tr-7387, 483-494

LEVDIK, T. I. , and V. K. Lemberg

Remote aftereffects of damage by $237 \mathrm{~Np}$

In: Remote Aftereffects of Radiation Damage (Y. I. Moskalev, ed., Atomizdat, Moscow) 449-456 (1971) translated in AEC-tr-7387, 495-502

LEVDIK, T. I., V. K. Lemberg, L. A. Buidakov, E. R. Lyubchanskij and V. M. Pesternikov

Biological effectiveness of $237 \mathrm{~Np}$

Health Phys. 22, 643-645 (1972) NSA 26, 38741

LEVDIK, T. I., V. K. Lemberg and E. R. Lyubchanskii

Dynamics of morphological changes and microdistribution of neptunium 237 in the rat lung following intratracheal administration of the isotope

In: Biological Effects of Radiation from External and Internal

Sources (Y. I. Moskalev and V. S. Kal istratova, eds., Meditsina, Moscow) 229-236 (1972) translated in AEC-tr-7457, 342-351 NSA 30,9965

LEVDIK, T. I.

Histopathology of neptunium-237 lesion after a single intake of the isotope into the organism (Abstract)

Radiobiologiya 14, 466 (1974) translated in AEC-tr-7596, 198

LEVDIK, T. I., L. A. Buldakov, V. K. Lemberg, A. P. Nifatov and

$71-L E V-2$

64-LEU

$71-L E V$

$68-L E M$

LEU

$71-L E V-3$

N. A. Koshurnikova

Pathological anatomy of $237 \mathrm{~Np}$ lesion in the case of chronic intake of the isotope into the animal organism (Abstract)

Radiobiologiya 14, 467 (1974) translated in AEC-tr-7596, 199 
LEVDIK, T. I., and L. A. Buldakov

75--LEV

rumors of soft tissues and internal organs induced by neptunium237 (in Russian)

Vop. Onkol. 22, 80-87 (1975) NSA 31,29967

LEVDIK, T. I. See also: 68-LEM, 72-LYU-2, 73-MOS-4

LIBINZON, R. Y., and V. V. Konstantinova

Effect of plutonium on nucleic acid metabolism in the liver and bone marrow of the rabbit

In: Plutonium-239: Its Distribution, Biological Effect and Accelerated

El imination (A. V. Lebedinski $i$ and $Y$. I. Moskalev, eds., Medgiz,

Moscow) 74-79 (1962) translated in FTD-TT-63-559, 104-112

NSA 17,30279

LIBINZON, R. Y., and V. V. Konstantinova Activity of tissue phosphatases in rats suffering from subacute or chronic plutonium injury

In: Plutonium-239: Its Distribution, Biological Effect and Accelerated

El imination (A. V. Lebedinskii and Y. I. Mcskalev, eds., Medgiz, Moscow) 80-85 (1962) translated in FTD-TT-63-559, 113-121 NSA 17 , 30455

LIBINZON, R. Y., and N. I. Elkina Effect of plutonium on the concentration of nucleic acids in the bone tissue of rabbits (in Russian)

vop. Med. Khim. 12, 487-492 (1966) NSA 22, 25971

LIBINZON, R. Y. See al so: 67-ELK-2, 58-KON, 59-KON, 66-KRE, 66-TSE, 68-TSE

LIIKALA, R. C.

Radioisotope composition of plutonium in the fuel cycle

In: Plutonium Information Meeting for an Ad Hoc Subcormittee of the

Advisory Committee on Reactor Safeguards, Doc. CONF-740115, 8-15

(1974) NSA 31, 13773

LIKHTAREV, I. A., G. V. Arkhangelskaya, A. I. Dobroskok, I. A.

Zvonova, N. F. Korelina, G. P. Krasnoshyekova, V. S. Repin and A.

P. Ushakova

Use of a specialized analog computer for the model of the metabolism of some radionuclides

In: Proc. Third Int. Cong. Int. Radiat. Prot. Assn. (W. S. Snyder,

ed., Doc. CONF-730901-P2) Vol. 2, 1358-1363 (1974) NSA 30, 27250

LIKHTAREVA, T. M. See: 74-DOE-2

LINDENBALIM, A., and J. Schubert

Sustained action of injected chelating agents

Nature 187, 575-576 (1960) NSA 14, 21222

LINDENBALIM, A., J. F. Markley and M. W. Rosenthal

Removal of plutonium from blood as a function of DTPA treatment

and of the physical state of the plutonium

Health Phys. 8, 695-697 (1962) NSA 17, 10327

LINDENBAUM, A., and $W$. Westfall

Colloidal properties of plutonium in dilute aqueous solution

74-LIR

$62-L I B-2$

66-LIB

nt. J. App 1. Radiat. Isotop. 16, 545-553 (1965) NSA 20, 1835

65-L IN 
LINDENBAUM, A., C. Lund, M. Smoler and M. W. Rosenthal Preparation, characterization and distribution in mouse tissue of graded polymeric and monomeric plutonium. Radiochemical and autoradiographic studies

In: Diagnosis and Treatment of Deposited Radionucides (H. A. Kornberg and W. D. Norwood, eds., Excerpta Medica Foundation, Amsterdam) 56-64 (1968) NSA 23, 24630

LINDENBAUM, A., M. W. Rosenthal and M. Smoler An autoradiographic study of the changes in distribution of polymeric plutonium in mouse tissues

In: Diagnosis and Treatment of Deposited Radionuclides ( $H$ : A. Kornberg and W. D. Norwood, eds., Excerpta Medica Foundation, Amsterdam) 65-72 (1968) NSA 23, 24631

LINDENBAUM, A., and C. J. Lund Alpha counting by liquid scintillation spectrometry: Plutonium-239 in animal tissues

Radiat. Res. $37,131-140$ (1969) NSA 23, 16328

LINDENBALM, A., and M. H. Smoler High-resolution autoradiography of intracellular plutonium

Science 165, 192-194 (1969) NSA 23, 35626

LINDENBAUM, A., and M. W. Rosentha 1 Deposition patterns and toxicity of plutonium and americium in liver

Health Phys. 22, 597-605 (1972) NSA 26, 38770

LINDENBAUM, A., and J. J. Russell

Autoradiographic determination of alpha activity by variable exposure to $239 \mathrm{Pu}$ and $241 \mathrm{Am}$ in mouse $1 \mathrm{iver}$

Health Phys. 22, 617-620 (1972) NSA 26, 38772

LINDENBAUM, A. See also: 73-BAX, 73-BAX-2, 62-MAR, 64-MAR, 64-RAH, 62-ROS, 64-ROS, 67-ROS, 68-ROS, 68-ROS-2, 69-ROS, 69-ROS-2, 72-ROS, 72-ROS-2, 73-ROS, 60-SCH, 61-SCH-2

LIPPERT, J. See: 70-GJO

LISCO, H., M. P. Finkel and A. M. Brues

Carcinogenic properties of radioactive fission products and of

68-LIN

$68-L I N-2$

$69-$ LIN plutonium

Radio1. 49, 361-363 (1947) BA 22, 10792 EP S2, 15

LISCO, H., and W. E. Kisieleski

The fate and pathologic effects of plutonium metal implanted into rabbits and rats

Am. J. Path. 29, 305-321 (1953) NSA $\underline{6}, 6290$

LISCO, H. Autoradiographic and histopathologic studies in radiation carcinogenesis of the lung

Lab. Invest. 8 , 162-170 (1959) NSA 13, 5245

LISC0, H. See also: 46-ABR, 47-BRM

LISTER, B. A. J., A. Morgan and R. J. Sherwood Excretion of plutonium following accidental skin contamination Hea] th Phys. 9, 803-815 (1963) NSA 17, 37044

LISTER, B. A. J. Some problems of radiological protection in plutonium areas (in Japanese)

Nippon Genshiryoku Gakkaishi 6, 666-669 (1964) NSA 19, 13683 
LISTER, B. A. J.

68-LIA

Early assessment of the seriousness of lung contamination by insoluble alpha and low energy beta emitting materials after inhalation exposure

In: Proceedings of the 1st International Congress of Radiation Protection. Part 2 (W. S. Snyder, et al., eds., Pergamon Press, Oxford) 1191-1198 (1968) NSA 23, 14178

LITTLE, C. A. See: 74-WHF

LITVINOV, N. N.

Morphological changes in bony tissues in acute and sub-acute injury due to plutonium

Med. Radiol. 4(5), 68-72 (1959) translated in JPRS-2860, 85-91

NSA $13,15890^{-}$

LIVERMAN, J. L.

Introductory testimony (part of the AEC presentation at EPA

Plutonium Standards Hearings, December 10-11, 1974)

In: Doc. WASH-1359, 1-10 (1974)

LIVSHITS, R. Y. See: 74-NEM

LLOYD, E., R. E. Rowland, D. Hodges and J. H. Marsha 11

Surface to volume ratios of bone determined by computer analys is of microradiographs

Nature 218, 365-366 (1968) NSA 22, 31003

LLOYD, E., and D. Hodges

Quantitative characterization of bone: A computer analys is of microradiographs

Clin. Orthopaedics, No. 78, July-Aug., 230-250 (1971) NSA 25, 21750

LLOYD, E., and J. H. Marshall

Toxicity of $239 \mathrm{Pu}$ relative to $226 \mathrm{Ra}$ in man and dog

In: Radiobiology of Plutonium (B. J. Stover and W. S. S. Jee, eds.,

J. W. Press, Salt Lake City) 377-383 (1972) NSA 26, 41303

LLOYD, E. See also: 73-MAJ, 69-ROL

LLOYD, R. D., C. W. Mays, W. Fisher and R. Hintze

$62-L O R$

Total body $r$-ray counting of $\mathrm{Pu}^{239}$ in beagles

Health Phys. 8, 777-780 (1962) BA 42, 20406

LLOYD, R. D., C. W. Mays, G. N. Taylor and D. R. Atherton

241 Am studies in beagles

Health Phys. 18, 149-156 (1970) NSA 24, 16953

LLOYD, R. D., C.W. Mays, G. N. Taylor and J. L. Williams

Cal ifornium excretion and retention by beagles injected with ${ }^{249} \mathrm{Cf}$ or $252 \mathrm{Cf}$

Health Phys. 22, 667-673 (1972) NSA 22, 38779

LLOYD, R. D., W. S. S. Jee, D. R. Atherton, G. N. Taylor and

C. W. Mays

$24 \mathrm{Am}$ in beagles: Biological effects and skeletal distribution

In: Radiobiology of Plutonium (B. J. Stover and W. S. S. Jee, eds., J. W. Press, Salt Lake City) 141-148 (1972) NSA 26, 41258

LLOYD, R. D., D. R. Atherton, C. W. Mays, S. S. McFarland and

$68-\mathrm{LOE}$

74-LIV

59-LIT

LIV 
LLOYD, R. D., J. G. Dockum, D. R. Atherton, C. W. Mays and

J. L. Williams

The early retention, excretion and distribution of injected

einsteinium citrate in beagles

Health Phys. 28, 585-589 (1975) NSA 32, 11853

LLOYD, R. D. See also: 72-ATH, 69-MAY, 72-MAY, 64-PEN

LOGAN, R., and R. Todd

Whole body counting of plutonium in rats

$68-L O G$

Int. J. App1. Radiat. Isotop. 19, 422-425 (1968) NSA 22, 51630

LOGAN, R. See also: 66-T0D, 68-TOD

LOHR, W. See: 47-ABR

LONDON, J. E. See: 68-RIC

LONG, A. B.

Plutonium inhalation: the burden of negligible consequence

$71-L O N$

Nucl. News 14(6), 69-73 (1971) NSA 25, 42508

LORENZ, E. See: 49-JA0

LOTZ, W. E. See: 65-DOS

LOUIE, B. J. See: 52-ASL-2

LOUTIT, J. F. See: 74-BLM

LOVBORG, L. See: 70-GJ0

LOW-BEER, A. de G.

Bioassay of plutonium

73-LOW

In: Uranium-Plutonium-Transplutonic Elements (H. C. Hodge, J. N.

Stannard and J. B. Hursh, eds., Springer-Verlag, New York)

593-611 (1973) PD 8, 1023

LOW-BEER, A. de G.

Bioassay of transplutonium elements

73-LOW-3

In: Uranium-Plutonium-Transplutonic Elements (H. C. Hodge, J. N.

Stannard and J. B. Hursh, eds., Springer-Verlag, New York)

909-928 (1973) PD 8, 127T

LOW-BEER, A. de G. See also: 62-PAH, 72-PAH

LUCAS, H. F., Jr. SEe: 73-ROL

LUDWIEG, F. See: 62-KLO

LUND, C. J. See: 68-LIN, 69-LIN

LUSHBAUGH, C. C., and J. Langham

A dermal lesion from implanted plutonium

Arch. Dermatol. 86, 461-464 (1962) NSA 17, 7814

LUSHBAUGH, C. C., R. J. Cloutier, G. Humason, J. Langham and

$62-$ LUS

S. Guzak

Histopathologic study of intradermal plutonium metal deposits:

Their conjectured fate

Ann. N. Y. Acad. Sci. 145, 791-797 (1967) NSA 23, 26931

LUSHBAUGH, C. C. See also: 56-FOR

LUTZ, D. See: 68-SHL 
LUTZ, M., D. Nolibe, G. Petavy and J. Rannaud

70-LUT Contribution to the study of pulmonary retention and disposal

of plutonium oxide. Ultrastructural study of alveolar macrophages Arch. Ma 1. Prof. Med. Trav. Secur. Sociale Paris, 31, 185-196

(1970) translated in LF-tr-46 NSA 25, 18891

LUTZ, M. See also: 70-KUN, 70-KUN-2, 70-KUN-3, 71-KUN, 66-TRU, 66TRU-2, 66-TRU-3

LUYSTERBORG, J. See: 71-DUL

LYAGINSKAYA, A. M., and E. P. Ovcharenko

Effect of ${ }^{241} \mathrm{Am}$ on the histopathology of the ovaries in rats

In: Remote Aftereffects of Radiation Damage (Y. I. Moskalev, ed., Atomizdat, Moscow) 415-421 (1971) translated in AEC-tr-7387, 455-

462 PD $\underline{7}, 354 T$ EP S3, 164

LYAGINSKAYA, A. M.

Estimation of permissible radiation doses from ${ }^{131} \mathrm{I},{ }^{90} \mathrm{Sr}$, HTO, and $241 \mathrm{Am}$ to the gonads

In: Health Physics Probiems of Internal Contamination (E. Bujdoso, ed., Akademiai Kiado, Budapest) 181-184 (1973) NSA 28, 30275

LYAGINSKAYA, A. M. See also: 69-MOS-4, 72-OVC-4

LYNCH, 0. D. T., Jr. See: 75-GUD

LYNN, J. C. See: 73-HOE, 73-SCG, 74-SCG, 71-WAF

LYUBCHANSKII, E. R. Behavior of a citrate complex of plutonium-239 in rats after inhalation

In: Distribution, Biological Effects, and Rapid Excretion of

Radioactive Isotopes (Y. I. Moskaiev, ed., Meditsina, Moscow)

35-41 (1964) translated in AEC-tr-7590, 34-41 NSA 19, 40316

LYUBCHANSKII, E. R.

Behavior of plutonium-239 citrate in rats after single and repeated intraperitoneal injection of the isotope

In: Distribution, Biological Effects, and Rapid Excretion of

Radioactive Isotopes (Y. I. Moskalev, ed., Meditsina, Moscow)

117-123 (1964) translated in AEC-tr-7590, 124-130 NSA 19, 40326

LYUBCHANSKII, E. R.

The use of pentacinium for the removal of $239 \mathrm{Pu}$ from the organs of rats in inhalation affection (in Russian)

Med. Radiol. 10(1), 45-49 (1965) NSA 19, 17475

LYUBCHANSKII, E. R., and L. A. Buldakov

On the experimental substantiation of the maximum permissible content of $23{ }^{9} \mathrm{Pu}$ in the human organism and in the air of work premises

In: Distribution and Biological Effects of Radioactive Isotopes

(Y. I. Moskalev, ed., Atomizdat, Moscow) 435-461 (1966) translated

in AEC-tr-6944, 548-580 NSA 23, 22270

LYUBCHANSKII, E. R.

Using $\mathrm{Na}_{3} \mathrm{CaDTPA}$ (Pentacin) to eliminate ${ }^{239} \mathrm{Pu}$ from the organism of the rat with inhalation poisoning

In: Distribution and Biological Effects of Radioactive Isotopes

(Y. I. Moskalev, ed., Atomizdat, Moscow) 471-476 (1966) translated

in AEC-tr-6944, 592-598 NSA 23, 22271

71-LYA

73-LYA

64-LYU

64-LYU-2

65-LYU

66-LYU

66-LYU-2 
LYUBCHANSKII, E. R.

$67-L Y U$

The behavior of ${ }^{239} \mathrm{Pu}$ in rats after a single inhalation of some of its chemical compounds

Radiobiologiya 7, 541-547 (1967) translated in AEC-tr-6889, 84-96

NSA 22, 14954

LYUBCHANSKII, E. R., and N. A. Koshurnikova

Use of the DTPA aerosol (diethylene triamine pentaacetic acid) for

$68-L Y U$ prophylaxis of rats chronically inhaling $239 \mathrm{Pu}$ (in Russian)

Med. Radiol. 10(13), 46-52 (1968) NSA 23, 8039

LYUBCHANSKII, E. R.

Behavior of a citrate complex of ${ }^{239} \mathrm{Pu}$ in the body of rats after stopping chronic inhalation

In: Radioactive Isotopes and the Body ( $Y$. I. Moskalev, ed.,

Meditsina, Moscow) (1969) translated in AEC-tr-7195, 153-160

NSA 25,23965

LYUBCHANSKII, E. R., Z. M. Bukhtoyarova and N. A. Koshurnikova Behavior of $239 \mathrm{Pu}$ and the histological picture of injury of the skeleton and liver of rats under single and chronic intake of the i sotope

In: Radioactive Isotopes and the Body (Y. I. Moskalev, ed., Meditsina, Moscow) (1969) translated in AEC-tr-7195, 376-387 NSA 25, 23986

LYUBCHANSKII, E. R.

Behavior and character of microdistribution of $239 \mathrm{Pu}$ in the rat organism in chronic inhalation of its citrate complex (in Russian)

Gig. Tr. Prof. Zabol. 13(Mar), 39-42 (1969) NSA 24, 25370

LYUBCHANSKII, E. R.

Behavior and nature of the microdistribution of plutonium-239 in the rat organism after chronic inhalation of its soluble compounds

Radiobiologiya 12, 272-278 (1972) translated in AEC-tr-7362, 170-

180 NSA $27,2 \overline{840}$

LYUBCHANSKII, E. R., and T. I. Levdik

Neptunium 237 metabolism after inhalation thereof

In: Biological Effects of Radiation from External and Internal Sources

(Y. I. Moskalev and V. S. Kalistratova, eds., Meditsina, Moscow)

204-214 (1972) translated in AEC-tr-7457, 309-321 NSA 30, 10012

LYUBCHANSKII, E. R., and A. P. Nifatov

Americium 241 metabolism after inhalation

In: Biological Effects of Radiation from External and Internal Sources

(Y. I. Moskalev and V. S. Kalistratova, eds., Meditsina, Moscow)

279-291 (1972) translated in AEC-tr-7457, 412-426 NSA 30, 10015

LYUBCHANSKII, E. R. See also: 69-ANT, 69-BUL, 70-BUL, 71-BUL-2,

64-ERO, 66-ERO, 69-KOS, 71-KOS, 71-KOS-2,

74-KOS-2, 71-LEV, 72-LEV, 72-LEV-2

LYUBIMOVA-GERASIMOVA, R. M. See: 74-MOS, 74-SEA, 72-ZAL-2 
MADHVANATH, U., S. S. Murthy, R. R. Vishwakarma, P. Subrahmanyam

74-MAD and G. C. Das

Alpha contamination of the skin: Dose and LET distribution at depths corresponding to the epidermal thickness of skin

Hea7th Phys. 27, 469-474 (1974) NSA 31, 16864

MAGEE, M. See: 53-FOR

MAGNO, P. J., P. E. Kauffman and B. Shleien

Plutonium in environmental and biological media

Health Phys. 13, 1325-1330 (1967) NSA 22, 28500

MAGNO, P. J., P. E. Kauffman and P. R. Groulx

$239 \mathrm{Pu}$ in human tissues and bone

Radio1. Health Data Rep. 10, 47-50 (1969) NSA 23, 45756

MAGNO, P. J. See also: 67-KAU, 67-SHL, 70-SHL, 70-SHL-2

MAHLUM, D. D., J. L. Palotay and W. J. Clarke

Effect of internal emitters on liver tumours induced by dimethylaminoazobenzene

Nature 206, 945-946 (J965) NSA 19, 31854

MAHLUM, D. D., and W. J. Clarke

$237 \mathrm{~Np}$ toxicity in the rat - I. Histopathologic and chemical

66-MAH observations in liver and kidney

Health Phys. 12, 7-13 (1966) NSA 20, 8566

MAHLUM, D. D.

Neptunium-237 toxicity in the rat II. Intracellular distribution of neptunium and cerium in rat 1 iver

Toxicol. App1. Pharmacol. 11, 264-271 (1967) BA 50, 13911

MAHLUM, D. D., and M. R. Sikov

Skeletal changes produced by the administration of ${ }^{239} \mathrm{Pu}$ and

$144 \mathrm{Ce}$ to weanling rats

In: Radiation Biology of the Fetal and Juvenile Mammal (M. R, Sikov

and D. D. Mahlum, eds., Doc. CONF-6905i) 567-576 (1969) NSA 24,

23084

MAHLUM, D. D., and M. R. Sikov

Physicochemical state as a determinant of $238 \mathrm{Pu}$ toxicity in the rat

Hea1th Phys. $\underline{17}, 346-347$ (1969) NSA 23, 47927

MAHLUM, D..D.

Modification of the hepatotoxic action of $237 \mathrm{~Np}$ in the rat

67-MAG

69-MAG

Toxicol. App1. Pharmaco1. 18, 696-702 (1971) NSA 26, 33800

MAHLUM, D. D., and M. R. Sikov Distribution and toxicity of monomeric and polymeric ${ }^{239} \mathrm{Pu}$ in immature and adult rats

Radiat. Res. 60, 75-88 (1974) NSA 31, 909

MAHLUM, D. D. See also: 70-BEJ, 74-CRD, 72-HUF, 72-KAS, 68-SIK, 68-SIK-2, 72-SIK, 72-SIK-2

MAHONY, T. D. See: 72-NEL-2, 68-NEW, 68-SIK-2, 74-SUL

MAISIN, J. R.

Metabolism and toxicity of plutonium (in French)

J. Belge Radiol. 51, 274-283 (1968) NSA 23, 9849

68-MAI

MAJOR, D. See: 73-NIA

MALVICINI, A. See: 68-DEB 
MAMUIRO, T., and T. Matsunami

Alpha-activity of highly radioactive fallout particles

67-MAT

Health Phys. 13, 51-59 (1967) NSA 21, 6038

MAMURO, T., and T. Matsunami

69-MAT

Plutonium-238 in fallout

Science 163, 465-467 (1969) NSA 233, 33273

MANN, J. R., and R. A. Kirchner

Evaluation of lung burden following acute inhalation exposure to

67-MAN

highly insoluble $\mathrm{PuO}_{2}$

Health Phys. 13, 877-882 (1967) NSA 21, 39415

MANN, J. R. See also: 70-ANH, 67-B0S, 68-HAS, 65-PUT

MANQUENE, J. See: 64-PIJ

MARCHIONNI, V. See: 71-TES

MARKLEY, J. F., M. W. Rosenthal and A. Lindenbaum

Comparative studies on the remova? of monomeric and polymeric plutonium by DTPA (Abstract)

Health Phys. 8, 739 (1962) EP 647

MARKLEY, J. F.

Removal of polymeric plutonium from mice by combined therapy

with the calcium chelate and penta-ethyl ester of DTPA

Intern. J. Radiat. Biol. , 405-407 (1963) NSA 18, 23369

MARKLEY, J. F., M. W. Rosenthal and A. Lindenbaum

Distribution and removal of monomeric and polymeric plutonium

in rats and mice

Intern. J. Radiat. Biol. 8, 271-278 (1964) NSA 19, 12926

MARKLEY, J. F. See also: 62-LIN, 62-ROS

MARKS, E. K. See: 49-JAO

MARKS, S. See: 68-NEW, 62-PAR, 59-TEM, 60-TEM, 58-THO

MARLOW, C. G. See: 69-SMH

MARSHALL, J. H.

The retention of radionuclides in bone

In: Delayed Effects of Bone-Seeking Radionuclides (C. W. Mays,

et al., eds., Univ. of Utah Press, Salt Lake City) 7-27 (1969)

NSA 23,38428

MARSHALL, J. H. , and E. Lloyd

The effect of the remodelling of bone upon the relative toxicities

73-MAJ

of radium and plutonium in man and dog

In: Radionuclide Carcinogenesis (C. L. Sanders, et a1., eds.,

Doc. CONF-720505) 421-436 (1973) NSA 28, 18538

MARSHALL, J. H. See also: 68-LOE, 72-LOE, 68-ROS

MARTELL, E. A., P. A. Golden, J. J. Kraushaar, D. W. Shea and

62-MAR

63-MAR

64-MAR

R. H. Williams

Fire [Rocky Flats Plant]

Environment $12(4), 14-20(1970) \quad$ EP S1, 75

MARTELL, E. A. See also: 72-POE, 74-POE

MASI, G. See: 71-TES 
MASSE, $R$.

Comparative cytological study of the effect of inhaled plutonium and silica on the behavior of the alveolar macrophage (in French)

In: Inhaled Particles III (W. H. Walton, ed., Unwin Bros. Ltd., 01d Woking, England) 247-257 (1971) NSA 26, 12509

MASSE, R. See also: 74-LAF-2, 72-MET, 74-MET, 67-NEO, 72-NEO

MASSEY, P., and J. Lafuma

In vitro binding of plutonium to human transferrin and competition

68-MAP reaction with ferric ions (in French)

Doc. CEA-R-3623, 17 p. (1968) NSA 23, 9830

MASSEY, P. See also: 71-NEO-5

MATLACK, G. M.

Chemistry of plutonium in relation to its behavior in biological and environmental systems

In: Plutonium Information Meeting for an Ad Hoc Subcomittee of the

Advisory Committee on Reactor Safeguards, Doc. CONF-740115, 2-7 (1974)

NSA 31,13772

MATSUNAMI, T. See: 67-MAT, 69-MAT

MATSUOKA, 0., K. Yoshikawa and T. Fukumoto An application of ultra high speed $\alpha$-autoradiography in the detection of $239 \mathrm{Pu}$ skin surface contamination

Hoken Butsuri 2, 121-127 (1967) translated in NSJ-tr-136 NSA 23, 4931

MATSUOKA, 0., M. Kashima and $H$. Joshima The general rule which influences the behaviour of the radioactive particles in the body and its application to the plutonium metabolism In: Final Report of Research Project on Plutonium Hazards, April 1966 March 1970 (M. Suzuki, et a 1., eds., Doc. NIRS-Pu-8) 25-28 (1971)

PD 6, 1571 EP S1, 521

MATSUOKA, 0., H. Joshima and M. Kashima Distribution of plutonium following inhalation of plutonium nitrate

In: Final Report of Research Project on Plutonium Hazards, April

1966 - March 1970 (M. Suzuki, et al., eds., Doc. NIRS-Pu-8) 36-38

(1971) PD 6,1574

MATSUOKA, O., H. Joshima, M. Kashima and Y. Noda Acute toxicity of plutonium in mice

In: Final Report of Research Project on Plutonium Hazards, April

1966 - March 1970 (M. Suzuki, et al., eds., Doc. NIRS-PU-8) 44-

47 (1971) PD $\underline{6}, 1576$ EP S1, 526

MATSUOKA, O., M. Kashima, H. Joshima and $Y$. Noda

Whole-body autoradiographic studies on plutonium metabolism as affected by its physicochemical state and route of administration Health Phys. 22, 713-722 (1972) NSA 26, 38786

MATSUKOA, 0. See also: 70-BAI-5, 71-EN0, 71-JOS, 71-KAS, 75-KAS, $71-S U Z$

MATVEEV, V. I.

Dose administration of radioactive aerosols to dogs (in Russian)

71-MAO

Gig. Sanit. 1971(5), 69-72 (1971) PD ], 1218

MATVEeV, V. I. See also: 72-BUL, 72-NIF

MAUIDERLY, J. L. See: 72-THR-2

MAUSHART, R. See: 64-EHR, 62-KIE, 68-KIE 
MAXWELL, R. E. See: 69-BED, 72-NAB

MAY, H. A. See: 72-RUN

MAYS, C. W., T. F. Dougherty, G. N. Taylor, R. D. Lloyd, B. J.

69-MAY

Stover, W. S. S. Jee, W. R. Christensen, J. H. Dougherty and

D. R. Atherton

Radiation-induced bone cancer in beagles

In: Delayed Effect of Bone-Seeking Radionuclides (C. W. Mays, et al., eds., Univ. of Utah Press, Salt Lake City) 387-408 (1969)

NSA 23,38800

MAYS, C. W., G. N. Taylor, W. S. S. Jee and T. F. Dougherty Speculated risk to bone and liver from ${ }^{239} \mathrm{Pu}$

Heal th Phys. 19, 601-610 (1970) NSA 25, 11301

MAYS, C. W., and R. D. Lloyd Bone sarcoma incidence vs. alpha particle dose

In: Radiobiology of Plutonium (B. J. Stover and W. S. S. Jee, eds.,

J. W. Press, Salt Lake City) 409-430 (1972) NSA 26, 41231

MAYS, C. W., and T. F. Dougherty

Progress in the beagle studies at the University of Utah

Health Phys. 22, 793-801 (1972) NSA 26, 38793

MAYS, C. W. See also: 72-BUS, 62-DOT, 69-D0T, 62-L0R, 70-LOR, 72-LOR, 72-LOR-2, 74-LOR, 75-LOR, 64-PEN, 62-REH, 62-STB-1, 72-TAG, 73-THU

McCARLEY, W. T. See: 61-KIN

MCCLANAHAN, B. J., and H. A. Kornberg Treatment of plutonium-contaminated wounds with diethylenetriaminepentaacetic acid in rats

In: Diagnosis and Treatment of Deposited Radionuclides

(H. A. Kornberg and W. D. Norwood, eds., Excerpta Medica

Foundation, Amsterdam) 395-402 (1968) NSA 21, 36568; 23, 24547

McCLANAHAN, B. J. See also: 61-BAl-2, 68-SMV

MCCLEAREN, H. A. See: 72-JOY

MCCLELLAN, R. O., H. W. Casey and L. K. Bustad Transfer of some transuranic elements to milk Health Phys. $\underline{8}, 689-694$ (1962) NSA 17,10326

McCLELLAN, R. O., L. K. Bustad, W. J. Clarke, N. L. Dockum, 70-MAY

J. R. MCKenney and H. A. Kornberg

Bone-seeking radionuclides in miniature swine

In: Some Aspects of Internal Irradiation (T. F. Dougherty,

et a1., eds., Pergamon Press, Oxford) 341-348 (1962) NSA 17,

13955 EP S3, 197

MCCLELLAN, R. 0.

Use of swine in radionuclide toxicity studies

In: Swine in Biomedical Research (L. K. Bustad and R. 0. McClellan, eds., Frayn Ptg. Co., Seattle) 447-462 (1966) BA 4, 117631

MCCLELLAN, R. 0 .

Progress in studies with transuranic elements at the Lovelace Foundation

Heal th Phys. 22, 815-822 (1972) NSA 26, 38795 
McCLELLAN, R. 0., H. A. Boyd, A. F. Gallegos and R. G. Thomas Retention and distribution of $244 \mathrm{Cm}$ following inhalation of $24{ }^{4} \mathrm{CmCl}_{3}$ and ${ }^{244} \mathrm{CmO}_{1} 73$ by beagle dogs

Health Phys. 22, 877-885 (1972) NSA 26, 38800

MCCLELLAN, R. 0. See also: 71-BRA, 72-BRA, 74-BRA, 62-BUS, 68-BUS, 72-BUS, 63-CAH, 72-MCK, 72-MEW, 72-THR-2

McCLELLAND, J. See: 62-LAN

MCCONNON, D.

Use of $235 \mathrm{~Np}$ for the calibration of plutonium lung counters

70-MCO

Int. J. Appl. Radiat. Isotop. 21, 744-747 (1970) NSA 25, 21402

MCFARLAND, S. S. See: 74-LOR

MCHENRY, R. E.

${ }^{244} \mathrm{Cm}$ : A radioisotopic power fuel

Doc. CONF-720519-1, 17 p. (1972) NSA 26, 38581

MCINROY, J.F. See: 73-CAM

MCKAY, L. R., A. L. Brooks and R. 0. McClellan Retention, distribution, dose, and cytogenetic effects of ${ }^{241} \mathrm{Am}$

72-MCK citrate in the Chinese hamster

Health Phys. 22, 633-640 (1972) NSA 26, 38775

McKAY, L. R. See also: 71-BRA

MCKEE, R. W.

Public radiation exposure from $238 \mathrm{Pu}$-fueled artificial hearts

73-MCW

In: Doc. WASH-1220, 45-46 (1973) PD 7, 4280

MCKENNEY, J. R. See: 62-MCR-2

MCLEAN, A. S. See: 56-FAD

MCLENDON, H. R.

Soil monitoring for plutonium at the Savannah River plant

75-MCL Hea 1 th Phys. 28, 347-354 (1975) NSA 32, 3493

MCSWEENEY, T. I. See: 73-SEL

MEIER, D. M. See: 73-SAN-3

METCALF, R. G. See: 50-BOY, 50-BOY-2

METIVIER, H., D. Nolibe, R. Masse and J. Lafuma Cancers caused in baboons (Papio papio) by inhalation of $\mathrm{PuO}_{2}$

$72-\mathrm{MCH}$ (in French)

C. R. Acad. Sci., Ser. D, 275, 3069-3071 (1972) translated in

LF-tr-80 NSA 28, 2979; $\underline{29}, 814$

METIVIER, $H$.

A contribution to the study of tetravalent plutonium hydrolysis and complexation by acids of biological interest (Thesis)

DOC. CEA-R-4477, 88 p. (1973)

METIVIER, H., D. Nolibe, R. Masse and J. Lafuma

Excretion and acute toxicity of $239 \mathrm{PuO}_{2}$ in baboons

Health Phys. 27, 512-514 (1974) NSA 31, 20099

METIVIER, H. See also: 70-KUN-2, 70-KUN-3, 71-KUN, 74-LAF-2, 66-TRU-3 
MEWHINNEY, J. A., P. L. Ziemer and R. R. Landolt

Retention and distribution of injected ${ }^{252} \mathrm{Cf}$ in the rat

71-MEW

Health Phys. 21, 857-859 (1971) NSA 26, 9463

MEWHINNEY, J. A.

Fate of $252 \mathrm{Cf}$ in the rat (Thesis, Purdue Univ.)

71-MEW-2

University Microfilms Order No. 71-20, 506, 129 p. (1971)

NSA 25,57922

MEWHINNEY, J. A., P. L. Ziemer and R. R. Landolt

${ }^{252} \mathrm{Cf}$ distribution in rat tissue and bone

In: Contamination by Bone-Seeking Radionuclides and Radioprotection

(Societe Francaise de Radioprotection, Montrouge, France) 264-296

(1971) NSA 26, 25924

MEWHINNEY, J. A., A. L. Brooks and R. 0. McClellan Comparison of the retention and distribution of injected ${ }^{252} \mathrm{Cf}$ in rats and Chinese hamsters

Health Phys. 22, 695-700 (1972) NSA 26, 38784

MEWHINNEY, J. A. See also: 72-BRA

MEYER, D. D. See: 58-SCF

MICAL, R. S. See: 62-JEW-3

MICHELS, D. E.

Log-normal analys is of data for plutonium in the outdoors

In: Proceedings of Environmental Plutonium Symposium (E. B. Fowler, et al., eds., Doc. LA-4756) 105-111 (1971) PD $\underline{6}, 2212$

MICHELS, D. E. Plutonium fallout in the great plains relative to latitude and rainfal1

Doc. RFP-1960, 24 p. (1972) PD 7, 3930

MICHELS, D. E.

Plutonium plant safety

Science 177, 208-209 (1972) PD 7, 1199

MICHELS, D. E.

Diagnosis of plutonium reentrained in air

71-MEW-3

Doc. RFP-1927, 16 p. (1973) NSA 27, 24594

MICHELSON, I., J. C. Thompson, Jr., B. W. Hess and C. L. Comar Radioactivity in total diet

J. Nutr. $\underline{78}, 371-383$ (1962) NSA 17, 7767

MIETTINEN, J. K. See: 74-MUH, 74-TUL

MILLER, C. L., J. G. Payne, Jr., E. W. Bretthauer and A. A. Moghissi Transfer of plutonium from milk into cheese

Health Phys. 22, 563-565 (1972) NSA 26, 38767

MILLER, J. E. See: 69-HOJ

MILLIGAN, M. F. See: 72-CAM, 73-CAM, 71-FOW

MILLS, W. A.

Transuranics in the environment: The EPA perspective

$71-M I C$

72-MEW

72-MIC-2

73-MIC

62-MIH

In: Sixth Annual National Conference on Radiation Control: New

Challenges, Doc. DHEW/FDA-75-8010, 199-214 (1974) NSA 31, 20094

MINTO, W. L. See: 50-BOY, 50-BOY-2 
MISHIMA, $]$.

A review of research on plutonium releases during overheating

64-MIS and fires

Doc. HW 83668 (1964) NSA 19, 20200

MISHIMA, J., and L. C. Schwendiman Amount and characteristics of plutonium made airborne under thermal stress

In: Health Physics Aspects of Nuclear Facility Siting. Vol. 1

(P. G. Voilleque, ed., Idaho Falls) 198-207 (1971) NSA 25, 54546

MISHIMA, J. See also: 68-SCL, 73-SEL

MITOLA, J, See: 67-MOP

MIYAKE, Y., and K. Katsuragi

Deposition of plutonium in Tokyo through the end of 1966

Pap. Meteorol. Geophys. (Tokyo) 19, 267-276 (1968) NSA 23, 17578

MIYAKE, $Y_{.}$, and $Y$. Sugimura

Plutonium content in the Western North Pacific waters

Pap. Meteorol. Geophys. (Tokyo) 19, 481-485 (1968) NSA 23, 45422

MIYAKE, $Y ., Y$. Katsuragi and $Y$. Sugimura A study of plutonium fallout

J. Geophys. Res. $\underline{75}, 2329-2330$ (1970) NSA 24, 25142

MIYAKE, Y.

Environmental radioactive contamination and its chemical

analysis (in Japanese)

In: Studies on Radiation Effects (Y. Hiyama, ed., Tokyo Daigaku

Shuppankai) 27-109 (1971) NSA 27, 5244

MOEHRLE, G.

Medical considerations and guidelines on personnel decontamination

$68-M O E$

and decorporation. I. Personnel decontamination (in German)

Atompraxis 14, 69-73 (1968) NSA 22, 31093 PD $\underline{2}, 2411$

MOEHRLE, G.

Medical considerations and guidelines on personnel decontamination

and decorporation II. Decorporation (in German)

Atompraxis 14, 201-204 (1968) NSA 22, 38298

MOEHRLE, G.

Presently available methods for elimination of radioisotopes

from the body and their practical application (in German)

Strahlenschutz Forsch. Prax. 9, 67-73 (1969) NSA 25, 35134

68-MIY

$68-M I Y-2$

70-MIY

71-MIY

MOEHRLE, G. See also: 64-EHR, 71-KIE

MOGHISSI, A. A., and M. W. Carter

Comments on "Comparative distribution and excretion of $237 \mathrm{Pu}$ and

$239 \mathrm{Pu}$ nitrates in beagle dogs"

Health Phys. 28, 825-826 (1975) NSA 32,17577

MOGHISSI, A. A. See also: 72-MIL

MOKANU, 0. V. See: 70-ZLO

MOLDENHAWER, F.

Internal radiation burden from the radionuclides of world-wide

nuclear war fallout (in German)

In: Radiation Protection, Environment, and the Population

(Staatliche Zentrale fur Strahlenschutz, Berlin, German

Democratic Republic) 100-109 (1974) NSA 31, 8949 
MOLDOFSKY, P. J. See: 71-HUT, 72-SWI-2

MOLOKHIA, F. A. See: 73-NOM, 70-SAG

MORETTI, E. S. See: 73-BAX, 69-ROS. 72-ROS, 72-ROS-2, 73-ROS

MORGAN, A. See: 64-EAK, 63-LIB

MORGAN, K. Z.

72-MOK

Proper use of information on organ and body burdens of radioactive material

In: Assessment of Radioactive Contamination in Man (International

Atomic Energy Agency, Vienna) 3-23 (1972)

MORIN, M., J. C. Nenot and J. Lafuma

Experimental study of the evaluation of $239 \mathrm{Pu}, 241 \mathrm{Am}, 238 \mathrm{Pu},{ }^{242} \mathrm{Cm}$

$71-M 0 R$

body burdens using different methods of administration (in French)

In: Contamination by Bone-Seeking Radionuclides and Radioprotection

(Societe Francaise de Radioprotection, Montrouge, France) 297-314

(1971) NSA 26, 25925

MORIN, M. , J. C. Nenot and J. Lafuma

Metabolic and therapeutic study following administration to rats

of $238 \mathrm{Pu}$ nitrate - A comparison with $239 \mathrm{Pu}$

Health Phys. 23, 475-480 (1972) NSA $\underline{26}, 56556$

MORIN, M., J. C. Nenot and J. Lafuma

The behavior of $237 \mathrm{~Np}$ in the rat

Health Phys. 24, 311-315 (1973) NSA 27, 25065

MORIN, M., J. C. Nenot and J. Lafuma

Comparison of the biological behavior of californium with that of other transuranic elements (in French)

C. R. Acad. Sci. Paris, Ser. D, 276, 1209-1211 (1973) NSA 28,

15795

MORIN, M., W. Skupinski, J. C. Nenot and J. Lafuma

Experimental research on the treatment of contamination by actinide solutions

In: Health Physics Problems of Internal Contamination (E. Bujdoso,

ed., Akademiai Kiado, Budapest) 317-320 (1973) NSA 28, 30361

MORIN, M., J. C. Nenot and J. Lafuma

Californium: Study of its metabolism in relation to that of

other transuranic elements (in French)

Radioprotection 8 (1), 33-36 (1973) NSA 29, 10494

MORIN, M., J. C. Nenot and J. Lafuma

Distribution and removal by DTPA of injected $252 \mathrm{Cf}$ in the rat Health Phys. 26, 323-326 (1974) NSA 29, 29872

MORIN, M. See also: 68-LAF, 71-LAF, 72-LAF, 74-LAF-2, 70-NE0, 71-NE0-2, 71-NE0-3, 71-NE0-4, 71-NE0-5, 72-NE0,

$$
72-\mathrm{NE} 0-2
$$

72-MOR

73-MOR

73-MOR-2

73-MOR-4

MORK, H. M.

Redistribution of plutonium in the environs of the Nevada Test Site Doc. UCRL-12590, 29 p. (1970) EP S1, 668

MORK, H. M. See also: 70-ROM

MORLEY, F. See: 74-WEB 
MORROW, P. E., and L. J. Casarett

$61-M O P$

An experimental study of the deposition and retention of a plutonium239 dioxide aerosol

In: Inhaled Particles and Vapours (C. N. Davies, ed., Pergamon Press, New York) 167-175 (1961) NSA 15, 28978

MORROW, P. E., F. R. Gibb, H. Davies, J. Mitola, D. Wood, N. Wraight and H. S. Campbell

The retention and fate of inhaled plutonium dioxide in dogs

Health Phys. 13, 113-133 (1967) NSA 21, 14632

MORROW, P. E. See also: 68-CAS, 70-YUI

MORROW, W. G. See: 72-BAL-2

MORSY, S. M., F. M. El-Assāly and A. A. Aloush

Direct methods for the assessment of $23{ }^{9} \mathrm{Pu}$ and $235 \mathrm{U}$ body burdens

In: Assessment of Radioactive Contamination in Man (International

Atomic Energy Agency, Vienna) 115-127 (1972) NSA 26, 56522

MOSCATI, A. F., and R. C. Erdman

Possible effects of ionizing radiation upon marine life and some

implications of postulated accidental releases of radioactivity

Nuc1. Techno1. 22, 184-190 (1974) PD 8, 2512

MOSKALEV, Y. I.

Regularities in the distribution and toxicity of radioelements

Biofizika 3, 725-731 (1958) translated by Consultants Bureau,

$680-685$ NSA 14,7233

MOSKALEV, Y. I., L. A. Bu?dakov and V. N. Streltsova

Dependence of the biological action of plutonium upon the rhythm of its entry into the organism

Radiobiologiya 1, 250-256 (1961) translated in JPRS 11322 ,

297-315 NSA $1 \overline{6}, 6307$

MOSKALEV, Y. I., L. A. Buldakov and V. N. Streltsova

Effect of plutonium-239 on rat body

In: Plutonium-239: Its Distribution, Biological Effect and

Accelerated Elmination (A. V. Lebedinski $i$ and $Y$. I. Moskalev, eds., Medgiz, Moscow) 86-91 (1962) translated in FTD-TT-63-559, 122-132, and JPRS-16900, 9-22 NSA 17, 12102

MOSKALEV, Y. I.

Actual problems of the distribution of radioisotopes and the kinetics of their excretion (in Russian)

In: Diagnosis and Treatment of Radioactive Poisoning (International

Atomic Energy Agency, Vienna) 287-306 (1963) NSA 17, 28637

MOSKALEV, Y. I. (ed.)

Distribution, Biological Effects, and Rapid Excretion of Radioactive Isotopes, Meditsina, Moscow, 375 p. (1964) translated in AEC-tr-7590 NSA 19,3884

MOSKALEV, Y. I., L. A. Buldakov, N. A. Koshurnikova, A. P. Nifatov and G. N. Reshetov

Combined effects of ${ }^{90} \mathrm{Sr}, 144 \mathrm{Ce}$, and $239 \mathrm{Pu}$ on organs of rats

Radiobiologiya 5, 836-841 (1965) translated in AEC-tr-6603, 85-93

NSA 20, 10552

MOSKALEV, Y. I., and V. N Strel tsova

Radiation cancerogenesis and the problem of restoration (in Russian)

63-MOS

Med. Radiol. 10, 40-47 (1965) NSA 20, 22696

$65-M O S-2$ 
MOSKALEV, Y. I., and V. N. Streltsova

Radiocancerogenes is and the problem of restoration (in French)

$65-M O S-3$

Biol. Med. (Paris) 54, 428-439 (1965) NSA 21, 16486

MOSKALEV, Y. I. (ed.)

Distribution and Biological Effect of Radioactive Isotopes,

Atomizdat, Moscow, 575 p. (1966) translated in AEC-tr-6944

NSA 22, $8644 ; 24,39418$

MOSKALEV, Y. I., L. A. Buldakov, N. A. Koshurnikova, A. P. Nifatov

$66-M O S-2$

and G. N. Reshtov

Combined effect of ${ }^{90} \mathrm{Sr},{ }^{144} \mathrm{Ce}$, and ${ }^{239} \mathrm{Pu}$ on the rat organism (report 1)

In: Distribution and Biological Effect of Radioactive Isotopes

(Y. I. Moskalev, ed., Atomizdat, Moscow) 346-356 (1966) translated

in AEC-tr-6944, 441-452 NSA 23, 22382

MOSKALEV, Y. I., L. A. Buldakov, N. A. Koshurnikova, A. P. Nifatov and G. N. Reshetov

Combined effect of ${ }^{90} \mathrm{Sr},{ }^{144} \mathrm{Ce}$, and $239 \mathrm{Pu}$ on the rat organism (report 2)

In: Distribution and Biological Effect of Radioactive Isotopes

(Y. I. Moskalev ed., Atomizdat, Moscow) 356-365 (1966) translated

in AEC-tr-6944, 453-462 NSA 23, 22383

MOSKALEV, Y. I., and V. N. Streltsova

Late injuries from low-dose irradiation. (in French)

In: Progress in Radiology, Vol. II (L. Tuvavo, A. Ratti, and

C. Biagini, eds., Excerpta Medica Foundation, New York) 1364-1371

(1967) NSA 22, 38483

MOSKALEV, Y. I., G. A. Zalikin, I. K. Petrovich and E. I. Rudnitskaya

Radioresistance and radiosensitivity of animals to exposure to transuranium elements

Radiatsiya $i$ Organizm. Sbornik Material ov Konferentsii, 1 ,

Obinsk (1967) translated in UCRL-tr-1462, 3 p. NSA 26, $4 \overline{8} 282$

EP 5,152

MOSKALEV, Y. I. (ed.)

Radioactive Isotopes and the Body, Meditsina, Moscow, 458 p. (1969)

translated in AEC-tr-7195 NSA 25, 23946

MOSKALEV, Y. I., V. N. Streltsova and V. K. Lemberg Remote sequelae of radiation damage

In: Radioactive Isotopes and the Body (Y. I. Moskalev, ed., Meditsina, Moscow) (1969) translated in AEC-tr-7195, 439-458 NSA 25, 24225

MOSKALEV, Y. I., V. N. Streltsova and L. A. Buldakov

66-MOS

$66-M O S-3$

67-MOS

Late effects of radionuclide damage

In: Delayed Effects of Bone-Seeking Radionuclides (C. W. Mays, et a1., eds., Univ. of Utah Press, Salt Lake City) 489-509 (1969)

NSA 23, 38794

MOSKALEV, Y. I., L. A. Buldakov, A. M. Lyaginskaya, E. P.

$69-M O S-4$

Ovcharenko and T. M. Egorova

Experimental study of radionuclide transfer through the placenta and their biological action on the fetus

In: Radiation Biology of the Fetal and Juvenile Mammal (M. R. Sikov and D. D. Mahlum, eds., Doc. CONF-690501) 153-160 (1969) NSA 24, 23074

MOSKALEV, Y. I., E. I. Rudnitskaya, G. A. Zalikin and I. K. Petrovich 71-MOS Biological action of $237 \mathrm{~Np}$ nitrate (in Russian)

Gig. Sanit. 2, 42-47 (1971) NSA 25, 42253 
MOSKALEV, Y. I. (ed.)

Remote Aftereffects of Radiation Damage, Atomizdat, Moscow,

$71-\mathrm{MOS}-2$

528 p. (1971) translated in AEC-tr-7387 NSA 27, 9851, 9855, 9881

MOSKALEV, Y. I., G. A. Zalikin, I. K. Petrovich and V. P. Panova Characteristics of the biological effect of $241 \mathrm{Am}$

In: Remote Aftereffects of Radiation Damage (Y. I. Moskalev, ed., Atomizdat, Moscow) 395-401 (1971) translated in AEC-tr-7387, 434-440 PD 7, 356T

MOSKALEV, Y. I., and E. I. Rudnitskaya Some aspects of the biological effect of ${ }^{241} \mathrm{Am}$

In: Remote Aftereffects of Radiation Damage (Y. I. Moskalev, ed., Atomizdat, Moscow) 509-517 (1971) translated in AEC-tr-7387, 560-567 PD $\underline{7}, 355 T$

MOSKALEV, Y. I.

239Pu: Problems of its biological effect

Health Phys. 22, 723-729 (1972) NSA 26, 38743

MOSKALEV, Y. I., G. A. Zalikin, V. S. Stepanov and A. I. Semenov Comparative biological effectiveness of $152 \mathrm{Eu}$ and $244 \mathrm{Cm}$ Radiobiologiya 12,730-734 (1972) translated in AEC-tr-7415, 125130 NSA $27,27 \overline{7997}$

MOSKALEV, Y. I., and V. S. Kalistratova (eds.)

Biological Action of External and Internal Sources of Radiation, Meditsina, Moscow, 356 p. (1972) translated in AEC-tr-7457

NSA $\underline{28}, 6043 ; \underline{29}, 696$

MOSKALEV, Y. I., E. N. Rudnitskaya, G. A. Zalikin and I. K. Petrovich Distribution and biological effects of neptunium 237

In: Biological Effects of Radiation from External and Internal

Sources (Y. I. Moskalev and V. S. Kalistratova, eds., Meditsina,

Moscow) 220-229 (1972) translated in AEC-tr-7457, 330-341

NSA $\underline{30}, 9964$

MOSKALEV, Y. I., G. A. Zalikin and V. I. Trofimov

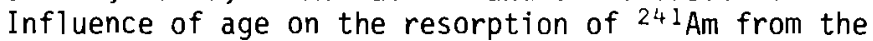
gastrointestinal tract of rats (Abstract)

Radiobiologiya 13, 155 (1973) translated in AEC-tr-7430, 215

PD 7, $981 T$

MOSKALEV, Y. I., and V. N. Streltsova Dependence of osteosarcomogenic activity of radionuclides on their physical properties and physiological state of the animal

In: Radionuclide Carcinogenesis (C. L. Sanders, et al., eds., Doc. CONF-720505) 307-311 (1973) NSA 28, 18560

MOSKALEV, Y. I.

Some important problems of biological action of transuranium elements

In: Health Physics Problems of Internal Contamination (E. Bujdoso, ed., Akademiai Kiado, Budapest) 187-195 (1973) NSA 2830280

EP $\underline{5}, 149$

MOSKALEV, Y. I., E.I. Rudnitskaya, G. A. Zalikin, I. K. Petrovich and T. I. Levdik

Metabolic behavior and biological effects of neptunium-237 (in Russian)

In: Proceedings of German-Soviet Working Meeting on the Question of Radiation Protection, Staatliche Zentrale fuer Strahlenschutz, Berlin, 12-28 (1973) NSA 30, 19028 
MOSKALEV, Y. I., G. A. Zalikin, R. M. Lyubimova-Gerasimova,

74-MOS

I. K. Petrovich and E. I. Rudnitskaya

Kinetics of exchange and biological action of americium-241 in dogs

Radiobiologiya 14, 261-265 (1974) translated in AEC-tr-7571, 131-

137 NSA $30,3 \overline{25} 66$

MOSKALEV, Y. I., G. A. Zalikin, V. N. Streltsova, A. I. Semenov,

I. K. Petrovich and E. S. Zhorova

Biological effects of californium-252

Radiobiologiya 14, 266-270 (1974) translated in AEC-tr-7571,

138-143 NSA $3 \overline{0}, 32567$

MOSKALEV, Y. I., E. I. Rudnitskaya, L. A. Buldakov, A. P. Nifatov

and L. G. Filippova

Remote after effects associated with damage by transuranium elements (ir Russian)

In: Proc. Third Int. Cong. Int. Radiat. Prot. Assn. (W. S. Snyder,

ed., Doc. CONF-730901-P1) Vol. 1, 167-171 (1974) NSA 30, 27224

MOSKALEV, Y. I., G. A. Zalikin and A. I. Semenov Kinetics of $244 \mathrm{~cm}$ accumulation in organs and tissues of rats in chronic introduction of the isotope into the body (in Russian)

Gig. Sanit. (6), 41-43 (1974) NSA 30, 24401

MOSKALEV, Y. I. See a1so: 61-BUIL, 61-BIJL-2, 69-BLIL, 69-BUL-2, 64-KRA, 61-LEB, 61-LEB-2, 62-LEB, 70-RUD, 72-RUD, 74-RUD, 73-SEA, 57-STV, 64-STV, 68-ZAL, 69-ZAL, 72-ZAL-2, 74-ZAL

74-MOS-2

$74-$ MOS -3

74-MOS-4

MOSS, 0. R. See: 71-KOT

MOSS, W. D., E. C. Hyatt and H. F. Schulte

Particle size studies on plutonium aerosols

61-MOW

Health Phys. 5, 212-218 (1961) EP S2, 294

MOSS, W. D., E. E. Campbe11, H. F. Schulte and G. L. Tietjen

Study of the variations found in plutonium urinary data

Health Phys. 17, 571-578 (1969) NSA 24, 564

MOSS, W. D. See also: 69-CAM, 72-CAM, 73-CAM, 67-ETI, 72-ETI, 58-FOR, 60-FOR

MOTT, W. E. See: 70-COD

MOTTA, E. SeE: 45-RUE

MOYER, R. A.

Savannah River experience with transplutonium elements

68-MOY

Health Phys. 15, 133-138 (1968) NSA 23, 16317

MUIR, J. R. See: $72-S N Y-2$

MUNTZ, J. A., and E. S. G. Barron

Combination of plutonium with plasma proteins

Doc. MDDC-1268 (CH-3757), 23 p. (1947) ADD 1, 1268

MUNTZ, J. A. See also: 45-BAR, 45-RUE

MURAMATSU, M. SEe: 68-TAS

MURRAY, J.L. See: 68-WOD

MURRAY, R. G.

Gross and histopathology of animals treated with plutonium

In: Report of Conference on Plutonium (J. J. Nickson, ed.,

Doc. CN-3167) 16-18 (1945) EP S3, 291 
MURRAY, R. G.

48-MUR

The spleen

In: Histopathology of Irradiation from External and Internal Sources

(W. Bloom, ed., McGraw Hill, New York) 243-347 (1948)

MURRAY, R. G.

48-MUR-2

The thymus

In: Histopathology of Irradiation from External and Internal Sources

(W. Bloom, ed., McGraw Hi11, New York) 446-501 (1948)

MURTHY, M. S. S. See: 74-MAD

MUSEN, L. G. See: 72-EDL

MUSHKACHEVA, G. S., and I. A. Tseveleva

Effect of inhalation affection of rabbits by plutonium on chemical composition of blood (in Ukranian)

Ukr. Biokhim. Zh. 41, 306-310 (1969) NSA 23, 48208

MUSHKACHEVA, G. S.

Activity in nucleases in rabbit lungs afier inhalation of plutonium (in Russian)

Vop. Med. Khim. 17, 301-305 (1972) NSA 26, 43381

MUSHKACHEVA, G. S. See also: 72-BUL, 72-KOS, 73-KOS, 70-KRE, 68-TSE, 71-TSE

MUSSALO, H., T. Jaakkola and J. K. Miettinen

Plutonium in reindeer liver in Finnish Lapland during 1964-1973. Preliminary results

In: Radioactive Foodchains in the Subarctic Environment ( $\mathrm{J} . \mathrm{K}$.

Miettinen, ed., Helsinki Univ.) Paper 63 (1974) NSA 30, 15447

MYATT, J.

Radioisotope-fuelled batteries for heart pacemakers

69-MUS

Bio-med. Eng. 6⑸, 192-196 (1971) NSA 25, 46594

MYERS, D. S.

A plea for consistent lung burden criteria for insoluble alpha emitting isotopes

Health Phys. 22, 905-909 (1972)

MYERS, G. H. See: 73-PAV 
NABORS, C. J., Jr., W. Stevens and R. E. Maxwe 11

Comparative effects of ${ }^{239} \mathrm{Pu}$ and ${ }^{241} \mathrm{Am}$ on biochemical parameters:

Effect of dose and radionuclide burden time

In: Radiobiology of Plutonium (B. J. Stover and W. S. S. Jee, eds.,

J. W. Press, Salt Lake City) 87-103 (1972) NSA 26, 41256

NABORS, C. J., Jr., and J. S. Hinckley

Cortisol metabolism in skin of beagles bearing $241 \mathrm{Am}$

$75-N A B$

Radiat. Res. 61, 513-518 (1975) NSA 31, 29979

NABORS, C. J., Jr. See also: 69-BED, 67-STW

NAKAURA, M. See: 71-SAK-2

NATIONAL Academy of Sciences - National Research Council -

Subcommittee on Inhalation Hazards of the Committee on Pathologic Effects of Atomic Radiation

Effects of Inhaled Radioactive Particles. Fublication 848.

NAS-NRC, Washington, D.C., 78 p. (1961) NSA 15, 27399

NATIONAL Academy of Sciences - National Research Council -

Advisory Committee on the Biological Effects of Ionizing

Radiations

The Effects on Populations of Exposure to Low Levels of

Ionizing Radiation, NAS-NRC, Washington, 217 p. (1972)

NSA 28, 2908

NEBEKER, N. See: 72-CHR

NECHAEV, K. K. See: 74-ZAP

NECHEV, K.

Early phases of plutonium-239 metabolism with the radioisotope

72-NEC

introduced at various sites of the vascular system (in Bulgarian)

Rentgeno1. Radiol. 11, 92-96 (1972) NSA 31, 14434

NECHEV, K.

Metabolic processes in the bone tissue of animals following plutonium-239 administration at different sites of the vascular system (in Bulgarian)

Rentgenol. Radiol. 12, 103-107 (1973) PD 8, 2871

NECHEV, $K$.

Physicochemical state of plutonium-239 in rat blood plasma and tissue (in Bulgarian)

Rentgeno1. Radiol. 12, 107-112 (1973) NSA 31, 14435

NECHEV, K.

Early phases of $239 \mathrm{pu}$ metabolism after peroral administration in the animal organism (in Bulgarian)

Rentgenol. Radiol. 12, 171-174 (1973) NSA 30, 27276

NEEF, W. I., and J. E. Ballou

Ultrasonic methods of decontaminating rat skin contaminated with

$91 \mathrm{Y}$ and $239 \mathrm{pu}$

Doc. HW-51938, 4 p. (1957)

NELSON, A. See: 62-ULB

NELSON, I . C.

Theoretical excretion of plutonium in urine based on the new

ICRP lung model

In: Diagnosis and Treatment of Deposited Radionuclides (H. A. Kornberg

and W. D. Norwood, eds., Excerpta Medica Foundation, Amsterdam) 266-

278 (1968) NSA $2 \underline{3}, 24640$ 
NELSON, I. C.

Urinary excretion of plutonium deposited in the lung

69-NEL

Health Phys. 17, 514-516 (1969) NSA 23, 45632

NELSON, I. C.

Simplified method for evaluating the Healy plutonium excretion

72-NEL equation

Health Phys. 22, 191-193 (1972)

NELSON, I. C., K. R. Heid, P. A. Fuqua and T. D. Mahony

Plutonium in autopsy tissue samples

Health Phys. 22, 925-930 (1972) NSA 26, 15524

NELSON, I. C. See al so: 67-ANB, 74-BAI-4, 68-NEW

NELSON, N. S. See: 71-STA

NENOT, J. C., R. Masse and J. Lafuma

Metabolism of plutonium (in French)

Radioprotection 2 , 297-312 (1967) PD $\underline{3}, 615$

NENOT, J. C., M. Morin and J. Lafuma

Experimental study of $242 \mathrm{~cm}$ contamination and treatment

72-NEL-2

Health Phys. 18, 613-622 (1970) translated in AEC-tr-7178

NSA 25, 6619

NENOT, J. C.

Study of the effect of irradiation on lung clearance (in French)

71-NEO

In: Inhaled Particles III (W. H. Walton, ed., Unwin Bros. Ltd.,

01d Woking, England) 239-246 (1971) NSA 26, 12508

NENOT, J. C., M. Morin and J. Lafuma

Metabolic and therapeutic study of respiratory contamination by certain actinides ( $\mathrm{Pu}, \mathrm{Am}$, and $\mathrm{Cm}$ ) in solution

Health Phys. 20, 167-177 (1971) translated in ORNL-tr-2491

NSA 25,46676

NENOT, J. C., M. Morin and J. Lafuma

Experimental contaminations by solutions of americium and their treatment

Health Phys. 20, 383-391 (1971) translated in LF-tr-61 NSA 25, 44800

NENOT, J. C., M. Morin and J. Lafuma

Experimental study of the decontamination of the skeleton after inhalation of americium nitrate

Health Phys. 21, 395-400 (1971) translated in UCRL-Trans-1477

NSA 25, 49092

NENOT, J. C., M. Morin, P. Massey and J. Lafuma

Metabolic study of the binding of plutonium to serum proteins

(in French)

Doc. CEA-R-4263, 11 p. (1971) NSA 26, 25906

NENOT, J. C., R. Masse, M. Morin and J. Lafuma

Experimental comparative study of the behaviour of $237 \mathrm{~Np},{ }^{238} \mathrm{Pu}$, ${ }^{239} \mathrm{Pu}, 241 \mathrm{Am}$, and ${ }^{242} \mathrm{Cm}$ in bone

Health Phys. 22, 657-665 (1972) NSA 26, 38778

NENOT, J. C., M. Morin, W. Skupinski and J. Lafuma

Experimental removal of $144 \mathrm{Ce}, 241 \mathrm{Am}, 242 \mathrm{Cm}$ and $238 \mathrm{Pu}$ from the rat skeleton

Health Phys. $\underline{23}, 635-640$ (1972) NSA 26, 56571

71-NEO-4

$71-N E 0-5$

72-NEO

72-NEO-2 
NENOT, J. C. See also: 72-DUC, 74-DUC, 68-LAF, 71-LAF, 72-LAF, 74-LAF-2, 71-MOR, 72-MOR, 73-MOR, 73-MOR-2, 73-MOR-3, 73-MOR-4, 74-MOR

NEVADA Applied Ecology Group

The dynamics of plutonium in desert environments (Progress Report,

P. B. Dunaway and M. G. White, eds.)

Doc. NV0-142, 369 p. (1974) NSA 30, 29439

NEVISSI, A., and W. R. Schel1

Distribution of plutonium and americium in Bikini Atoll lagoon

Health Phys. 28, 539-547 (1975) NSA 32, 11545

NEVSTRUYEVA, M. A., V. A. Kolotvin, R. Y. Livshits and V. M. Shubik

Effect of incorporated radionuclides on immunity (in Russian)

In: Proc. Third Int. Cong. Int. Radiat. Prot. Assn. (W. S. Snyder,

ed., Doc. CONF-730901-P1) Vol. 1, 141-146 (1974) NSA 30, 27222

NEWCOMBE, C. L. See: 68-TER

NEWTON, C. E., Jr., H. V. Larson, K. R. Heid, I. C. Nelson,

P. A. Fuqua, W. D. Norwood, S. Marks and T. D. Mahony

Tissue analysis for plutonium at autopsy

In: Diagnosis and Treatment of Deposited Radionuclides ( $H$. A. Kornberg

and W. D. Norwood, eds., Excerpta Medica Foundation, Amsterdam)

$460-468$ (1968) NSA 23, 24649

NEWTON, C. E., Jr. See also: 68-LAR, 72-NOJ, 73-NOR, 74-NOR, 75-NOR

NEWTON, D., J. Rundo and B. T. Taylor Progress in instrumentation and calibration techniques for the assessment of lung burdens of $239 \mathrm{Pu}$

In: Radiation Protection Problems Relating to Transuranium Elements

(Doc. EUR-4612) 469-482 (1971) NSA 25, 37801

NEWTON, D., F. A. Fry, B. T. Taylor and M. C. Eagle Factors affecting the assessment of ${ }^{239} \mathrm{Pu}$ in vivo by external counting methods

In: Assessment of Radioactive Contamination in Man (International

Atomic Energy Agency, Vienna) 83-96 (1972) NSA 26, 56521

NEWTON, D., and M. C. Eagle

Measurement of ${ }^{252} \mathrm{Cf}$ in vivo

Health Phys. 23, 817-825 (1972) PD 7, 46T

NEWTON, D. See also: 68-RLIN

NEWTON, G. J. See: 75-RAB

NG, Y. C., C. A. Burton, S. E. Thompson, R. K. Tandy,

$68-N G Y$.

H. K. Kretner and M. W. Pratt

Prediction of the maximum dosage to man from the fallout of nuclear devices. IV. Handbook for estimating the maximum internal dose from radionuclides released to the biosphere

Doc. UCRL-50163 (Part IV), 171 p. (1968) EP S1, 127 NSA 23,

8004

NIAS, A. H. W., A. Howard, D. Greene and D. Major Response of Chinese hamster (ovary) cells to protracted irradiation from ${ }^{252} \mathrm{Cf}$ and ${ }^{60} \mathrm{Co}$

Brit. J. Radiol. 46, 991-995 (1973) NSA 29, 26973

NICKSON, J. J. (ed.)

45-NIC Report of conference on plutonium Doc. CN-3167 (1945) NSA $\underline{30}, 21069$ EP S3, 286 
NICKSON, J. J.

$45-N I C-2$

Therapeutic experiments and suggestions

In: Report of Conference on Plutonium (J. J. Nickson, ed.,

Doc. CN-3167) 57-62 (1945) EP S3, 295

NICKSON, J. J. See a1so: 45-HEM, 51-RUE

NIFATOV, A. P.

The dynamics of the morphological changes in the livers of rabbits under the influence of plutonium-239

In: Biological Effects of Radiation and Problems of Radioactive

Isotope Distribution (A. V. Lebedinskij and Y. I. Moskalev, eds.,

Atomizdat, Moscow) 145-154 (1961) translated in AEC-tr-5265, 144-152

NSA $\underline{16}, 9915$ EP S2, 300

NIFATOV, A. P.

The long-term effects of intraperitoneal introduction of plutonium

$61-N I F-2$ acetate

In: Biological Effects of Radiation and Problems of Radioactive Isotope Distribution (A. V. Lebedinskii and Y. I. Moskalev, eds., Atomizdat, Moscow) 174-181 (1961) translated in AEC-tr-5265,

172-179 NSA $\underline{16}, 9918$ EP $\underline{\text { S2}}, 298$

NIFATOV, A. P. Morphological changes in rabbit and dog liver induced by $239 \mathrm{pu}$

In: Plutonium-239: Its Distribution, Biological Effect and Accelerated Elimination (A. V. Lebedinski $i$ and Y. I. Moskalev, eds., Medgiz, Moscow) 129-141 (1962) translated in FTD-TT-63-559, 194-214 NSA 17, 30252

NIFATOV, A. P., and L. A. Buldakov

Microdistribution of $239 \mathrm{Pu}$ in the bone tissue of rats during chronic peroral administration of the isotope

In: Remote Aftereffects of Radiation Damage (Y. I. Moskalev, ed.,

Atomizdat, Moscow) 365-372 (1971) translated in AEC-tr-7387,

399-405 PD $\underline{7}, 2075$

NIFATOV, A. P., L. A. Buldakov and L. G. Filippova Comparative toxicity of ${ }^{241} \mathrm{Am}$ nitrate and citrate

In: Remote Aftereffects of Radiation Damage (Y. I. Moskalev, ed., Atomizdat, Moscow) 387-395 (1971) translated in AEC-tr-

$7387,425-433$ PD $\underline{7}, 357 \mathrm{~T}$ EP $\underline{5}, 160$

NIFATOV, A. P., L. A. Buldakov and V. I . Matveev

Some late effects after a single inhalation of $239 \mathrm{Pu}$ and ${ }^{241} \mathrm{Am}$ in dogs

Health Phys. 22, 875 (1972) NSA 26, 38751

NIFATOV, A. P., L. A. Buldakov and L. G. Filippova

61-NIF

$62-N I F$

Blastomogenic effect of americium 241

In: Biological Effects of Radiation from External and Internal

Sources (Y. I. Moskalev and V. S. Kalistratova, eds., Meditsina, Moscow) 340-345 (1972) translated in AEC-tr-7457, 498-504

NSA 30,9977

NIFATOV, A. P. See also: 69-BUK. 67-BUL, 68-BUL-2, 69-BUL, 71-BUL-3, 71-BUL-4, 72-BUL, 72-BUL-4, 72-BUL-5, 64-ERO, 69-ERO, 71-ERO, 74-FIL, 74-FIL-2, 68-KOS, 61-LEM, 62-LEM, 66-LEM, 74-LEV-2, 72-LYU-3, 65-MOS, 66-MOS-2, 66-MOS-3, 74-MOS-3, 72-PUZ

NILSSON, A. See: 70-HAL, 70-HAL-2 
NISHITA, H., E. M. Romney and K. H. Larson

65-NIS

Uptake of radioactive fission products by plants

In: Radioactive Fallout, Soils, Plants, Foods, Man (E. B. Fowler, ed., Elsevier, New York) 55-81 (1965) EP S1, 874

NISHITA, H. See also: 45-0LA

NODA, Y. See: 71-JOS, 71-MAO-3, 72-MAO

NOL IBE, D.

72-NOL

In vitro migration measurements of alveolar histiocytes: Comparative effect of antiserums and plutonium oxide poisoning

Compt. Rend. Ser. D. 274, 77-80 (1972) translated in LF-tr-73

NSA 26,$33786 ; 27,28 \overline{43}$

NOL IBE, D.

Morphologic study of microcinematography and scanning electron microscopy of the phagocytosis of plutonium oxide by the alveolar histiocyte (in French)

C. R. Acad. Sci. Paris, Ser. D, 276, 65-68 (1973) NSA 28, 2996

NOL IBE, D.

Elimination by pulmonary lavage, in vivo, of inhaled plutonium oxide particles. Description of techniques used

C. R. Acad. Sci. Paris, Ser. D, 276, 225-228 (1973) translated in BNWL-tr-96 NSA 28, 24871

NOL IBE, D.

Elimination by pulmonary lavage, in vivo, of inhaled plutonium oxide particles. Treatment times (in French)

C. R. Acad. Sci. Paris, Ser. D, 276, 681-684 (1973) NSA 28, 6084

NOLIBE, D. See also: 70-KUN, 70-KUN-2, 70-KUN-3, 71-KUN, 74-LAF-2, 70-LUT, 72-MET, 74-MET

NORCROSS, J. A., and C. E. Newton, Jr.

U. S. Transuranium Registry: A progress report

72-NOJ

Health Phys. 22, 887-890 (1972) NSA 26, 38754

NORCROSS, J. A. See also: 73-NOR

NORMAN, J., C. Pegg, G. Sandberg, R. Lee and F. Huffman

Effects of intracorporeal heat and radiation on dogs

Artificial Heart Program Conference, Washington D.C. (R. J. Hegyeli, ed., (DoC. CONF-690655) 901-911 (1969) NSA 25, 26931

NORMAN, J. C., F. N. Huffman, F. A. Molokhia, P. J. Asimacopoulos and $S$. Warren

Implantable nuclear power sources for artificial hearts: Progress report, two years after implantation in the dog

Bu11. Soc. Int. Chir. 32, 62-74 (1973) NSA 29, 15803

NORMAN, J. See also: 69-SAG, 70-SAG

NORW00D, W. D., P. A. Fuqua and B. C. Scudder

Treatment of acute plutonium poisoning

Indust. Med. Surg. 25, 135-139 (1956) BA 30, 28313 EP 5, 386

NORWOOD, W. D.

Treatment of plutonium poisoning with zirconium citrate and with CaEDTA

In: Therapy of Radioelement Poisoning (M. W. Rosentha1, ed., Doc. ANL-5548) 36-44 (1956) EP S2, 201 
NORWOOD, W. D., P. A. Fuqua, R. H. Wilson and J. W. Healy

Treatment of plutonium inhalation - Case studies

Proc. Int. Conf. Peaceful Uses At. Energy 23, 434-438 (1958)

Also: In: Progress in Nuclear Energy, VII, 2, 105-113 (1959)

NSA 12,14551 EP 5,385

NORWOOD, W. D.

The determination of injury from the internally deposited

radioisotope plutonium

J. 0ccup. Med. 1, 269-276 (1959)

NORWOOD, W. D.

DTPA-effectiveness in removing internally deposited plutonium from

$60-N O R$

humans

J. Occup. Med. 2, 371-376 (1960)

NORWOOD, W. D.

Radioactive material in the body. Detection and treatment

Arch. Environ. Health $\underline{5}(2), 167-172$ (1962) NSA $\underline{16}, 31451$

NORWOOD, W. D.

Therapeutic removal of plutonium in humans

$59-N O R$

Health Phys. $\underline{8}, 747-750$ (1962) NSA 17, 10336

NORWOOD, W. D.

Long-term administration of DTPA for plutonium elimination -

A followup study in one patient

J. 0ccup. Med. 4, 130-132 (1962) NSA 18, 31109

NORWOOD, W. D.

Early diagnosis and treatment of individuals who have excessive depositions of radioisotopes

J. Occup. Med. 4, 373-382 (1962) NSA 17, 27208

NORWOOD, W. D.

Medical therapy for internally deposited radioisotopes

Am. Ind. Hyg. Assoc. J. 24, 492-496 (1963) NSA 18, 1461

NORWOOD, W. D.

Removal of plutonium and other transuranic elements from man

62-NOR

$62-N O R-2$

$62-N O R-3$

$62-N O R-4$

In: Diagnosis and Treatment of Radioactive Poisoning (International

Atomic Energy Agency, Vienna) 307-318 (1963) NSA 17, 2797

NORWO0D, W. D., and P. A. Fuqua

Medical care for accidental deposition of plutonium (239Pu) within the body

In: Handling of Radiation Accidents (International Atomic Energy

Agency, Vienna) 147-162 (1969) NSA 24, 7941

NORWOOD, W. D.

Plutonium (239Pu) Toxicity diagnosis and therapy

$72-N O R$

J. Occup. Med. 14, 37-44 (1972) PD 7, 1221

NORWOOD, W. D.

U. S. Transuranium Registry: Progress and expectations

In: Radiobiology of Plutonium (B. J. Stover and W. S. S. Jee,

eds., J. W. Press, Salt Lake City) 531-537 (1972) NSA 26, 41271

NORWOOD, W. D., J. A. Norcross, C. E. Newton, Jr., D. B. Hylton

63-NOR

$63-N O R-2$

and $C$. Lagerquist

Preliminary autopsy findings in U. S. Transuranium Registry Cases

In: Radionuclide Carcinogenesis (C. L. Sanders, et al., eds., Doc.

CONF-720505) 465-474 (1973) NSA 28, 18541

$69-N O R$

73-NOR 
NORWOOD, W. D., and C. E. Newton, Jr.

74-NOR

United States Transuranium Registry Summary Report to June 30,

1974 to USAEC Division of Biomedical and Environmental Research DoC. HEHF-22 (1974)

NOIRWOOD, W. D., and C. E. Newton Jr.

U. S. Transuranium Registry study of thirty autopsies

75-NOR

Health Phys. 28, 669-675 (1975) NSA 32, 17556

NORW00D, W. D. See also: 54-FOR, 68-NEW

NOSHKIN, V. E., V. T. Bowen, K. M. Wong and J. C. Burke

$71-\mathrm{NOS}$

Plutonium in North Atlantic Ocean organisms; ecological relationships

In: Radionuclides in Ecosystems, Vol. 2 (D. J. Nelson, ed., Doc.

CONF-710501-P2) 681-688 (1971) NSA 26, 45541 EP S1, 878

NOSHKIN, V. E., and V. T. Bowen

72-NOS

Concentrations and distributions of long-lived fallout radionuclides

in open ocean sediments

Doc. C00-3563-3, 22 p. (19\%2) NSA 26, 45531 EP S1, 879

NOSHKIN, V. E.

Ecological aspects of plutonium dissemination in aquatic environments Health Phys. 22, 537-549 (1972) NSA 26, 4715

NOSHKIN, V. E., Jr., and C. Gatrousis

Fallout $240 \mathrm{Pu}$ and ${ }^{239} \mathrm{Pu}$ in Atlantic marine samples

Earth Planet. Sci. Lett. 22, 111-117(1974) NSA 30, 3168

NOSHKIN, V. E., K. M. Wong, R. J. Eagle and C. Gatrousis

Transuranics at Pacific atolls. I. Concentrations in the waters at Enewetak and Bikini

Doc. UCRL-51612, 30 p. (1974) NSA 30, 3383

NOSHKIN, V. E. See also: 71-BOW

NOVOSELOVA, G. P. See: 71-GNE-2

NUTTINCK, D. See: 71-DUL 
OAKLEY, W. D., and R. C. Thompson

Further studies on percutaneous absorption and decontamination

$56-0 A K$ of piutonium in rats

Doc. HW-41500, 106-113 (1956) EP S2, 206

OAKLEY, W. D. See a 1so: 57-BAL, 55-KAT-2, 53-WEK, 53-WEK-2, 54-WEK, 55-WEK, 55-WK-2, 56-WEK

ODLAND, L. T., R. L. Farr, K. E. Blackburn and A. J. Clay

$68-0 \mathrm{DL}$ Industrial medical experience associated with the Palomares nuclear incident

J. Occup. Med. $\underline{10}, 356-362$ (1968) NSA 22, 43318

ODLAND, L. T., R. G. Thomas, J. C. Taschner, H. R. Kaufman and R. E. Benson

Bioassay experiences in support of field operations associated with widespread disperson of plutonium

In: Diagnosis and Treatment of Deposited Radionuclides (H. A. Kornberg and W. D. Norwood, eds., Excerpta Medica Foundation, Amsterdam)

$256-265$ (1968) NSA 23, 24639

OHLENSCHLAEGER, L. Report of a perforating and incised wound of the left forefinger contaminated with $241 \mathrm{Am}$ (in German)

Strahlentherapie 142, 73-79 (1971) NSA 26, 9572

OHLENSCHLAEGER, L.

Surgical treatment of alpha-contaminated injuries (in German)

In: Radiation Protection Problems Relating to Transuranium Elements

(Doc. EUR-4612) 563-572 (1971) NSA 25, 37782

OHLENSCHLAEGER, L., and H. Schieferdecker

Report about a plutonium-239 contaminated lacerated and incised wound (in German)

Strahlentherapie 146, 675-684 (1973) NSA 30, 21420

OHNO, S. See: 71-SUZ-2

OKABAYASHI, $\mathrm{H}$. and $\mathrm{H}$. Watanabe

Concentration of plutonium in Japanese human bone

J. Radiat. Res. 14, 363-368 (1973) NSA 31, 33550

OKABAYASHI, H. See also: 71-SUZ-2

OKSENTYUK, G. S. SeE: 71-KAV

OLAFSON, J. H., N. Nishita and K. H. Larson

Distribution of plutonium in the soils of central and northeastern

New Mexico as a result of the atomic bomb test of July 16, 1945

Doc. UCLA 406, 24 p. (1945) NSA 11, 13247 EP 28

OLAFSON, J. H., and K. H. Larson

Plutonium, its biology and environmental persistence

In: Radioecology (V. Schultz and A. W. Klement, Jr., eds., Reinhold, New York) 633-639 (1963) NSA 16, 9812

OLIVER, G. D., Jr. See: 73-BEY, 70-BUC, 73-BUC, 73-CAJ, 71-WIT

OLSON, J. S., S. I. Auerbach, D. G. Jacobs and T. Tamura

Distribution of radioactive isotopes in plants, insects and soils

Nuc1. Safety 1, 2-9 (1960)

OLSON, R. J. See: 74-PAR

ORESHINA, A. F. See: 70-SMO, 68-TAR 
OSANOV, D. P., E. B. Ershov, O. V. Klickov and V. A. Rackova

71-OSA

Kinetics of dose distribution in structural layers of skin contaminated with radioactive materials

Health Phys. 20, 559-599 (1971) NSA 25, 46829

OSANOV, D. P., M. Y. Tissen and V. V. Filatov

Determination of the content of plutonium in the human organism

$71-0 S A-2$

by the rate of its elimination (in Russian)

Med. Radiol. 16(4), 44-51 (1971) NSA 25, 32334

OSANOV, D. P., E. B.Ershov, 0. Klikov and V. A. Rackova Kinetics of dose distribution in skin contaminated with radioactive substances (in Russian)

Med. Radiol. 16(5), 44-50 (1971) NSA 25, 42257

OSANOV, D. P., V. V. Filatov and M. Y. Tissen Determination of $239 \mathrm{Pu}$ in a living human organism from the rate of its elimination

In: Health Physics Problems of Internal Contamination (E. Bujdoso, ed., Akademiai Kiado, Budapest) 491-496 (1973) NSA 28, 30307

OSANOV, D. P. See also: 70-ERS, 74-ERS

OSBORNE, R. V.

Plutonium-239 and other nuclides in ground-level air and human lungs during Spring 1962

Nature 199, 143-146 (1963) NSA 17, 30770

0'TOOLE, J. J. See: 75-FEL

OVCHARENKO, E. P.

Transfer of transuranium elements to the offspring of rats with milk

Radiobiologiya 11, 566-569 (1971) translated in Doc. AEC-tr-7304, $110-114$ NSA $2 \overline{6}, 36458$

OVCHARENKO, E. P.

Peculiarities of the postnatal development of offspring of male rats treated with $241 \mathrm{Am}$

Radiobiologiya 11, 570-574 (1971) translated in Doc. AEC-tr-7304,

$115-120$ NSA $2 \overline{6}, 36452$

OVCHARENKO, E. P. Effect of $241 \mathrm{Am}$ on the functional state of sex glands in female rats

In: Remote Aftereffects of Radiation Damage (Y. I. Moskalev, ed., Atomizdat, Moscow) 421-430 (1971) translated in AEC-tr-7387, 463-

472 PD 7, 358T

OVCHARENKO, E. P.

Characteristics of postnatal development of offspring of female rats exposed to ${ }^{241} \mathrm{Am}$

In: Remote Aftereffects of Radiaton Damage (Y. I. Moskalev, ed.,

Atomizdat, Moscow) 430-438 (1971) translated in AEC-tr-7387,

473-482 PD 7, 359T

OVCHARENKO, E. P.

Experimental evaluation of the effects of transuranic elements on reproductive ability

Health Phys. 22, 641 (1972) NSA 26, 38740

OVCHARENKO, E. P.

Quantitative estimation of $241 \mathrm{Am}$ effect on the morphological

structure of rat ovary (Abstract) (in Russian)

Radiobiologiya 12, 628 (1972) PD 프, 360T 
OVCHARENKO, E. P.

$72-0 V C-3$

Effect of $241 \mathrm{Am}$ on the spermatogenesis of rats (Abstract)

(in Russian)

Radiobiologiya 12, 629 (1972) PD ㄱ, 361T

OVCHARENKO, E. P, and A. M. Lyaginskaya

72-OVC-4

Histopathology of rat testicles damaged by americium 241

In: Biological Effects of Radiation from External and Internal Sources,

(Y. I. Moskalev and V. S. Kalistratova, eds., Meditsina, Moscow)

334-340 (1972) translated in AEC-tr-7457, 491-497 NSA 30, 9976

OVCHARENKO, E. P.

Investigation of the functional state of the ovaries of rats after

74-OVC introduction of plutonium-239 (Abstract)

Radiobiologiya 14, 466 (1974) translated in AEC-tr-7596, 197

OVCHARENKO, E. P. Influence of transuranic elements on the sex glands of male rats (Abstract)

Radiobiologiya 14, 467 (1974) translated in AEC-tr-7596, 199

OVCHARENKO, E. P. See also: 71-BUL-2, 71-LYA, 69-MOS-4

OVERSTREET, R., L. Jacobson, H. Fisher and K. Scott Progress Report on Metabolism of Fission Products for Period Ending October 15, 1943

Doc. MDDC-1011 (CH-1049), 61 p. (no date) ADD 1, 1011

OVERSTREET, R. See also: 48-JAL

OWEN, J. B.

Control of personnel exposures to external radiations in a plutonium chemical plant

In: Health Physics Operational Monitoring, Vol. 2 (C. A. Willis, ed., Gordon and Breach, New York) 1215-1222 (1972) NSA 29, 29780 
PAGANINI FIORATTI, M., and S. Ricci Piermatte $i$

73-PAF

Evaluation of activity in lung and $1 \mathrm{ymph}$ nodes following inhalation of radioactive insoluble aerosols

In: Health Physics Problems of Internal Contamination (E. Bujdoso,

ed., Akademiai Kiado, Budapest) 65-76 (1973) NSA 28, 30348

PAGLIA, D. E.

Hematopathologic surveys of kangaroo rats (Dipodomys microps)

populating plutonium contaminated regions of the Nevada Test Site

Health Phys. 15, 493-498 (1968) NSA 23, 7975

PAINE, D., J. E. Johnson and R. L. Watters

Plutonium movement in aquatic systems: A review

In: Proceedings of the Rocky Flats Symposium on Safety in Plutonium

Handling Facilities (Doc. CONF-710401) 407-410 (1971) NSA 25,

55150

PAINTER, E., E. Russell, C. L. Prosser, M. N. Swift, W. Kisieleski and G. Sacher

Clinical physiology of dogs injected with plutonium

Doc. AECD-2042 (CH-3858) 129 p. (1946) NSA 1,42

PAINTER, E. See also: 45-COK-2, 45-RLIE

PALMER, H. E. See: 62-ROE

PAL0TAY, J. L. See: 66-BAL, 67-BAL, 64-CLA-2, 66-CLA, 65-MAH, 68-SMV, 68-WOD

PANOVA, V. P. See: 71-MOS-3

PARK, H. Z., S. W. Whitson and W. S. S. Jee

72-PAZ

Vascular theory of radiation injury to bone

In: Radiobiology of Plutonium (B. J. Stover and W. S. S. Jee, eds.,

J. W. Press, Salt Lake City) 305-322 (1972) NSA 26, 41261

PARK, J. F., D. H. Willard, S. Marks, J. E. West, G. S. Vogt and

W. J. Bair

Acute and chronic toxicity of inhaled plutonium in dogs

Health Phys. 8 , 651-657 (1962) NSA 17, 10322

PARK, J. F., W. J. Clarke and W. J. Bair

Chronic effects of inhaled plutonium in dogs

64-PAR

Health Phys. 10, 1211-1217 (1964) NSA 19,3863

PARK, J. F., W. J. Clarke and W. J. Bair

Plutonium particle-induced neoplasia of the canine lung. I.

Clinical and gross pathology

In: Lung Tumors in Animals (L. Severi, ed., University of Perugia,

Perugia, Italy) 331-344 (1966) NSA 19, 38359

PARK, J. F., E. B. Howard and W. J. Bair

Acute toxicity of inhaled ${ }^{238} \mathrm{PuO}_{2}$ in beagle dogs

AFWL-TR-69-75, 66 p. (1969)

PARK, J. F., E. B. Howard, B. 0. Stuart, A. P. Wehner and J. V.

Dilley

Cocarcinogenic studies in pulmonary carcinogenesis

In: Morphology of Experimental Respiratory Carcinogenesis (P.

Nettesheim, et a1., eds., Doc. CONF-700501) 417-436 (1971)

NSA 25, 32530

PARK, J. F. , W. J. Bair and R. H. Busch

Progress in beagle dog studies with transuranium elements at Battelle-Northwest

Health Phys. 22, 803-810 (1972) NSA 26, 38747 
PARK, J. F., D. L. Catt, D. K. Craig, R. J. 01 son and V. H. Smith Solubility changes of $238 \mathrm{Pu}$ oxide in water suspension and effect on biological behavior after inhalation by beagle dogs

In: Proc. Third Int. Cong. Int. Radiat. Prot. Assn. (W. S. Snyder, ed., Doc. CONF-730901-P1) Vol. 1, 719-724 (1974)

PARK, J. F. See also: 63-BAI-2, 64-BAI, 66-BAI, 68-BAI, 72-BAI, 73-BAI, 72-BAL-2, 64-CLA-2, 65-CLA, 66-CLA, 72-CRD, 71-SAN-2, 68-STU, 67-SWI, 72-SWI-2, 72-TH0-2, 63-TOM

PARKER, H. G., A. de G. Low-Beer and E. L. Isaac

Comparison of retention and organ distribution of ${ }^{241} \mathrm{Am}$ and

${ }^{252} \mathrm{Cf}$ in mice: The effect of in vivo DTPA chelation

Health Phys. 8, 679-684 (1962) NSA 16, 9765

PARKER, H. G., S. R. Wright, A. de G. Low-Beer and D. J. Yaeger

Metabolism of 253 Es in mice

Health Phys. 22, 647-651 (1972) NSA 26-38776

PARKER, H. G., and S. R. Wright

Whole-body counting of $241 \mathrm{Am}$ and ${ }^{252} \mathrm{Cf}$ with the Anger camera

Health Phys. 22, 891-897 (1972) NSA 26, 38479

PARKER, H. M.

Status of Product Monitoring by Health Physics Section

62-PAH

oc. $\mathrm{CN}-1892,9$ p. (1944) NSA 30, 21087

PARKER, H. M.

Radiation exposure experience in a major atomic energy facility

Proc. Int. Conf. Peaceful Uses At. Energy 13, 266-269 (1956)

PARKER, H. M.

Biological implications of the transuranic elements for man

Health Phys. 22, 953-954 (1972) NSA 22, 38732

PARKER, H. M.

Plutonium. Industrial hygiene, health physics and related aspects

In: Uranium-Plutonium-Transplutonic Elements ( $H$. C. Hodge, J. N.

Stannard and J. B. Hursh, eds., Springer-Verlag, New York) 613-667

(1973) PD 8, 1024

PARKER, H. M. See also: 55-KAT, 56-TH0-2

PARKHOMENKO, G. M. See: 72-KHO

PARSONNET, V., T. F. Hursen and G. H. Myers Development of radioisotope power sources for pacemakers in the United States

In: Cardiac Pacing (H. J. Thalen, ed., Van Gorcum, Assen) 192-197

(1973) PD 8, 1817

PARSONT, M. A., W. L. Holley and W. D. Burnett

Effect of particle size on organ distribution of radioactive material deposited in the lungs

Health Phys. 22, 143-148 (1972)

PASQUIER, C. See: 72-DUC, 74-DUC

PASTERNACK, B. S. See: 75-HAI

PATIN, S. A., V. L. Pechkurenkov and I. A. Shekhanova fossilis spawn

Radiobiologiya 11,742-746 (1971) translated in AEC-tr-7306,

153-159 NSA $2 \overline{6}, 38759$

PATTI, F. See: 64-JEA 
PAYNE, J. G. See: 72-MIL

PEABODY, C. 0. See: 64-SPE

PECHKURENKOV, V. L. See: 71-PAT

PEGG, C. A. S. See: 69-NOM, 69-SAG

PENDLETON, R. C., C. W. Mays, R. D. Lloyd and N. V. Hancock

64-PEN

Fall-out ${ }^{239} \mathrm{Pu}$ and ${ }^{95} \mathrm{Zr}$ in the lungs of deer

Nature 202, 715-716 (1964) NSA 18, 25693

PENNEMAN, R. A., and L. J. Johnson

Experience with handling transuranium elements at Los Alamos

71-PER

In: Radiation Protection Problems Relating to Transuranium Elements

(Doc. EUR-4612) 327-351 (1971) NSA 25, 37798

PENTREATH, R. J.

The metabolism of radionuclides

In: Marine Radioecology (Organization for Economic Co-operation and

Development, Paris) 97-i26 (1972) NSA 29, 827 PD $\underline{8}, 1481$

PERKINS, R. W. See: 67-THC

PERLYUK, M. F. See: 71-ZLO

PERSING, R. L. See: 62-BUS

PERSSON, R. B. R. See: 75-HOM

PESTERNIKOV, V. M., and Z. M. Bukhtoyarova

Dynamics of the $239 \mathrm{Pu}$-induced osteosarcoma growth rate (in Russian)

72-PES

Med. Radiol. 17 (3), 19-24 (1972) NSA 26, 43378

PESTERNIKOV, V. M.

Determination of maximum permissible plutonium 239 level

72-PET according to the osteosarcomogenic effect

In: Biological Effects of Radiation from External and Internal

Sources (Y. I. Moskalev and V. S. Kalistratova, eds., Meditsina,

Moscow) 265-270 (1972) translated in AEC-tr-7457, 391-397

NSA $\underline{30}, 9968$

PESTERNIKOV, V. M. See also: 72-BUL, 71-LEV, 72-LEV

PETAVY, G. See: 70-KUN, 70-LUT

PETERMANN, P. See: 66-TAG

PETROVICH, I. K. See: 67-MOS-2, 71-MOS, 71-MOS-3, 72-MOS-4, 73-MOS-4, 74-MOS, 74-MOS-2, 68-ZAL, 69-ZAL, 72-ZAL-2, 74-ZAL

PEYRESBLANQUES, H. See: 70-ROD

PHELPS, P. L. See: 73-ANS

PHEMISTER, R. D. See: 75-DAG, 75-DAG-2

PHILLIPS, C. R. See: 71-SHE

PICKRELL, J. A. See: 72-THR-2 
PIERCE, $M$.

48-PIE

The gastrointestinal tract

In: Histopathology of Irradiation from External and Internal Sources

(w. Bloom, ed., McGraw Hill, New York) 502-540 (1948)

PIGFORD, T. H.

Environmental aspects of nuclear energy production

74-PIG

Annu. Rev. Nucl. Sci. 24, 515-559 (1974) NSA 31, 16528

PIGFORD, T. H. See also: 74-GAV

PILLAI, K. C., R. C. Smith and T. R. Folsom

64-PIL

Plutonium in the marine environment

Nature 203, 568-571 (1964) NSA 18, 39108

PILLERON, J. P., H. Jammet, J. Lafuma, J. Manquene and R. Gongora Concerning a case of deep injury caused by foreign bodies heavily contaminated by $239 \mathrm{Pu}$. Decontamination surgery under surveillance of a nuclear detection device (in French)

Mem. Acad. Chir. 90, 323-329 (1964) NSA 19, 33973

PILTINGSRUD, C. W. See: 65-LAG, 67-LAG-2, 65-PLIT

PIWNICA, A, See: 73-LAU

PLANAS-BOHNE, $F$., and $H$. Ebe 1

Dependence of DTPA-toxicity on the treatment schedule

Health Phys. 29, 103-106 (1975) NSA 32, 28322

PLESKOVA, A. See: 71-TRN

PLOTNIKOVA, L. A., and G. D. Baisogolov

The effect of $\mathrm{Na}_{3} \mathrm{Ca}-\mathrm{DTPA}$ (pentacene) on the excretion of $\mathrm{Pu}^{239}$

from the human organism

Med. Radiol. 9(1), 49-52 (1964) translated in JPRS-23566, 9-13

NSA $18,13431^{-1}$

PODA, G. A. See: 72-J0Y, 69-VER

PODGORODETSKAYA, V. N. SEe: 64-BAD

POET, S. E., and E. A. Martell

Plutonium-239 and $241 \mathrm{Am}$ contamination in the Denver area

Health Phys. 23, 537-548 (1972) NSA 26, 56113

POET, S. E., and E. A. Martell

Reply to "Plutonium-239 contamination in the Denver area"

by $P$. W. Krey

Health Phys. 26, 120-122 (1974) NSA 29, 15598

POLIG, E. See: 72-VOL

POLZER, W. L.

Solubility of plutonium in soil/water environments

In: Proceedings of the Rocky Flats Symposium on Safety in Plutonium

Handling Facilities (Doc. CONF-710401) 411-429 (1971) NSA 25, 54756

POND, S. F. See: 67-JOI

POPLYKO, M. G., and N. A. Koshurnikova

Long-term consequences of chronic inhalation of plutonium citrate (Abstract)

Radiobiologiya 14, 464 (1974) translated in AEC-tr-7596, 195

POPLYKO, M. G. See also: 74-BUK, 72-KOS, 72-KOS-2, 73-KOS-3, 73-KOS, 74-TEA 
POPOV, B. A.

73-POV

Influence of pentacin on the acceleration of the elimination of

24. Am from the rat organism (Abstract)

Radiobiologiya 13, 154 (1973) translated in AEC-tr-7430, 214

PD $\underline{7}, 982 T$

POPOV, B. A. See also: 72-ZAL, 73-ZAL

POPPLEWELL, D. S., and G. Boocock

Distribution of some actinides in blood serum proteins

$68-\mathrm{POL}$

In: Diagnosis and Treatment of Deposited Radionuclides (H. A. Kornberg

and W. D. Norwood, eds., Excerpta Medica Foundation, Amsterdam)

45-55 (1968) NSA 23, 24629

POPPLEWELL, D. S., G. Boocock, D. M. Taylor and C. J. Danpure

Subcellular distribution of americium and curium in rat liver

71-POL

In: Radiation Protection Protlems Relating to Transuranium Elements

(Doc. EUR-4612) 205-222 (1971) NSA 25, 37720

POPPLEWELL, D. S.

The chemistry of plutonilim incorporated in humans

Radio1. Prot. Bu11. No. 3, 13-16 (1973) NSA 28, 6079

POPPLEWELL, D. S.

Plutonium uptake by cell cultures in presence of some chelating

73-POL-2 agents

Health Phys. 25, 413-420 (1973) NSA 28, 30289

POPPLEWELL, D. S. See also: 65-BOC, 66-BOC, 70-BOC

POROZOV, N. V. See: 74-DOE, 74-DOE-2

POST, J. See: 57-FOR

POSTEL, S. See: 47-ABR

POTTER, T. See: 72-CAL

POTTS, A. M. See: 47-ABR

PRASAD, N. See: 70-BUC, 72-DEF, 73-BUC

PRATT, M. W. SEe: 68-NGY

PRICE, K. R.

Critical review of biological accumulation, discrimination, and uptake of radionuclides important to waste management practices, 1943-1971

Doc. BNWL-B-148, 67 p. (1971) PD $\underline{6}, 3289$

PRICE, K. R.

Uptake of $237 \mathrm{~Np}, 239 \mathrm{Pu},{ }^{241} \mathrm{Am}$ and ${ }^{244} \mathrm{Cm}$ from soil by tumbleweed and cheatgrass

Doc. BNWL-1688, 14 p. (1972) NSA 27, 5570

PRICE, K. R.

Tumbleweed and cheatgrass uptake of transuranium elements applied to soil as organic acid complexes

Doc. BNWL- 1755,10 p. (1973) NSA 28, 21108

PRICE, K. R.

Transuranic elements in soils, plants, and animals

73-POL

J. Environ. Qual. 2, 62-66 (1973) NSA 28, 385

PRINE, J. R. See: 74-ANE 
PROSSER, C. L.

47-PRO

The clinical sequence of physiological effects of ionizing radiation in animals

Radiology 49, 299-313 (1947) BA 22, 10794

PROSSER, C. L., and M. N. Swift

An interspecies comparison of the radiotoxicity of $X$-ray, strontium89 , and plutonium-239

Doc. AECD-2828 (CH-3893), 10 p. (1949) EP S2, 40

PROSSER, C. L. See also: 45-COK, 45-COK-2, 46-PAE

PROUT, W. E.

Adsorption of radioactive wastes by Savannah River Plant soil

$58-P R W$

Soil Sci. 86, 13-17 (1958) NSA 12, 13076

PURTYMUN, W. D.

Plutonium in stream channel alluvium in the Los Alamos area, New Mexico

Doc. LA-4561, 7 p. (1970) NSA 25, 15762

PURTYMUN, W. D. See also: 74-HAK-2, 70-KEN, 71-KEN

PUTZIER, E. A., C. R. Lagerquist, S. E. Hamenond, J. R. Mann and

49-PRO C. W. Piltingsrud

Evaluation and treatment of an acute internal exposure to plutonium In: Personnel Dosimetry for Accidental High-Level Exposure to External and Internal Radiation (International Atomic Energy Agency, Vienna) 549-566 (1965) NSA 19, 26579

PUTZIER, E. A. See also: 64-HAS, 65-LAG, 67-LAG-2

PUZYREV, A. A., and A. P. Nifatov

Microdistribution of americium 241 in some rat organs following

intraperitoneal and intratracheal administration of this isotope In: Biological Effects of Radiation from External and internal Sources (Y. I. Moskalev and V. S. Kalistratova, eds., Meditsina, Moscow) 298-302 (1972) translated in AEC-tr-7457, 435-440 NSA 30, 10017 PD $8,664 \mathrm{~T}$

PUZYREV, A. A. See also: 69-ERO, 71-ERO, 68-KOS, 71-KOS-2 
RAABE, O. G., H. A. Boyd, G. M. Kanapil1y, C. J. Wilkinson and

G. J. Newton

Development and use of a system for routine production of monodisperse particles of $238 \mathrm{PuO}_{2}$ and evaluation of gamma-emitting labels

Health Phys. 28, 655-667 (1975) NSA 32, 16898

RAABE, 0. G. See a 1so: 74-KAN

RADASCH, C. A. See: 68-SCL

RADWAN, I. See: 73-JAW

RAFTER, J. J. See: 73-HAW

RAGAN, H. A. See: 68-SMV

RAHMAN, Y. E., and A. Lindenbaum

Lysosome particles and subcellular distributions of polymeric

64-RAH tetravalent plutonium-239

Radiat. Res. 21, 575-583 (1964) NSA 18, 19669

RAHMAN, Y. E., M. W. Rosenthal and E. A. Cerny Intracellular plutonium: Removal by liposome-encapsulated chelating agent

Science 180, 300-302 (1973) NSA 27, 28038

RAJU, M. R., and J. H. Jett

RBE and OER variations of mixtures of plutonium alpha particles and $X$-rays for damage to human kidney cells (T-1)

Radiat. Res. 60, 473-481 (1974) NSA 31, 8817

RAKOVA, V. A. See: 70-ERS, 71-OSA, 71-0SA-3

RAMIS, C. A. See: 70-ALV, 68-FOW

RAMOS, E. See: 69-IRA, 73-LAD

RAMSDEN, D., and R. G. Speight

The measurement of $239 \mathrm{Pu}$ in vivo. A progress report

In: Diagnosis and Treatment of Deposited Radionuclides (H. A. Kornberg and W. D. Norwood, eds., Excerpta Medica Foundation, Amsterdam) 171-188 (1968) NSA 23, 24636

RAMSDEN, D.

The measurement of $239 \mathrm{Pu}$ in vivo

Hea1th Phys. 16, 145-153 (1969) NSA 23, 14212

RAMSDEN, D., M. E. D. Bains and D. C. Fraser In-vivo and bioassay results from two contrasting cases of plutonium-239 inhalation

Hea1th Phys. 19, 9-17 (1970) NSA 24, 44502

RAMSDEN, D., and D. A. Waite Inhalation of insoluble iron-oxide particles in the submicron range

In: Assessment of Radioactive Contamination in Man (International Atomic Energy Agency, Vienna) 65-81 (1972) NSA 26, 56520

RAMSDEN, D. See a1so: 70-DEA, 64-SPE

RANNAUD, J. C. See: 70-KUN, 70-LUT

REDISKE, J. H, J. F. Cline and A. A. Selders

The absorption of fission products by plants

74-RAJ

68-RAM

69-RAM

70-RAM

72-RAM 
REHFELD, C. E., B. J. Stover, G. N. Taylor and C. W. Mays

Fracture incidence in beagles receiving single injections of radium or plutonium

In: Some Aspects of Internal Irradiation (T. F. Dougherty, et al.,

eds., Pergamon Press, New York) 131-143 (1962) NSA 17, 19891

REHFELD, C. E. See also: 62-CHR, 62-D0T, 62-TAG, 62-TAG-2, 66-TAG, 69-TAG-2, 62-TAD

REIDEMEISTER, C. See: 73-LAU

REPIN, V. S. See: 74-LIK

RESHETOV, G. N. See: 64-ERO, 64-MOS, 66-MOS-2, 66-MOS-3

RETHERFORD, J. C. See: 74-BRA

RHOADES, R. P.

Structures accessory to the gastrointestinal tract

In: Histopathology of Irradiation from External and Internal

Sources (W. Bloom, ed., McGraw Hill, New York) 541-549 (1948)

RHOADES, R. P.

$48-\mathrm{RHO}-2$

The adrenal

In: Histopathology of Irradiation from External and Internal

Sources (W. Bloom, ed., McGraw Hill, New York) 736-739 (1948)

RHODES, D. W.

Absorption of plutonium by soil

Soil Sci. 84, 465-471 (1957) NSA 12, 17014

RICCI PIERMATTEI, S. See: · 73-PAF

RICHMOND, C. R., J. E. London, J. S. Wilson and J. Langham

Biological response to small discrete highly radioactive sources.

I. Observations on gastrointestinal transit, histological

change, and tissue deposition in beagles fed one-half curie

$238 \mathrm{PuO}_{2}$ for 6 months

Health Phys. 15, 487-492 (1968) NSA 23, 7950

RICHMOND, C. R., J. Langham and R. S. Stone

70-RIC

Biological response to small discrete highly radioactive sources.

II. Morphogenes is of microlesions in rat lungs from

intravenously injected $238 \mathrm{PuO}_{2}$ in microspheres

Health Phys: 18, 401-408 (1970) NSA 24, 27510

RICHMOND, C. R.

Program planning in inhalation carcinogenesis: USAEC plans

57-RHD

In: Inhalation Carcinogenes is (M. G. Hanna, et al., eds.,

Doc. CONF-691001) 483-497 (1970) PD $\underline{4}, 4136$

RICHMOND, C. R.

Human experience as related to plutonium

In: Plutonium Information Meeting for an Ad Hoc Subcomnittee

of the Advisory Committee on Reactor Safeguards, Doc. CONF-

$740115,87-96$ (1974) NSA 31, 14403

RICHMOND, C. R.

Biomedical effects of plutonium on humans (part of AEC presentation

68-RIC

at EPA Plutonium Standards Hearings, December 10-11, 1974)

In: Doc. WASH-1359, 235-269 (1974) NSA 31, 16861

RICHMOND, C. R. See also: 74-ANE, 74-BAI-3, 72-BUS, 74-HEA-2, 73-HEM, 73-HEM-2, 74-HEM

ROBERTS, L. SEe: 74-TAG 
ROBERTSON, D. E.

Influence of the physico-chemical forms of radionuclides and stable trace elements in seawater in relation to uptake by the marine biosphere

In: Marine Radioecology (Organization for Economic Cooperation and Development, Paris) 21-93 (1972) NSA 29, 399

ROBERTSON, D. M. See: 71-COR

ROBERTSON, J. S., and S. H. Cohn

$64-\mathrm{ROB}$

Evaluation of plutonium exposures in man

Health Phys. 10, 373-389 (1964) NSA 18, 29298

ROBERTSON, J. S. See also: 70-ATK, 72-ATK, 64-COS, 73-FAI

RODIER, J., J. Chassany, R. Estournel and H. Peyresblanques

Twelve years of health physics in a plutonium production plant

70-ROD

(in French)

Arch. Ma1. Prof. Med. Trav. Secur. Sociale, 31, 9-22 (1970)

NSA 25,4526

RODRIGUEZ, E. R.

Palomares two years after

In: Radiological Protection of the Public in a Nuclear Mass Disaster, Proceedings of a Symposium, Interlaken, Switzerland, 1968 (H. Brunner and S. Pretre, eds., Fachverband fuer Strahlenschutz) 36-38 (1968)

NSA 23, 20181

RODRIGLIEZ, E. R. See also: 68-FOW

ROESCH, W. C., and J. W. Baum

$58-R 0 E$

Detection of plutonium in wounds

In: Proceedings of the Second United Nations International Conference on the Peaceful Uses of Atomic Energy, Vol. 23. Experience in

Radiological Protection (United Nations, Geneva) 142-143 (1958)

NSA 12,14615

ROESCH, W. C., and H. E. Palmer

Detection of plutonium in vivo by whole body counting

$62-\mathrm{ROE}$

Health Phys. $\underline{8}, 773-776$ (1962) NSA 17, 13882

ROGACHEVA, S. A. See: 62-BOG

ROIZIN-TOWLE, L. A. See: 71-HAZ, 74-HAZ

ROMNEY, E. M., H. M. Mork and K. H. Larson

Persistence of plutonium in soil, plants and small animals

70-ROM

Health Phys. 19, 487-491 (1970) NSA 25, 4478

ROMNEY, E. M., and J. J. Davis

Ecological aspects of plutonium dissemination in terrestrial environments

Health Phys. 22, 551-557 (1972) NSA 26, 38419

ROMNEY, E. M., A. Wallace, R. 0. Gilbert, S. A. Bamberg, J. D.

Childress, J. E. Kinnear and T. L. Ackerman

Some ecological attributes and plutonium contents of perennial vegetation in area 13

Doc. UCLA-12-937, 19 p. (1973) NSA 29, 10129

ROMNEY, E. M., A. Wallace, R. 0. Gilbert and J. E. Kinnear $239-240 \mathrm{Pu}$ and $241 \mathrm{Am}$ contamination of vegetation in aged plutonium fallout areas

Doc. UCLA-12-986, 52 p. (1975) NSA 31,29626

ROMNEY, E. M. See also: 65-NIS, 74-WAC 
ROSE, D. J.

74-ROX

Nuclear eclectic power

Science 184, 351-359 (1974)

ROSE, D. J. See also: 73-KLIB

ROSEN, J. C., N. Cohen and M. E. Wrenn

$72-\mathrm{ROJ}$

Short term metabolism of $241 \mathrm{Am}$ in the adult baboon

Health Phys. 22, 621-626 (1972) NSA 26, 38773

ROSEN, J. C. See also: 72-WRE

ROSENBAUM, H. C. See: 70-GJO

ROSENBLATT, L. S. See: 72-BUS, 69-D0J, 70-D0J, 71-D0J

ROSENTHAL, M. W. (ed.)

Therapy of Radioelement Poisoning. Transcription of a Meeting on Experimental and Clinical Approaches to the Treatment of

Poisoning by Radioactive Substances (Doc. ANL-5584) 181 p. (1956)

NSA 11,893

ROSENTHAL, M. W.

The use of zirconium and other carriers in the removal of

radioelements from the body. Comments on the use of complexing agents

In: Therapy of Radioelement Poisoning (M. W. Rosentha1, ed.,

Doc. ANL-5584) 100-113 (1956)

ROSENTHAL, M. W., and J. Schubert

Kinetics of body distribution of plutonium as influence by zirconium

$57-\operatorname{ROS}$

Radiat. Res. $\underline{6}, 349-354$ (1957) NSA 11, 5754 EP S2, 218

ROSENTHAL, M. W.

Radioisotope absorption and methods of elimination: Factors

influencing elimination from the body

In: Radioisotopes in the Biosphere (R. S. Caldecott and L. A. Snyder, eds., University of Minnesota, Minneapolis) 541-563 (1960) NSA 14,

23878

ROSENTHAL, M. W., J. F. Markley, A. Lindenbaum and J. Schubert

Influence of DTPA therapy on long-term effects of retained plutonium Health Phys. 8, 741-745 (1962) NSA 17, 12128

ROSENTHAL, M. W., and A. Lindenbaum

Effect of desferrioxamine-B-methane sulfonate (DFOM) on removal of plutonium in vitro and in vivo

Proc. Soc. Expt1. Biol. Med. 117, 749-750 (1964) NSA 19, 8769

ROSENTHAL, M. W. , and A. Lindenbaum

Influence of DTPA therapy on long-term effects of retained monomeric plutonium: Comparison with polymeric plutonium

Radiat. Res. 31,506-521 (1967) NSA 21, 34577

ROSENTHAL, M. W., J. H. Marsha 11 and A. Lindenbaum

Autoradiographic and radiochemical studies of the effect of

colloidal state of intravenously injected plutonium on its

distribution in bone and marrow

In: Diagnosis and Treatment of Deposited Radionuclides (H. A. Kornberg

and W. D. Norwood, eds., Excerpta Medica Foundation, Amsterdam) 73-80

(1968) NSA 23, 24632 
ROSENTHAL, M. W., M. Smoler and A. Lindenbaum

Combined reticuloendothelial stimulation and long-term intermittent

$68-R 0 S-2$

DTPA therapy in poisoning by polymeric plutonium

In: Diagnosis and Treatment of Deposited Radionuclides (H. A. Kornberg

and W. D. Norwood, eds., Excerpta Medica Foundation, Amsterdam)

403-412 (1968) NSA 23, 24548

ROSENTHAL, M. W., J. J. Russe11, E. S. Moretti and A. Lindenbaum Effective dose of DTPA, spaced at 3 day intervals, in removal of skeletal plutonium

Hea 1 th Phys. $16,806-808$ (1969) NSA 23, 35711

ROSENTHAL, M. W. , and A. Lindenbaum

Osteosarcomas as related to tissue distribution of monomeric and polymeric plutonium in mice

In: Delayed Effects of Bone-Seeking Radionuclides (C. W. Mays,

et a1., eds., University of Utah Press, Salt Lake City) 371-386

(1969) NSA 23, 38801

ROSENTHAL, M. W., E. Moretti, J. J. Russell and A. Lindenbaum Marrow deposition and distribution of monomeric and polymeric $239 \mathrm{Pu}$ in the mouse, estimated by use of $59 \mathrm{Fe}$

Health Phys. 22, 743-748 (1972) NSA 26, 38788

ROSENTHAL, M. W., A. Lindenbaum, J. J. Russe11, E. Moretti and

D. Chladek

Metabolism of monomeric and polymeric plutonium in the rabbit. Comparison with the mouse

Hea ith Phys. 23, 231-238 (1972) NSA 26, 45917

ROSENTHAL, M. W., H. Brown, D. L. Chladek, E. S. Moretti, J. J.

Russe 1 and $A$. Lindenbaum

Removal of plutonium from mouse 1 iver by glucan and DTPA

Radiat. Res. 53, 102-114 (1973) NSA 27, 22807

ROSENTHAL, M. W. See also: 73-BAX, 73-BAX-2, 62-LIN, 68-LIN, 68-LIN-2, 72-LIN, 62-MAR, 64-MAR, 73-RAH, 61-SCH-2

ROSOFF, B. See: 62-STE

ROSS, D. M.

A statistical summary of USAEC contractors' internal exposure experience 1957-1966

In: Diagnosis and Treatment of Deposited Radionuclides ( $H$. A. Kornberg

and W. D. Norwood, eds., Excerpta Medica Foundation, Amsterdam) 427-

434 (1968) NSA 23,24645

ROSSI, H. H. See: 71-HAZ, 74-HAZ-2

ROWDEN, G., and A. C. James An electron-microscope-autoradiographic investigation of the localization of $241 \mathrm{Pu}$ in rat liver

Biochem. J. 111, 36P - 37P (1969) NSA 23, 50326

ROWDEN, G. See also: 69-JAM

ROWLAND, R. E., and E. Lloyd Deposition patterns of bone-seeking isotopes in man

In: Environmental Contamination by Radioactive Materials (International

Atomic Energy Agency, Vienna) 63-72 (1969) NSA 24, 7721 
ROWLAND, R. E., A. T. Keane and H. F. Lucas, Jr.

A preliminary comparison of the carcinogenicity of ${ }^{226} \mathrm{Ra}$ and

73-ROL

$228 \mathrm{Ra}$ in man

In: Radionuclide Carcinogenes is (C. L. Sanders, et al., eds.,

Doc. CONF-720505) 406-420 (1973) NSA 28, 18537; PD $\underline{7}, 4647$

ROWLAND, R. E. See also: 72-BUS, 68-LOE

ROYSTER, G. W. See: 67-FIS

R0ZZELL, T. C. See: 70-AND

RUDNITSKAYA, E. I., and Y. I. Moskalev

Microdistribution and morphological changes in rats in the case

of intravenous injection of $241 \mathrm{Am}$

Radiobiologiya 10, 570-574 (1970) translated in AEC-tr-7205, 138-145

NSA 25, 10942

RUDNITSKAYA, E. I.

Morphology of some processes at remote times accompanying ${ }^{241} \mathrm{Am}$ damage

In: Remote Aftereffects of Radiation Damage (Y. I. Moskalev, ed., Atomizdat, Moscow) 406-414 (1971) translated in AEC-tr-7387, 447454 PD 7, 362T

RUDNITSKAYA, E. I., and Y. I. Moskalev

Effects of subacute-effective doses of ${ }^{241} \mathrm{Am}$ on rabbits

Radiobiologiya 12,788-791 (1972) translated in AEC-tr-7415, 205-209 NSA 27, 27998

RUDNITSKAYA, E. I .

Characteristics of microdistribution and morphological changes

in dogs with damage induced by americium 241

In: Biological Effects of Radiation from External and Internal

Sources (Y. I. Moskalev and V. S. Kal istratova, eds., Meditsina,

Moscow) 324-331 (1972) translated in AEC-tr-7457, 475-485

NSA 30,9974

RUDNITSKAYA, E. I.

Some aspects of thyroid and parthyroid damage due to americium 241

72-RUD-3

In: Biological Effects of Radiation from External and Internal

Sources (Y. I. Moskalev and V. S. Kalistratova, eds., Meditsina,

Moscow) 331-334 (1972) translated in AEC-tr-7457, 486-490

NSA 30,9975

RUDNITSKAYA, E. I., and Y. I. Moskalev

Somatic effects in the action of $241 \mathrm{Am}$ on animals (in Russian)

71-RUD

Gig. Sanit. (4), 46-50 (1974) NSA 30, 24311

RUDNITSKAYA, E. I. See a 150: 67-MOS-2, 71-MOS, 71-MOS-4, 72-MOS-4, 73-MOS-4, 74-MOS, 74-MOS-3, 69-ZAL

RUDOLPH, A. W., T. E. Carrol1 and R. S. Davidson

Plutonium and its effects in the environment - a selected

literature survey

Doc. TID-26130, 203 p. (1971) NSA 26, 48058

RUHMANN, A. G., and D. L. Berliner

Serum lactic dehydrogenase levels in adult beagle dogs with

internally deposited radionuclides

Radiat. Res. 26, 287-294 (1965) NSA 20, 112 
RUNDO, J., B. T. Taylor, D. V. Bocker, D. Newton and D. Seargil1

68-RUN Attenuation in the chest wall of $20 \mathrm{keV} X$ rays from an inhaled radioactive aerosol

Nature 217, 642-643 (1968) NSA 22, 21501

RUNDO, J., A. T. Keane and H. A. May

Measurement of ${ }^{241} \mathrm{Am}$ in a 10-year old boy

In: Assessment of Radioactive Contamination in Man (International

Atomic Energy Agency) 579-594 (1972) NSA 26, 56536

RLINDO, J., and J. Sedlet

Retention and elimination of berkelium-24l - californium-249

following acute accidental inhalation

In: Proc. Third Int. Radiat. Prot. Assn. (W. S. Snyder, ed., Doc.

CONF-730901-P1) Vol. 1,731-735 (1974) NSA 30, 27236

RUND0, J. See also: 70-DEA, 71-NED

RUSSELL, E. R., H. Delaney, E. Motta, J. Muntz, E. S. G. Barron,

E. E. Painter, R. Edwards, O. France, C. W. Hagen and S. Schwartz Effects of product upon dogs

In: Doc. CN-2786, 18-28 (1945) EP 5, 188

RUSSELL, E. R., and J. J. Nickson

Distribution and excretion of plutonium

In: Industrial Medicine on the Plutonium Project (R. S. Stone, ed., McGraw-Hill, New York) 256-263 (1951) EP S2, 84

RUSSELL, E. R. See also: 45-COK-2, 45-LAN, 46-PAE

RUSSELL, J. J. See: 73-BAX, 72-LIN-2, 69-ROS. 72-ROS, 72-ROS-2, 73-ROS

RUSSELL, R. S.

The extend and consequences of the uptake by plants of radioactive nucl ides

Ann. Rev. Plant Physiol. 14, 271-294 (1963) NSA 18, 9821

RUSSELL, R. S.

Behavior of radioactive materials in soil

In: Radioactivity and Human Diet (R. S. Russe11, ed., Pergamon Press,

New York) 105-126 (1966) NSA 21, 43323

RUSSELL, R. S.

Other fission products, induced activities, and fissile materials

In: Radioactivity and Human Diet (R. S. Russell, ed., Pergamon Press,

New York) 353-363 (1966) NSA 21, 43414

RYSINA, T. N.

Plutonium distribution and excretion in dogs at different periods of time

Med. Radiol. 5(11), 49-53 (1960) translated in JPRS 11907, 80-86

NSA $15,10631^{-1}$

RYSINA, T. N., and R. A. Erokhin

The distribution and excretion of plutonium in dogs at remote dates after its introduction

In: Biological Effects of Radiation and Problems of Radioactive

Isotope Distribution (A. V. Lebedinski $i$ and $Y$. I. Moskalev, eds. Atomizdat, Moscow) 119-127 (1961) translated in AEC-tr-5265, 117-

126 NSA 16, 26719 
RYSINA, T. N., and R. A. Erokhin

62-RYS

Distribution and excretion of plutonium at remote periods after administration to dogs

In: Plutonium-239: Its Distribution, Biological Effect and Accelerated

El imination (A. V. Lebedinksii and Y. I. Moskalev, eds., Medgiz, Moscow)

12-18 (1962) translated in FTD-TT-63-559, 8-18 NSA 17, 30270

RYSINA, T. N., and I. A. Tseveleva

$62-$ RYS-2

Transmission of plutonium to offspring

In: Plutonium-239: Its Distribution, Biological Effect and

Accelerated Elimination (A. V. Lebedinski $i$ and $Y$. I. Moskalev, eds., Medgiz, Moscow) 41-44 (1962) translated in FTD-TT-63-559, 52-57 NSA 17, 30274

RYSINA, T. N., V. K. Lemberg and I. A. Tseveleva

71-RYS Biochemical and morphological changes in the lungs of rats accompanying multiple inhalation of a plutonium citrate aerosol In: Remote Aftereffects of Radiation Damage (Y. I. Moskalev, ed., Atomizdat, Moscow) 333-340 (1971) translated in AEC-tr-7387, 364370 PD $\underline{7}, 2071$ EP $\underline{5}, 189$

RYSINA, T. N. See also: 68-TSE, 71-TSE 
SACHER, G. See: 46-PAE

SAFRONOV, E. I.

72-SAF

Radiation Sickness from Internal Irradiation, Izdatel'stvo

Meditsina Leningradskoe Otdelenie, Leningrad, 136 p. (1972)

NSA 28, 719

SAGAN, L. A. See: 70-COD

SAKANOUE, M., and T. Tsuji

Plutonium content of soil at Nagasaki

Nature 234, 92-93 (1971) NSA 26, 6799 PD 6, 212

SAKANOLIE, M., M. Nakaura, and T. Ima $i$

Determination of plutonium in environmental samples

In: Rapid Methods for Measuring Radioactivity in the Environment

(International Atomic Energy Agency, Vienna) 171-181 (1971)

NSA 26, 27807

SAKANOLIE, M. See also: 70-INO

SAN PIETRO, A. See: 47-CAR

SANDBERG, G. W., Jr., R. C. Lee, C. A. S. Pegg, F. N. Huffman, and

J. C. Norman

Simulated radiation fields from $238 \mathrm{Pu}$-fueled artificial hearts:

Long-term effects of intracorporeal $90 \mathrm{Sr}, 241 \mathrm{Am}$, and Be sources

Surg. Forum 20, 194-196 (1969) NSA 24, 17147

SANDBERG, G. W., Jr., F. A. Molokhia, F. N. Huffman and J. C. Norman Implantable nuclear power sources for artificial organs: Preliminary pathologic effects

Surg. Forum 21, 198-200 (1970) EP S2, 383

SANDBERG, G. See a lso: 69-NOM

SANDERS, C. L.

Phagocytosis and translocation of ${ }^{23}{ }^{9} \mathrm{PuO}_{2}$ particles by peritoneal phagocytes of the rat

In: Diagnosis and Treatment of Deposited Radionuclides ( $H$. A.

Kornberg and W. D. Norwood, eds., Excerpta Medica Foundation,

Amsterdam) 81-90 (1968) NSA 23, 24533

SANDERS, C. L., and R. R. Adee

Phagocytosis of inhaled plutonium oxide- $239 \mathrm{Pu}$ particles by pulmonary macrophages

Science $162,918-920(1968) \quad$ NSA 23,6375

SANDERS, C. L., and R. R. Adee

The ultrastructure of mononuclear phagocytes following

intraperitoneal administration of $239 \mathrm{PuO}_{2}$ particles

J. Reticuloendothe1. Soc. $6,1-23$ (1969) NSA 23, 45873

71-SAK

$71-S A K-2$

69-SAG

SANDERS, C. L.

The distribution of inhaled $239 \mathrm{PuO}_{2}$ particles within pulmonary macrophages

Arch. Environ. Health 18, 904-912 (1969) NSA 23, 31732

SANDERS, C. L.

The biological behavior of ${ }^{2}{ }^{39} \mathrm{PuO}_{2}$ particles: Role of the

peritoneal mononuclear phagocyte

Radiat. Res. 38, 125-139 (1969) NSA 23, 22419 
SANDERS, C. L.

70-SAN

Maintenance of phagocytic function following ${ }^{239} \mathrm{PuO}_{2}$ particle administration

Health Phys. 18, 82-85 (1970) NSA 24, 11925

SANDERS, C. L., and W. J. Bair

The effect of DTPA and calcium on the translocation of

intraperitoneally administered $239 \mathrm{PuO}_{2}$ particles

Health Phys. 18, 169-173 (1970) NSA 24, 16952

SANDERS, C. L., Jr., R. C. Thompson and W. J. Bair

Lung cancer: Dose response studies with radionuclides

70-SAN-3

In: Inhalation Carcinogenes is (M. G. Hanna, Jr., et al., eds.,

Doc. CONF-691001) 285-303 (1970) NSA 24, 27674

SANDERS, C. L., and R. R. Adee

Ultrastructural localization of inhaled ${ }^{239} \mathrm{PuO}_{2}$ particles in alveolar epithelium and macrophages

Hea1th Phys. 18, 293-295 (1970) NSA 25, 34054

SANDERS, C. L., R. R. Adee and T. A. Jackson

Fine structure of alveolar areas in the lung following inhalation of $239 \mathrm{PuO}_{2}$ particles

Arch. Environ. Health 22, 525-533 (1971) NSA 25, 32539

SANDERS, C. L., and J. F. Park

Pulmonary distribution of $\alpha$ dose from $239 \mathrm{PuO}_{2}$ and induction of neoplasia in rats and dogs

In: Inhaled Particles III. (W. H. Walton, ed., Unwin Brothers, 0ld

Woking, England) 489-497 (1971) NSA 26, 12510

SANDERS, C. L.

Deposition patterns and the toxicity of transuranium elements in lung

Health Phys. 22, 607-615 (1972) NSA 26, 38771

SANDERS, C. L., and T. A. Jackson

Induction of mesotheliomas and sarcomas from hot spots of $239 \mathrm{PuO}_{2}$ activity

Health Phys, 22, 755-759 (1972) NSA 26, 38746

SANDERS, C. L.

Cocarcinogenesis of $239 \mathrm{PuO}_{2}$ with chrysotile asbestos or benzpyrene in the rat abdominal cavity

In: Radionuclide Carcinogenesis (C. L. Sanders, et al., eds., Doc.

CONF-720505) 138-153 (1973) NSA 28, 18551

SANDERS, C. L., Jr.

Toxicology of inhaled $238 \mathrm{pu}$ in rats

IRCS Int. Res. Commun. System (73-4) 28-8-2 (1973)

SANDERS, C. L., and D. M. Meier

Effects of DTPA on excretion and tissue distribution of injected

$238 \mathrm{Pu}$ in fed and fasting rats

Health Prys. 25, 405-411 (1973) NSA 28, 30342

SANDERS, C. L.

Carcinogenicity of inhaled $238 \mathrm{pu}$ in the rat

$70-$ SAN -5

$70-$ SAN-2

71-SAN

$71-$ SAN-2

72-SAN

Radiat. Res. 56, 540-553 (1973) NSA 29, 16051

73-SAN-4

SANDERS, C. L.

74-SAN

Rat mammary neoplasia following deposition of plutonium

Health Phys. 27, 592-593 (1974) NSA 31, 23058 
SANDERS, C. L., and G. E. Dagle

74-SAN-2

Studies of pulmonary carcinogenesis in rodents following inhalation of transuranic compounds

In: Experimental Lung Cancer. Carcinogenesis and Bioassays (E. Karbe and J. F. Park, eds., Springer-Verlag, Berlin) 422-429 (1974)

SANDERS, C. L.

Effects of $\mathrm{PuO}_{2}$ particles deposited in the lung following

intraperitoneal injection

Health Phys. 28, 84-86 (1975) NSA 31, 23060

SANDERS, C. L., Jr.

Dose distribution and neoplasia in the lung following

intratracheal instillation of ${ }^{239} \mathrm{PuO}_{2}$ and asbestos

Health Phys. 28, 383-386 (1975) NSA $\underline{32}, 3763$

SANDERS, C. L. See also: 68-ADE, 72-BAI, 73-BAI, 72-HLIF

SANDERS, S. M., Jr.

Power functions relating excretion to body burdens

60-SAM

Health Phys. 2, 295-303 (1960) NSA 14, 10706

SANDERS, S. M., Jr.

Plutonium excretion

Arch. Environ. Health 2, 474-483 (1961) NSA 15, 15355

SANDERS, S. M., Jr., and M. Brown

Breath ionization from radionuclides deposited in the lungs

Health Phys. 14, 431-438 (1968) NSA 22, 51622

SANDERS, S. M., Jr.

Excretion of ${ }^{241} \mathrm{Am}$ and ${ }^{244} \mathrm{Cm}$ following two cases of accidental inhalation

Hea1th Phys. 27, 359-365 (1974) NSA $\underline{31}, 6371$

SANDERS, S. M., Jr. See also: 57-GEI

SANSOM, B. F.

The transfer of plutonium-239 from the diet of a cow to its milk

Brit. Vet. J. 120, 158-161 (1964) NSA 18, 29206

SANSOM, J. M. See: 74-BLM

SARYCHEV, V. A. See: 72-KHO

SAUROV, M. M. See: 71-GNE-2

SAXBY, W. N. See: 68-JON

SAYEG, J. A. See: 68-BRO, 69-BUA

SCHAEFFER, R.

Calculation of the soluble fraction of inhaled bone-seeking element

compounds in the organism liquids from changes in urinary excretion with time (in French)

In: Contamination by Bone-Seeking Radionuclides and Radioprotection,

(Societe Francaise de Radioprotection, Montrouge, France) 670-683

(1971) NSA 26, 25902

SCHAFFER, R. See: 47-CAR

SCHALLBERGER, J. A.

Plutonium lymph relationship

Doc. C00-1787-24, 167 p. (1974) NSA 31,8972

SCHELL, W. R. See: 75-NEA 
SCHIAGER, K. J.

Alpha-active fallout particles; physical characteristics related to pulmonary exposure

Thesis, Univ. of Michigan, Ann Arbor, 123 p. (1964) NSA 20, 1602

SCHIEFERDECKER, H. See: 74-KOE, 73-OHL

SCHNAP, B. See: 47-CAR

SCHNEEBELI, G. See: 62-TAG-2

SCHNEIDER, V. M. See: 71-KIY

SCHNELL, E. See: 72-CAL

SCHOFIELD, G. B.

69-SCG

Comparisons in the medical management of three cases of plutoniumcontaminated wounds

In: Handling of Radiation Accidents (International Atomic Energy

Agency, Vienna) 163-172 (1969) NSA 24, 7940

SCHOFIELD, G. B., and J. C. Lynn

A measure of the effectiveness of DTPA chelation therapy in cases of plutonium inhalation and plutonium wounds

Health Phys. 24, 317-327 (1973) NSA 27, 25034

SCHOFIELD, G. B., H. Howells, F. Ward, J. C. Lynn and G. W. Dolphin Assessment and management of a plutonium contaminated wound case

Health Phys. 26, 541-554 (1974) NSA 30, 9996

SCHOFIELD, G. B., and G. W. Dolphin

$U$. K. experience on the medical aspects of radiological protection of workers handling plutonium

Ann. Occup. Hyg. 17, 73-83 (1974) NSA 31, 20084

SCHOFIELD, G. B.

Health of plutonium workers

Lancet 2, 1456 (1974) NSA 31, 20097

SCHOFIELD, G. B. See also: 73-HOE

SCHUBERT, $J$.

Treatment of plutonium poisoning by metal displacement

Science 105, 389-390 (1947) BA 21, 22252

SCHUBERT, $J$.

An experimental study of the effect of zirconium and sodium citrate treatment on the metabolism of plutonium and radioyttrium

J. Lab. C1 in. Med. 34, 313-325 (1949) NSA 1, 1534; 2, 1757

SCHUBERT, J., M. P. Finkel, M. R. White and G. M. Hirsch Plutonium and yttrium content of the blood, liver, and skeleton of the rat at different times after intravenous administration

J. Biol. Chem. 182, 635-642 (1950) NSA 3, 1047 BA 23, 17671

SCHUBERT, J., and M. R. White

The effect of different dose levels of zirconium on the excretion and distribution of plutonium and yttrium

J. Biol. Chem. 184, 191-196 (1950) NSA 4, 4189

SCHUBERT, J. Estimating radioelements in exposed individuals. I. Radioelement metabolism

Nucleonics 8(2), 13-28 (1951) NSA 5, 1473 
SCHUBERT, J.

$51-\mathrm{SCH}-2$

Estimating radioelements in exposed individuals. II. Radiation dosage and permissible levels

Nucleonics $\underline{8}(3), 66-78$ (1951) NSA $\underline{5}, 3002$

SCHUBERT, J.

Estimating radioelements in exposed individuals. III. Bioassay operations and procedures

Nucleonics $\underline{8}(4), 59-67$ (1951) NSA $\underline{5}, 3311$

SCHIJBERT, J.

Removal of radioelements from the mammalian body

Ann. Rev. Nuclear Sci. 5, 369-412 (1955) NSA 10, 7444

SCHUBERT, J.

Approaches to treatment of poisoning by both radioactive and nonradioactive elements encountered in atomic energy operations

Proc. Int. Conf. Peaceful Uses At. Energy 13, 274-296 (1956)

SCHUBERT, J., and A. Lindenbaum

The mechanism of action of chelating agents on metallic elements

$60-\mathrm{SCH}$ in the intact animal

In: Metal Binding in Medicine (M. J. Seven, ed., J. B. Lippincott, Philadelphia) 68-74 (1960) EP S2, 283

SCHUBERT, $J$.

Radioelement removal by chelating agents: Application of mass action laws and other factors

Fed. Proc. 20, supp1. 10, 219-221 (1961) NSA 16, 31455

SCHUBERT, J., J. F. Fried, M. W. Rosenthal and A. Lindenbaum

Tissue distribution of monomeric and polymeric plutonium as modified

by a chelating agent

Radiat. Res. 15, 220-226 (1961) NSA 16, 26709

SCHUBERT, J.

Internal contamination and its treatment

In: Proceedings of the 9th International Congress of Radiology

(B. Rajewsky, ed., Georg Thieme Verlag, Stuttgart, Germany)

$1251-1257$ (1961) EP S3, 223

SCHUBERT, $J$.

Radioelement metabolism and decorporation as influenced by chelation and mixed ligand complexes: Rapid experimental and calculative approaches to predict in vivo behavior

In: Radiobiology of Plutonium (B. J. Stover and W. S. S. Jee, eds.,

J. W. Press, Salt Lake City) 355-375 (1972) NSA 26, 41302

SCHUBERT, J. See also: 59-FRI, 60-LIN, 57-ROS, 62-ROS, 52-WHI

SCHUETTELKOPF, H.

Environmental surveillance for plutonium at the Karlsruhe Nuclear

Research Center from 1969 until 1973

In: Environmental Surveillance Around Nuclear Installations. Vol.

II. (International Atomic Energy Agency, Vienna) 327-344 (1974)

NSA 31, 14043

SCHULTE, H. F., and D. D. Meyer

Control of health hazards in handling of plutonium: Results of

14 years' experience

In: Proceedings of the Second United Nations International

Conference on the Peaceful Uses of Atomic Energy, Vol. 23.

Experience in Radiological Protection (United Nations, Geneva)

206-210 (1958) NSA 12, 14722

$61-5 \mathrm{CH}-2$

$61-\mathrm{SCH}-3$

$72-\mathrm{SCH}$

$74-\operatorname{SCU}$

58-SCF 
SCHULTE, H. F., and H. O. Whipple

Chelating agents in plutonium deposition - a minority view

In: Diagnosis and Treatment of Deposited Radionuclides ( $H$. A. Kornberg and W. D. Norwood, eds., Excerpta Medica Foundation, Amsterdam) 587-592 (1968) NSA 23, 24657

SCHULTE, H. F. See also: 72-CAM, 73-CAM, 61-MOW, 69-MOW

SCHWARTZ, S. See: 45-RUE

SCHWENDIMAN, L. C., and J. W. Healy

A sensitive analytical method for the determination of very low

$58-S C L$

level plutonium in humans

In: Proceedings of the Second United Nations International Conference on the Peaceful Uses of Atomic Energy, Vol. 23. Experience in

Radioiogical Protection (United Nations, Geneva) 144-146 (1958)

NSA 12, 14616

SCHWENDIMAN, L. C., J. Mishima and C. A. Radasch

Airborne release of particles in overheating incidents involving plutonium metal and compounds

In: Treatment of Airborne Radioactive Wastes (International Atomic

Energy Agency, Vienna) 117-131 (1968) NSA 23, 29020

SCHWENDIMAN, L. C. See also: 71-MIS, 73-SEL

SCOTNIKOVA, 0. G. See: 70-LEI

SCOTT, K. G., et al.

Studies on the inhalation of fissionable materials and fission

products and their subsequent fate in rats and man

Doc. MDDC-1276 (CH-3590), 168 p. (1946) ADD 1, 1276

SCOTT, K. G., H. Fisher, D. Axelrod, J. Crowley, A. J. Barber

and J. G. Hamilton

Metabolism of plutonium in rats

Doc. MDDC-1018, 27 p. (1946) EP S3, 224 ADD 1, 1018

SCOTT, K. G., D. J. Axelrod, H. Fisher, J. F. Crowley and J. G. Hamilton

The metabolism of plutonium in rats following intramuscular injection

J. Biol. Chem. 176, 283-293 (1948) BA 23, 10188

SCOTT, K. G., D. H. Copp, D. J. Axelrod and J. G. Hamilton

The metabolism of americium in the rat

J. Bio1. Chem. 175, 691-703 (1948) NSA 1, 1389

SCOTT, K. G., D. J. Axelrod, J. F. Crowley and J. G. Hamilton Deposition and fate of plutonium, uranium and their fission products inhaled as aerosols by rats and man

Arch. Path. $\underline{48}, 31-54$ (1949) NSA $\underline{3}, 1178$

SCOTT, K. G., D. J. Axelrod and J. G. Hamilton

$49-S C K-2$

The metabolism of curium in the rat

J. Biol. Chem. 177, 325-335 (1949) BA 23, 14386

SCOTT, K. G.

Versene $\mathrm{Pu}$ complexing studies

In: Doc. AECD-3448, 5 (1952)

SCOTT, K. G. See also: 46-CRJ, 53-HAM-2, 46-LAH, 43-OVE

$46-S C K$

$46-$ SCK-2

$48-S C K$

48-SCK-2

49-SCK

SCUDDER, B. C. See: 56-NOR 
SEABORG, G. T.

Medical uses: Americium-241; californium-252

In: Uranium-Plutonium-Tranplutonic Elements (H. C. Hodge, J. N.

Stannard and J. B. Hursh, eds., Springer-Verlag, New York)

929-940 (1973) PD 8 , 129T

SEARGILL, D. See: 68-RUN

SEDLET, J. See: 74-RUN

SEIBERT, H. C. See: 46-ABR, 47-ABR

SEIDEL, A., V. Volf and A. Catsch

71-SEI

Effectiveness of $\mathrm{Zn}$-DTPA in removal of plutonium from rats

Int. J. Radiat. Biol. 19, 399-400 (1971) NSA 25, 46809

SEIDEL, A., and V. Volf

Removal of internally deposited transuranium elements by Zn-DTPA

72-SEI

Health Phys. 22, 779-783 (1972) NSA 26, 38791

SEIDEL, A.

Distribution of $239 \mathrm{Pu}$ related to different methods of preparation

of a citrate injection solution

Int. J. Appl. Radiat. Isotopes 23, 195-196 (1972) EP 5, 196

SEIDEL, A., and V. Volf

Effect of diethylenetriaminepentaacetate on the ${ }^{241} \mathrm{Am}$ content of different bones of rats (in German)

Naturwissenschaften $\underline{59}, 652$ (1972) NSA 27, 20171

SEIDEL, A.

Retention of $241 \mathrm{Am}$ by some endocrine organs of the rat and its response to DTPA treatment

Int. J. Radiat. Biol. 23, 415-416 (1973) NSA 28, 8513

SEIDEL, A.

Distribution of ${ }^{241} \mathrm{Am}$ in the rat as influenced by dose and the $\mathrm{pH}$ of the injection solution

Int. J. Appl. Radiat. Isotop. $362-363$ (1973) NSA 28, 8522

SEIDEL, A.

Comparison of the effectiveness of CaDTPA and ZnDTPA in removing $241 \mathrm{Am}$ from the rat

Radiat. Res. $\underline{54}, 304-315$ (1973) NSA 28, 8516

SEIDEL, A. A multivariate analysis of Ca-DTPA effectiveness in removing 241 Am from the rat

Z. Naturforsch. 28, 316-318 (1973) NSA 29, 815

SEIDEL, A.

Removal by DTPA of internally deposited $241 \mathrm{Am}$ : A comparative study on rats and Syrian hamsters

Int. J. Nucl. Med. Biol. 1, 197-200 (1974) NSA 30, 29822

SEIDEL, A.

Removal from the rat of internally deposited ${ }^{241}$ Am by long-term treatment with $\mathrm{Ca}-$ and $\mathrm{Zn}-\mathrm{DTPA}$

Radiat. Res. 61, 478-487 (1975) NSA 31, 29976

SEIDEL, A.

Retention of ${ }^{241} \mathrm{Am}$ in the rat and the Syrian hamster (in German)

Strahlentherapie 149, 442-449 (1975) NSA 32, 20019

SEIDEL, A. See also: 72-VOL, 74-VOL-3 
SEIGNEUR, L. J. See: 62-BUS, 58-CLA

SELBY, J. M., E. C. Watson, J. P. Corley, D. A. Waite, L. A. Carter,

73-SEL

J. G. Droppo, R. G. Clark, C. L. Brown, L. D. Williams, R. J. Hall,

L. C. Schwendiman, J. Mishima, R. K. Woodruff, T. I. McSweeney and

J. B. Burnham

Considerations in the assessment of the consequences of effluents

from mixed oxide fuel fabrication $\mathrm{plants}$

Doc. BNWL-1697, 159 p. (1973) NSA 28, 12856

SELBY, J. M. See a7so: 68-HEI

SELDERS, A. A. See: 55-RED

SEMENOV, A. I.

Biological effects of $244 \mathrm{~cm}$

Radiobiologiya 11, 134-137 (1971) translated in AEC-tr-7233,

203-207 NSA $2 \overline{5}, 44905$

SEMENOV, A. I.

Distribution of ${ }^{244} \mathrm{Cm}$ in the rat organism after intratracheal introduction (Abstract)

Radiobiologiya 11, 476 (1971) translated in AEC-tr-7303, 222

PD $\underline{6}, 603 T$

SEMENOV, A. I.

Kinetics of the exchange of ${ }^{244} \mathrm{Cm}$ (Abstract)

Radiobiologiya 11, 155 (1971) translated in AEC-tr-7233, 237-238

SEMENOV, A. I.

Distribution of curium 244 in the rat organism

In: Biological Effects of Radiation from External and Internal

Sources (Y. I. Moskalev and V. S. Kal istratova, eds., Meditsina,

Moscow) 302-305 (1972) translated in AEC-tr-7457, 441-445

NSA 30,10018

SEMENOV, A. I., Y. I. Moskalev and G. A. Zalikin Influence of age on the absorption of $244 \mathrm{Cm}$ from the rat gastrointestinal tract (Abstract)

Radiobiologiya 13, 155 (1973) translated in AEC-tr-7430

PD 7, 995T

SEMENOV, A. I., R. M. Lyubimova-Gerasimova and G. A. Zalikin Biological effects of curium-244 in the case of intratracheal introduction

Radiobiologiya 14, 142-144 (1974) translated in AEC-tr-7548,

$181-184$ NSA 30,13012

SEMENOV, A. I. See also: 72-MOS-2, 74-MOS-2, 74-MOS-4, 74-ZAL

SEMENOV, D. I., and I. P. Tregubenko

The action of chelating compounds on tissue storage and excretion

58-SED

from the living organism of radioyttrium, radiocerium and plutonium Biokhimiya 23, 59-65 (1958) translated by Consultants Bureau, 55-60 NSA 13,1903

SEMENOV, D. I. See also: 60-TRE, 66-TRE-4

SEVASTYANOVA, Y. P. See: 72-KHA-2, 74-KHA

SEVC, J. Mechanism of the simultaneous effects of ionizing radiation and fibroplastic dust (in Czech)

Prac. Lek. 21(Mar), 49-55 (1969) NSA 23, 35640

SHABESTARI, L. See: 69-TAG, 72-TAG, 72-TAG-2, 72-TAG-3, 74-TAG 
SHALAK, N. I. See: 70-SMO, 68-TAR

SHAMOV, V. P. See: 70-BAI-5, 73-DOE, 74-DOE, 74-ERS

SHANAHAN, M. M. See: 72-EVA

SHANNON, L. V. See: 74-CHD

SHAPLEY, D.

Plutonium: Reactor proliferation threatens a nuclear black market

71-SHA

Science 172, 143-146 (1971) NSA 25, 37565

SHAPLEY, D.

Radioactive cargoes: Record good but the problems will multiply

71-SHA-2

Science 172, 1318-1322 (1971) NSA 26, 308

SHAPLEY, D.

Rocky Flats: Credibility gap widens on plutonium plant safety

71-SHA-3

Science 174, 569-571 (1971) PD $\underline{6}, 866$

SHEA, D. W. See: 70-MAE

SHEARIN, R. L., and C. R. Phillips

Contingency response for rapid evaluation of radiological pollution

71-SHE

from a space vehicle launch accident

In: Rapid Methods for Measurement of Radioactivity in the Environment

(International Atomic Energy Agency, Vienna) 757 (1971) EP 460

SHEEHAN, W. E. See: 70-ANH

SHEKHANOVA, I. A. SEe: 71-PAT

SHEPPARD, J. C. SEe: 72-CRO

SHERWOOD, R. J. See: 63-LIB

SHIBA, 0. V. See: 69-KAP

SHINN, J. H. See: 74-ANS

SHIPMAN, T. L.

Acute radiation death resulting from an accidental nuclear

61-SHT

critical excursion

J. Occup. Med. 3, 147-192 (1961) EP 471

SHIPMAN, T. L. See also: 66-LAN

SHIROTANI, T., and M. Fujita

Estimation of effective tissue thickness in the assessment of $239 \mathrm{Pu}$ in the lung

J. Nuc7. Sci. Technol. (Tokyo) 9, 165-171 (1972) NSA 26, 28517

SHIROTANI, T., and M. Fujita

A method of determination of correction factors for different body

builds in the assessment of $239 \mathrm{Pu}$ in lung

J. Nucl. Sci. Technol. (Tokyo) 10, 301-308 (1973) NSA 29, 801

SHIROTANI, T.

Empirical formula for estimating effective tissue thickness in the assessment of plutonium in lung

J. Nucl. Sci. Technol. (Tokyo) 10, 647-649 (1973) NSA 29, 27131

PD 8,1478 
SHLEIEN, B., and P. J. Magno

Plutonium concentrations in ground level air and changes in

$67-\mathrm{SHL}$ plutonium-238 to plutonium-239 ratios

Radiol. Health Data Rep. 8, 561-562 (1967)

SHLEIEN, B., M. A. Wall and D. Lutz

Estimation of radiation doses to the respiratory tract from inhalation of airborne radioactivity

Environ. Sci. Technol. 2, 438-443 (1968) NSA 22, 33821

SHLEIEN, B., J. A. Cochran and P. J. Magno

Strontium and plutonium isotopes in ground level air

Radiol. Health Data Rep. 11, 129-134 (1970) NSA 24, 33796

SHLEIEN, B., J. A. Cochran and P. J. Magno

${ }^{9} \mathrm{Sr},{ }^{89} \mathrm{Sr}, 239 \mathrm{Pu}$, and $238 \mathrm{Pu}$ concentrations in ground-level air, 1964-1969

Environ. Sci. Technol. 4, 598-602 (1970) NSA 24, 33799

SHLEIEN, B.

An evaluation of internal radiation exposure based on dose commitments from radionuclides in milk, food, and air

Hea1th Phys. 18, 267-275 (1970) NSA 24, 34340

SHLEIEN, B. See also: 67-MAG

SHREVE, J. D., Jr. Operation plumbbob. Summary report, test group 57. Preliminary report

Doc. ITR-1515, 143 p. (1958) NSA 13, 11722

SHUBIK, V. M., A. V. Fedorova and V. V. Borisova

Early changes in certain immunological indices in the case of

${ }^{239} \mathrm{Pu}$ lesion of experimental animals

Radiobiologiya $13,119-123$ (1973) translated in AEC-tr-7430,

$161-166$ NSA $2 \overline{8}, 18546$

SHUBIK, V. M. See also: 74-NEM

SHVYDKO, N. S.

Kinetics of metabolism of $239 \mathrm{Pu}$ in the liver (in Russian)

Med. Radio1. 19(10), 71-72 (1974) NSA 31, 910

SIKOV, M. R., and D. D. Mahlum

Cross-placental transfer of selected actinides in the rat

Health Phys. 14, 205-208 (1968) NSA 22, 30948

SIKOV, M. R., D. D. Mahlum, T. D. Mahony and M. F. Sullivan

Particle size and animal age as factors in evaluating hazards from ingested radionuclides

In: Gastrointestinal Radiation Injury (M. F. Sullivan, ed., Excerpta

Medica Foundation, Amsterdam) 524-535 (1968) NSA 21, 28586; 22, 49331

SIKOV, M. R., and D. D. Mahlum

Plutonium in the developing animal

Health Phys. $22,707-712$ (1972) NSA 26, 38785

SIKOV, M. R., and D. D. Mahlum

Age-dependence of $23{ }^{3} \mathrm{Pu}$ metabolism and effect in the rat

In: Radiobiology of Plutonium (B. J. Stover and W. S. S. Jee, eds.,

J. W. Press, Salt Lake City) 261-272 (1972) NSA 26, 41298

SIKOV, M. R. See also: 72-HUF, 72-KAS, 69-MAH, 69-MAH-2, 74-MAH

SILBERSTEIN, H. E. See: 50-BOY 
SILKER, W. B. See: 60-WIH

SILL, C. W.

71-SIL

Use of plutonium-236 tracer and propagation of error

In: Proceedings of Environmental Plutonium Symposium (E. B. Fowler,

et al., eds., Doc. LA-4756) 51-53 (1971)

SIMAKOV, A. V. See: 74-KHO

SIMMONS, E. L. See: 46-ABR, 46-FID, 46-JAO

SIMON-VERMOT, A. See: 70-KUN-2

SISSONS, H. A. See: 73-THU

SITKO, R. Y. See: 72-KHO, 74-KHO

SKUPINSKI, W. See: 74-LAF-2, 73-MOR-3, 72-NEO-2

SKYTTE-JENSEN, B. SeP: 70-GJO

SLOBODIEN, M. J., A. Brodsky, C. H. Ke and I. Horm

73-SLO

Removal of zinc from humans by DTPA chelation therapy

Health Phys. 24, 327-330 (1973)

SMITH, C. C. See: 62-CHR

SMITH, C. L. D. See: 64-FAB, 73-FAB

SMITH, H., T. H. Bates, B. Dymond and I. V. Chapman The effect of DTPA treatment after administration to rats of $239 \mathrm{Pu}$ (VI) in nitric acid

Int. J. Radiat. Biol. 8, 191-193 (1964) NSA 19, 5614

SMITH, H. , and T. H. Bates

Removal of radionuclides from the body

Nature 207, 799-804 (1965) NSA 19, 43700

64-SMH

SMITH, H., I. V. Chapman and C. G. Marlow

Efficiency of low level DTPA therapy in removing plutonium from mice

69-SMH

Nature 222, 676 (1969) NSA 24, 695

SMITH, H., and I. V. Chapman

$69-\mathrm{SMH}-2$

Use of citrate in mobilizing plutonium in rat

Nature 223, 642-643 (1969) NSA 24, 581

SMITH, H.

The use and limitations of DTPA to remove plutonium

65-SMH

Radiol. Prot. Bu11. 11, 15-16 (1975) NSA 32, 9222

SMITH, R. C. See: 64-PIL

SMITH, V. H.

58-SMV

Removal of internally deposited plutonium

Nature 181, 1792-1793 (1958) NSA 12, 12206

SMITH, V. H., J. E. Ballou, W. J. Clarke and R. C. Thompson

61-SMV

Effectiveness of DTPA in removing plutonium from the pig

Proc. Soc. Expt1. Biol. Med. 107, 120-123 (1961) NSA 15, 23266

SMITH, V. H.

Prevention of plutonium deposition by desferrioxamine-B

$64-S M V$

Nature 204, 899-900 (1964) NSA 19, 21839 
SMITH, V. H.

64-SMV-2

Interactions in the metabolism of $239 \mathrm{Pu}$ and ${ }^{239} \mathrm{~Np}$

In: Doc. HW-80500, 73-75 (1964) NSA 18, 41030

SMITH, V. H., H. A. Ragan, B. J. McClanahan, J. L. Beamer and

68-SMV

J. L. Palotay

The passage time of plutonium oxide in pigs

In: Gastrointestinal Radiation Injury (M. F. Sullivan, ed.,

Excerpta Medica Foundation, Amsterdam) 518-523 (1968) NSA 21, 6399

SMITH, V. H.

Therapeutic removal of internally deposited transuranium elements

$72-5 M V$

Health Phys. 22, 765-778 (1972) NSA 26, 38790

SMITH, V. H.

Metal-DTPA chelates in biological systems: A bibliography

Doc. BNWL-1657, 52 p. (1972) NSA 26, 48287

SMITH, V. H.

Biological disposition of $\mathrm{Es}\left(\mathrm{NO}_{3}\right)_{3}$ in rats after intravenous, intramuscular and subcutaneous administration

In: Proc. Third Int. Cong. Int. Radiat. Prot. Assn. (W. S. Snyder,

ed., Doc. CONF-730901-P1) Vo1. 1, 725-730 (1974) NSA 30, 27264

SMITH, V. H. See also: 69-BAI, 72-HLIF, 74-PAR

SMOLER, M. See: 68-LIN, 68-LIN-2, 69-LIN-2, 68-ROS-2

SMORODINTSEVA, G. I., S. I. Tarasov, A. F. Oreshina, N. I. Shalak and V. Z. Yaskova

Study of the uptake of air-borne ${ }^{239} \mathrm{Pu}$ by the human organism

Translation of report A-AC-82/G/L-1301, in AEC-tr-7128, 235-245

(1970) NSA 24, 12064

SMORODINTSEVA, G. I. See also: 68-TAR

SNIDER, R. S.

The skin

In: Histopathology of Irradiation from External and Internal Sources

(W. Bloom, ed., McGraw Hill, New York) 32-69 (1948)

SNYDER, R. H., W. Kisieleski, B. Lawrence and R. D. Finkle

Part 3. The metabolism of injected plutonium

In: The Toxicity and Metabolism of Plutonium in Laboratory Animals

(R. D. Finkle et al., eds., Doc. MDDC-1140) (1946) EP S2, 7

SNYDER, R. H., W. Kisielseki and R. D. Finkle

Part 4. The survival and growth of plutonium-injected animals

In: The Toxicity and Metabolism of Plutonium in Laboratory Animals

(R. D. Finkle, et a1., eds., Doc. MDDC-1140) (1946) EP S2, 10

SNYDER, R. H., B. Lawrence and R. D. Finkle

Part 5. The effect of ingested plutonium

In: The Toxicity and Metabolism of Plutonium in Laboratory Animals

(R. D. Finkle, et al., eds., Doc. MDDC-1140) (1946) EP S2, 11

SYNDER, R. H. See also: 46-FID

SNYDER, W. S.

Major sources of error in interpreting urinalysis data to estimate

the body burden of $\mathrm{Pu}^{239}$. A preliminary study.

Heal th Phys. 8, 767-772 (1962) NSA 17, 10340

48-SNI

46-SNR

46-SNR-2

$46-S N R-3$

62-SNY 
SNYDER, W. S.

The distribution of $239 \mathrm{Pu}$ in the body following exposure by inhalation

Health Phys. 10, 1035-1041 (1964) NSA 19, 3854

SNYDER, W. S.

On the estimation of a systemic body burden of plutonium

$64-$ SNY -2

Ir. Assessment of Radioactivity in Man, Vol. 2 (International

Atomic Energy Agency, Vienna) 583-588 (1964) BA 46, 105997

SNYDER, W. S., M. R. Ford and G. G. Warner

The use of excretion data to predict the systemic body burden of

68-SNY plutonium

In: Diagnosis and Treatment of Deposited Radionuclides (H. A.

Kornberg and W. D. Norwood, eds., Excerpta Medica Foundation,

Amsterdam) 279-290 (1968) NSA 23, 24641

SNYDER, W. S.

A method of interpreting excretion data which allows for statistical fluctuation of the data

In: Assessment of Radioactive Contamination in Man (International

Atomic Energy Agency, Vienna) 485-494 (1972) NSA 26, 56534

SNYDER, W. S., M. R. Ford, J. R. Muir and G. G. Warner

Fluctuations of daily excretion of plutonium and their interpretation for estimation of the body burden

In: Health Physics Operational Monitoring, Vol. 1 (C. A. Willis,

ed., Gordon and Breach, New York) 711-722 (1972) NSA 29, 29855

SNYDER, W. S. See also: 72-FIS

SOBOLEV, S. G., and V. K. Lemberg

Toxic effect of neptunium 237 on rat hepatocytes

In: Biological Effects of Radiation from External and Internal

Sources (Y. I. Moskalev and V. S. Kalistratova, eds., Meditsina,

Moscow) 236-241 (1972) translated in AEC-tr-7457, 352-358

NSA 30, 9966

SOLDAT, J. K., D. A. Baker and J. P. Corley

Applications of a general computational model for composite environmental radiation doses

In: Environmental Behavior of Radionuclides (International Atomic

Energy Agency, Vienna) NSA 28,8132

SORENSEN, E. See: 70-GJ0

SOULE, H. F.

Radiation standards and radioactive waste

In: Health Physics Aspects of Nuclear Facility Siting. Vol. 3

(P. G. Voilleque, ed., Idaho Falls, Idaho) 656-666 (1971)

NSA 25, 55253 PD ㄱ, 733

SOWBY, F. D., and D. M. Taylor

Removal of internally deposited americium by chelating agents

Nature $187,612(1960)$ NSA 14,21588

SOWBY, F. D. See also: 65-BEN, 61-TAY, 62-TAY

SPEIGHT, R. G., C. 0. Peabody and D. Ramsden

An improved chest phantom for studies of plutonium and americium in human lungs

In Assessment of Radioactivity in Man, Vol. 1 (International Atomic

Energy Agency, Vienna) 115-130 (1964) NSA 19, 30473

SPEIGHT, R. G. See also: 68-RAM 
SPENCER, H. See: 62-STE

SPIERS, F. W.

Radioisotopes in the Human Body: Physical and Biological Aspects,

Academic Press, New York, 359 p. (1968) NSA 23, 7953

SPIERS, F. W.

Biophysical basis for radiation hematology

$71-S P I$

In: Manual on Radiation Hematology (International Atomic Energy

Agency, Vienna) 45-69 (1971) NSA 25, 44805

SPITSYN, V. I. See: 74-GRO, 74-GRO-2, 74-GRO-3

SPRITZER, A. A. See: 69-BUA

STANNARD, J. N.

73-STJ

Toxicology of radionuclides

Annu. Rev. Pharmacol. 13, 325-357 (1973) NSA 28, 24878

STANNARD, J. N.

Biomedical aspects of plutonium (discovery, development, projections)

In: Uranium-Plutonium-Transplutonic Elements ( $H$. C. Hodge, J. N.

Stannard and J. B. Hursh, eds., Springer-Verlag, New York) 309-322

(1973) PD 8, 1019 EP S3, 476

STANNARD, J. N.

Plutonium in the environment

In: Uranium-Plutonium-Transplutonic Elements ( $H$. C. Hodge, J. N.

Stannard and J. B. Hursh, eds., Springer-Verlag, New York)

669-688 (1973) PD $\underline{8}, 1038$

STANNARD, J. N.

Standards for the transuranic elements (part of AEC presentation

74-STJ

at EPA Plutonium Standards Hearings, December 10-11, 1974)

In: Doc. WASH-1359, 291-305 (1974) NSA 31, 18668

STANNARD, J. N. See also; 73-HOC, 60-WIR

STARA, J. F., N. S. Nelson, R. J. Della Rosa and L. K. Bustad Comparative metabolism of radionuclides in mammals - a review

Health Phys. 20, 113-137 (1971) NSA 25, 32326

STATHER, J. W. , and S. Howden

Effect of chemical form on the clearance of 239-plutonium from the respiratory system of the rat

Health Phys. 28, 29-39 (1975) NSA 31, 23081

STATHER, J. W., S. Howden and R. F. Carter

Method for investigating the metabolism of the transportable

fraction of plutonium aerosols

Phys. Med. Biol. 20, 106-124 (1975) NSA 31, 23076

STEIN, P. C. See: 69-CAM

STEPANOV, V. S. See: 72-MOS-2, 72-ZAL-2

STEVENS, E., B. Rosoff, M. Weiner and $H$. Spencer Metabolism of the chelating agent diethylenetriamine pentaacetic acid (C 14 DTPA) in man

Proc. Soc. Expt1. Biol. Med. 111, 235-238 (1962) NSA 17, 1223

STEVENS, W., and D. L. Berliner

Serum transaminase levels in beagle dogs burdened with ${ }^{239} \mathrm{Pu}$

$71-$ STA

$75-\mathrm{STH}$

Radiat. Res. 23, 420-429 (1964) NSA. 18, 29241 
STEVENS, W., J. W. Bruenger and B. J. Stover

In vitro studies of the interactions of $\mathrm{Pu}$ IV with blood proteins

Radiat. Res. 26, 114-123 (1965) NSA 19, 43705

STEVENS, W., C. J. Nabors, Jr. and D. L. Berliner A comparison of serum transaminase levels and other serum constituents in dogs burdened with $239 \mathrm{Pu},{ }^{238} \mathrm{Th},{ }^{228} \mathrm{Ra}$, and ${ }^{226} \mathrm{Ra}$ Ann. N. Y. Acad. Sci. 145, 817-829 (1967) NSA 23, 26886

STEVENS, W., J. W. Bruenger and B. J. Stover In vivo studies on the interactions of Pu (IV) with blood constituents

Radiat. Res. 33, 490-500 (1968) NSA 22, 36204

STEVENS, W., B. J. Stover, F. W. Bruenger and G. N. Taylor Some observations on the deposition of $241 \mathrm{Am}$ in the thyroid gland of the beagle

Radiat. Res. 39, 201-206 (1969) NSA 23, 35615

STEVENS, W., and F. W. Bruenger Interaction of ${ }^{249} \mathrm{Cf}$ and $252 \mathrm{Cf}$ with constituents of dog and human blood

Health Phys. 22, 679-683 (1972) NSA 26, 38781

STEVENS, W., B. J. Stover, D. R. Atherton and F. W. Bruenger Distribution and excretion of three chemical species of $239 \mathrm{pu}$ (IV) in the beagle

Health Phys. $\underline{28}, 387-394$ (1975) NSA 32, 3828

STEVENS, W. See also: 69-BED, 69-BRU, 69-BRU-2, 71-BRU, 72-BRU, 72-NAB, 68-STB-2, 70-STB, 72-STB-2

STEWART, $K$.

The particulate material formed by the oxidation of plutonium

Progr. Nuc1. Energy, Ser. IV, 5, 535-579 (1963) NSA 18, 8565

STEWART, K., D. M. C. Thomas, J. L. Terry and R. H. Wilson A preliminary evaluation of the biological measurements on operation roller coaster

Doc. AWRE-0-29/65, 33 p. (1965) NSA 19, 36697

STEWART, $K$.

Principal characteristics of radioactive contaminants which may appear in the atmosphere

Prog. Nuc1. Energy, Ser. XII, 2, 321-360 (1969) PD $\underline{4}, 1692$

STEWART, K., and R. H. Wilson Final evaluation of the biological measurements on Operation Roller Coaster (joint U.S./U.K. field experiments)

Doc. AWRE-0-76/67, 46 p. (1969) EP S3, 220

STEWART, K. See also: 71-CAF

STONE, R. S.

Health protection activities of the plutonium project

Proc. Amer. Philosoph. Soc. 90, 11-19 (1946) BA 22, 12005

STONE, R. S. Industrial Medicine on the Plutonium Project, McGraw-Hill, New York, 511 p. (1951) EP 548

STONE, R. S. See also: 70-RIC

STORR, M. C. See: 73-DUA, 73-HOG, 74-HOG 
STOVER, B. J.

59-STB

Metabolism of radioactive isotopes which deposit mainly in the skeleton

Health Phys. 1, 373-378 (1959) NSA 13, 11570

STOVER, B. J., D. R. Atherton and N. Keller

$59-S T B-2$

Metabolism of $\mathrm{Pu}^{239}$ in adult beagle dogs

Radiat. Res. 10, 130-147 (1959) NSA 13, 9641

STOVER, B. J., D. R. Atherton and C. W. Mays

Studies of the retention and distribution of $\mathrm{Ra}^{226}, \mathrm{Pu}^{239}$,

$\operatorname{Ra}^{228}\left(\mathrm{MsTh}_{1}\right)$, $\mathrm{Th}^{228}(\mathrm{RdTh})$, and $\mathrm{Sr}^{90}$ in adult beagles

In: Some Aspects of Internal Irradiation ( $T$. F. Dougherty, et al.,

eds., Pergamon Press, New York) 7-25 (1962) NSA 17., 19884

STOVER, B. J., D. R. Atherton, F. W. Bruenger and D. S. Buster

Further studies of the metabolism of $\mathrm{Pu}^{2} 39$ in adult beagles

Health Phys. $8,589-597$ (1962) NSA 17, 10319

STOVER, B. J., and W. S. S. Jee

Some effects of long-term alpha irradiation on the composition and structure of bone

Heal th Phys. $9,267-275$ (1963) NSA 17,24929

STOVER, B. 3., D. R. Atherton, F. W. Bruenger and D. S. Buster

${ }^{2}{ }^{9} \mathrm{Pu}$ in liver, spleen, and kidneys of the beagle

Health Phys. 14, 193-197 (1968) NSA 22, 28336

STOVER, B. J., F. W. Bruenger and W. Stevens

Reaction of Pu(IV) with the iron transport system in human blood serum

Radiat. Res. $33,381-394$ (1968) NSA 22,21416

STOVER, B. J., D. R. Atherton, F. W. Bruenger and D. S. Buster Pu-239(IV) - Its distribution in the beagle

In: Delayed Effects of Bone-Seeking Radionuclides (C. W. Mays, et a)., eds., Univ. of Utah Press, Salt Lake City) 109-123 (1969) NSA 23, 38423

STOVER, B. J., F. W. Bruenger and W. Stevens

Association of americium with ferritin in the canine liver

Radiat. Res. 43, 173-186 (1970) NSA 24, 48445

STOVER, B. J., and H. Eyring

The dynamics of life. I. Death from internal irradiation by

$239 \mathrm{Pu}$ and ${ }^{226} \mathrm{Ra}$, aging, cancer, and other diseases

Proc. Nat. Acad. Sci. U.S. 66, 132-139 (1970) NSA 24, 32204

STOVER, B. J., D. R. Atherton and D. S. Buster

Protracted hepatic, splenic and renal retention of $239 \mathrm{Pu}$ in the beagle

Health Phys. 20, 369-374 (1971) NSA 25, 29451

STOVER, B. J., and W. S. S. Jee (eds.)

Radiobiology of Plutonium, J. W. Press, Salt Lake City, 583 p. (1972) NSA 26, 41253

STOVER, B. J., W. Stevens and F. W. Bruenger Chemical associations of $239 \mathrm{Pu}$ (IV) and $24 \mathrm{Am}$ (III) in blood, liver, and thyroid

In: Radiobiology of Plutonium (B. J. Stover and W. S. S. Jee, eds., J. W. Press, Salt Lake City) 129-140 (1972) NSA 26, 41293 
STOVER, B. J., D. R. Atherton and D. S. Buster

$72-\mathrm{STB}-3$

Retention of $23{ }^{9} \mathrm{Pu}$ (IV) in the beagle

In: Radiobiology of Plutonium (B. J. Stover and W. S. S. Jee, eds.,

J. W. Press, Salt Lake City) 149-169 (1972) NSA 26, 41294

STOVER, B. J., H. Eyring and D. R. Atherton

Effects of $23{ }^{9} \mathrm{Pu}$ and related radionuclides on survival of the adult beagles

In: Radiobiology of Plutonium (B. J. Stover and W. S. S. Jee, eds.,

J. W. Press, Salt Lake City) 385-407 (1972) NSA 26, 41262

STOVER, B. J.

Life shortening consequent to internal irradiation from $239 \mathrm{Pu}$

72-STB-5

Health Phys. 22, 823-827 (1972) NSA 26, 38748

STOVER, B. J., and C. N. Stover, Jr.

The Laboratory of Radiobiology at the University of Utah

In: Radiobiology of Plutonium (B. J. Stover and W. S. S. Jee,

eds., J. W. Press, Salt Lake City) 29-46 (1972)

STOVER, B. J., and D. R. Atherton

Kinetics of the skeletal retention of $239 \mathrm{Pu}(\mathrm{IV})$

$72-\mathrm{STB}-4$

Radiat. Res. $\underline{60}, 525-535$ (1974) NSA $\underline{31}, 8985$

STOVER, B. J. See also: 69-BRU, 69-BRU-2, 71-BRU, 62-COH, 62-DOT, 62-JEW, 69-MAY, 62-REH, 65-STW, 68-STW, 69-STW, 75-STW

STOVER, C. N. , Jr. See: 72-STB-6

STRELTSOVA, V. N., and Y. I. Moskalev

Radioactive isotopes as cancerogenic agents

57-STV

Med. Radiol. 22(5), 39-51 (1957) translated in JPRS 210,35-52

NSA 12,3490

STRELTSOVA, V. N.

Comparative morphology of chronic radioisotope injury

In: Distribution, Biological Effects, and Migration of Radioactive

Isotopes (A. V. Lebedinski $i$ and Y. I. Moskalev, eds., Medgiz, Moscow)

269-283 (1961) translated in AEC-tr-7512, 317-331 NSA 30, 7132

STRELTSOVA, V. N.

Pathological anatomy of $239 \mathrm{Pu}$ sickness

In: Plutonium-239: Its Distribution, Biological Effect and Accelerated

Elimination (A. V. Lebedinski ${ }^{2}$ and Y. I. Moskalev, eds., Medgiz, Moscow)

115-128 (1962) translated in FTD-TT-63-559, 173-193; al so JPRS-16900,

23-47 NSA 17,12103 EP S3, 502

STRELTSOVA, V. N., and Y. I. Moskalev

Blastomogenic Action of Ionizing Radiation, Meditsina, Moscow,

383 p. (1964) translated in AEC-tr-7595 NSA 31, 16777, 16778, 16779,16781

STRELTSOVA, V. N. See a 7so: 61-BUL-2, 69-BUL-2, 64-KRA, 61-MOS, 62-MOS, 65-MOS-2, 65-MOS-3, 67-MOS, 69-MOS-2, $69-M O S-3,73-M O S-2,74-M O S-2,74-Z A L$

STUART, B. 0., W. J. Bair and J. F. Park Interpretation of excretion data from beagle dogs after $239 \mathrm{pu}$ inhalation

In: Diagnosis and Treatment of Deposited Radionuclides ( $H$. A. Kornberg and W. D. Norwood, eds., Excerpta Medica Foundation, Amsterdam) 243-255 (1958) NSA 23, 24539 
STUART, B. 0., P. J. Dionne and W. J. Bair

70-STU

A dynamic simulation of the retention and translocation of inhaled

plutonium oxide in beagle dogs

In: Proceedings of the 11 th AEC Air Cleaning Conference, Vol. 2

(M. W. First and J. M. Morgan, Jr., eds., Doc. CONF-700816) 721-737

(1970) NSA 25, 21546

STUART, B. 0. (Panel Chmn.)

Inhalation Risks from Radioactive Contaminants, International

73-STU

Atomic Energy Agency, Vienna, 146 p. (1973) NSA 27, 24983

STUART, B. 0 .

Deposition of inhaled aerosols

Arch. Intern. Med. 131, 60-73 (1973) EP S3, 263

STUART, B. 0. See also: 64-BAI, 71-PAR

STUBER, C. E.

Transplutonium Elements. A Bibliography

Doc. TID-3317-54, 215 p. (1974) NSA 29, 17299

SLBRAHMANYAM, P. See: 74-MAD

SUDAKOV, L. V. See: 69-KAP

SUGAI, R. See: 71-TAK, 72-TAK

SUGIMURA, Y. See: 68-MIY-2, 70-MIY

SULERZHITSKII, L. D. See: 65-CHE

SULLIVAN, M. F., and R. C. Thompson

Absence of lethal radiation effects following massive oral administration of plutonium

Nature 180, 651-652 (1957) NSA 12, 1197

SULLIVAN, M. F., P. L. Hackett, L. A. George and R. C. Thompson Irradiation of the intestine by radioisotopes

Radiat. Res. 13, 343-355 (1960) NSA 14, 21225

SULLIVAN, M. F., J. L. Beamer and T. D. Mahony

Effects of intracavitary irradiation by cali fornium-252

In: Biological Effects of Neutron Irradiation, International

Atomic Energy Agency, Vienna, 299-310 (1974) NSA 30, 3664

SULLIVAN, M. F. See also: 72-BAX, 68-SIK-2, 58-THO

SURIKOV, V. V. See: 74-GRO

SURINA, A. G., and I. A. Tseveleva

Lipid metabolism in the lungs of rabbits in the normal state and

74-SUR

in the presence of plutonium lesion (Abstract)

Radiobiologiya 14, 316 (1974) translated in AEC-tr-7571, 207

SURINA, A. G. See also: 72-BUL, 68-TSE, 71-TSE

SUTER, G. M. See: 50-BOY

SUZUKI, M., E. Tanaka and 0. Matsuoka (eds.)

57-SUL

$60-$ SUL

74-SUL

Final Report of Research Project on Plutonium Hazards, April 1966-

$71-$ SUZ

March 1970, Doc. NIRS-Pu-8, 94 p. (1971) NSA 25, 57998 
SUZUKI, M., H. Okabayashi, S. Watanabe, S. Hongo and S. Ohno

Studies on the inhalation of submicron plutonium nitrate aerosols in wistar adult rats

In: Final Report of Research Project on Plutonium Hazards, April

1966-March 1970 (M. Suzuki, et al., eds., Doc. NIRS-Pu-8) 66-75

(1971) PD $\underline{6}, 1580$ EP $\underline{\text { S1 }}, 531$

SUZUKI, M. See also: 69-WAT

SWANBERG, F., Jr. Comparison of urinary excretion data from selected plutonium exposure cases at Hanford

Health Phys. 8, 761-765 (1962) NSA 17, 10339

SWANBERG, F., and R. C. Henle Excretion of $\mathrm{Pu}-239$ in a patient with a plutonium contaminated injury

J. Occup. Med. $\underline{6}(4), 174-178$ (1964) BA $\underline{45}, 84903$

SWIFT, M. N. See: 46-PAE, 49-PRO

SWINTH, K. L., B. I. Griffin and J. F. Park Whole body counting of inhaled plutonium in dogs

62-SWA

Health Phys. 13, 1223-1231 (1967) NSA 22, 8558

SWINTH, K. L.

Interpreting counting data for internally deposited plutonium

In: Diagnosis and Treatment of Deposited Radionuclides ( $H$. A.

Kornberg and W. D. Norwood, eds., Excerpta Medica Foundation,

Amsterdam) 208-221 (1968) NSA 23, 24638

SWINTH, K. L.

Photon intensities and their importance in counting transuranic materials

Doc. BNWL-1648, 24 p. (1972)

SWINTH, K. L., J. F. Park and P. J. Moldofsky

Counting plutonium in the tracheobronchial 1 ymph nodes

Health Phys. 22, 899-904 (1972) NSA 26, 38801

SWISHER, C. D. See: 72-FIS

SYCH, Z. G. See: 59-TSA, 61-TSA 
TAKIZAWA, $Y$., and R. Suga $i$

${ }^{239 P u},{ }^{90} \mathrm{Sr}$ and $137 \mathrm{Cs}$ : Concentrations in human organs of the

$71-$ TAK

Japanese

Arch. Environ. Health 23, 446-450 (1971) EP s1, 852

TAKIZAWA, Y., T. Kosaka, R. Sugai, M. Izawa and H. Watanabe Concentrations of plutonium-239, strontium-90, and cesium-137 in human organs of the northern Japanese in the last ten years (in Japanese)

Nippon Koshu Eisei Zasshi 19, 251-255 (1972) NSA 30, 3692

TAMPLIN, A. R., and T. B. Cochran Radiation Standards for Hot Particles, Natural Resources Defense Council, Washington, D.C., 52 p. (1974) NSA 29, 25892

TAMPLIN, A. R., and T. B. Cochran NRDC Comments on WASH 1535, Draft Environmental Statement, Liquid Metal Fast Breeder Reactor Program. Re: Volume II, Part 2, Section 4.6.5, Particle Lung Dose Effects, pp. 4.6-89 to 4.6-105; National Resources Defense Council, Washington, D.C. 40 p. (1974)

TAMPLIN, A. R., and T. B. Cochran The Hot Particle Issue: A Critique of WASH 1320 As It Relates to the Hot Particle Hypothesis, Natural Resources Defense Council, Washington, D.C., 47 p. (1974)

TAMPLIN, A. R., and T. B. Cochran NRDC Supplemental Submission to the Environmental Protection Agency Public Hearings on Plutonium and Transuranium Elements, Natural Resources Defense Council, Washington, D.C. (1975)

TAMURA, T. See: 59-JAD, 60-0LS

TANAKA, E. See: 71-SUZ

TANDY, R. K. See: 68-NGY

TARASENKO, N. Y., and M. A. Khodyreva Action of washing agents on skin and their effect on the absorption of radioactive substances (in Russian)

Gig. Sanit. 33(7), 107-109 (1968) PD 5, 3187

TARASOV, S. I., G. I. Smorodintseva, A. F. Oreshina, N. I. Shalak and V. Z. Yaskova

The extent of aerogenic introduction of $239 \mathrm{Pu}$ into the human body (in Russian)

Gig. Sanit. $\underline{33}(4), 34-38$ (1968) NSA 22, 40721 EP $\underline{5}, 406$

TARASOV, S. I. See also: 70-SM0

TASCHNER, J. C. See: 68-0DL-2

TASHIRO, S. Autoradiographic analysis of plutonium contamination of pig skin I. (in Japanese)

Hoken Butsuri 2, 128-133 (1967) NSA 22, 23539

TASHIRO, S., Y. Wadach and M. Muramatsu Skin contamination by radioisotopes. $V$. Pig skin contamination by $239 \mathrm{Pu}$

J. Nucl. Sci. Technol. (Tokyo) 5, 160 (1968) PD 2, 2728 
TASHIRO, S.

Autoradiographic analysis of plutonium contamination on pig skin.

2 . Change with contaminating time of the state of plutonium on

the skin, and its state after decontamination (in Japanese)

Hoken Butsuri 5(4), 187-193 (1970) NSA 26, 9526

TASHIRO, S.

Plutonium skin contamination and decontamination by decontaminants (in Japanese)

Nippon Genshiryoku Gakkaishi, 13, 2-7 (1971) NSA 25, 24143

TASHIRO, S.

Contaminative behavior of plutonium chloride on protein $\mathrm{film}$

J. Nucl. Sci. Technol. (Tokyo) 9, 344-347 (1972) NSA 26, 56513

TAUBE, M.

Physiological effects of plutonium and health physics

In: Plutonium (M. Taube, Polish Scientific Publishers, Warsaw,

translation Macmillan Co., New York) 85-102 (1964) NSA 18,

44083

TAYLOR, B. T.

A proportional counter for low-level measurement of $239 \mathrm{Pu}$ in lungs

$69-T A B$

Health Phys. 17, 59-69 (1969) NSA 23, 29203

TAYLOR, B. T. See also: 71-NED, 72-NED, 68-RUN .

TAYLOR, D. M., F. D. Sowby and N. F. Kember

The metabolism of americium and plutonium in the rat

71-TAS

Phys. Med. Biol. 6, 73-86 (1961) NSA 15, 24669

TAYLOR, D. M., and F. D. Sowby

The removal of americium and plutonium from the rat by chelating agents

Phys. Med. Biol. 7, 83-91 (1962) NSA 16, 23396

TAYLOR, D. M.

Some aspects of the comparative metabolism of plutonium and americium in rats

Heal th Phys. $8,673-677$ (1962) NSA 17, 10325

TAYLOR, D. M.

The metabolism of the transuranic elements

Brit. J. Radiol. 37, 95-100 (1964) NSA 18, 11586

TAYLOR, D. M.

Effects of desferrioxamine on the retention of actinide elements in the rat

Health Phys. 13, 135-140 (1967) NSA 21, 14669

TAYLOR, D. M.

Metabolism of plutonium in adult rabbits

Brit. J. Radiol. 42, 44-50 (1969) NSA 23, 38406

TAYLOR, D. M., and J.P. M. Bensted

Long-term biological damage from $239 \mathrm{Pu}$ and ${ }^{241} \mathrm{Am}$ in rats

$61-T A Y$

$62-T A Y$

$62-T A Y-2$

In: Delayed Effects of Bone-Seeking Radionuclides (C. W. Mays,

et a1., eds., Univ. of Utah Press, Salt Lake City) 357-370 (1969)

NSA 23, 38802

TAYLOR, D. M., and C. J. Danpure

Lysosomal uptake of actinide elements (Abstract)

69-TAY -3

Biochem. J. 115, 53P (1969) 
TAYLOR, D. M., and A. R. Chipperfield

The mode of fixation of $239 \mathrm{Pu}$ and $241 \mathrm{Am}$ in bone: A possible

explanation of their different carcinogenicity

In: Symposium Ossium (A. M. Jelliffe, eds., E. \& S. Livingstone,

London) 215-217 (1970) NSA 25, 24014

TAYLOR, D. M., and A. R. Chipperfield

Binding of transplutonium elements to proteins of bone

In: Radiation Protection Problems Relating to Transuranium Elements

(Doc. EUR-4612) 187-204 (1971) NSA 25, 37719

TAYLOR, D. M., A. R. Chipperfield and A. C. James

Effects of tetracycline on the deposition of plutonium and related elements in rat bone

Health Phys. 21, 197-204 (1971) NSA 25, 46695

TAYLOR, D. M.

Interactions between transuranium elements and the components

of cells and tissues

Health Phys. 22, 575-581 (1972) NSA 26, 38768

TAYLOR, D. M.

Cellular deposition and retention of $239 \mathrm{pu}$ in relation to the induction of neoplasms

In: Radiobiology of Plutonium (B. J. Stover and W. S. S. Jee,

eds., J.W. Press, Salt Lake City) 273-279 (1972) NSA 26, 41299

TAYLOR, D. M. , and J. D. Jones

Effects of EDTA and DTPA on DNA synthesis in kidney and intestinal mucosa of folate treated rats

Biochem. Pharmacol. 21, 3313-3315 (1972)

TAYLOR, D. M.

Chemical and physical properties of plutonium

In: Uranium-Plutonium-Transplutonic Elements (H. C. Hodge,

J. N. Stannard and J. B. Hursh, eds., Springer-Verlag, New York)

323-347 (1973) PD 8,872

TAYLOR, D. M.

Chemical and physical properties of the transplutonium elements

In: Uranium-Plutonium-Transplutonic Elements ( $H$. C. Hodge, J. N.

Stannard and J. B. Hursh, eds., Springer-Verlag, New York) 717-738

(1973) PD $\underline{8}, 130 T$

TAYLOR, D. M. See a 150: 65-BEN, 69-BEN, 70-B0C, 68-CHI, 70-CHI, 70-CHI-2, 72-CHI, 74-DAN, 71-JAM, 71-POL, 60-SOW, 68-TUR, 68-TUR-2, 73-VAU

TAYLOR, G. N., W. R. Christensen, W. S. S. Jee, C. E. Rehfeld and W. Fisher

Anatomical distribution of fractures in beagles injected with $\mathrm{Pu}^{239}$ Health Phys. 8, 609-613 (1962) BA 42, 16455

TAYLOR, G. N., C. E. Rehfeld, G. Schneebeli and H. A. Johnson

Eye changes induced by internal irradiation

In: Some Aspects of Internal Irradiation ( $T$. F. Dougherty, et al., eds., Pergamon Press, New York) 163-178 (1962) NSA 17, 19893

TAYLOR, G. N., W. R. Christensen, W. S. S. Jee, C. E. Rehfeld and

P. Petermann

Intercomparison of pathological fractures in beagles injected with $226 \mathrm{Ra},{ }^{228} \mathrm{Ra},{ }^{239} \mathrm{Pu}$ or ${ }^{90} \mathrm{Sr}$

Hea7th Phys. 12, 361-367 (1966) NSA 20, 16253 
TAYLOR, G. N., T. F. Dougherty, L. Shabestari and J. H. Dougherty

69-TAG

Soft-tissue tumors in internally irradiated beagles

In: Delayed Effects of Bone-Seeking Radionuclides (C. W. Mays, et al.,

eds., Univ. of Utah Press, Salt Lake City) 323-336 (1969)

NSA 23,38804

TAYLOR, G. N., C. E. Rehfeld, W. R. Christensen and W. S. S. Jee Influence of $226 \mathrm{Ra}$ and $239 \mathrm{Pu}$ on the dental root canal of the dog

J. Dent. Res. 48, 924-927 (1969) NSA 24,864

TAYLOR, G. N., W. S. S. Jee, N. Dockum and E. Hromyk

Microscopic distribution of $241 \mathrm{Am}$ in the beagle thyroid gland

Hea 1 th Phys. 17, 723-725 (1969) NSA 24, 11923

TAYLOR, G. N., T. F. Dougherty and W. R. Christensen

Some toxicity aspects of internally deposited $239 \mathrm{Pu}$

In: Pathology of Irradiation (C. C. Berdjis, ed., Williams and Wilkins

Co., Baltimore) 110-119 (1971) NSA 25, 29627

TAYLOR, G. N., W. S. S. Jee, C. W. Mays, R. B. Del1, J. L. Williams

and L. Shabestari

Microscopic distribution of $24{ }^{9} \mathrm{Cf}$ and ${ }^{249} \mathrm{Bk}$ in the soft tissues of beagles

Health Phys. 22, 691-693 (1972) NSA 26, 38783

TAYLOR, G. N., W. S. S. Jee, J. L. Williams and L. Shabestari Hepatic changes induced by $239 \mathrm{Pu}$

In: Radiobiology of Plutonium (B. J. Stover and W. S. S. Jee, eds.,

J. W. Press, Salt Lake City) 105-127 (1972) NSA 26, 41257

TAYLOR, G. N., W. R. Christensen, L. Shabestari and W. S. S. Jee General syndrome induced by $239 \mathrm{Pu}$ in the beagle

In: Radiobiology of Plutonium (B. J. Stover and W. S. S. Jee, eds.,

J. W. Press, Salt Lake City) 59-74 (1972) NSA 26, 41254

TAYLOR, G. N., J. L. Williams, L. Roberts, D. R. Atherton and L.

$69-T A G-2$

$69-T A G-3$

71-TAG

Shabestari

Increased toxicity of $\mathrm{Na}_{3}$ CaDTP when given by protracted administration

Health Phys. 27, 285-288 (1974) NSA 31, 3763

TAYLOR, G. N. See also: 62-CHR, 72-CHR, 62-COH, 62-JEW, 70-LOR, 72-LOR, 72-LOR-2, 69-MAY, 70-MAY, 62-REH, 69-STW, 73-THU

TAYSUM, D. H., F. G. Evans, W. M. Hammer, W. S. S. Jee, C. E. Rehfeld and L. W. Blake

Radionuclides and bone strength in beagles

In: Some Aspects of Internal Irradiation (T. F. Dougherty, et a1.,

eds., Pergamon Press, New York) 145-162 (1962) NSA 17, 19892

TEMPLE, L. A., D. H. Willard, S. Marks and W. J. Bair

Induction of lung tumors by radioactive particles

Nature 183, 408-409 (1959) NSA 13,7435

TEMPLE, L. A., S. Marks and W. J. Bair

Tumours in mice after pulmonary deposition of radioactive particles

$72-T A G-2$

72-TAG

\author{
72-TAG-2
}

$72-T A G-3$

74-TAG

Int. J. Radiat. Biol. 2, 143-156 (1960) NSA 14, 16551

TEMPLE, L. A. See also: 61-BAI, 62-BAI-2, 53-J0F, 54-WAG 
TERES 1, J. D., and C. L. Newcombe An evaluation of hazards from immersion of plutonium in the marine

68-TER environment

In: Proceedings of the 1st International Congress of Radiation Protection. Part 1. (W. S. Snyder, et a 1., eds., Pergamon Press, New York) 673-680 (1968) NSA 23, 12107

TERNOVSKII, A. I., R. A. Erokhin, N. A. Koshurnikova and M. G. Poplyko Evaluation of the uniformity of irradiation of the lungs in the case of chronic inhalation of plutonium-239 citrate (Abstract) Radiobiologiya 14,635 (1974) translated in AEC-tr-7602, 216

TERRY, J. L. See: 62-BIJS, 58-CLA, 65-STK, 65-WIR, 67-WIR, 68-WIR

TESTA, C., G. Masi and V. Marchionni

Plutonium bioassay laboratory at the Casaccia Nuclear Centre

In: Radiation Protection Problems Relating to Transuranium Elements

(Doc. EUR-4612) 421-435 (1971) NSA 25, 37820

TESTA, C Indirect methods used at. CNEN for the evaluation of internal contamination

In: Assessment of Radioactive Contamination in Man (International

Atomic Energy Agency, Vienna) 405-421 (1972) NSA 26, 55768

TESTA, C., and A. Delle Site

Study of a case which involved a wound contaminated with insoluble $\mathrm{Pu}$ and $241 \mathrm{Am}$

In: Health Physics Problems of Internal Contamination (E. Bujdoso, ed., Akademiai Kiado, Budapest) 593-599 (1973) NSA 28, 30321

THILO, G. See: 52-ASL

THOMAS, C. W., and R. W. Perkins Airborne radionuclides associated with normal and anomalous reactor operations

In: Assessment of Airborne Radioactivity (International Atomic

Energy Agency, Vienna) 105-118 (1967) PD 2, 1687

THOMAS, D. M. C. See: 65-STK

THOMAS, J. M. SEe: 72-CRD

THOMAS, R. G.

Influence of aerosol properties upon gross distribution and excretion Health Phys. 10,1013-1028 (1964) NSA 19, 3852

THOMAS, R. G.

Transport of relatively insoluble materials from lung to lymph nodes Health Phys. 14, 111-117 (1968) NSA 22, 21507

THOMAS, R. G.

Estimation of $241 \mathrm{Am}$ body burdens by analysis of whole-body scanning, excreta and body weight data Health Phys. 19,751-755 (1970) NSA 25, 16009

THOMAS, R. G.

Interspecies model for retention of inhaled particles

In: Assessment of Airborne Particles. Fundamentals, Applications and Implications to Inhalation Toxicity ( $T$. T. Mercer, ed., Charles $C$. Thomas, Publisher, Springfield, Illinois) 405-420 (1972) NSA 26 , 36463 
THOMAS, R. G., R. 0. Mcclellan, R. L. Thomas, T. L. Chiffelle, C. H.

72-THR-2

Hobbs, R. K. Jones, J. L. Mauderly and J. A. Pickrell

Metabolism, dosimetry and biological effects of inhaled ${ }^{241} \mathrm{Am}$ in beagle dogs

Hea]th Phys. 22 , 863-871 (1972) NSA 26, 38749

THOMAS, R. G.

Tracheobronchial $1 \mathrm{ymph}$ node involvement following inhalation of alpha emitters

In: Radiobiology of Plutonium (B. J. Stover and W. S. S. Jee, eds.,

1. W. Press, Salt Lake City) 231-241 (1972) NSA 26, 41297

THOMAS, R. G. See a1so: 62-CHW, 72-MCR-2, 68-0DL-2, 60-WIR

THOMAS, R. L. See: 72-THR-2

THOMAS, W. A., and D. G. Jacobs

Curium behavior in plants and soil

Soi1 Sci. 108, 305-307 (1969) BA 51, 52874

THOMPSON, J. C., Jr. See: 62-MIH

THOMPSON, J. L. See: 67-FIS

THOMPSON, R. C.

Research at Hanford on therapy for internally deposited plutonium In: Therapy of Radioelement Poisoning (M. W. Rosenthal, ed., Doc.

ANL-5584) 114-122 (1956) EP S2, 200

THOMPSON, R. C., H. M. Parker and H. A. Kornberg

Validity of maximum permissible standards for internal exposure

Proc. Int. Conf. Peaceful Uses At. Energy 13, 201-204 (1956)

THOMPSON, R. C., W. J. Bair, S. Marks and M. F. Sullivan

Evaluation of internal exposure hazards for several radioisotopes encountered in reactor operation

In: Proceedings of the Second United Nations International Conference

on the Peaceful Uses of Atomic Energy, Vol. 23, Experience on

Radiological Protection (United Nations, Geneva) 283-289 (1958)

NSA 12,14512

THOMPSON, R. C.

Vertebrate radiobiology: Metabolism of internal emitters

Annu. Rev. Nuc1. Sci. 10, 531-560 (1960) NSA 15, 4904

THOMPSON, R. C. (ed.)

Proceedings of the Hanford Symposium on the Biology of the

Transuranic Elements

Health Phys. $\underline{8}, 561-784$ (1962) NSA $\underline{17}, 10316$

THOMPSON, R. C.

SNPO and SNAP biological studies. Summary technical report

Doc. BNWL $-182,17$ p. (1966) NSA 20, 14785

THOMPSON, R. C.

Biological factors

In: Plutonium Handbook; A Guide to the Technology, Vol. 2 (0. J. Wick, ed., Gordon and Breach, New York) 785-829 (1967) NSA 22, 8490

THOMPSON, R. C.

Properties of radionuclides in tissues: A new look at some old problems

In: Diagnosis and Treatment of Deposited Radionuclides (H. A. Kornberg and W. D. Norwood, eds., Excerpta Medica Foundation, Amsterdam) 39-44 (1968) NSA 22, 2479 
THOMPSON, R. C., and W. J. Bair (eds.)

72-THO

Proceedings of the Hanford Symposium on the Biological Implications of the Transuranium Elements

Health Phys. 22, 533-954 (1972) NSA 26, 38766

THOMPSON, R. C., J. F. Park and W. J. Bair Some speculative extensions to man of animal risk data on plutonium

72-THO-2

In: Radiobiology of Plutonium (B. J. Stover and W. S. S. Jee, eds.,

J.W. Press, Salt Lake City) 221-230 (1972) NSA 26, 41260

THOMPSON, R. C.

Biology of the transuranium elements. A bibliography

73-THO

Doc. BNWL-1782 (1973) NSA 28, 27669

THOMPSON, R. C. Effects of plutonium in animals

In: Plutonium Information Meeting for an Ad Hoc Subcommittee of the

Advisory Committee on Reactor Safeguards, Doc. CONF-740115, 56-63

(1974) NSA 31,14413

THOMPSON, R. C.

Implications with respect to protection criteria (part of AEC presentation at EPA Plutonium Standards Hearings, December 10-11, 1974)

In: Doc. WASH-1359, 271-289 (1974) NSA 31, 16862

THOMPSON, R. C. See also: 74-BAI, 62-BAL, 62-BAL-2, 67-BAL, 72-HUF, 56-0AK, 70-SAN-3, 61-SMV, 57-SUL, 60-SUL, 53-WEK-2, 55-WEK, 56-WEK

THOMPSON, S. ᄃ. See: 68-NGY

THURMAN, G. B.

Growth dynamics of osteosarcomas in beagles (Thesis, Univ. of Utah)

71-THU

Doc. C00-119-243, 127 p. (1971) NSA 25, 29621

THURMAN, G. B., C. W. Mays, G. N. Taylor, A. T. Keane and H. A. Sissons Skeletal location of radiation-induced and naturally occurring osteosarcomas in man and dog

Cancer Res. 33, 1604-1607 (1973) NSA 29, 8067 EP $\underline{5}, 234$

TIEDEMAN, D. V. See: 50-BOY-2

TIETJEN, G. L. See: 69-MOW

TIMOFEEV, G. A. See: 69-KAP

TISSEN, M. Y. See: 71-OSA-2, 73-0SA

TODD, R., and R. Logan

$237 \mathrm{pu}$ labelling: A new technique for plutonium metabolic studies

$66-T O D$

in animals

Int. J. Appl. Radiat. Isotop. 17, 253-255 (1966) NSA 20, 18221

TODD, R., and R. Logan

$237 \mathrm{Pu}$ for metabolic studies: Its preparation and use

Int. J. App1. Radiat. Isotop. 19, 141-145 (1968) NSA 22, 28385

TODD, R. See also: 68-LOG

TOKARSKAYA, Z. B. See: 63-ELK

TOLOCHKOVA, N. M. See: 67-BUL 
TOMBROPOULOS, E. G., W. J. Bair and J. F. Park

Effect of diethylenetriaminepentaacetic acid and polypropylenogly-

colethylene oxide polymer on excretion of inhaled $239 \mathrm{PuO}_{2}$ in dogs

Nature 198, 703-704 (1963) NSA 17, 23055

TOMBROPOULOS, E. G.

Review of therapeutic procedures for removal of inhaled radioactive materials

Health Phys. 10, 1251-1257 (1964) NSA 19, 3866

TOMBROPOUL0S, E. G. See a1so: 63-BAI-2

TOTTER, J. R.

Biological research with plutonium 1944-1984

In: Radiobiology of Plutonium (B. J. Stover and W. S. S. Jee, eds.,

J. W. Press, Salt Lake City) 23-27 (1972) PD 6, 2787

TREGUBENKO, I. P., and D. I. Semenov

The effect of complexones on the behavior of metals and radioactive agents in the body. III. Phosphates (in Russian)

Tr. Inst. Biol., Akad. Nauk SSSR, Ural. Filial, 12, 5-22 (1960)

NSA 16,32706

TREGUBENKO, I. P.

Inhalation of plutonium by rats

Tr. Inst. Biol., Akad. Nauk SSSR, Ural. Filial, No. 46, 89-97 (1966)

translated in AEC-tr-7169, 124-136 NSA 22, 8477; 25, 6611

TREGUBENKO, I. P.

Fate of plutonium in a pregnant organism and its effect on the viability of the fetus

Tr. Inst. Biol., Akad. Nauk SSSR, Ural. Filial, No. 46, 125-130 (1966)

translated in AEC-tr-7169, 171-179 NSA 22, 8478; 25, 6614

TREGUBENKO, I. P.

Experiments on the effect of certain materials on the behavior of plutonium in an organism

Tr. Inst. Biol., Akad. Nauk SSSR, Ural. Filial, No. 46, 143-146 (1966)

translated in AEC-tr-7169, 199-204 NSA 22,8480;25,6616

TREGUBENKO, I. P., and D. I. SemeneV

Combined effects of complex forming substances and diuretics on

the behavior of radio-emitters in the organism

Tr. Inst. Biol., Akad. Nauk SSSR, Ural. Filial, No. 46, 147-149 (1966)

translated in AEC-tr-7169, 205-209 NSA 22, 12787; 25, 6617

TREGUBENKO, I. P. See also: 58-SED

TRIFONOV, V. I. See: 74-KAV, 72-ZAL-3, 74-ZAL

TRNOVEC, T., and A. Pleskova

Mechanisms of hepatic uptake of hepatotropic radionuclides

Prac. Lek. 23(5), 175-181 (1971) translated in BNWL-tr-71 NSA 25,

49095 EP $\underline{5}, 235$

$66-\mathrm{TRE}$

60-TRE

$66-T R E-2$

TROFIMOV, V. I. See: 73-MOS

TRUHAUT, R., C. Boudene and M. Lutz

Research in the complexon series. I. Detoxicant capacity of

$66-$ TRE -3

Ca-DTPA in experimental chronic plutonium poisoning in rats (in French)

Ann. Biol. Clin. (Paris) 24, 419-426 (1966) NSA 21, 18007 
TRUHAUT, R., C. Boudene and M. Lutz Research in the complexon series. II. Influence of the repeated intravenous administration of Ca-DTPA on the elimination of trace elements in rats (in French)

Ann. Biol. Clin. (Paris) 24, 427-434 (1966) NSA 21, 18008

TRUHAUT, R., C. Boudene, M. Lutz and H. Metivier

On the comparative efficacy of desferrioxamine and DTPA as agents for the elimination of plutonium in poisoned rats (in French)

Arch. Mal. Prof. Med. Trav. Secur. Sociale 27, 669-676 (1966)

NSA 23, 9893

TRUJILLO, T. T. See: 54-FOR-2, 55-FOR

TSARAPKIN, S. R., and Z. G. Sych

The effect of $239 \mathrm{Pu}$ and $89,90 \mathrm{Sr}$ on the bone marrow of the white rat

Med. Radiol. 4(6), 75-77 (1959) translated in JPRS-2773, 110-113

NSA 15,$66 ; \overline{13}, 16708$

TSARAPKIN, S. R., and Z. G. Sych

Effects of plutonium-239 and strontium-89, 90 on albino rat marrow

In: Distribution, Biological Effects, and Migration of Radioactive

Isotopes (A. V. Lebedinskii and Y. I. Moskalev, eds., Medgiz, Moscow)

284-289 (1961) translated in AEC-tr-7512, 332-338 NSA 30, 7133

TSEVELEVA, I, A.

The plutonium content in the protein fraction of rat tubular bones

Biokhimiya 25, 636-639 (1960) translated by Consultants Bureau, 487-489

NSA $15,127 \overline{01}$

TSEVELEVA, I. A.

Plutonium content in protein fractions in bone

In: Plutonium-239: Its Distribution, Biological Effect and Accelerated

El imination (A. V. Lebedinskii and Y. I. Moskalev, eds., Medgiz, Moscow)

52-55 (1962) translated in FTD-TT-63-559, 70-76 NSA 17, 30276

TSEVELEVA, I. A., and R. E. Libinzon

Influence of $239 \mathrm{Pu}$ on metabolism of free ribonucleotides in rabbit liver

Radiobiologiya 6, 219-223 (1966) translated in AEC-tr-6771, 81-87

NSA 21,6424

TSEVELEVA, I. A., R. E. Libinzon, G. S. Mushkacheva, T. N. Rysina and $A$. G. Surina

Biochemical changes in the lungs of rabbits after inhalation of plutonium

Radiobiologiya 8, 535-541 (1968) translated in AEC-tr-7014, 68-76

NSA 23, 4869

TSEVELEVA, I. A., and R. A. Erokhin

Behavior of $241 \mathrm{Am}$ in the body of rats under intraperitoneal and intratracheal administration

In: Radioactive Isotopes and the Body (Y. I. Moskalev, ed., Meditsina,

Moscow) (1969) translated in AEC-tr-7195, 161-167 NSA 25, 23966

TSEVELEVA, I. A.

Metabolism of glucosamineglycans (acid mucopolysaccharides) in

rabbits lungs after plutonium poisoning (in Russian)

vop. Med. Khim. 16,399-405 (1970) NSA 24, 51051

TSEVELEVA, I. A., G. S. Mushkacheva, T. N. Rysina, A. G. Surina and

59-TSA

$67-T S A$

60-TSE

62-TSE

66-TSE

V. V. Kreslov

Mechanism of development of plutonium pneumosclerosis

In: Remote Aftereffects of Radiation Damage (Y. I. Moskalev, ed.,

Atomizdat, Moscow) 340-350 (1971) translated in AEC-tr-7387,

$371-380$.PD 7, 2072 
TSEVELEVA, I. A.

74-TSE

Collagen biosynthesis in rat lungs in radiation injury (in Russian)

Vop. Med. Khim. 20, 640-643 (1974) NSA 31, 23059

TSEVELEVA, I. A. See also: 62-BEL-2, 72-BUL, 61-ELK, 62-ELK, 72-KOS, 73-KOS, 69-MUS, 62-RYS-2, 7I-RYS, 74-SUR

TSUJI, T. See: 71-SAK

TULIKOURA, J., T. Jaakkola and J. K. Miettinen

Plutonium in lichen in Finland during 1960-1973

74-TUL

In: Radioactive Foodchains in the Subarctic Environment (J. K.

Miettinen, ed., Helsinki Univ.) Paper 62 (1974) NSA 30, 15446

TURNER, G. A., and D. M. Taylor

Binding of plutonium to serum proteins in vitro

Radiat. Res. 36, 22-30 (1968) NSA 22, 51466

TURNER, G. A., and D. M. Taylor

The transport of plutonium, americium, and curium in the blood of rats

Phys. Med. Biol. 13, 535-546 (1968) NSA 23, 2748

TWENTE, J. A., and W. S. S, Jee

The determination of localized concentration of $\mathrm{Pu}^{239}$ in bone

Health Phys. 5, 142-148 (1961) NSA 15, 23257

TWENTE, J. A. See also: 62-JEW-3

TYLER, G. R.

Self-absorption of x-rays by plutonium particles with special reference to plutonium in wound monitoring

Health Phys. 12, 509-519 (1966) NSA 20, 20951

66-TYL 
ULLBERG, S., A. Nelson, H. Kristoffersson and A. Engstrom

$62-$ LILB

Distribution of plutonium in mice - An autoradiographic study

Acta Radiol. 58, 459-471 (1962) NSA 17, 10260

UNITED Nations Scientific Committee on the Effects of Atomic Radiation

72-UNS Ionizing Radiation: Levels and Effects, Vols. I and II, United

Nations, New York, 200 p., 254 p. (1972)

UNITED States Atomic Energy Commission - Division of Operational Safety Operational accidents and radiation exposure experience within the USAEC 1943-1970

Doc. WASH 1192, 126 p. (1971) NSA 26, 9558

UNITED States Atomic Energy Commission - Nevada Operations Office Enewetak Radiological Survey

Doc. NVO-140; Vol. 1, 747 p.; Vol. 2, 617 p.; Vol. 3, 687 p. (1973)

NSA 30, 24007, 24008, 24009

UNITED States Atomic Energy Commission, Advisory Committee on Reactor Safeguards

Plutonium Information Meeting for an Ad Hoc Subcommittee of the Advisory Committee on Reactor Safeguards

Doc. CONF-740115, 96 p. (1974)

UNITED States Atomic Energy Cominission Plutonium and Other Transuranium Elements: Sources, Environmental Distribution and Biomedical Effects

Doc. WASH-1359, 327 p. (1974) NSA 31, 16524

UNITED States Environmental Protection Agency

Environmental Radiation Dose Commitment: An Application to the Nuclear Power Industry

Doc. EPA-520/4-73-002, 88 p. (1974) NSA 30,3175

UNITED States Environmental Protection Agency Proceedings of Public Hearings: Plutonium and Other Transuranium Elements. Vol. 1. Proceedings of Hearings in Washington, D.C., December 10-11, 1974

Doc. ORP/CSD-75-1, 863 p. (1975) NSA 32, 22273

UNRLIH, C. M.

Radiation hazards with recycle plutonium fuels

Nucl. Safety $\underline{5}, 378-382$ (1964) NSA 18,43854

$64-U N R$

USHAKOVA, A. P. See: 74-LIK

USHAKOVA, V. F. See: 63-FRA 
VAANE, J. P.

Hazards connected with the handling of transuranium elements and

69-VAN methods used for the protection of personnel

Actinides Rev. 1, 337-370 (1969) NSA 24, 2436 PD $\underline{3}, 470 T$

VAANE, J. P., and E. M. M. DeRas

Analysis of a case of internal contamination with $242 \mathrm{Cm}$

$71-$ VAN

Health Phys. 21, 821-826 (1971) NSA 26, 9531

VAANE, J. P., E. M. M. DeRas and C. Von Brandenstein

Particle size distributions of some transuranium element compounds and the deposition in the respiratory tract after inhalation

In: Radiation Protection Problems Relating to Transuranium Elements

(Doc. EUR-4612) 383-401 (1971) NSA 25, 37799

VALBERG, P. A. See: 74-BRJ

VALENTINE, A. M. Capabilities for control of plutonium in processing

In: Plutonium Information Meeting for an Ad Hoc Subcommittee of the

Advisory Committee on Reactor Safeguards, Doc. CONF-740115, 72-78

(1974) NSA 31, 14342

VAN DER STRICHT, E. See: 68-DEB

VAN MIDDLESWORTH, L.

Study of plutonium metabolism in bone

Doc. MDDC-1022, 100 p. (n.d.) (decl. 1947) ADD 1, 1022

VANDERBEEK, J. W.

Plutonium in puncture wounds

Doc. HW-66172, 18 p. (1960) NSA 29, 18659 PD 8, 2499

VAUGHAN, J. M.

56-VAU

The effects of radiation on bone

In: The Biochemistry and Physiology of Bone (G. H. Bourne, ed., Academic

Press, New York) 729-765 (1956)

VAUGHAN, J. M.

Bone disease induced by radiation

Int. Rev. Expt1. Pathol. 1, 243-369 (1962) NSA 18, 21870

VAUGHAN, J.

Non-uniformity of radiation dose in space with special reference to radiological protection

Int. J. Radiat. Biol. 9, 513-543 (1965) NSA 20, 8524

VAUGHAN, J., B. Bleaney and M. Williamson Uptake of plutonium in bone marrow: A possible leukaemic risk

Brit. J. Haematol. 13, 492-502 (1967) NSA 22, 10736

VAUGHAN, J.

Haematological consequences of radioisotope incorporation with particular reference to plutonium, thorium, radium, iron, and gold

In: Manual on Radiation Hematology (International Atomic Energy

Agency, Vienna) 215-242 (1971) NSA 25, 44754

VAUGHAN, J.

Bone surfaces: What are they?

62-VAU

In: Radiobiology of Plutonium (B. J. Stover and W. S. S. Jee, eds.,

J. W. Press, Salt Lake City) 323-332 (1972) NSA 26, 41301

65-VAU

67-VAU

71-VAU

72-VAU 
VAUGHAN, J., B. Bleaney and D. M. Taylor

73-VAU

Distribution, excretion and effects of plutonium as a bone-seeker

In: Uranium-Plutonium-Transplutonic Elements (H. C. Hodge, J. N.

Stannard and J. B. Hursh, eds., Springer-Verlag, New York) 349-502

(1973) PD $\underline{8}, 1020$

VAUGHAN, J. M.

Effects of Irradiation on the Skeleton, Oxford University Press,

73-VAU-2

New York, 308 p. (1973) NSA 30, 9879

VAUGHAN, J. See a150: 71-BLE, 62-HER, 67-WIM

VERNON, P. B.

Health hazards associated with the fabrication of plutonium-

aluminum fuel elements

Health Phys. 12, 1109-1113 NSA 20, 39153

VERNON, P. B., R. M. Hall and G. A. Poda

Monitoring, decontamination and bio-assay of a plutonium-contaminated injury

Health Phys. 12, 1539-1543 (1966) NSA 21, 14650

VIER, M. See: 53-FOR

VISHWAKARMA, R. R. See: 74-MAD

VOELZ, G. L. See: 73-HEM, 73-HEM-2, 74-HEM

VOGT, G., and B. Kawin

Localization of radioelements in rat ovary

58-VOG

Doc. HW-53500, 120-125 (1958) EP S2, 246

VOGT, G. See also: 58-D0C, 59-D0C, 62-PAR

VOLCHOK, H. L.

Resuspension of plutonium-239 in the vicinity of Rocky Flats

In: Proceedings of Environmental Plutonium Symposium (E. G. Fowler,

et a1., eds., Doc. LA-4756) 99-103 (1971) PD $\underline{6}, 2211$

VOLCHOK, H. L., R. H. Knuth and M. T. Kleinman

Respirable fraction of plutonium at Rocky Flats

$66-V E R$

Health Phys. 23, 395-396 (1972) NSA 26, 50585

VOLCHOK, H. L.

Transuranic elements in the marine environment (part of AEC

presentation at EPA Plutonium Standards Hearings, December

$10-11,1974)$

In: Doc. WASH-1359, 155-168 (1974) NSA 31, 16541

VOLCHOK, H. L. See also: 72-HAR, 72-HAR-2, 69-KLE, 73-HAR

VOLF, V.

Present position and problems of chelation therapy

In: Radiation Protection Problems Relating to Transuranium Elements

(Doc. EUR-4612) 223-248 (1971) NSA 25, 37780

VOLF, V., E. Polig and A. Seidel

Biological experiments with transuranium elements (in German)

$71-\mathrm{VOH}$

KFK Nachr. 4 (2), 20-23 (1972) NSA 26, 59144

VOLF, $V$.

Combined effect of DTPA and citrate on an intramuscular ${ }^{239} \mathrm{Pu}$

$72-\mathrm{VOH}-2$

deposit in rats

Heal th Phys. $\underline{27}, 152-153$ (1974) NSA $\underline{30}, 16052$

71-VOL

72-VOL

74-VOL 
VOLF, V.

$74-V O L-2$

Experimental background for prompt treatment with DTPA of ${ }^{239} \mathrm{Pu}-$ contaminated wounds

Health Phys. 27, 273-277 (1974) NSA 31, 3765

VOLF, V., and A. Seidel

Decorporation of $239 \mathrm{Pu}$ and $241 \mathrm{Am}$ in the rat and hamster by $\mathrm{Zn}$-DTPA

$74-$ VOL -3

Radiat. Res. 59, 638-644 (1974) NSA 30, 29813

VOLF, V.

The effect of combinations of chelating agents on the translocation

75-VOL

of intramuscularly deposited $239 \mathrm{Pu}$ nitrate in the rat

Health Phys. 29, 61-68 (1975) NSA 32, 28321

VOLF, V. See also: 71-SEI, 72-SEI, 72-SEI-3

VON BRANDENSTEIN, C. See: 71-VAN-2

VORONINA, T. F. See: 71-GNE-2 
WACHHOLZ, B. W. See; 74-BAI-3

WADACH, Y. See: 68-TAS

WAGER, R. W., and L. A. Temple

Comparison of CaEDTA with zirconium citrate in promoting excretion

54-WAG of plutonium from the dog

In: Doc. HW-30437, 114-121 (1954)

WAITE, D. A.

Production and human inhalation of plutonium labeled particles in the submicron range

Thesis, Oklahoma State Univ., Stillwater, 104 p. (1972) Univ.

Microfilms Order No. 73-15,271 NSA 28, 18568

WAITE, D. A. See also: 72-RAM, 73-SEL

WALD, N., R. Wechsler, A. Brodsky and S. Yaniv Problems in independent medical management of plutonium-americium contaminated patients

In: Diagnosis and Treatment of Deposited Radionuclides ( $H$. A. Kornberg and W. D. Norwood, eds., Excerpta Medica Foundation, Amsterdam) 575-586 (1968) NSA 23, 24656

WALD, N. See also: 68-BRo, 72-BR0

WALKE, W. P. See: 72-J0Y

WALKER, R, L. See: 67-FIS

WALL, M. A. See: 68-SHL

WALLACE, A., V. Q. Hale and C. B. Joven DTPA and $\mathrm{pH}$ effects on leaf uptake of ${ }^{59} \mathrm{Fe},{ }^{65} \mathrm{Zn},{ }^{137} \mathrm{Cs},{ }^{241} \mathrm{Am}$ and $210 \mathrm{pb}$

J. Amer. Soc. Hort. Sci. 94, 684-686 (1969) NSA 24, 23102

WALLACE, A.

Effects of micronutrient and DTPA applications on ${ }^{241} \mathrm{Am}$ and micronutrient contents of PI54619-5-1 soybeans grown in calcareous Hacienda loam soil

In: Regulation of the Micronutrient Status of Plants by Chelating Agents and Other Factors (A. Wallace, University of California, Los Angeles) 8-9 (1971) EP 5, 246

WALLACE, A.

Retranslocation of ${ }^{241} \mathrm{Am}$ in bush beans

In: Regulation of the Micronutrient Status of Plants by Chelating

Agents and Other Factors (A. Wallace, University of California, Los Angeles) 96-97 (1971) EP 5, 245

WALLACE, A.

Transport of some heavy metals into the xylem exudate of tobacco In: Regulation of the Micronutrient Status of Plants by Chelating Agents and 0ther Factors (A. Wallace, University of California, Los Angeles) 140-142 (1971)

WALLACE, A.

Effect of citrus rootstock and chelating agent on specific activity of iron and zinc in shoots of grafted plants and on ${ }^{59} \mathrm{Fe},{ }^{65} \mathrm{Zn},{ }^{210} \mathrm{~Pb}$, and $241 \mathrm{Am}$ contents in the shoots

In: Regulation of the Micronutrient Status of Plants by Chelating Agents and 0ther Factors (A. Wallace, University of California, Los Angeles) 168-172 (1971) EP 5, 244

69-WAC

71-WAC

$71-W A C-2$

$71-W A C-3$

$71-W A C-4$ 
WALLACE, A.

Increased uptake of ${ }^{241} \mathrm{Am}$ by plants caused by the chelating agent

72-WAC DTPA

Health Phys. 22, 559-562 (1972) NSA 26, 38804

WALLACE, A.

Effect of soil pH and chelating agent (DTPA) on uptake by and

72-WAC-2

distribution of $241 \mathrm{Am}$ in plant parts of bush beans

Radiat. Bot. $12,433-435$ (1972) NSA 27, 151.29

WALLACE, A., and E. M. Romney

Feasibility and alternate procedures for decontamination and post treatment management of Pu-contaminated areas in Nevada

Doc. UCLA 12-973, 90 p. (1974) NSA 31,3390

WALLACE, A. See also: 70-HAQ, 73-ROM, 75-ROM

WALLACE, P. See: 53-HAM

WARD, E. E.

Uptake of plutonium by the lobster Homarus vulgaris

Nature 209, 625-626 (1966) NSA 20, 18227

WARD, F. A., and J. C. Lynn

Effect of the irradiation of nuclear fuel on the internal dosimetry of plutonium

In: Radiation Protection Problems Relating to Transuranium Elements

(Doc. EUR-4612) 363-382 (1971) NSA 25, 37818

WARD, F. A. See also: 73-HOE, 74-SCG

WARNER, G. G. See: 68-SNY, 72-SNY-2

WARREN, S. SEe: 73-NOM

WASHBURN, L. C. See: 73-HAW

WATANABE, H. See: 73-OKA, 72-TAK

WATANABE, S., and M. Suzuki

Plutonium aerosol inhalation apparatus (in Japanese)

Nippon Genshiryoku Gakkaishi 11, 562-566 (1969) NSA 23, 50004

WATANABE, S. See also: 71-SUZ-2

WATSON, E. C. See: 73-SEL

WATSON, E. E. See: 67-CLO

WATTERS, R. L., and J. E. Johnson

Skin absorption of plutonium in DMSO solution

70-WAR

Health Phys. 19, 318-320 (1970) NSA 24, 50693

WATTERS, R. L., and J. L. Lebel

Progress in the beagle studies at Colorado State University

66-WAE

71-WAF

Health Phys. 22, 811-814 (1972) NSA 26, 38794

WATTERS, R. L., and L. J. Johnson

Movement of plutonium and americium from wound sites

In: Health Physics Operational Monitoring, Vol. 1 (C. A. Willis, ed., Gordon and Breach, New York) 723-730 (1972) NSA 29, 29868

WATTERS, R. L. See also: 72-BIS, 75-DAG, 75-DAG-2, 72-GOM, 74-GOM, 70-JOL, 70-J0L-2, 72-JOL-2, 70-LEJ, 71-PAI 
WATTS, L.

Clearance rates of insoluble plutonium-239 compounds from the lung

75-WAS

Health Phys. 29, 53-59 (1975) NSA 32, 28317

WEBB, G. A. M., and F. Morley

A model for the evaluation of the deep ocean disposal of radioactive

74-WEB wastes

In: Proc. Third Int. Cong. Int. Radiat. Prot. Assn. (W. S. Snyder,

ed., Doc. CONF-730901-P1) Vol. 1, 313-318 (1974)

WECHSLER, R. See: 68-BRO, 68-WAL

WEEKS, M. H., and W. D. Oakley

Absorption of plutonium through the living skin of the rat: Rates of penetration and methods of skin decontamination

In: Doc. HW-28636, 85-91 (1953) EP S2, 149

WEEKS, M. H., W. D. Oakley, J. Katz and R. C. Thompson Absorption of plutonium through the skin of the rat - Rates of penetration and methods for skin decontamination

Doc. HW-30232, 20 p. (1953) EP S2, 137

WEEKS, M. H., and W. D. Oakley

Absorption of plutonium through the living skin of the rat

In: Doc. HW-30437, 102-105 (1954) EP 6, 151

WEEKS, M. H., W. D. Oakley and R. C. Thompson Influence of plutonium concentration on effectiveness of therapeutic agents

Radiat. Res. 2, 237-239 (1955) NSA $\underline{8}, 6078$

WEEKS, M. H., and W. D. Oakley

Percutaneous absorption of plutonium solutions in rats

In: Doc. HW-35917, 56-63 (1955) EP S2, 177

WEEKS, M. H., J. Katz, W. D. Oakley, J. E. Ballou, L. A. George,

L. K. Bustad, R. C. Thompson and H. A. Kornberg

Further studies on the gastrointestinal absorption of plutonium

Radiat. Res. 4, 339-347 (1956) NSA 10, 7458 EP S3, 510

WEEKS, M. H. See also: 55-KAT-2

WEGST, W. F., Jr.

Safety analysis report for alpha sources used on surveyor spacecraft

71-WEG

Health Phys. 21, 301-308 (1971) NSA 25, 47030

WEHNER, A. P.

Negatively charged aerosols. Effects on pulmonary clearance of inhaled $239 \mathrm{PuO}_{2}$ in rats

Chest $60(5), 468-471$ (1971) NSA 26, 33824

WEHNER, A. P. See also: 71-PAR

WEI, C. T. See: 72-ARN

WEIMER, W. C. See: 74-EMR

WEINER, M. See: 62-STE

WELANDER, A. D.

Distribution of radionuclides in the environment of Eniwetok and

Bikini Atolls, August 1964

In: Symposium on Radioecology, Proceedings of the Second National Symposium held at Ann Arbor, Michigan, May 15-17, 1967 (Doc. CONF670503) 346-354 (1969) NSA 23, 17977

69-WEL 
WENSTRAND, T. K. See: 71-KER

WERNER, J. SEe: 73-BEY

WEST, J. E., and W. J. Bair

Plutonium inhalation studies $V$. Radiation syndrome in beagles

64-WES

after inhalation of plutonium dioxide

Radiat. Res. 22, 489-506 (1964) NSA 18, 29906

WEST, J. E. See also: 62-PAR

WESTFALL, W. M. See: 59-FRI, 65-LIN

WHALEN, R. P., and S. Davies

Americium contamination incident in a New York State Health

72-WHA

Department laboratory

Radiat. Data Rep. 13, 249-253 (1972) NSA 26, 41497 Also: N.Y.

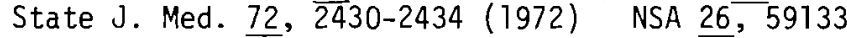

WHICKER, F. W., C. A. Little and T. F. Winsor

Plutonium behavior in the terrestrial environs of the Rocky Flats

74-WHF installation

In: Environmental Surveillance Around Nuclear Installations. Vol.

II (International Atomic Energy Agency, Vienna) 89-103 (1974)

NSA 31,14032

WHIPPLE, H. O. See: 68-SCF

WHITE, M. R., and J. Schubert

The action of salts of zirconium and other metals on plutonium

52-WHI

and yttrium distribution and excretion

J. Pharmaco1. Expt1. Therap. 104, 317-324 (1952) NSA 6, 3206

WHITE, M. R. See also: 50-SCH, 50-SCH-2

WHITSON, S. W. See: 72-PAZ

WIGGINS, A. D. See: 62-BAI-2

WILDUNG, R. E., and T. R. Garland

Influence of soil plutonium concentration on plutonium uptake

and distribution in shoots and roots of barley

J. Agr. Food Chem. 22, 836-838 (1974) NSA 30, 29825

WILKINSON, C. J. See: 72-K.OT, 75-RAB

WILKINSON, P. N., and F. E. Hoecker

Selective placental transmission of radioactive alkaline earths and plutonium

Trans. Kansas Acad. Sci. 56, 341-363 (1953) also Doc. AECU-2400, 33 p.

NSA 2,1863 BA 28, 13017

WILLARD, D. H. See: 61-BAI, 61-BAI-3, 62-BAI, 62-BAI-3, 63-BAI, 74-BAI-4, 62-PAR, 59-TEM

WILLIAMS, A. See: 50-BOY-2

WILLIAMS, J. L. See: 72-LOR, 74-LOR, 75-LOR, 72-TAG, 72-TAG-2, 74-TAG

WILLIAMS, $K$.

Studies of the toxicology of plutonium

Doc. AERE-R-2907, 22 p. (1959) NSA 13, 20023

59-WIL

WILLIAMS, M. H. See: 61-DUR, 69-DUR

WILLIAMS, R. H. See: 70-MAE 
WILLIAMSON, M., and J. Vaughan

Histochemistry of the mucosaccharides in the epiphyseal plate of

67-WIM young rabbits

Nature 215, 711-714 (1967) PD 2, 122T

WILLIAMSON, M. See a1so: 62-HER, 67-VAU

WILSON, D. 0., and J.F. Cline Removal of $239 \mathrm{Pu}, 185 \mathrm{~W}$, and $210 \mathrm{~Pb}$ from soil

$66-W I D$

Nature 209, 941-942 (1966) NSA 20, 22538

WILSON, D. W. See: 74-ANS

WILSON, J. S. See; 68-RIC

WILSON, R. H. 56-WIH

Decontamination of human skin after immersion in a plutonium solution Doc. HW-42030, 31 p. (1956) NSA 11, 11037

WILSON, R. H.

Distribution of plutonium observed in human blood

$56-$ WIH-2

Doc. HW-44341, 5 p. (1956) NSA 33, 5812

WILSON, R. H.

Hanford experience with plutonium contaminated injuries, 1945-1959

Doc. HW-62274, 23 p. (1959)

WILSON, R. H.

A review of significant Hanford plutonium deposition cases

59-WIH-2

In: Doc. WASH-1023, 71-83 (1959) NSA 14, 2268

WILSON, R. H., and W. B. Silker

Plutonium contaminated injury case study and associated use of

$\mathrm{Na}_{4}$ EDTA as a decontaminating agent

Doc. HW-66309, 5 p. (1960) NSA 16, 4393

WILSON, R. H.

Controlling and evaluating plutonium deposition in humans

In: Plutonium handbook: A Guide to the Technology. Vol. 2 (0. J.

Wick, ed., Gordon and Breach, New York) 831-844 (1967) NSA 22 , 8557

WILSON, R. H. [WIH] See also: 58-NOR, and all WIR listings

(a different R. H. Wilson)

WILSON, R. H., R. G. Thomas and J. N. Stannard

Biomedical and aerosol studies associated with field release of plutonium

Doc. WT $-1511,67$ p. (1960) NSA 15, 12697

WILSON, R. H., and J. L. Terry

Plutonium uptake by animals exposed to a non-nuclear detonation of

60-WIH

a plutonium-bearing weapon simulant. Part 1. Field operations

Doc. LIR-665, 45 p. (1965) NSA 19, 31712

WILSON, R. H. , and J. L. Terry

Biological studies associated with a field release of plutonium

In: Inhaled Particles and Vapours II (C. N. Davies, ed., Pergamon

Press, Oxford) 273-290 (1967) NSA 21, 32597

WILSON, R. H., and J. L. Terry

Operation Roller Coaster - Project 0fficers report - Project 4.1.

$60-$ WIR

$67-$ WIH

Plutonium uptake by animals exposed to a non-nuclear detonation

of a plutonium-bearing weapon simulant

Doc. POR-2512 (WT-2512), 162 p. (1968) EP S3, 393 
WILSON, R. H. [WIR] See also: 65-STK, 69-STK-2, and all WIH listings (a different R. H. Wilson)

WILSON, S. A. See: 65-HSI

WINSOR, T. F. See: 74-WHF

WIRTH, J. E.

Management and treatment of exposed personnel

In: Industrial Medicine on the Plutonium Project (R. S. Stone, ed., McGraw-Hi11, New York) 264-275 (1951) EP S2, 85

WIRTH, J.E. See also: 45-HEM

WITHERS, H. R., G. D. 0liver, Jr. and D. W. Glenn

Response of mouse jejunal crypt cells to low dose rate irradiation

71-WIT

with californium neutrons or radium gamma-rays

Radiat. Res. 48, 484-494 (1971) NSA 26, 18064

WITHERS, H. R. See also: 73-CAJ

WONG, K. M., J. C. Burke and V. T. Bowen

Plutonium concentration in organisms of the Atlantic Ocean

In: Health Physics Aspects of Nuclear Facility Siting. Vol. II

(P. G. Voilleque, ed., Idaho Falls, Idaho) 529-539 (1971)

NSA 25,55161

WONG, K. M., V. F. Hodge and T. R. Folsom

Concentrations of plutonium, cobalt, and silver radionuclides in selected Pacific seaweeds

In: Proceedings of Environmental Plutonium Symposium (E. G. Fowler, et al., eds., Doc. LA-4756) 93-98 (1971)

WONG, K. M., V. F. Hodge and T. R. Folsom

Plutonium and polonium inside giant brown algae

Nature 237, 450-462 (1972) NSA 26, 45924

WONG, K. M. See also: 71-BOW, 71-NOS, 74-NOS-2

WOOD, D. See: 67-MOP

WOOD, D. H., J. L. Murray and J. L. Palotay

Correlation of rose bengal clearance and histopathologic change of sheep 1 ivers damaged by $237 \mathrm{~Np}$

Am. J. Vet. Res. 29, 1103-1108 (1968) NSA 22, 33932

WOOD, R., and B. A. Burden

Accumulation of radionuclides in water works filter bed material

71-WON

Nature 213, 637-638 (1967) NSA 21, 16006

WOODHEAD, D. S.

Levels of radioactivity in the marine environment and the dose

commitment to marine organisms

In: Radioactive Contamination of the Marine Environment (International

Atomic Energy Agency, Vienna) 499-525 (1973) NSA 28, 8184

71-WON-2

WOODRUFF, L. See: 47-KIS

WOODRUFF, R. K. See: 73-SEL

WRAIGHT, N. See: 67-MOP 
WRENN, M. E., J. C. Rosen and N. Cohen

72-WRE

In vivo measurement of $241 \mathrm{Am}$ in man

In: Assessment of Radioactive Contamination in Man (International

Atomic Energy Agency, Vienna) 595-621 (1972) NSA 25, 44802

WRENN, M. E.

Environmental levels of plutonium and transplutonium elements

74-WRE

(part of AEC presentation at EPA Plutonium Standards Hearings, December 10-11, 1974)

In: Doc. WASH-1359, 89-112 (1974) NSA 31, 16526

WRENN, M. E. See also: 72-CON, 73-CON, 74-CON, 72-ROJ

WRIGHT, S. R.

$L X$-ray measurement of actinide metabolism using ${ }^{243} \mathrm{Am}$ in mice 
YAEGER, D. J. See: 72-PAH

YANIV, S. S.

Plutonium and americium measurements in humans by $X$ - and gamma-

ray spectral analysis (Thesis, University of Pittsburgh)

Doc. WASH-1241, 183 p. (1973) NSA 28, 2974

YANIV, S. S. See also: 68-WAL

YASKOVA, V. Z. SEe: 70-SMO, 68-TAR

YATES, C.W. See: 65-DOS

YEE, J. See: 69-JEW

YODER, R. E.

74-YOD

Potential source terms and control measures (part of AEC

74-YOD presentation at EPA Plutonium Standards Hearings, December 10-11, 1974)

in: Doc. WASH-1359, 13-86 (1974) NSA 31, 16525

YOKOVLEV, G. N. See: 69-KAP

YOSHIKAWA, K. See: 67-MAO

YOUNG, D. R. See: 73-HOV

YUILE, C. L., F. R. Gibb and P. E. Morrow Dose-related local and systemic effects of inhaled $239 \mathrm{Pu}$ and $239 \mathrm{Pu}$ dioxide in dogs

Radiat. Res. $44,821-834$ (1970) NSA 25, 26929 
ZALIKIN, G. A., Y. I. Moskalev and I. K. Petrovich

68-ZAL Distribution and biological effect of ${ }^{241} \mathrm{Am}$

Radiobiologiya $8,65-71$ (1968) translated in AEC-tr-6950, 107-118 NSA 22, 47473

ZALIKIN, G. A., Y. I. Moskalev, I. K. Petrovich and E. I. Rudnitskaya

69-ZAL Biological effects of $241 \mathrm{Am}$ Radiobiologiya 9, 599-603 (1969) translated in AEC-tr-7109, 169-175

NSA 24,556

ZALIKIN, G. A., and B. A. Popov Influence of DTPA on the acceleration of the elimination of $241 \mathrm{Am}$ in the case of introduction of the isotope into the mammalian organism, lasting up to 300 days (Abstract)

Radiobiologiya 12, 316 (1972) translated in AEC-tr-7362, 238

ZALIKIN, G. A., Y. I. Moskalev, R. M. Lyubimova-Gerasimova, I. K.

Petrovich and $V$. S. Stepanov Distribution and biological action of ${ }^{252} \mathrm{Cf}$

Radiobiologiya 12, 894-897 (1972) translated in AEC-tr-7421, 124-

i28 NSA 28, $2 \overline{990}$

ZALIKIN, G. A., and V. I. Trifonov Distribution of americium 241 in the rat organism as related to the properties of the administered salt

In: Biological Effects of Radiation from External and Internal Sources

(Y. I. Moskalev and V. S. Kalistratova, eds., Meditsina, Moscow)

292-297 (1972) translated in AEC-tr-7457, 427-434 NSA 30, 10016

ZALIKIN, G. A., and B. A. Popov

Influence of DTPA on the acceleration of ${ }^{241}$ Am excretion after chronic intake by rat (in Russian)

In: Proceedings of German-Soviet Working Meeting on the Question of Radiation Protection, Staatliche Zentrale fuer Strahlenschutz, Berlin, 51-56 (1973) NSA 30, 19030

ZALIKIN, G. A., Y. I. Moskalev, A. I. Semenov, Y. S. Zhorova, $72-Z A L$

$72-Z A L-2$

V. N. Streltsova, I. K. Petrovich and V. I. Trifonov Materials on the toxicology of californium-252 (in Russian)

In: Proc. Third Int. Cong. Int. Radiat. Prot. Assn. (W. S. Snyder, ed., Doc. CONF-730901-P1) Vo1. 1, 117-128 (1974) NSA 30, 27262

ZALIKIN, G. A. See also: 67-MOS-2, 71-MOS, 71-MOS-3, 72-MOS-2, 72-MOS-4, 73-MOS, 73-MOS-4, 74-MOS, 74-MOS-2, 74-MOS-4, 73-SEA, 74-SEA

ZALMANZON, Y. E., and 0 . A. Chutkin

Radiation absorbed dose in the lungs from radioactive aerosols

72-ZAY

Med. Radiol. 17(4), 63-68 (1972) translated in RFP-Trans-130

NSA 27, 17686

ZALMANZON, Y. E., and 0. A. Chutkin

Distribution of absorbed dose from alpha-active aerosol particles by tissue depth (in Russian)

Med. Radiol. 17(7) 69-72 (1972) NSA 27, 17689

ZALMANZON, Y. E., and 0 . A. Chutk in Control of the inhaled fraction of radioactive aerosol particles (in Russian)

Tr. Soyuznogo Nauch.-Issled. Inst. Priborostr. 21, 34-39 (1973)

NSA 29, 24526 
ZAPOLSKAYA, N. A., A. V. Fedorova, V. V. Borisova, K. K. Nechaev and

E. I. Dolgirev

Metabolic routes of ${ }^{239} \mathrm{Pu}$ at early periods following its introduction (in Russian)

Med. Radiol. 19(11), 74-76 (1974) NSA 31, 11703

ZHOROVA, E. S. See: 74-MOS-2, 74-ZAL

ZHUIRAVLEVA, A. K. see: 72-KHA, 74-KHA

ZIEMER, P. L. See: 71-MEW, 71-MEW-3

ZLOBIN, V. S.

Accumulation of uranium and plutonium by marine algae

$66-Z L 0$

Radiobiologiya 6, 613-617 (1966) translated in AEC-tr-6773, 219-227

NSA 21, 22372

ZLOBIN, V. S., and 0. V. Mokanu

Mechanisms of the accumulation of $239 \mathrm{Pu}$ and $210 \mathrm{Po}$ by the brown

alga Ascophyllum nodosum and marine phytoplankton

Radiobiologiya 10, 584-589 (1970) translated in AEC-tr-7205, 160-

169 NSA $25,1 \overline{09} 41$

ZLOBIN, V. S., and M. F. Perlyuk

Photosynthesis and the mechanism of the action of cyanide on cell respiration and $23{ }^{9} \mathrm{Pu}$ accumulation by marine algae

Proc. Sci. Res. \& Planning Inst. of Sea Fisheries \& Oceanog. 29, 159-

168 (1971) translated in AEC-tr-7418, 195-206 NSA 27, 28069

ZLOBIN, V. S.

Active phase of assimilation of ${ }^{239} \mathrm{Pu}$ by the marine algae

Ascophyllum nodosum

Proc. Sci. Res. \& Planning Inst. of Sea Fisheries \& Oceanog. 29 ,

$169-175$ (1971) translated in AEC-tr-7418, 207-217 NSA 27, 28070

ZLOBIN, V. S.

Comparative evaluation of accumulation dynamics of some corrosion and fission group radioisotopes and alpha emitters by northern marine algae

In: Radioecology of Water Organisms. II. Distribution and

Migration of Radionuclides in Freshwater and Sea-water Biocenoses

(G. P. Andrumaitis, ed., Izdatelstvo Zinatne, Riga) 242-247 (1973)

translated in AEC-tr-7606, 144-147 NSA 30,21142

ZVONOVA, I. A. See: 74-LIK

ZYLICZ, E. See: 71-JAW, 73-JAW-2 
INDEX CATEGORIES

(and index page on which each appears)

\section{RADIONUCLIDES \\ 1 Neptunium \\ 1 Plutonium- $<238$ \\ 1 Plutonium-238 \\ 1 Plutonium $\rightarrow 239$ \\ 1 Americium \\ 2 Curium \\ 2 Berkelium \\ 2 Californium \\ 3 Einsteinium

$\begin{array}{ll}4 & \text { Trivalent } \\ 4 & \text { Hexavalent } \\ 4 & \text { Chloride } \\ 4 & \text { Citrate } \\ 4 & \text { Fluoride } \\ 5 & \text { Nitrate } \\ 5 & \text { Oxide }\end{array}$

COMPOLINDS OF PLIUTONIUM

PHYSICAL STATE

6 Particles

6 Polymeric Behavior

6 Specific Activity

\section{DISPERSAL MODE}

7 Fallout

7 Industrial

7 Accidents

8 Site-Specific Hanford

Los Alamos

Mound Nevada Test Site "Safety Shots" Rocky Flats

Savannah River Pacific Islands Palomares Thule

\section{EXPOSURE MODE}

$\begin{aligned} 9 & \text { Inhalation or Intratracheal } \\ 9 & \text { Ingestion } \\ 10 & \text { Intramuscular or Wound } \\ 11 & \text { Percutaneous } \\ 11 & \text { Repeated }\end{aligned}$

\section{EXPERIMENTAL ANIMAL}

$\begin{array}{ll}12 & \text { Dog } \\ 12 & \text { Hamster } \\ 12 & \text { Mouse } \\ 13 & \text { Primate } \\ 13 & \text { Rabbit } \\ 13 & \text { Rat } \\ 14 & \text { Swine } \\ 14 & \text { Other }\end{array}$

\section{ORGAIIS, TISSUES, SECRETIONS}

$\begin{array}{ll}15 & \text { Adrenals } \\ 15 & \text { Blood } \\ 15 & \text { Bone } \\ \text { Marrow } \\ 17 & \text { Brain (Nervous System) } \\ 17 & \text { Excreta } \\ & \text { Urine Data Only } \\ 18 & \text { Eyes } \\ 18 & \text { Fetus (Placenta) } \\ 18 & \text { Gastrointestinal Tract } \\ 18 & \text { Gonads } \\ 19 & \text { Hair } \\ 19 & \text { Heart } \\ 19 & \text { Kidney } \\ 19 & \text { Liver } \\ & \text { Bile } \\ 21 & \text { Lung } \\ & \text { Upper Respiratory Tract } \\ 22 & \text { Lymph Node } \\ & \text { Non-Pulmonary } \\ 22 & \text { Mammary Gland } \\ 22 & \text { Milk } \\ 22 & \text { Muscle } \\ 23 & \text { Pituitary } \\ 23 & \text { Skin } \\ 23 & \text { Spleen } \\ 23 & \text { Teeth } \\ 24 & \text { Thyroid } \\ & \end{array}$

METABOLISM

25 Microdistribution Cellular

25 Biochemical Binding

25 Retention

25 Dosimetry

25 Data from Non-Adults

\section{TOXICITY}

31 Dosimetry

31 Acute Effects

31 Survival Data

31 Neoplasia Leukemia

31 Hematological Effects

31 Biochemical Effects

31 Chromosomal Effects

31 Combined Insults

31 Effects in Non-Adults

\section{THERAPEUTIC REMOVAL}

37 Chelate Therapy

37 Non-Chelate Therapy

37 Excretion Data

37 Distribution Data

37 Survival or Tumor Data

37 External Decontamination

37 Colloid Therapy

37 Lavage Therapy

37 Chelate Toxicity

41 Therapy
41 Exposures

41 Dosimetry

41 Excretion Data

41 Body Burden Estimates

41 Autopsy Data

41 Biological Effects

41 Psychosocial Effects

\section{ENVIRONMENTAL DISTRIBUTION}

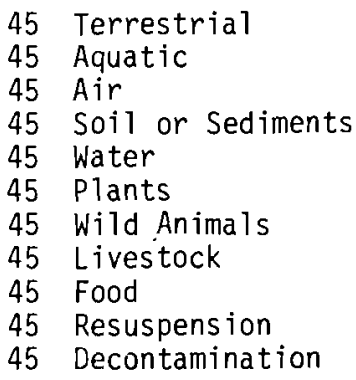

\section{HAZARD EVALUATION}

$\begin{array}{ll}48 & \text { Dosimetry } \\ 48 & \text { Comparative Radionuclide } \\ & \text { Data } \\ 48 & \text { Standards } \\ 48 & \text { Hot Particles } \\ 48 & \text { Risk Estimates }\end{array}$


RADIONUCLIDES

\begin{tabular}{|c|c|c|c|c|c|c|c|c|}
\hline \multicolumn{2}{|l|}{$\mathrm{Np}$} & $<238 \mathrm{Pu}$ & \multicolumn{4}{|l|}{${ }^{238} \mathrm{Pu}$} & $>239 \mathrm{Pu}$ & $\mathrm{Am}$ \\
\hline $\begin{array}{l}61-\mathrm{BAI}-5 \\
63-\mathrm{BAI}-2 \\
74-\mathrm{BAI}-5 \\
62-\mathrm{BAL}-2 \\
64-\mathrm{BAL} \\
74-\mathrm{BEG}-3 \\
70-\mathrm{BEJ} \\
68-\mathrm{BRH} \\
75-\mathrm{BRI} \\
72-\mathrm{BUL}-3 \\
72-\mathrm{BUL}-4 \\
62-\mathrm{CAB} \\
73-\mathrm{CAG} \\
63-\mathrm{CAH} \\
71-\mathrm{CRL} \\
58-\mathrm{DAJ} \\
60-\mathrm{DUR} \\
62-\mathrm{DUR} \\
74-\mathrm{DUR}-2 \\
72-\mathrm{FIS} \\
75-\mathrm{FOL} \\
63-\mathrm{FOS} \\
47-\mathrm{HAM} \\
48-\mathrm{HAM} \\
49-\mathrm{HAM} \\
49-\mathrm{HAM}-2 \\
74-\mathrm{HAN} \\
75-\mathrm{HAN} \\
74-\mathrm{HEA} \\
73-\mathrm{HOC} \\
73-\mathrm{KEC} \\
74-\mathrm{KHA} \\
74-\mathrm{KHO} \\
66-\mathrm{KRE} \\
68-\mathrm{KRE} \\
70-\mathrm{KRE} \\
46-\mathrm{LAH} \\
68-\mathrm{LEM} \\
71-\mathrm{LEV} \\
71-\mathrm{LEV}-2 \\
71-\mathrm{LEV}-3 \\
72-\mathrm{LEV} \\
72-\mathrm{LEV}-2 \\
74-\mathrm{LEV} \\
74-\mathrm{LEV}-2 \\
75-\mathrm{LEV} \\
72-\mathrm{YYU}-2 \\
66-\mathrm{MAH} \\
67-\mathrm{MAH} \\
71-\mathrm{MAH} \\
67-\mathrm{MAT} \\
70-\mathrm{MCO} \\
62-\mathrm{MCR} \\
66-\mathrm{MCR} \\
74-\mathrm{MIW} \\
75-\mathrm{MOG} \\
73-\mathrm{MOR} \\
73-\mathrm{MOR}-3 \\
67-\mathrm{MOS}-2 \\
69-\mathrm{MOS}-4 \\
71-\mathrm{MOS} \\
\text { 7. }\end{array}$ & 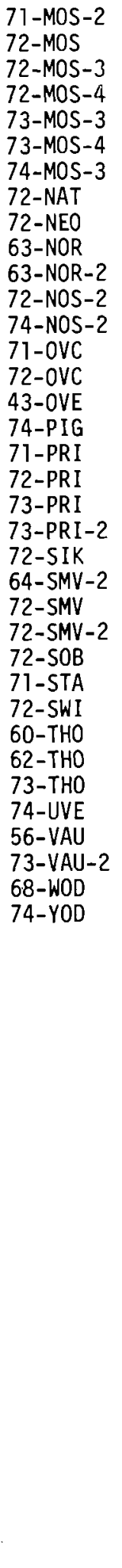 & 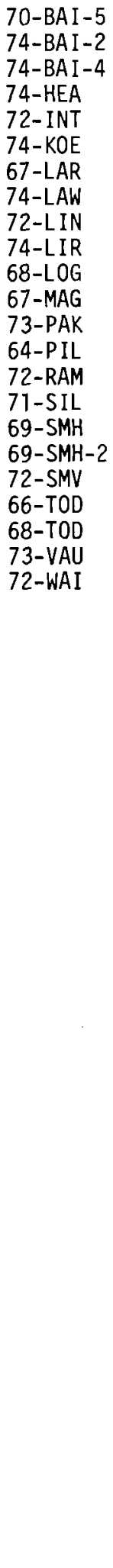 & $\begin{array}{l}70-A D M \\
75-A D M \\
72-A L D \\
70-A N H \\
68-A N O \\
71-A R K \\
70-B A I \\
70-B A I-2 \\
70-B A I-5 \\
73-B A I \\
74-B A I \\
74-B A I-2 \\
74-B A I-3 \\
74-B A I-5 \\
74-B A I-6 \\
74-B A I-7 \\
64-B A L \\
67-B A L \\
74-B A N \\
74-B E G-3 \\
71-B E R \\
68-B R H \\
75-B R I \\
69-B U L \\
62-C A B \\
73-C A G \\
70-C O D \\
65-C O M \\
60-C R A \\
74-C R D \\
75-C R D \\
46-C R J \\
71-C R L \\
72-C R 0 \\
71-C U M \\
68-D E B \\
69-D E B \\
72-D I X \\
72-D O W \\
71-D R E \\
71-D U R \\
72-D U R-2 \\
74-D U R-2 \\
72-E D L \\
72-E D L-2 \\
73-E I S \\
74-E M R \\
74-E M R-2 \\
72-E T I \\
72-F I S \\
75-F L E \\
60-F O R \\
72-G A V \\
68-G E S \\
68-G E S-2 \\
75-G O F \\
71-H A E \\
74-H A K-1 \\
74-H A K-2 \\
45-H A M \\
45-H A M-2\end{array}$ & 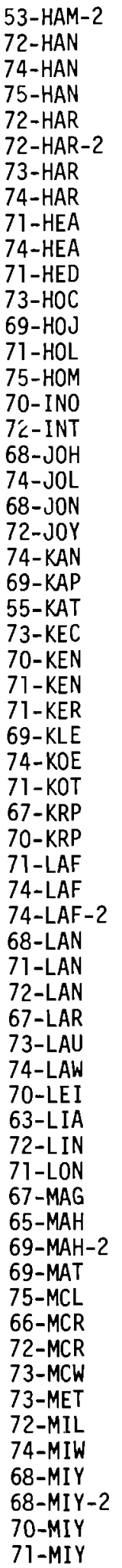 & 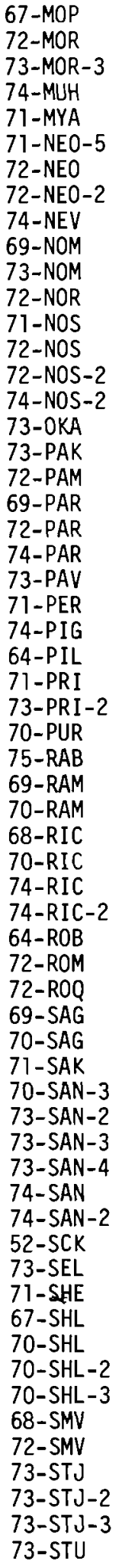 & 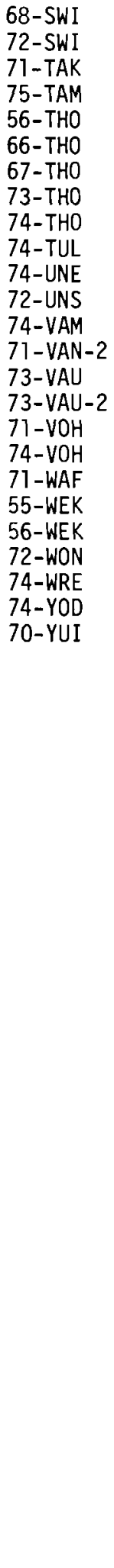 & 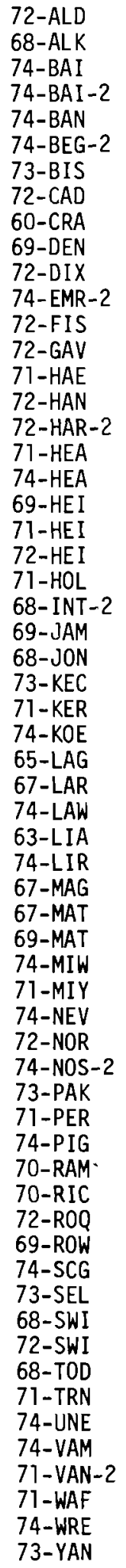 & 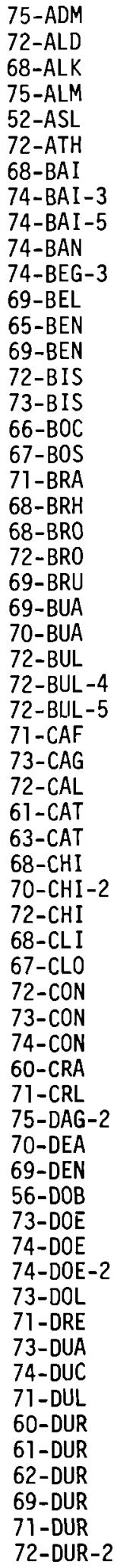 \\
\hline
\end{tabular}


RADIONUCLIDES

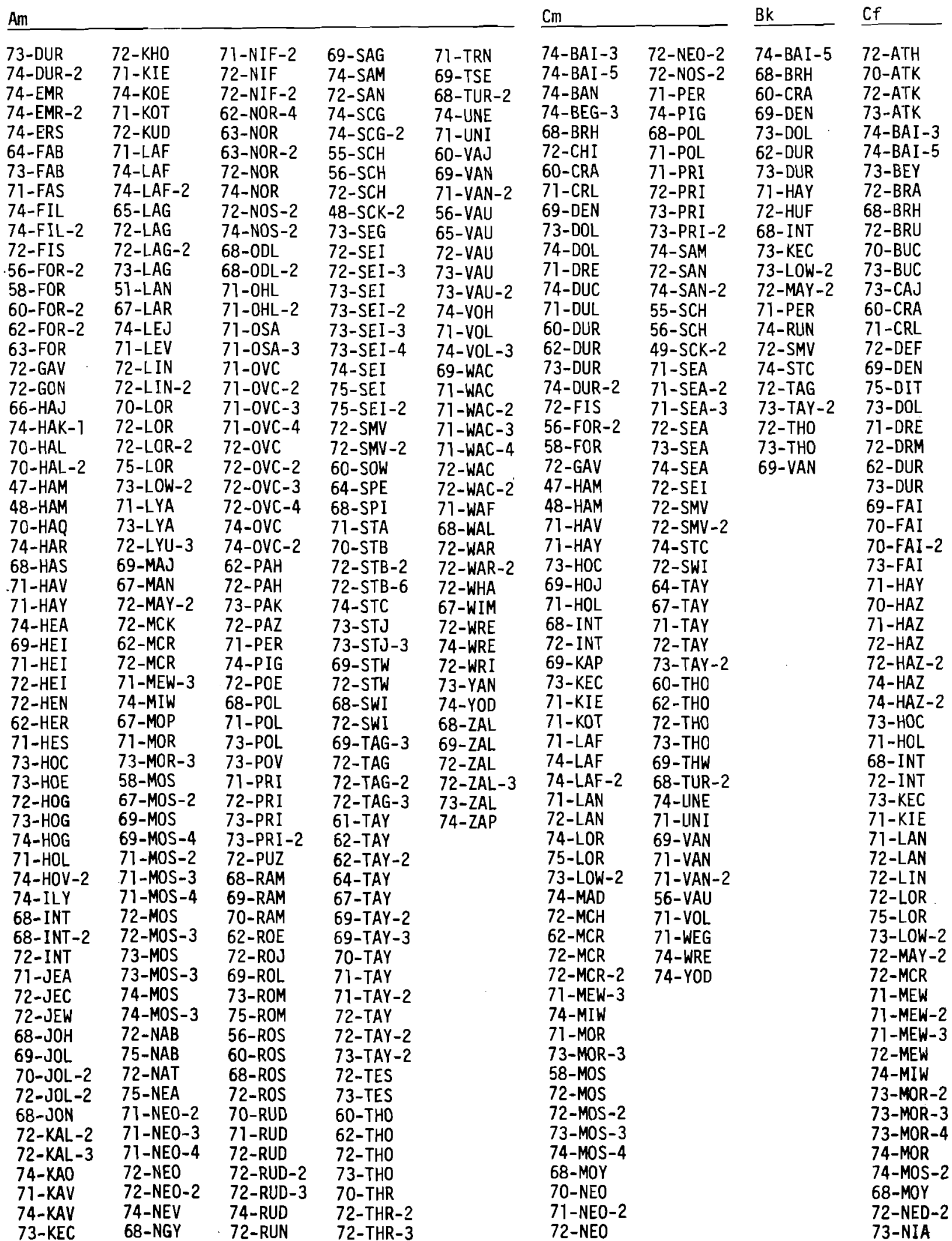


RADIONUCLIDES

\begin{tabular}{|c|c|}
\hline & Es \\
\hline 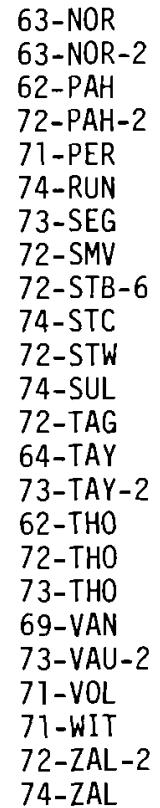 & 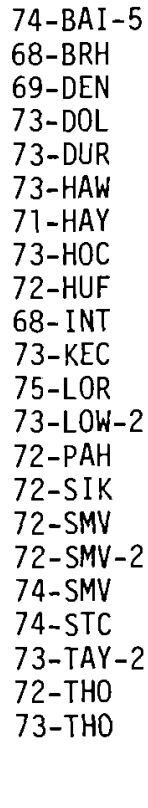 \\
\hline
\end{tabular}


COMPOUNDS OF PLUTONIUM

Trivalent Hexavalent

\begin{tabular}{|c|c|c|}
\hline $\begin{array}{l}\text { 45-ABR } \\
47-A B R \\
73-B A I \\
74-B A I \\
74-B A I-2 \\
69-B U L \\
47-C A R \\
74-D U R-2 \\
44-H A M \\
44-H A M-2 \\
45-H A M \\
47-H A M \\
48-H A M \\
72-I N T \\
48-J A L \\
70-L A F \\
65-L A G \\
51-L A N \\
59-L A N \\
64-L A N \\
67-L Y U \\
74-M A L \\
73-N E C \\
73-N E C-2 \\
73-N E C-3 \\
67-N E 0 \\
65-N I S \\
71-P R I \\
73-P R I-2\end{array}$ & $\begin{array}{l}45-A B R \\
47-A B R \\
72-A L D \\
69-A N T \\
73-\text { BAI } \\
74-\text { BAI } \\
74-\text { BAI-2 } \\
62-\text { BEL-2 } \\
75-\text { BRI } \\
45-\text { BRM } \\
69-\text { BUL } \\
72-\text { BUL-2 } \\
47-\text { CAR } \\
69-\text { CHA-2 } \\
45-C O K \\
45-C O K-2 \\
46-C R J \\
60-D U R \\
71-D U R \\
72-D U R \\
72-D U R-2 \\
74-D U R-2 \\
64-E R O \\
66-E R O \\
69-E R 0 \\
71-E R O \\
45-F I D \\
74-F I L-2 \\
44-H A M\end{array}$ & 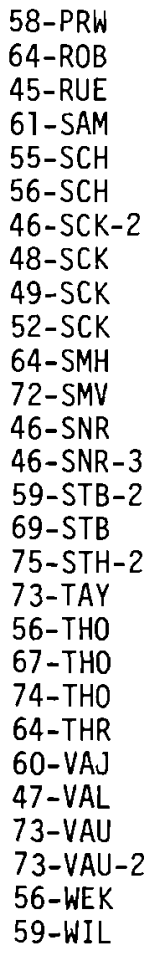 \\
\hline
\end{tabular}

58-PRW 44-HAM-2

64-ROB 45-HAM

72-SAN 47-HAM

46-SCK-2 48-HAM

48-SCK 72-INT

72-SMV 48-JAL

68-TAS 46-JAO

62-TAY-2 53-JOF

64-TAY 50-KAW

73-TAY 63-KAW

67-THO 72-KHA-2

66-TOD 74-KHA

73-VAU 45-LAN

70-WAR 51-LAN

56-WEK 59-LAN

59-WIL 60-LAN

64-LAN

69-LAN

62-LEM

64-LYM

66-LYU

67-LYU

74-MAL

72-MOS

45-NIC-2

62-NIF

65-NIS

$72-N O R$

63-OLA

46-PAE

71-PRI

73-PRI-2
Chloride Citrate

\begin{tabular}{|c|c|c|c|c|c|}
\hline $\begin{array}{l}69-\mathrm{BAI} \\
73-\mathrm{BAI} \\
\text { 74-BAI -2 } \\
\text { 74-BAI-5 } \\
69-\mathrm{BUL} \\
47-\mathrm{CAR} \\
71-\mathrm{DOL} \\
74-\mathrm{DUR}-2 \\
\text { 74-GRO-2 } \\
62-\mathrm{HER} \\
51-\mathrm{LAN} \\
\text { 74-LEJ } \\
74-\mathrm{MAL} \\
\text { 73-NEC } \\
73-\mathrm{NEC}-2 \\
\text { 70-RAM } \\
64-\mathrm{SAB} \\
\text { 72-SAN } \\
\text { 71-SCR } \\
68-\mathrm{TAS} \\
\text { 71-TAS }\end{array}$ & $\begin{array}{l}45-A B R \\
47-A B R \\
69-A N T \\
72-A R I \\
56-A R N \\
57-A R N \\
59-A R N \\
62-A R N \\
52-A S L-2 \\
70-B A I-2 \\
71-B A I \\
73-B A I \\
74-B A I \\
74-B A I-2 \\
74-B A I-3 \\
74-B A I-5 \\
74-B A I-6 \\
74-B A I-7 \\
62-B A L \\
62-B A L-2 \\
62-B A L-3 \\
62-B A L-4 \\
64-B A L\end{array}$ & 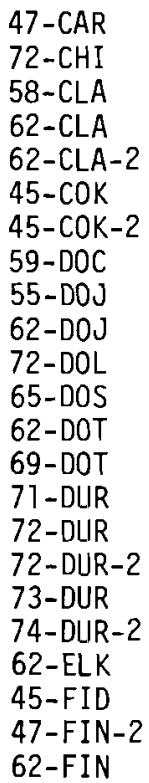 & $\begin{array}{l}68-L O G \\
71-L Y A \\
64-L Y U \\
64-L Y U-2 \\
66-L Y U \\
66-L Y U-2 \\
67-L Y U \\
68-L Y U \\
69-L Y U \\
69-L Y U-3 \\
72-L Y U \\
69-M A H \\
74-M A H \\
71-M A O-3 \\
72-\text { MAY } \\
72-M A Y-2 \\
68-M C B \\
66-M C R \\
73-M E T \\
61-M O S \\
62-M O S \\
65-M O S \\
66-M O S-2\end{array}$ & 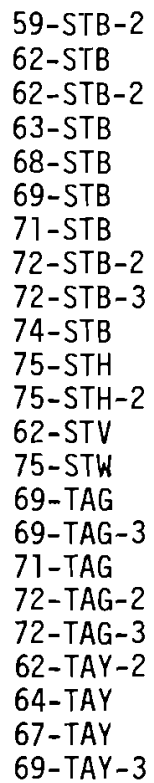 & $\begin{array}{l}\text { 71-BAI } \\
73-\mathrm{BAI} \\
74-\mathrm{BAI}-2 \\
74-\mathrm{BAI}-3 \\
74-\mathrm{BAI}-5 \\
74-\mathrm{BAI}-6 \\
74-\mathrm{BAI}-7 \\
57-\mathrm{BAL} \\
74-\mathrm{DUR}-2 \\
74-\mathrm{JOR} \\
74-\mathrm{KOS}-2 \\
74-\mathrm{LEJ} \\
74-\mathrm{MAL} \\
71-\mathrm{MIS} \\
73-\mathrm{PAF} \\
73-\mathrm{PAK} \\
73-\mathrm{SCG} \\
68-\mathrm{SCL} \\
73-\mathrm{SEL} \\
73-\mathrm{TAY} \\
67-\mathrm{THO} \\
66-\mathrm{VER}-2\end{array}$ \\
\hline
\end{tabular}

67-THO 66-BAL 45-FIR 69-MOS-3 73-TAY

73-VAU 67-BAL 57-FOR 72-MOS 74-TEA

72-BAL 53-HAK 73-MOS-2 56-THO

72-BAL-2 45-HAM 73-MOS-3 67-THO

72-BAX 74-HEA 47-MUN 74-THO

73-BAX 48-HEL-2 45-MUR 64-THR

73-BAX-2 74-HOG 74-NEV 66-TRE-2

59-BEL 75-HOG 71-NIF 66-TRU-3

60-BEL 72-INT 72-NOR 62-TSE

60-BEL-2 72-JAM 71-OVC 68-TUR-2

61-BEL 46-JAO 72-OVC 65-VAU

62-BEL-3 61-JEW 74-OVC 67-VAU

62-BEL-4 62-JEW 74-OVC-2 73-VAU

62-BEL-5 72-JEW 72-PAR 73-VAU-2

64-BEL 53-JOF 72-PES 58-VOG

64-BEL-3 64-KAL 72-PES-2 71-VOL

65-BEN 69-KAL 74-POM 74-VOL-2

73-BIS 72-KAL 64-ROB 74-VOL-3

66-BOC 58-KAW 56-ROS-2 56-WEK

70-BOC 73-KEC 57-ROS 52-WHI

74-BRA 72-KHA-2 69-ROS 59-WIL

45-BRM 71-KOS 45-RUE

69-BRU-2 71-KOS-2 71-RYS

71-BRU 72-KOS-2 70-SAN-3

72-BRU 67-KUD 72-SAN

74-BUK 69-KUD 74-SCG-2

61-BUL 45-LAN 50-SCH

67-BUL 51-LAN 71-SEI

68-BUL 59-LAN 72-SEI

68-BLIL-2 60-LAN 72-SEI-2

69-BUL 62-LAN 74-SHV

69-BUL-2 64-LAN 69-SMH

70-BUL 74-LIK 58-SMV

71-BUL-2 60-LIN 61-SMV

$71-B U L-3$ 62-LIN 64-SMV

71-BUL-4 65-LIN 46-SNR

62-BUS 68-LIN 71-STA

72-BUS 72-LIN 59-STB
Fluoride

71-BAI

74-BAI -2

74-BAI-6

4-BAI-7

4-KOS-2

-LES

71-MIS

3-SEL

67-THO
4-DUR-2 
COMPOUNDS OF PLUTONIUM

Nitrate

Oxide

\begin{tabular}{|c|c|c|c|c|c|c|c|c|}
\hline $\begin{array}{l}45-A B R \\
46-A B R \\
47-A B R \\
72-A I D \\
64-B A D \\
62-B A I-3 \\
63-B A I-2 \\
64-B A I \\
69-B A I \\
70-B A I-2 \\
71-B A I \\
73-B A I \\
74-B A I \\
74-B A I-2 \\
74-B A I-3 \\
74-B A I-4 \\
74-B A I-5 \\
74-B A I-6 \\
74-B A I-7 \\
58-B A L \\
61-B A L \\
62-B A L-2 \\
45-B A R \\
72-B A X \\
66-B E A \\
59-B E L \\
60-B E L-2 \\
61-B E L \\
62-B E L \\
62-B E L-3 \\
62-B E L-4 \\
62-B E L-5 \\
64-B E L-2 \\
68-B E M \\
65-B E N \\
72-B I S \\
73-B I S \\
67-B L E \\
69-B L E \\
69-B L E-2 \\
71-B L E \\
61-B 0 G \\
62-B O G \\
45-B R M \\
59-B U K \\
61-B U K \\
62-B U K \\
69-B U K \\
74-B U K \\
69-B U L \\
72-B U L \\
72-B U L-4 \\
62-B U S \\
47-C A R \\
68-C H I \\
70-C H I \\
70-C H I-2 \\
45-C O K \\
74-C R D \\
75-C R D \\
74-D A N \\
\text {-BI }\end{array}$ & 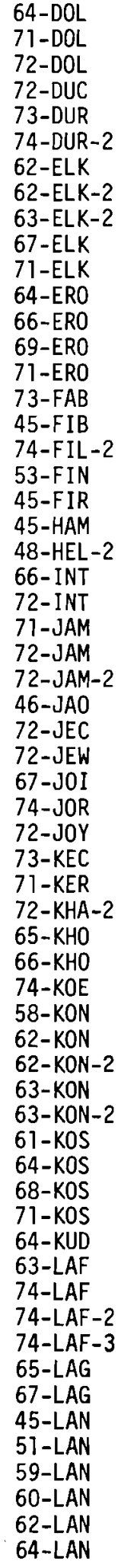 & 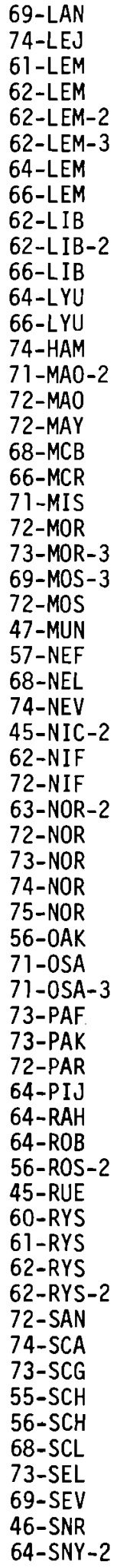 & 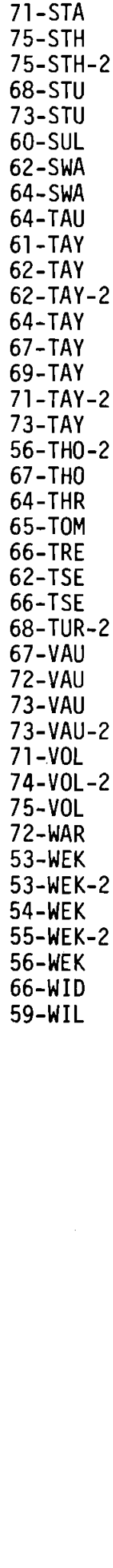 & $\begin{array}{l}45-A B R \\
47-A B R \\
68-A D E \\
73-A D E \\
75-A D M \\
64-A N B \\
52-A S L \\
66-B A C \\
60-B A I \\
61-B A I \\
61-B A I-2 \\
61-B A I-3 \\
61-B A I-4 \\
62-B A I \\
62-B A I-2 \\
62-B A I-3 \\
63-B A I \\
63-B A I-2 \\
64-B A I \\
66-B A I \\
68-B A I \\
69-B A I \\
70-B A I \\
70-B A I-2 \\
70-B A I-4 \\
71-B A I \\
73-B A I \\
74-B A I \\
74-B A I-2 \\
74-B A I-3 \\
74-B A I-5 \\
74-B A I-6 \\
74-B A I-7 \\
66-B E A \\
72-B I S \\
73-B I S \\
59-B 0 E \\
74-B R A \\
73-B R I \\
69-B U L \\
72-B U S \\
71-C A F \\
68-C A S \\
63-C A T \\
64-C L A \\
64-C L A-2 \\
65-C L A \\
66-C L A \\
72-C R D \\
73-C R D \\
75-C R D \\
73-D A G \\
75-D A G \\
75-D A G-2 \\
72-D I L \\
72-D I X \\
64-D 0 C \\
71-D 0 L \\
72-D O L \\
72-D U C \\
\text {-DI }\end{array}$ & $\begin{array}{l}74-\mathrm{DUC} \\
74-\mathrm{DUR}-2 \\
72-\mathrm{EDL} \\
67-\mathrm{ETI} \\
72-\mathrm{FIS} \\
75-\mathrm{FLE} \\
67-\mathrm{FRD} \\
72-\mathrm{GAV} \\
74-\mathrm{GAV} \\
68-\mathrm{GES} \\
68-\mathrm{GES}-2 \\
70-\mathrm{GJO} \\
75-\mathrm{GOF} \\
72-\mathrm{GOM} \\
73-\mathrm{GOM} \\
74-\mathrm{GOM} \\
45-\mathrm{HAM} \\
47-\mathrm{HAM} \\
53-\mathrm{HAM} \\
74-\mathrm{HAN} \\
75-\mathrm{HAN} \\
68-\mathrm{HAS} \\
74-\mathrm{HEA} \\
69-\mathrm{HEI} \\
71-\mathrm{HEI} \\
72-\mathrm{HEI} \\
61-\mathrm{HOR} \\
71-\mathrm{HOW} \\
66-\mathrm{INT} \\
72-\mathrm{INT} \\
72-\mathrm{JEC} \\
72-\mathrm{JEW} \\
67-\mathrm{JOI} \\
69-\mathrm{JOL} \\
70-\mathrm{JOL} \\
72-\mathrm{JOL} \\
72-\mathrm{JOL}-2 \\
74-\mathrm{JOL} \\
74-\mathrm{JOR} \\
74-\mathrm{KAN} \\
69-\mathrm{KAP} \\
68-\mathrm{KAR} \\
73-\mathrm{KEC} \\
61-\mathrm{KIN} \\
74-\mathrm{KOE} \\
69-\mathrm{KOT} \\
71-\mathrm{KOT} \\
72-\mathrm{KOT} \\
70-\mathrm{KUN} \\
70-\mathrm{KUN}-2 \\
70-\mathrm{KUN}-3 \\
71-\mathrm{KUN} \\
74-\mathrm{LAF} \\
65-\mathrm{L} \text {-LAG-2 } \\
60-\mathrm{LAAN}-2 \\
62-\mathrm{LANN} \\
64-\mathrm{LAN} \\
\text { 72 }\end{array}$ & 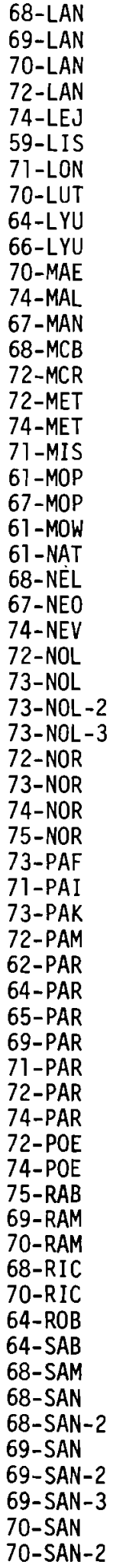 & 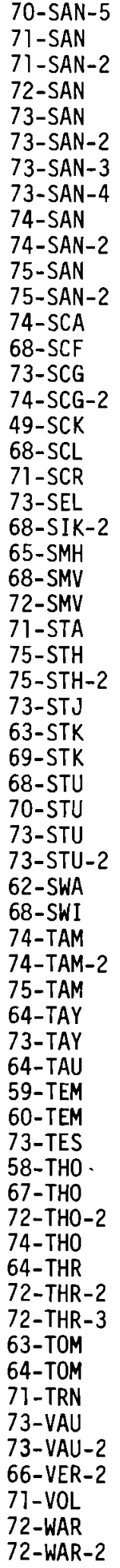 & $\begin{array}{l}\text { 75-WAS } \\
71-W E H \\
64-W E S \\
59-W I L \\
60-W I R \\
74-Y O D \\
70-Y U I\end{array}$ \\
\hline
\end{tabular}


PHYSICAL STATE

Particles

\begin{tabular}{|c|c|c|c|c|c|}
\hline $\begin{array}{l}\text { 47-ABR } \\
68-A D E \\
73-A D E \\
70-A D M \\
74-A L B \\
64-A N B \\
67-A N B \\
74-A N E \\
73-A N S \\
69-A N T \\
52-A S L \\
66-B A C \\
60-B A I \\
61-B A I \\
61-B A I-2 \\
61-B A I-3 \\
61-B A I-4 \\
61-B A I-5 \\
62-B A I \\
62-B A I-2 \\
62-B A I-3 \\
63-B A I \\
63-B A I-2 \\
64-B A I \\
66-B A I \\
68-B A I \\
69-B A I \\
70-B A I \\
70-B A I-2 \\
70-B A I-5 \\
71-B A I \\
73-B A I \\
74-B A I \\
74-B A I-2 \\
74-B A I-3 \\
74-B A I-5 \\
74-B A I-6 \\
74-B A I-7 \\
74-B A N \\
74-B E G \\
74-B E G-2 \\
73-B I S \\
59-B 0 E \\
74-B R A \\
73-B R I \\
75-B R I \\
74-B R J \\
67-B R T \\
69-B U K \\
69-B U L \\
72-B U L-4 \\
72-B U S \\
71-C A F \\
60-C A S \\
68-C A S \\
63-C A T \\
68-C H A \\
69-C H A \\
69-C H A-2 \\
64-C L A \\
64-C L A-2\end{array}$ & $\begin{array}{l}\text { 65-CLA } \\
66-\mathrm{CLA} \\
45-\mathrm{COK} \\
72-\mathrm{CRD} \\
73-\mathrm{CRD} \\
74-\mathrm{CRD} \\
75-\mathrm{CRD} \\
73-\mathrm{DAG} \\
75-\mathrm{DAG} \\
75-\mathrm{DAG}-2 \\
61-\mathrm{DAV} \\
69-\mathrm{DEA} \\
72-\mathrm{DIX} \\
59-\mathrm{DOC} \\
64-\mathrm{DOL} \\
71-\mathrm{DOL} \\
72-\mathrm{DOL} \\
72-\mathrm{DOL}-2 \\
74-\mathrm{DOL} \\
73-\mathrm{DUR} \\
74-\mathrm{DUR}-2 \\
64-\mathrm{EAK} \\
72-\mathrm{EDL} \\
72-\mathrm{EDL}-2 \\
74-\mathrm{ELD} \\
74-\mathrm{EMR}-2 \\
64-\mathrm{ERO} \\
71-\mathrm{ERO} \\
67-\mathrm{ETI} \\
72-\mathrm{ETI} \\
64-\mathrm{EVI} \\
67-\mathrm{FIS} \\
72-\mathrm{FIS} \\
75-\mathrm{FLE} \\
68-\mathrm{FOW} \\
67-\mathrm{FRD} \\
65-\mathrm{FUQ} \\
72-\mathrm{GAV} \\
74-\mathrm{GAV} \\
68-\mathrm{GES} \\
68-\mathrm{GES}-2 \\
74-\mathrm{GIL} \\
70-\mathrm{GJO} \\
67-\mathrm{GLA} \\
75-\mathrm{GOF} \\
75-\mathrm{GOF}-2 \\
72-\mathrm{GOM} \\
73-\mathrm{GOM} \\
74-\mathrm{GOM} \\
74-\mathrm{GRO} \\
75-\mathrm{GUD} \\
75-\mathrm{HAI} \\
45-\mathrm{HAM} \\
47-\mathrm{HAM} \\
53-\mathrm{HAM} \\
72-\mathrm{HAN} \\
74-\mathrm{HAN} \\
75-\mathrm{HAN} \\
72-\mathrm{HAR} \\
71-\mathrm{HEA}-2 \\
74-\mathrm{HEA}\end{array}$ & 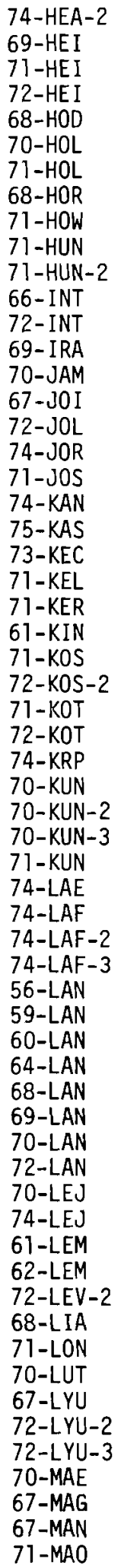 & 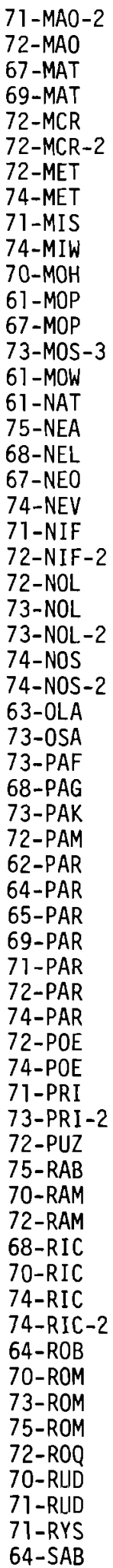 & 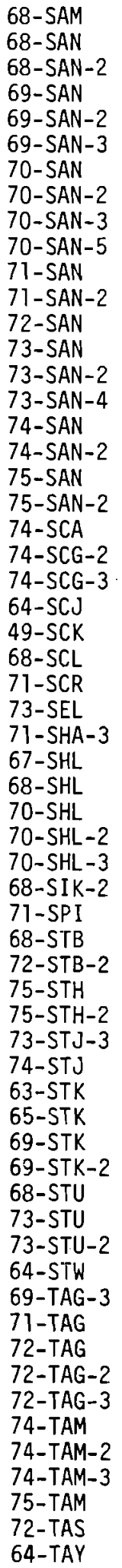 & 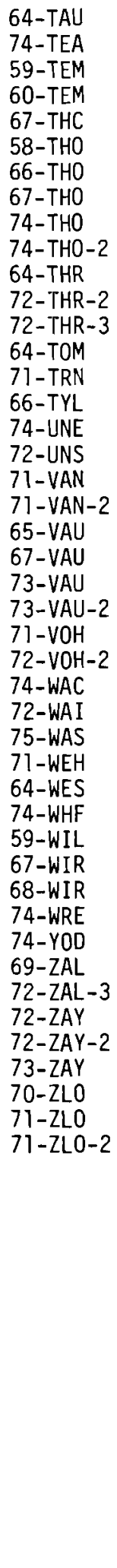 \\
\hline
\end{tabular}

Specific Polymeric Behavior

70-AND 64-MAR 70-ADM

62-BAI-3 72-MAY 75-ADM

74-BAI 72-MAY-2 74-ANE

74-BAI-2 75-MOG 73-BAI

74-BAI-4 72-MOS-4 74-BAI -2

67-BAL 73-MOS-3 74-BAI-3

45-BAR 72-NAT 74-BAI -4

73-BAX 67-NEO 74-BAI-5

62-BEL 72-OVC 74-BAI-6

73-BIS 71-POL 74-BAI-7

74-BUK 64-RAH 67-BAL

68-BUL-2 60-ROS 72-DIX

69-BUL 67-ROS 74-DUR-2

72-BIIL 68-ROS 72-EDL-2

72-BIIL-2 68-ROS-2 74-EMR

72-BLIL-4 69-ROS-2 74-EMR-2

63-CAT 72-ROS 75-FLE

45-COK 72-ROS-2 74-HAN

74-DAN 73-ROS 75-HAN

71-DOL 73-SAN-2 74-HEA

73-DUR 50-SCH 72-INT

74-DUR-2 50-SCH-2 74-KAN

64-ERO 61-SCH-2 69-KAP

66-ERO 61-SCH-3 71-LAF

72-FIS 72-SCH 74-LAF

68-INT 71-SEI-2 72-LIN

72-INT 68-SIK 67-MAG

71-JAM 72-SIK 69-MAH-2

72-JEW 72-SIK-2 72-MCR-2

71-JOS 65-SMH 75-MOG

71-KAS 72-SMV 67-MOP

72-KAS 62-STB-2 72-MOR

75-KAS 75-STH 68-MOY

73-KEC 75-STH-2 72-NEO

72-KHA-2 73-STJ 69-PAR

74-KHA 75-STW 72-PAR

74-KOE 70-TAS 74-PAR

59-LAN 62-TAY-2 68-RIC

64-LAN 69-TAY-3 70-RIC

69-LAN 71-TAY-2 73-SAN-2

61-LEM 72-TAY 73-SAN-3

62-LEM-2 72-TAY-2 73-SAN-4

71-LEV-2 73-TAY 74-SAN

60-LIN 73-TAY-2 64-SMV-2

62-LIN 67-THO 72-SMV

65-LIN 74-THO 73-STJ

68-LIN 71-TRN 67-THO

68-LIN-2 68-TUR-2 74-THO

69-LIN 47-VAL 71-VAN-2

72-LIN 67-VAU 73-VAU

72-LIN-2 73-VAU 70-YUI

69-MAH-2 73-VAU-2

74-MAH 71-VOL

69-MAJ 72-ZAL-3

73-MAJ

74-MAL

71-MAO

71-MAO-3

72-MAO

62-MAR

63-MAR 
DISPERSAL MODE

Fallout

\begin{tabular}{|c|c|c|}
\hline $\begin{array}{l}63-\mathrm{ALE} \\
68-\mathrm{ALK} \\
70-\mathrm{ARK} \\
74-\mathrm{BAI} \\
74-\mathrm{BAI}-2 \\
74-\mathrm{BAI}-3 \\
67-\mathrm{BAJ} \\
74-\mathrm{BAN} \\
74-\mathrm{BEG} \\
74-\mathrm{BEG}-2 \\
74-\mathrm{BEG}-3 \\
71-\mathrm{BOW} \\
69-\mathrm{BUL} \\
74-\mathrm{BUR} \\
73-\mathrm{CAM} \\
74-\mathrm{CHD} \\
65-\mathrm{CHE} \\
65-\mathrm{COM} \\
71-\mathrm{COR} \\
64-\mathrm{COS} \\
68-\mathrm{DEB} \\
69-\mathrm{DEB} \\
69-\mathrm{DEB}-2 \\
72-\mathrm{DIX} \\
73-\mathrm{EIS} \\
63-\mathrm{FOS} \\
61-\mathrm{FRJ} \\
75-\mathrm{GOF} \\
75-\mathrm{GOF}-2 \\
74-\mathrm{GRO} \\
75-\mathrm{GUD} \\
71-\mathrm{HAE} \\
74-\mathrm{HAK}-1 \\
72-\mathrm{HAN} \\
74-\mathrm{HAN} \\
75-\mathrm{HAN} \\
71-\mathrm{HAR} \\
72-\mathrm{HAR} \\
72-\mathrm{HAR}-2 \\
73-\mathrm{HAR} \\
74-\mathrm{K} \\
74-\mathrm{HAR} \\
62-\mathrm{HIN} \\
68-\mathrm{HAN} \\
68-\mathrm{HOD} \\
69-\mathrm{HOJ} \\
75-\mathrm{HOM} \\
73-\mathrm{HOV} \\
74-\mathrm{HOV} \\
70-\mathrm{INO} \\
71-\mathrm{JOR} \\
67-\mathrm{KAU} \\
70-\mathrm{KEN} \\
71-\mathrm{KEN} \\
69-\mathrm{KLE} \\
62-\mathrm{KLO} \\
62-\mathrm{KRP} \\
\text { 70-KRP } \\
\text { 70 }\end{array}$ & 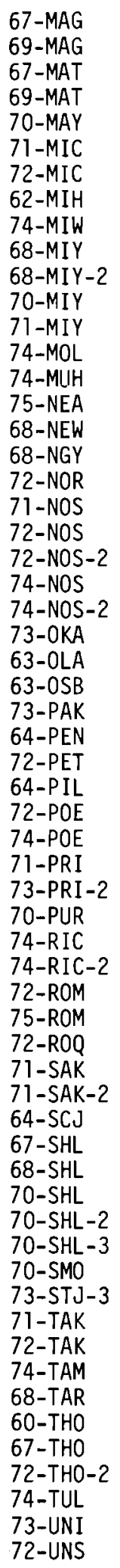 & $\begin{array}{l}71-\text { VOH } \\
74-\text { VOH } \\
74-\text { WHF } \\
71-\text { WON } \\
71-\text { WON-2 } \\
67-\text { WOR } \\
73-\text { WOS } \\
74-\text { WRE } \\
74-\text { YOD }\end{array}$ \\
\hline
\end{tabular}

Industrial

\begin{tabular}{|c|c|}
\hline 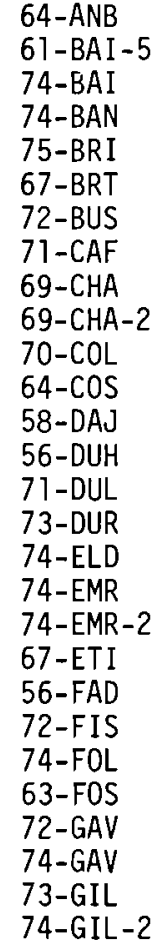 & 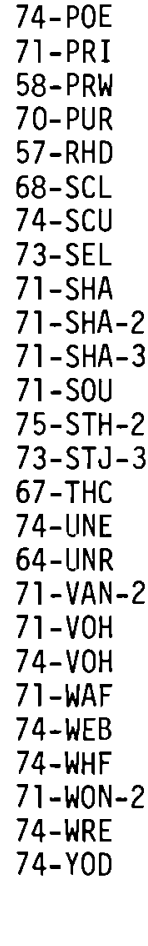 \\
\hline
\end{tabular}

74-GIL-3

74-HAK-2

74-HAN

75-HAN

74-HAP

68-HAS

71-HAS

68-HOR

74-HOV

$71-J O R$

74-JOR

74-KRP

73-KUB

68-LAN

71-LAN

74-LIR

70-MAE

75-MCL

71-MIC

72-MIC-2

73-MIC

64-MIS

71-MIS

74-MIW

74-MOA

68-MOY

72-NAT

58-NOR

72-NOR-2

71-PAI

73-PAK

74-PIG

72-POE
Accidents

\begin{tabular}{|c|c|c|c|}
\hline 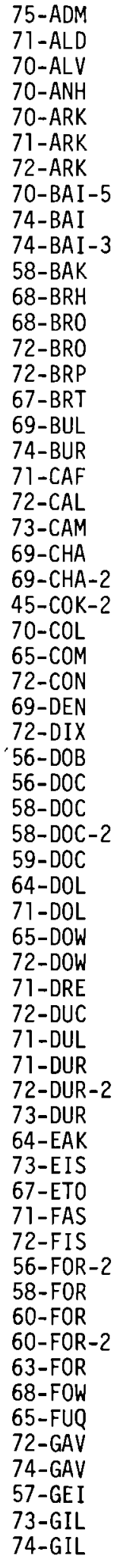 & 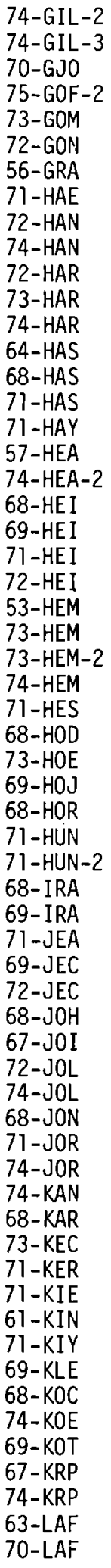 & $\begin{array}{l}65-L A G \\
67-L A G \\
67-L A G-2 \\
69-L A G \\
71-L A G \\
72-L A G \\
72-L A G-2 \\
73-L A G \\
56-L A N \\
57-L A N \\
59-L A N \\
60-L A N \\
62-L A N \\
64-L A N \\
66-L A N \\
68-L A N \\
69-L A N \\
70-L A N \\
68-L A R \\
63-L I A \\
64-L I A \\
68-L I A \\
73-L O W \\
73-L O W-2 \\
62-L U S \\
67-L U S \\
70-M A E \\
67-M A N \\
75-M C L \\
72-M C R \\
71-M I C \\
72-M I C-2 \\
73-M I C \\
62-M I H \\
72-M I L \\
64-M I S \\
71-M I S \\
70-M I Y \\
74-M O A \\
72-N E L-2 \\
68-N E W \\
72-N O J \\
56-N O R \\
56-N O R-2 \\
58-N O R \\
60-N O R \\
62-N O R-2 \\
62-N O R-3 \\
62-N O R-4 \\
63-N O R \\
63-N O R-2 \\
69-N O R \\
72-N O R-2 \\
73-N O R \\
74-N O R \\
68-O D L \\
68-O D L-2 \\
71-O H L \\
71-O H L-2 \\
73-O H L \\
71-P A I \\
\text { 7. }\end{array}$ & 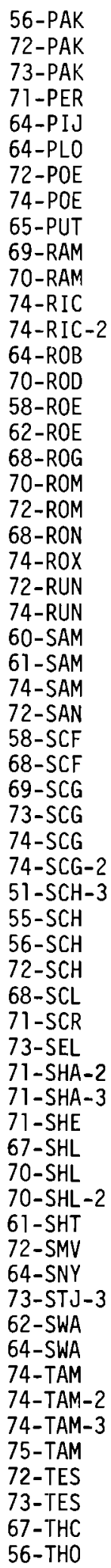 \\
\hline
\end{tabular}


DISPERSAL MODE

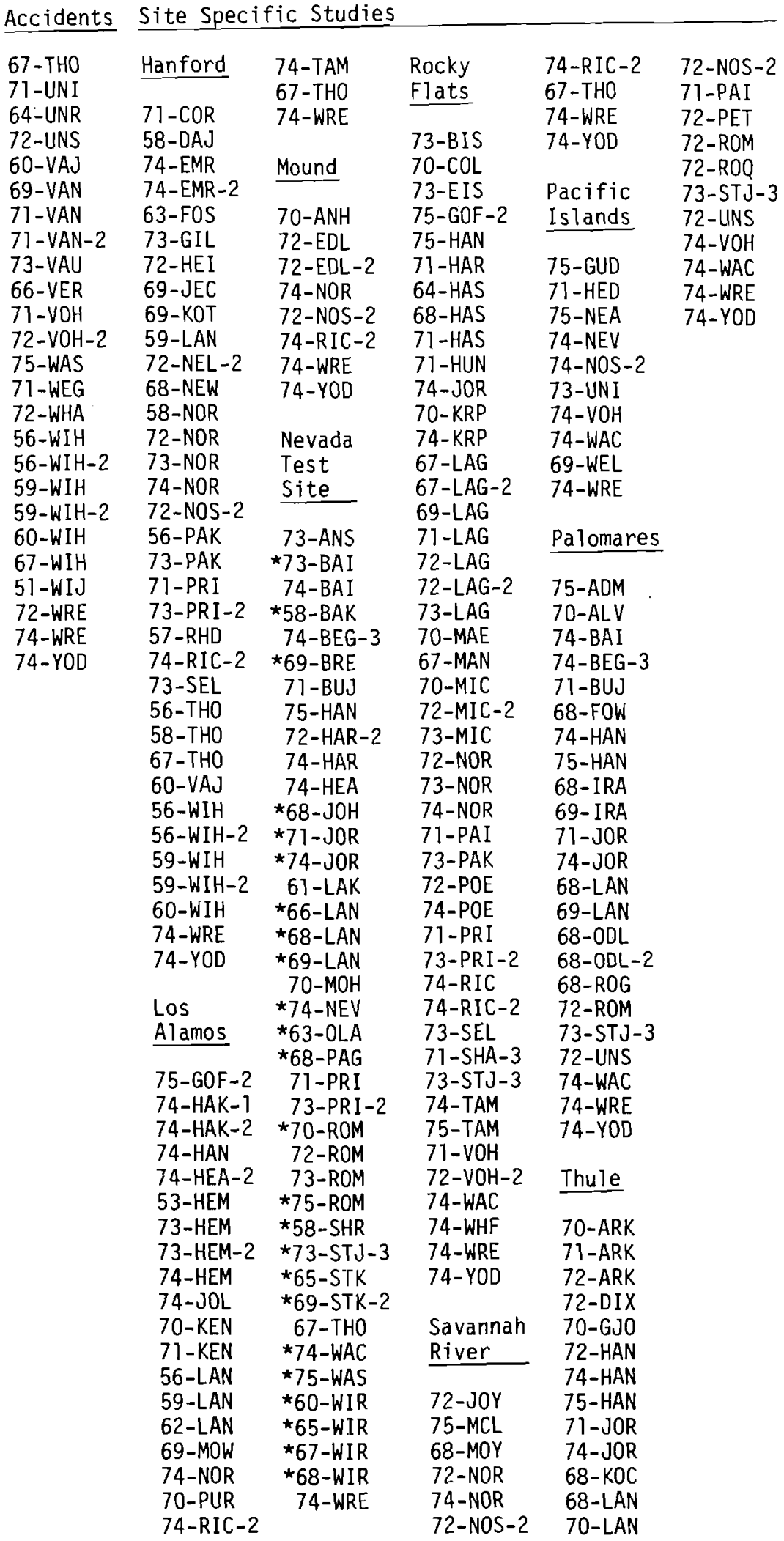

* Includes "safety shot" data 
EXPOSURE MODE

Inhalation or Intratracheal

\begin{tabular}{|c|c|c|c|c|c|c|c|c|}
\hline 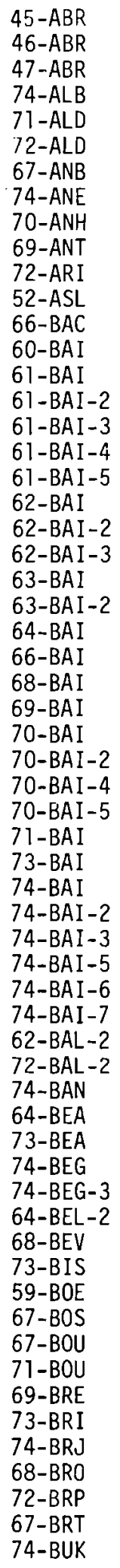 & $\begin{array}{l}69-\mathrm{BUL} \\
70-\mathrm{BUL} \\
71-\mathrm{BUL}-2 \\
72-\mathrm{BUIL} \\
62-\mathrm{BUS} \\
72-\mathrm{BUS} \\
71-\mathrm{CAF} \\
73-\mathrm{CAG} \\
60-\mathrm{CAS} \\
68-\mathrm{CAS} \\
63-\mathrm{CAT} \\
58-\mathrm{CLA} \\
64-\mathrm{CLA} \\
64-\mathrm{CLA}-2 \\
65-\mathrm{CLA} \\
66-\mathrm{CLA} \\
45-\mathrm{COK} \\
45-\mathrm{COK}-2 \\
64-\mathrm{COS} \\
72-\mathrm{CRD} \\
73-\mathrm{CRD} \\
74-\mathrm{CRD} \\
75-\mathrm{CRD} \\
61-\mathrm{DAV} \\
69-\mathrm{DEA} \\
70-\mathrm{DEA} \\
72-\mathrm{IL} \\
58-\mathrm{DOC} \\
59-\mathrm{DOC} \\
74-\mathrm{DOE}-2 \\
64-\mathrm{DOL} \\
71-\mathrm{DOL} \\
72-\mathrm{DOL} \\
72-\mathrm{DOL}-2 \\
74-\mathrm{DOL} \\
65-\mathrm{DOW} \\
72-\mathrm{DOW} \\
72-\mathrm{DUC} \\
74-\mathrm{DUC} \\
71-\mathrm{DUL} \\
64-\mathrm{DUN} \\
71-\mathrm{DUR} \\
72-\mathrm{DUR}-2 \\
73-\mathrm{DUR} \\
74-\mathrm{DUR}-2 \\
64-\mathrm{EAK} \\
64-\mathrm{EHR} \\
73-\mathrm{EIS} \\
64-\mathrm{ERO} \\
69-\mathrm{ERO} \\
71-\mathrm{ERO} \\
64-\mathrm{EVI} \\
71-\mathrm{FAS} \\
74-\mathrm{FIL} \\
74-\mathrm{FIL}-2 \\
72-\mathrm{FIS} \\
55-\mathrm{FOR} \\
58-\mathrm{FOR} \\
60-\mathrm{FOR} \\
60-\mathrm{FOR}-2 \\
62-\mathrm{FOR}-2\end{array}$ & $\begin{array}{l}\text { 63-FOR } \\
65-\mathrm{FUQ} \\
72-\mathrm{GAV} \\
74-\mathrm{GAV} \\
68-\mathrm{GES} \\
68-\mathrm{GES}-2 \\
74-\mathrm{GIL} \\
74-\mathrm{GIL}-2 \\
70-\mathrm{GJO} \\
75-\mathrm{GOF} \\
75-\mathrm{GOF}-2 \\
72-\mathrm{GON} \\
71-\mathrm{HAE} \\
75-\mathrm{HAI} \\
44-\mathrm{HAM} \\
44-\mathrm{HAM}-2 \\
45-\mathrm{HAM} \\
45-\mathrm{HAM}-2 \\
47-\mathrm{HAM} \\
53-\mathrm{HAM} \\
74-\mathrm{HAP} \\
68-\mathrm{HAS} \\
72-\mathrm{HAX} \\
57-\mathrm{HEA} \\
71-\mathrm{HEA} \\
74-\mathrm{HEA} \\
74-\mathrm{HEA}-2 \\
68-\mathrm{HEI} \\
69-\mathrm{HEI} \\
71-\mathrm{HEI} \\
72-\mathrm{HEI} \\
53-\mathrm{HEM} \\
73-\mathrm{HEM} \\
73-\mathrm{HEM}-2 \\
74-\mathrm{HEM} \\
72-\mathrm{HEN} \\
70-\mathrm{HOL} \\
71-\mathrm{HOL} \\
71-\mathrm{HOW} \\
72-\mathrm{HUF} \\
71-\mathrm{HUT} \\
66-\mathrm{INT} \\
68-\mathrm{INT} \\
68-\mathrm{INT}-2 \\
71-\mathrm{INT} \\
72-\mathrm{INT} \\
69-\mathrm{IRA} \\
71-\mathrm{JEA} \\
69-\mathrm{JEC} \\
72-\mathrm{JEC} \\
72-\mathrm{JEW} \\
72-\mathrm{JOL} \\
74-\mathrm{JOR} \\
64-\mathrm{KAL} \\
68-\mathrm{KAL} \\
69-\mathrm{KAL} \\
72-\mathrm{KAL} \\
72-\mathrm{KAL}-2 \\
72-\mathrm{KAL}-3 \\
74-\mathrm{KAN} \\
74-\mathrm{KAO} \\
\text { 70 }\end{array}$ & $\begin{array}{l}73-K A S \\
73-K E C \\
71-K E L \\
71-K E R \\
68-K I E \\
71-K I Y \\
74-K O E \\
68-K O S \\
69-K O S \\
71-K O S \\
71-K O S-2 \\
72-K O S \\
72-K O S-2 \\
72-K O S-3 \\
73-K O S \\
74-K O S \\
69-K O T \\
71-K O T \\
72-K O T \\
62-K R P \\
67-K U D \\
69-K U D \\
72-K U D \\
70-K U N \\
70-K U N-2 \\
70-K U N-3 \\
71-K U N \\
73-L A D \\
74-L A E \\
70-L A F \\
71-L A F \\
74-L A F \\
74-L A F-2 \\
74-L A F-3 \\
65-L A G \\
69-L A G \\
71-L A G \\
72-L A G-2 \\
56-L A N \\
57-L A N \\
59-L A N \\
60-L A N \\
62-L A N \\
64-L A N \\
66-L A N \\
68-L A N \\
69-L A N \\
71-L A N \\
72-L A N \\
74-L A W \\
71-L E V \\
71-L E V-3 \\
72-L E V \\
72-L E V-2 \\
74-L E V \\
64-L I A \\
68-L I A \\
59-L I S \\
71-L O N \\
70-L O W \\
\text { 70-LUT }\end{array}$ & $\begin{array}{l}64-L Y U \\
65-L Y U \\
66-L Y U \\
66-L Y U-2 \\
67-L Y U \\
68-L Y U \\
69-L Y U \\
69-L Y U-3 \\
72-L Y U \\
72-L Y U-2 \\
72-L Y U-3 \\
70-M A E \\
67-M A G \\
68-M A \\
67-M A N \\
71-M A O-2 \\
72-M A O \\
71-M A S \\
71-M A V \\
70-M A Y \\
72-M A Y \\
70-M C O \\
66-M C R \\
72-M C R \\
72-M C R-2 \\
72-M E T \\
74-M E T \\
68-M O E-2 \\
61-M O P \\
67-M O P \\
71-M O R \\
72-M O R \\
73-M O R-3 \\
63-M O S \\
67-M O S-2 \\
69-M O S \\
69-M O S-2 \\
69-M O S-3 \\
71-M O S-2 \\
72-M O S \\
72-M O S-4 \\
73-M O S-3 \\
73-M O S-4 \\
74-M O S-3\end{array}$ & 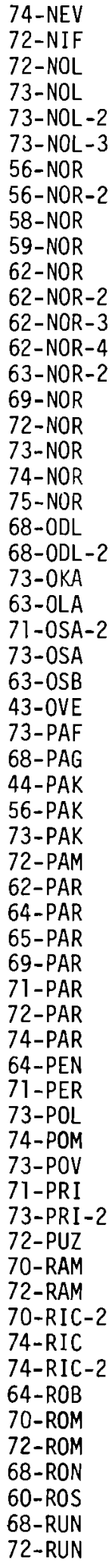 & 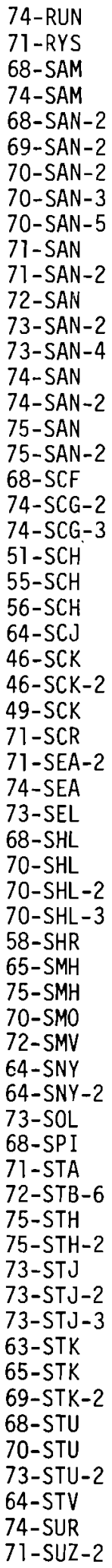 & 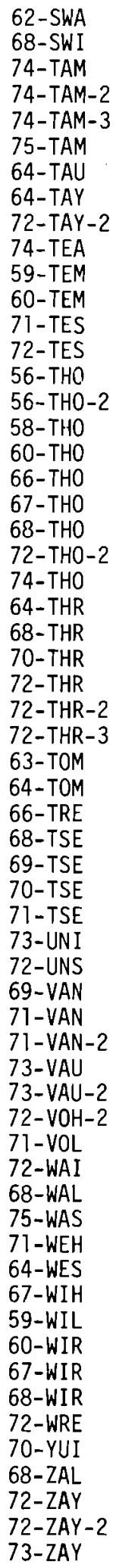 & 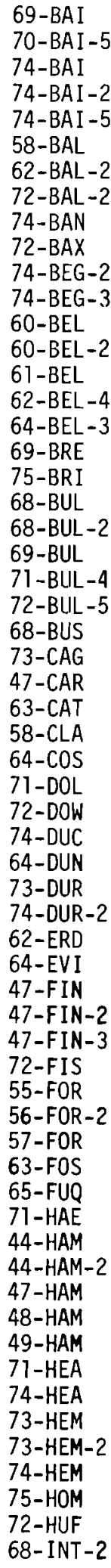 \\
\hline
\end{tabular}


EXPOSURE MODE

Ingestion

\begin{tabular}{|c|c|c|c|c|c|c|c|c|}
\hline 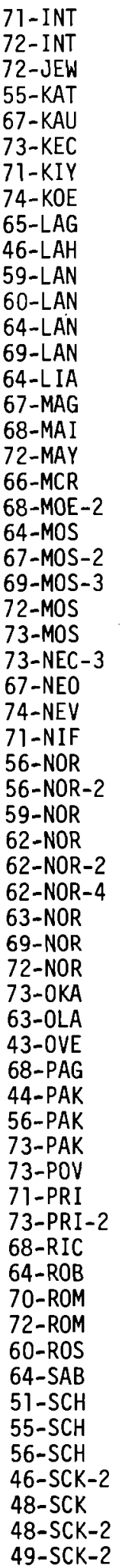 & 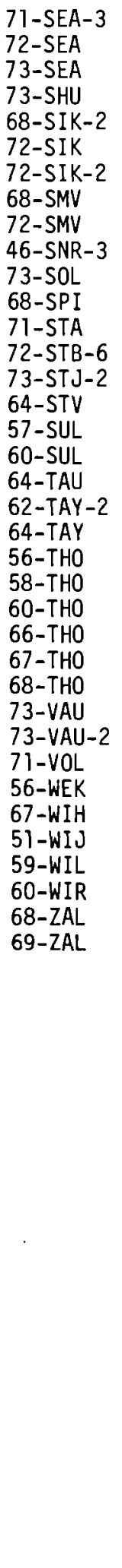 & $\begin{array}{l}52-A S L-2 \\
62-B A I \\
69-B A I \\
70-B A I-5 \\
74-B A I \\
74-B A I-2 \\
74-B A I-5 \\
61-B A L \\
64-B E A \\
73-B E A \\
72-B I S \\
73-B I S \\
69-B L E \\
69-B L E-2 \\
71-B L E \\
48-B L 0 \\
48-B L W \\
45-B R M \\
47-B R M \\
72-B R P \\
67-B U L \\
69-B U L \\
71-B U L-3 \\
72-B U L-2 \\
72-B U L-4 \\
62-B U S \\
62-C A B \\
73-C A G \\
45-C O K \\
45-C O K-2 \\
47-C O P \\
64-C O S \\
73-D A G \\
75-D A G \\
75-D A G-2 \\
48-D E P \\
56-D O B \\
56-D O C \\
58-D O C \\
58-D O C-2 \\
59-D O C \\
71-D O L \\
72-D O L-2 \\
74-D O L \\
65-D O W \\
72-D O W \\
72-D U C \\
74-D U C \\
64-D U N \\
60-D U R \\
61-D U R \\
62-D U R \\
69-D U R \\
71-D U R \\
72-D U R-2 \\
73-D U R \\
74-D U R-2 \\
66-E P S \\
67-E T 0 \\
45-F I D \\
46-F I D \\
\text {-BI }\end{array}$ & 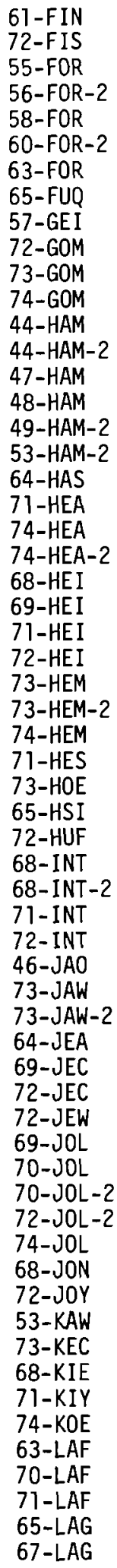 & 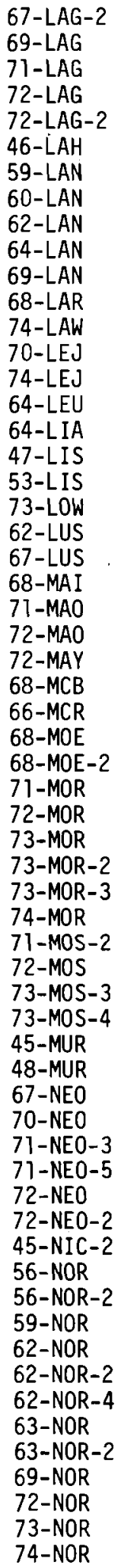 & 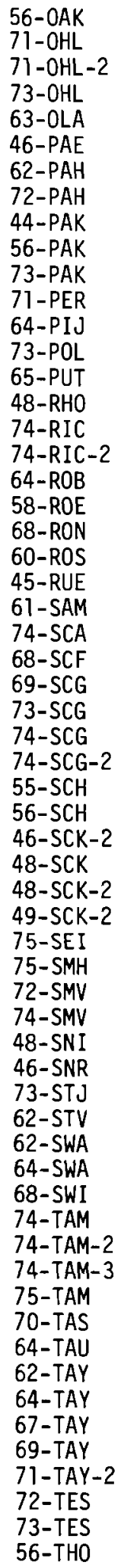 & 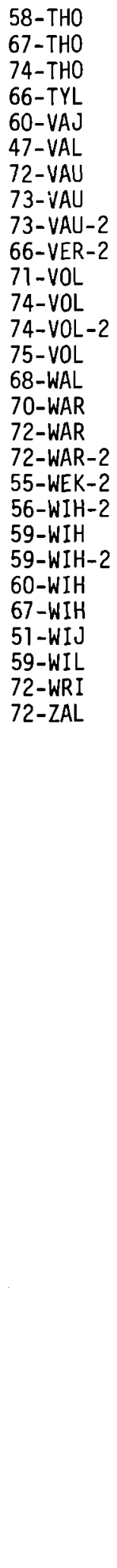 & 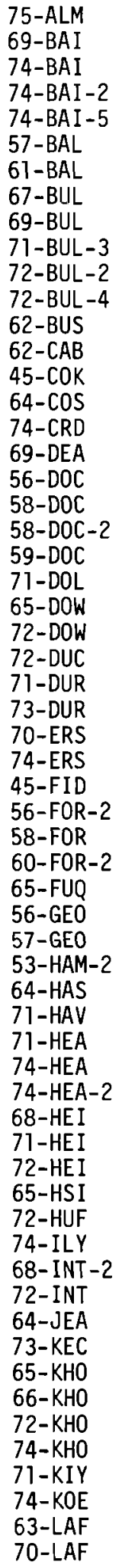 & 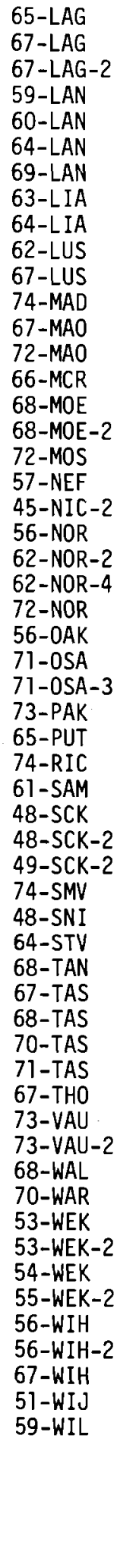 \\
\hline
\end{tabular}

Percutaneous

Intramuscular or Wound

52-ASL - 2

69-LAG

72-LAG

$71-\mathrm{OHL}-2$

74-THO

66-TYL

72-VAU

73-VAU-2

74-VOL-2

75-VOL

68-WAL

72-WAR-2

55-WEK-2

-WETH-2

59-WIH-2

60-WIH

67-WIH

72-WRI

71-DUR

74-ERS

$56-F O R$

58-FOR

71-HEA

74-HEA-2

72-HEI

$74-$ ILY

73-KEC

65-KHO

66-KHO

71-KIY

63-LAF

70-LAF 
Repeated

\begin{tabular}{|c|c|}
\hline $\begin{array}{l}73-A T K \\
66-B E A \\
73-B E A \\
74-B E G \\
65-B E N \\
61-B 0 G \\
62-B O G \\
63-B 0 G \\
74-B R J \\
72-B R P \\
61-B U L \\
68-B U L-2 \\
69-B U L\end{array}$ & $\begin{array}{l}62-\text { RYS } \\
62-\mathrm{RYS} \\
71-\mathrm{RYS} \\
60-\text { SAM } \\
69-\text { TAY } \\
74-\text {-TEA } \\
67-\text { THO } \\
74-\text { THO } \\
66-\text { TRU } \\
67-\text { VAU } \\
\text { 73-VAU } \\
\text { 56-WEK } \\
\text { 72-ZAL }\end{array}$ \\
\hline
\end{tabular}

69-BUL-2

71-BUL -4

72-BUL-3

72-BUL-5

72-BUS

73-CAG

63-CAT

72-DRM

73-FAB

70-FAI

70-FAI - 2

73-FRC

68-INT-2

71-INT

68-KAL

69-KAL

55-KAT

69-KOT

69-KUD

56-LAN

57-LAN

59-LAN

62-LAN

64-LAN

66-LEM

74-LEV-2

75-LEV

64-LYU-2

66-LYU

68-LYU

69-LYU

69-LYU-2

69-LYU-3

72-LYU

72-MAY

61-MOS

63-MOS

65-MOS-2

65-MOS-3

69-MOS-3

73-MOS-2

74-MOS-4

72-MYE

$71-\mathrm{NIF}$

74-POM

68-RIC

60-RYS

61-RYS 
EXPERIMENTAL ANIMAL

Dog

\begin{tabular}{|c|c|c|c|c|c|c|c|c|}
\hline $\begin{array}{l}59-A R N \\
62-A R N \\
72-A T H \\
64-B A D \\
60-B A I \\
61-B A I-2 \\
61-B A I-3 \\
61-B A I-4 \\
62-B A I \\
62-B A I-3 \\
63-B A I \\
63-B A I-2 \\
64-B A I \\
66-B A I \\
68-B A I \\
69-B A I \\
70-B A I \\
70-B A I-2 \\
70-B A I-4 \\
70-B A I-5 \\
71-B A I \\
73-B A I \\
74-B A I \\
74-B A I-2 \\
74-B A I-3 \\
74-B A I-4 \\
74-B A I-5 \\
74-B A I-6 \\
74-B A I-7 \\
72-B A L-2 \\
45-B A R \\
73-B A X \\
73-B A X-2 \\
66-B E A \\
62-B E D \\
69-B E D \\
72-B I S \\
73-B I S \\
68-B L A \\
72-B L A \\
61-B 0 G \\
62-B O G \\
63-B 0 G \\
45-B R M \\
69-B R U \\
69-B R U-2 \\
71-B R U \\
72-B R U \\
69-B U K \\
69-B U L \\
72-B U L \\
72-B U S \\
73-C A G \\
68-C A S \\
63-C A T \\
62-C H R \\
72-C H R \\
64-C L A \\
64-C L A-2 \\
65-C L A \\
66-C L A \\
\text {-BA }\end{array}$ & $\begin{array}{l}62-\mathrm{COH} \\
45-\mathrm{COK} \\
45-\mathrm{COK}-2 \\
72-\mathrm{CRD} \\
73-\mathrm{CRD} \\
73-\mathrm{DAG} \\
75-\mathrm{DAG} \\
75-\mathrm{DAG}-2 \\
72-\mathrm{DIL} \\
55-\mathrm{DOJ} \\
62-\mathrm{DOJ} \\
69-\mathrm{DOJ} \\
70-\mathrm{DOJ} \\
71-\mathrm{DOJ} \\
72-\mathrm{DOJ} \\
64-\mathrm{DOL} \\
71-\mathrm{DOL} \\
72-\mathrm{DOL} \\
73-\mathrm{DOL} \\
74-\mathrm{DOL} \\
62-\mathrm{DOT} \\
62-\mathrm{DOT}-2 \\
62-\mathrm{DOT}-3 \\
69-\mathrm{DOT} \\
71-\mathrm{DUR} \\
72-\mathrm{DUR}-2 \\
73-\mathrm{DUR} \\
74-\mathrm{DUR}-2 \\
68-\mathrm{ELI} \\
62-\mathrm{ELK}-2 \\
63-\mathrm{ELK} \\
71-\mathrm{ELK} \\
60-\mathrm{ERL} \\
45-\mathrm{FID} \\
61-\mathrm{FIN} \\
72-\mathrm{FIS} \\
72-\mathrm{GAV} \\
74-\mathrm{GAV} \\
74-\mathrm{GIL} \\
70-\mathrm{GJ0} \\
75-\mathrm{GOF} \\
75-\mathrm{GOF}-2 \\
62-\mathrm{GOL} \\
72-\mathrm{GOM} \\
73-\mathrm{GOM} \\
74-\mathrm{GOM} \\
71-\mathrm{GRI} \\
74-\mathrm{HEA} \\
62-\mathrm{HER} \\
71-\mathrm{HOW} \\
71-\mathrm{HUT} \\
66-\mathrm{INT} \\
68-\mathrm{INT} \\
72-\mathrm{INT} \\
72-\mathrm{JAM} \\
60-\mathrm{JEW} \\
60-\mathrm{JEW}-2 \\
61-\mathrm{JEW} \\
62-\mathrm{JEW} \\
62-\mathrm{JEW}-3 \\
62-\mathrm{JEW}-4\end{array}$ & 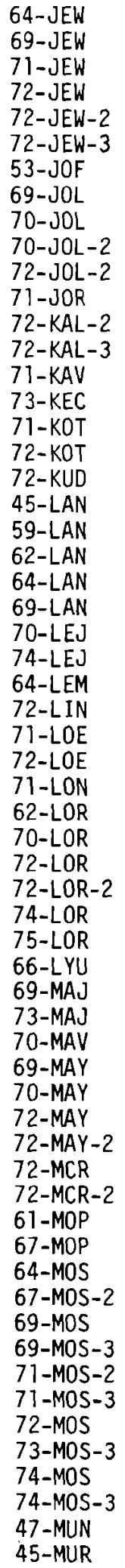 & $\begin{array}{l}\text { 72-NAB } \\
75-N A B \\
61-N A T \\
72-N I F \\
69-N O M \\
56-N O R \\
59-N O R \\
62-N O R-2 \\
72-N O R \\
63-O L A \\
46-P A E \\
62-P A R \\
64-P A R \\
65-P A R \\
69-P A R \\
71-P A R \\
72-P A R \\
74-P A R \\
72-P A Z \\
72-P E S-2 \\
47-P R 0 \\
49-P R O \\
62-R E H \\
68-R I C \\
64-R O B \\
69-R O L \\
56-\text { ROS-2 } \\
60-R O S \\
72-R U D-2 \\
74-R U D \\
45-R U E \\
51-R U E \\
65-R U H \\
60-R Y S \\
61-R Y S \\
62-R Y S \\
62-R Y S-2 \\
69-S A G \\
68-S A M \\
70-S A N-3 \\
71-S A N-2 \\
72-S A N \\
74-S C A \\
74-S C G-2 \\
47-S C H \\
49-S C H \\
55-S C H \\
56-S C H \\
72-S I K \\
72-S M V \\
64-S N Y-2 \\
71-S P I \\
71-S T A \\
59-S T B \\
59-S T B-2 \\
62-S T B \\
62-S T B-2 \\
63-S T B \\
68-S T B \\
68-S T B-2 \\
69-S T B \\
\text {-NB }\end{array}$ & 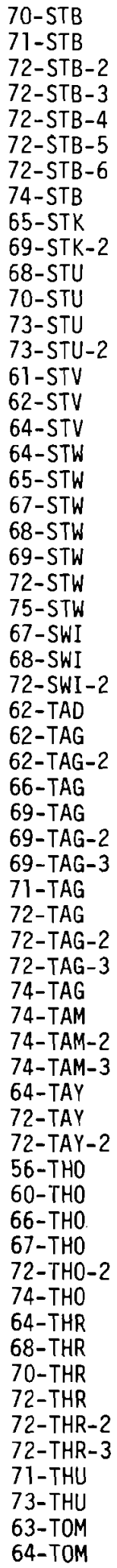 & 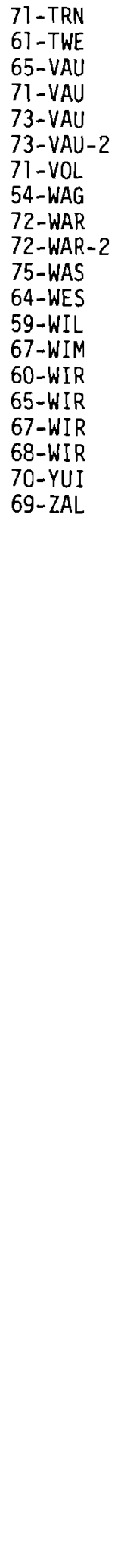 & $\begin{array}{l}\text { 73-ADE } \\
\text { 74-ANE } \\
\text { 73-ATK } \\
\text { 74-BAI-3 } \\
\text { 74-BAI-5 } \\
\text { 71-BRA } \\
\text { 72-BRA } \\
\text { 74-BRA } \\
\text { 70-BUC } \\
\text { 73-BUC } \\
\text { 73-DUR } \\
\text { 72-HAZ } \\
\text { 72-HAZ-2 } \\
\text { 74-HAZ } \\
\text { 72-INT } \\
\text { 72-MCK } \\
\text { 72-MCR } \\
\text { 71-MEW-3 } \\
\text { 72-MEW } \\
\text { 73-NIA } \\
\text { 74-SEI } \\
\text { 75-SEI -2 } \\
\text { 74-TAM-3 } \\
\text { 75-TAM } \\
\text { 74-VOL-3 }\end{array}$ & 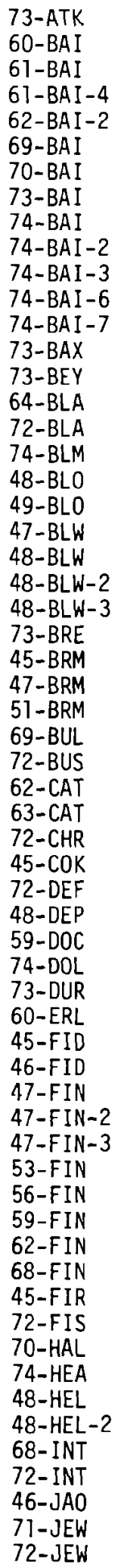 & 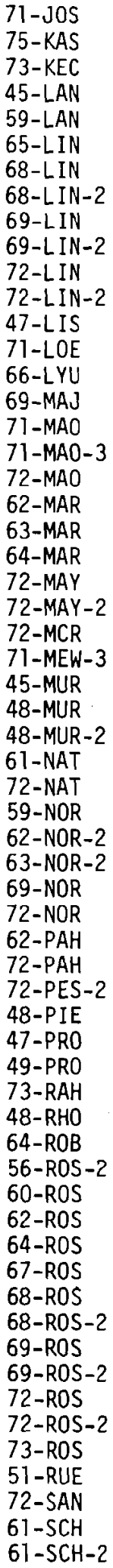 \\
\hline
\end{tabular}

Hamster Mouse 
EXPERIMENTAL ANIMAL

\begin{tabular}{|c|c|c|c|c|c|c|c|c|}
\hline ouse & Primate & Rabbit & & at & & & & \\
\hline 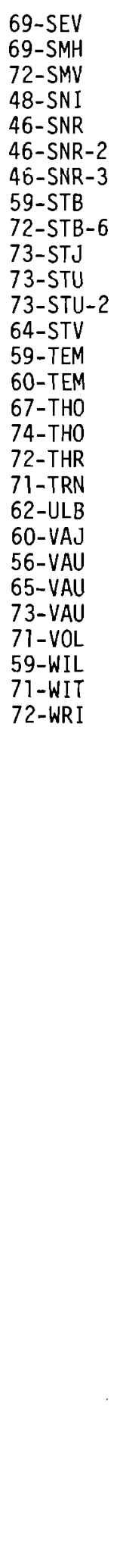 & 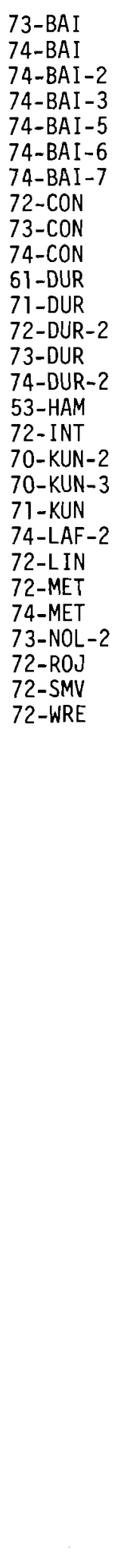 & 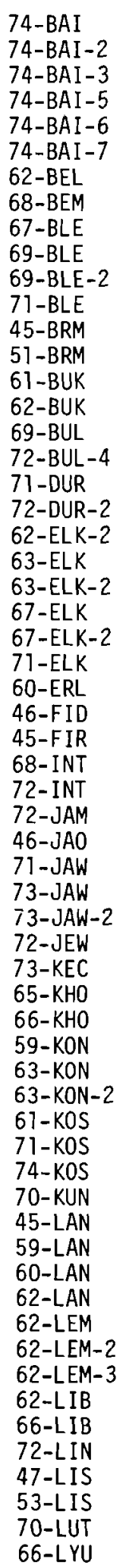 & 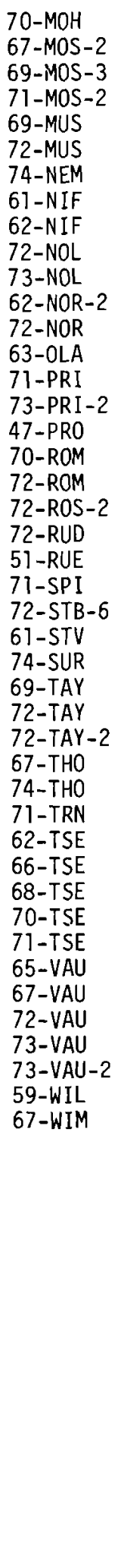 & $\begin{array}{l}45-A B R \\
46-A B R \\
47-A B R \\
68-A \cap E \\
74-A L B \\
74-A N E \\
69-A N T \\
72-A R I \\
51-A R N \\
51-A R N-2 \\
56-A R N \\
57-A R N \\
52-A S L \\
52-A S L-2 \\
60-B A I \\
61-B A I-5 \\
63-B A I 2 \\
69-B A I \\
70-B A I \\
70-B A I-2 \\
70-B A I-5 \\
71-B A I \\
73-B A I \\
74-B A I \\
74-B A I-2 \\
74-B A I-3 \\
74-B A I-5 \\
74-B A I-6 \\
74-B A I-7 \\
57-B A L \\
58-B A L \\
61-B A L \\
62-B A L \\
62-B A L-2 \\
62-B A L-3 \\
62-B A L-4 \\
64-B A L \\
66-B A L \\
67-B A L \\
72-B A L \\
45-B A R-2 \\
72-B A X \\
70-B E J \\
59-B E L \\
60-B E L \\
60-B E L-2 \\
61-B E L \\
62-B E L-2 \\
62-B E L-3 \\
62-B E L-4 \\
62-B E L-5 \\
64-B E L \\
64-B E L-2 \\
64-B E L-3 \\
69-B E L \\
65-B E N \\
69-B E N \\
73-B I S \\
64-B L A \\
68-B L A \\
48-B L 0 \\
\text {-Bi }\end{array}$ & 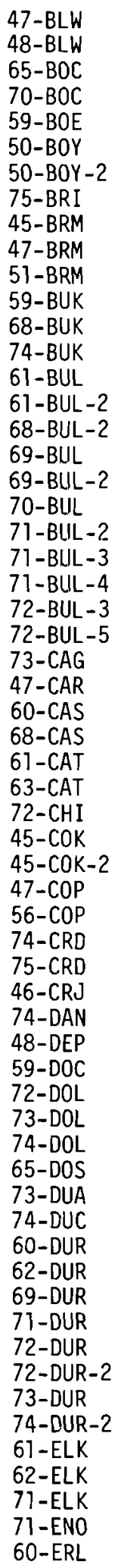 & 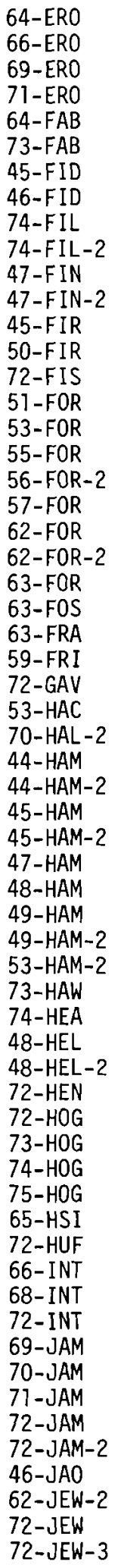 & 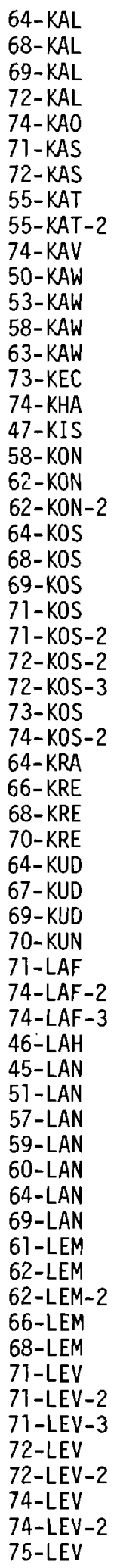 & $\begin{array}{l}62-L I B-2 \\
74-L I K \\
60-L I N \\
62-L I N \\
72-L I N \\
47-L I S \\
53-L I S \\
59-L I S \\
59-L I T \\
68-L O G \\
71-L Y A \\
73-L Y A \\
64-L Y U \\
64-L Y U-2 \\
65-L Y U \\
66-L Y U \\
66-L Y U-2 \\
67-L Y U \\
68-L Y U \\
69-L Y U \\
69-L Y U-2 \\
69-L Y U-3 \\
72-L Y U \\
72-L Y U-2 \\
72-L Y U-3 \\
65-M A H \\
66-M A H \\
67-M A H \\
69-M A H \\
69-M A H-2 \\
71-M A H \\
74-M A H \\
71-M A O-2 \\
72-M A 0 \\
64-M A R \\
71-M A S \\
72-M A Y \\
68-M C B \\
72-M C R \\
71-M E W \\
71-M E W-2 \\
71-M E W-3 \\
72-M E W \\
70-M O H \\
71-M O R \\
72-M O R \\
72-M O R-2 \\
73-M O R \\
73-M O R-2 \\
73-M O R-3 \\
73-M O R-4 \\
74-M O R \\
61-M O S \\
62-M O S \\
63-M O S \\
65-M O S \\
65-M O S-2 \\
65-M O S-3 \\
66-M O S-2 \\
66-M O S-3 \\
67-M O S-2\end{array}$ \\
\hline
\end{tabular}


EXPERIMENTAL ANIMAL

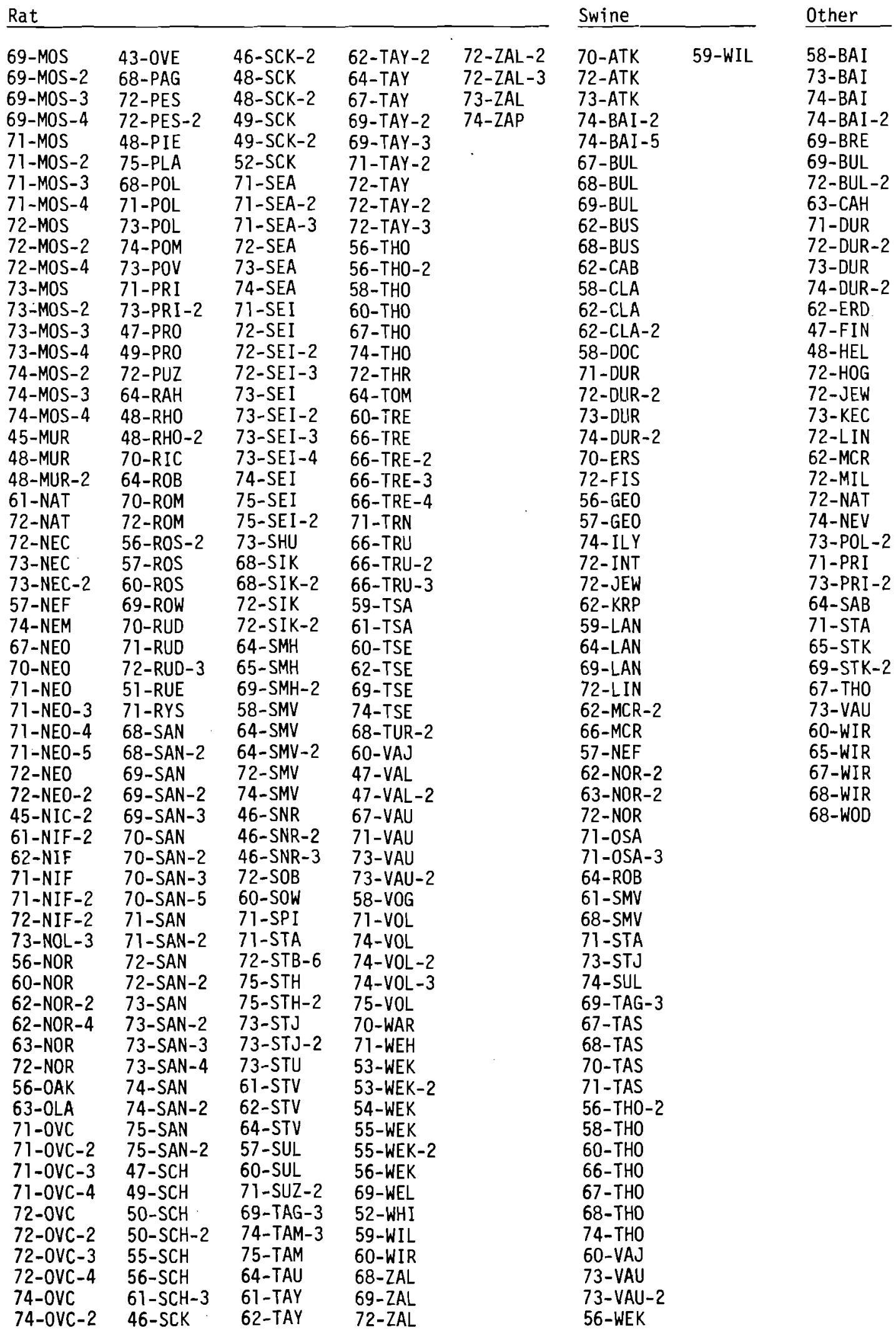


ORGANS, TISSUES, SECRETIONS

Adrenals

\begin{tabular}{|c|c|}
\hline 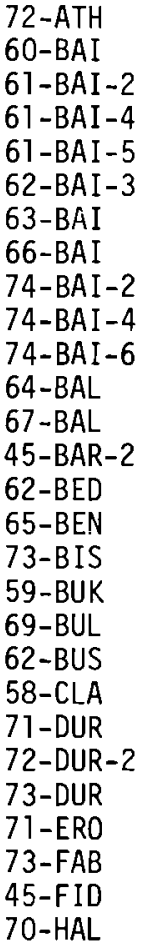 & 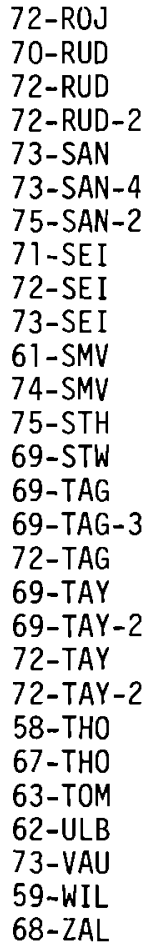 \\
\hline
\end{tabular}

70-HAL-2

72-INT

53-JOF

70-JOL-2

$72-\mathrm{JOL}-2$

64-KOS

66-KRE

74-LEJ

64-LEM

66-LEM

71-LEV-2

7]-LEV-3

70-LOR

74-LOR

69-LYU

72-LYU

72-LYU-2

72-LYU-3

69-MAH'-2

72-MAO

67-MOP

66-MOS-3

69-MOS-2

69-MOS-3

72-MOS-4

74-MOS

74-MOS-2

61-NIF-2

73-NOR

74-NOR

$75-N O R$

69-PAR

48-RHO-2
Blood

\section{6-ABR}

64-BAD

60-BAI

61-BAI-2

61-BAI-3

61-BAI-4

62-BAI-3

63-BAI

66-BAI

68-BAI

70-BAI

70-BAI -4

71-BAI

73-BAI

74-BAI

74-BAI - 2

74-BAI -3

74-BAI -4

74-BAI-5

74-BAI-6

62-BAL

67-BAL

72-BAL

72-BAL-2

45-BAR

73-BAX-2

69-BED

74-BEG

59-BEL

61-BEL

62-BEL-2

62-BEL-4

62-BEL-5

69-BEL

65-BEN

73-BEY

73-BIS

67-BLE

65-BOC

66-BOC

61-BOG

62-BOG

63-BOG

50-BOY

50-BOY-2

47-BRM

69-BRU

69-BRU-2

59-BUK

61-BUIK

62-BUK

69-BUK

61-BUL-2

69-BUL

69-BUL-2

70-BUL

71-BUL-2

71-BUL-3

71-BUL-4

72-BUL

72-BUL-4
$62-B U S$

63-CAH

63-CAT

68-CHI

70-CHI

72-CH I

58-CLA

45-COK

45-COK-2

72-CON

73-CON

74-CON

46-CRJ

72-DIL

55-DOJ

62-DOJ

69--D0J

70-DOJ

71-DOJ

72-DOJ

71-DOL

72-DOL

72-DOL-2

62-D0T

73-DUA

62-DUR

71-DUR

72-DUR

72-DUR-2

73-DUR

74-DUR-2

62-ELK-2

63-ELK

67-ELK-2

71 -ELK

64-ERO

66-ERO

71-ERO

73-FAB

45-FID

62-F IN

50-FIR

72-FIS

58-FOR

59-FRI

72-GAV

62-GOL

70-HAL

70-HAL-2

53-HAM-2

73-HAW

57-HEA

71-HES

75-HOG

66-INT

72-INT

71-JAM

46-JAO

49-JAO

73-JAW-2
71-JEA

62-JEW

$62-J E W-3$

62-JEW-4

69-JEW

71-JEW

72-JEW

72-JEW-3

53-JOF

70-JOL-2

64-KAL

68-KAL

69-KAL

72-KAS

75-KAS

71-KAV

63-KAW

73-KEC

65-KHO

66-KHO

71-KIY

74-KOE

64-KOS

72-KOS-2

73-KOS

66-KRE

70-KRE

64-KUID

67-KUID

69-KLID

73-LAD

63-LAF

71-LAF

65-LAG

67-LAG

67-LAG-2

45-LAN

59-LAN

69-LAN

68-LAR

74-LEJ

61-LEM

62-LEM-3

71-LEV-2

71-LEV-3

63-LIA

62-LIB

74-LIK

60-LIN

62-LIN

72-LIN

64-LYU

69-MAJ

73-MAJ

67-MAN

71-MAO

7]-MAO-3

72-MAO

68-MAP

72-MAY-2
62-MCR

71-MEW

67-MOP

72-MOR

73-MOR

73-MOR-2

74-MOR

62-MOS

65-MOS

65-MOS-2

65-MOS-3

66-MOS-2

66-MOS-3

69-MOS-2

69-MOS-3

72-MOS

72-MOS-4

47-MUN

69-MUS

72-NAB

72-NEC

73-NEC

73-NEC-2

73-NEC-3

68-NEL

69-NEL

67-NEO

71-NEO-3

71 -NEO-5

72-NEO

74-NEV

45-NIC-2

61-NIF

6]-NIF-2

62-NIF

71-NIF-2

69-NOM

58-NOR

74-NOR

75-NOR

71-OHL

73-OHL

46-PAE

73-PAK

69-PAR

72-PAZ

64-PIJ

68-POL

73-POL

73-POL-2

64-ROB

72-ROJ

56-ROS-2

57-ROS

60-ROS

64-ROS

72-ROS-2

72-RUD-2

45-RUE

51-RUE

65-RUH

$\begin{array}{ll}\text { 62-RYS } & \text { 73-VAU-2 } \\ \text { 73-SAN-3 } & 66-\text { VER } \\ \text { 68-SCF } & 71-\text { VOL } \\ \text { 74-SCG } & 54-\text { WAG } \\ 49-\text { SCH } & 70 \text {-WAR } \\ 50-S C H & 72 \text {-WAR } \\ 50-S C H-2 & 56 \text {-WEK }\end{array}$

51-SCH 64-WES

55-SCH 52-WHI

$61-\mathrm{SCH}$

46-SCK

48-SCK

48-SCK-2

49-SCK 
ORGANS, TISSUES, SECRETIONS

Bone

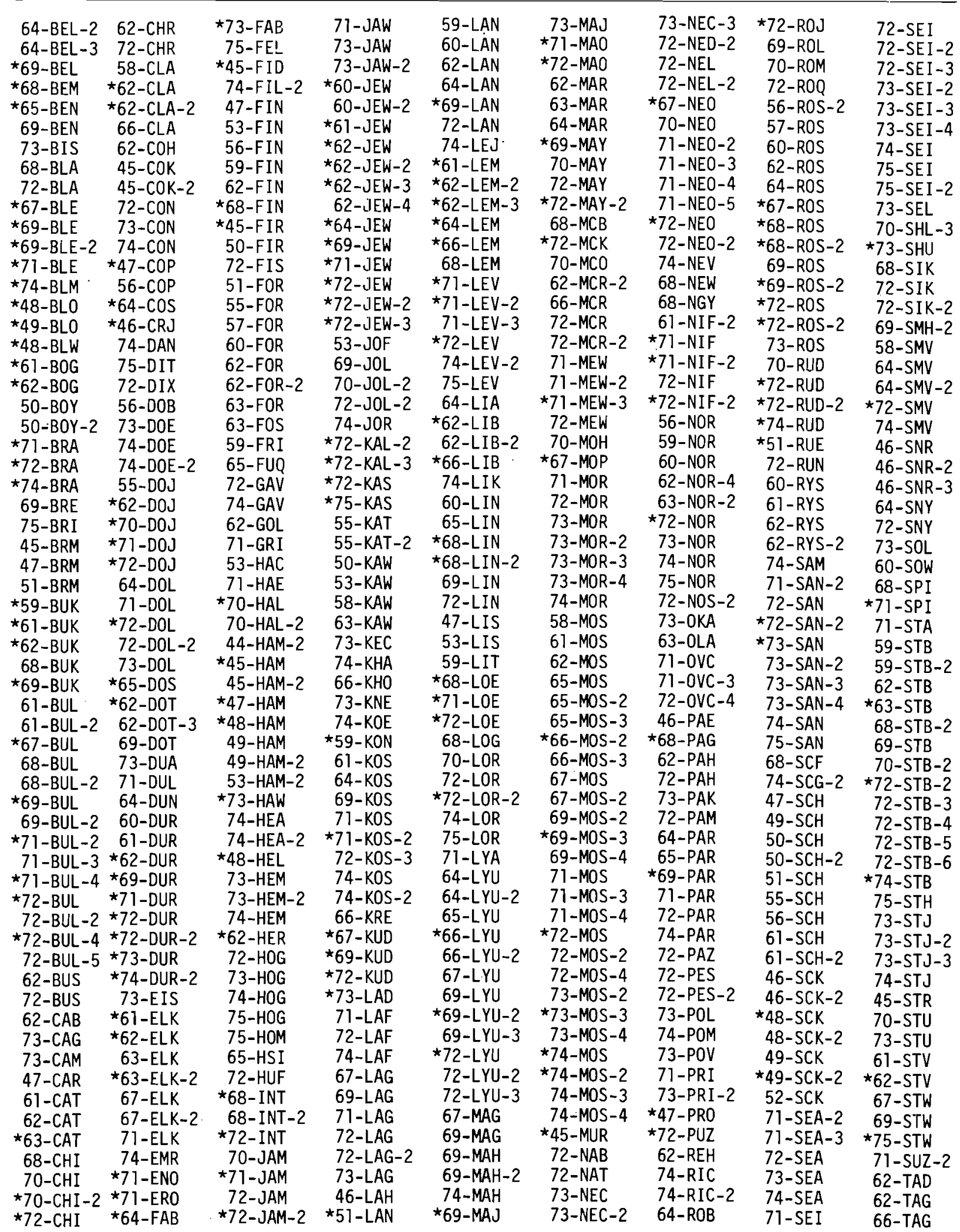




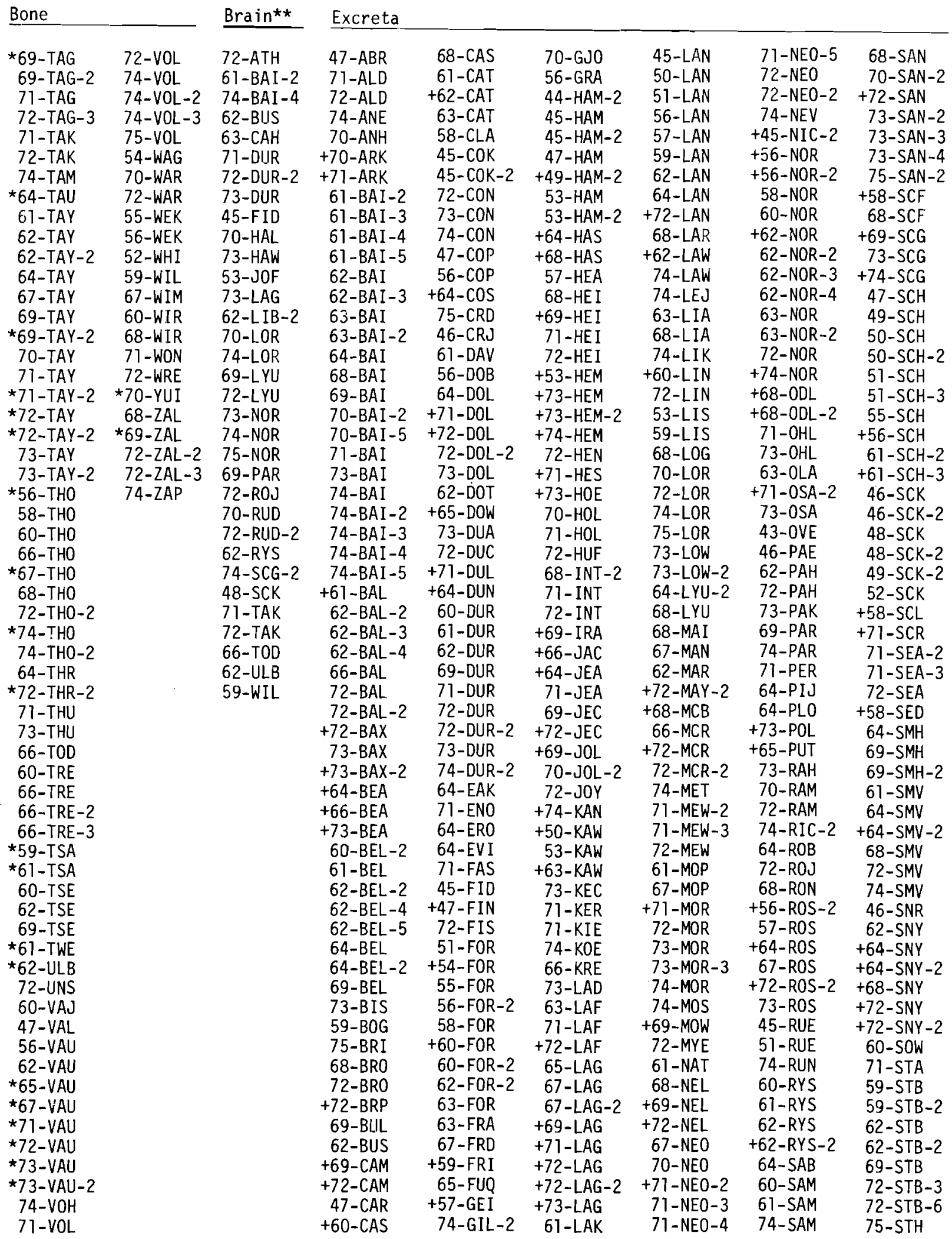


ORGANS, TISSUES, SECRETIONS

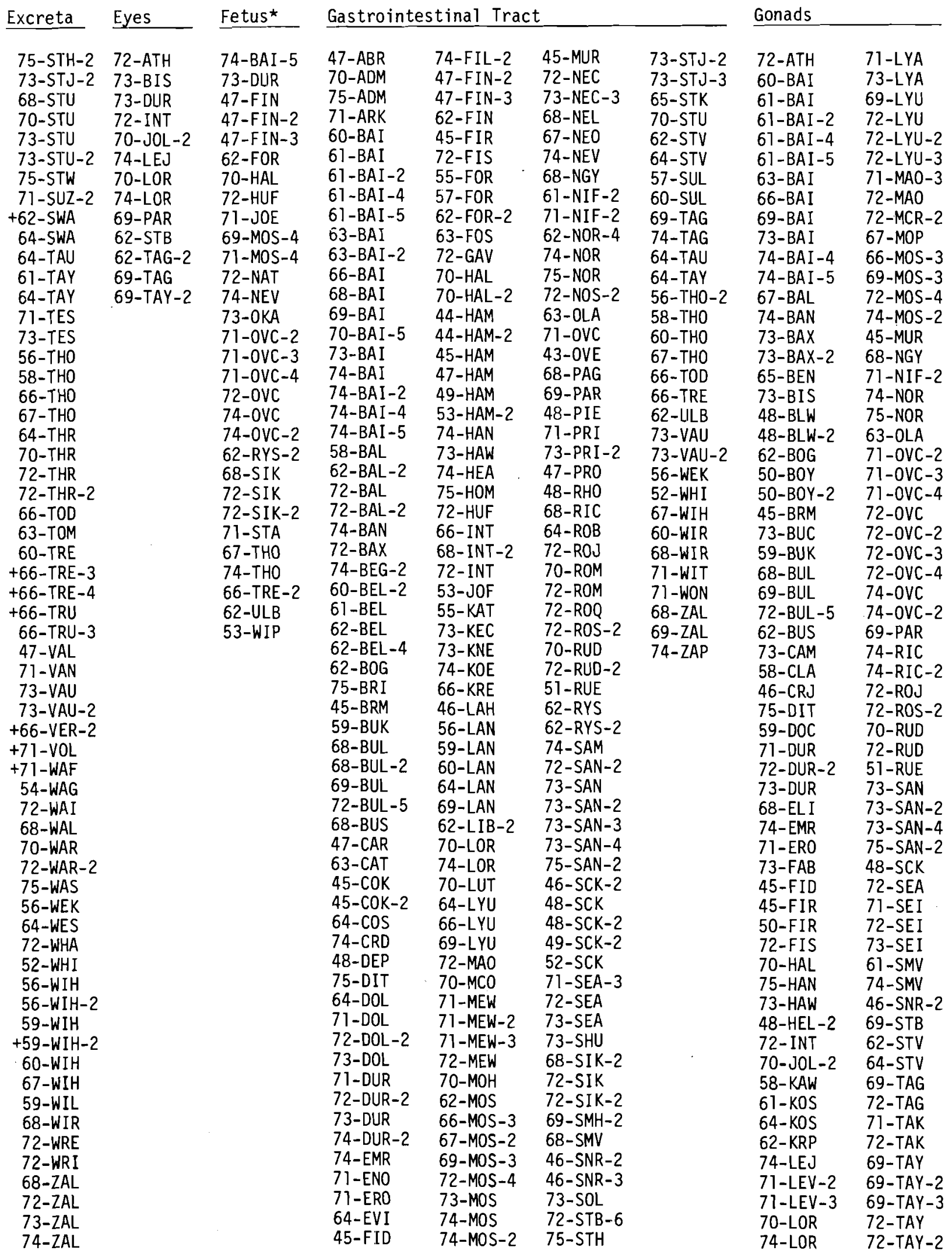




\begin{tabular}{|c|c|c|c|c|c|c|c|c|}
\hline Gonads & Hair & Heart & Kidney & & & & & Liver \\
\hline $\begin{array}{l}\text { 58-THO } \\
67-\text { THO } \\
74-\text { THO } \\
74-\text { THO-2 } \\
62-\text { ULB } \\
65 \text {-VAU } \\
73-\text { VAU } \\
58-V O G \\
59-\text { WIL } \\
68-\text { ZAL }\end{array}$ & $\begin{array}{l}45-\mathrm{BRM} \\
71-\mathrm{JAW} \\
73-\mathrm{JAW} \\
73-\mathrm{JAW}-2 \\
74-\mathrm{KOE} \\
62-\mathrm{ULB} \\
55-W E K-2\end{array}$ & 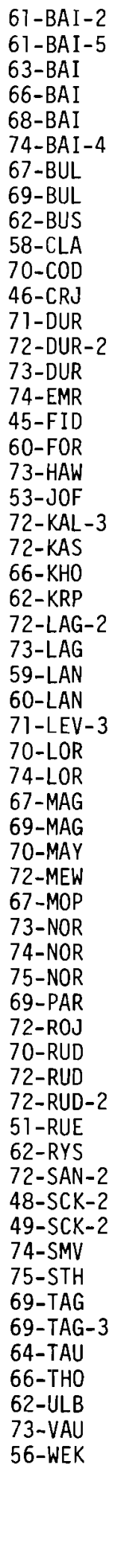 & $\begin{array}{l}\text { 47-ABR } \\
72-\mathrm{ATH} \\
60-\mathrm{BAH} \\
61-\mathrm{BAI} \\
61-\mathrm{BAI}-2 \\
61-\mathrm{BAI}-4 \\
61-\mathrm{BAI}-5 \\
62-\mathrm{BAI} \\
62-\mathrm{BAI}-3 \\
63-\mathrm{BAI} \\
63-\mathrm{BAI}-2 \\
66-\mathrm{BAI} \\
68-\mathrm{BAI} \\
69-\mathrm{BAI} \\
70-\mathrm{BAI}-2 \\
70-\mathrm{BAI}-5 \\
71-\mathrm{BAI} \\
73-\mathrm{BAI} \\
74-\mathrm{BAI}-2 \\
74-\mathrm{BAI}-3 \\
74-\mathrm{BAI}-4 \\
74-\mathrm{BAI}-5 \\
74-\mathrm{BAI}-6 \\
74-\mathrm{BAI}-7 \\
62-\mathrm{BAL} \\
62-\mathrm{BAL}-2 \\
67-\mathrm{BAL} \\
74-\mathrm{BAN} \\
45-\mathrm{BAR}-2 \\
73-\mathrm{BAX} \\
73-\mathrm{BAX}-2 \\
74-\mathrm{BEG} \\
74-\mathrm{BEG}-3 \\
61-\mathrm{BEL} \\
62-\mathrm{BEL} \\
62-\mathrm{BEL}-2 \\
62-\mathrm{BEL}-5 \\
64-\mathrm{BEL} \\
64-\mathrm{BEL}-2 \\
64-\mathrm{BEL}-3 \\
69-\mathrm{BEL} \\
73-\mathrm{BIS} \\
48-\mathrm{BLW} \\
48-\mathrm{BLW}-3 \\
50-\mathrm{BOY} \\
50-\mathrm{BOY}-2 \\
45-\mathrm{BRM} \\
72-\mathrm{BRU} \\
59-\mathrm{BUU} \\
67-\mathrm{BUL} \\
68-\mathrm{BUL} \\
68-\mathrm{BUL}-2 \\
69-\mathrm{BUL} \\
71-\mathrm{BUL}-4 \\
72-\mathrm{BUL}-3 \\
72-\mathrm{BUL}-4 \\
72-\mathrm{BUL}-5 \\
62-\mathrm{BUS} \\
62-\mathrm{CAB} \\
63-\mathrm{CAH} \\
73-\mathrm{CAM} \\
47-\mathrm{CAR}\end{array}$ & 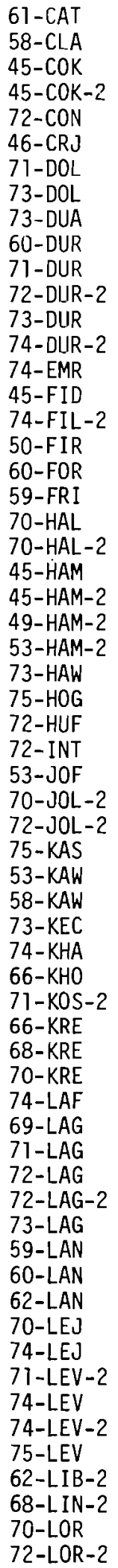 & 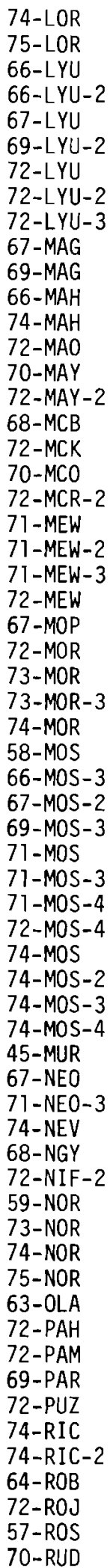 & 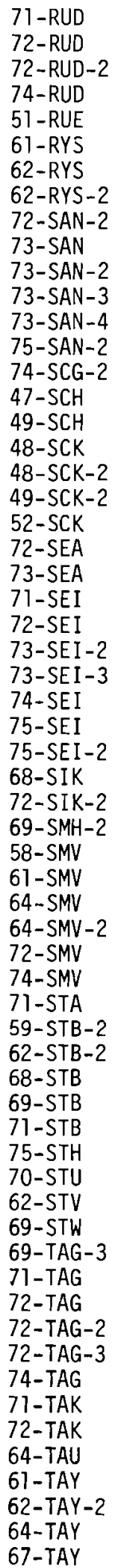 & $\begin{array}{l}69-\text { TAY } \\
58-T H 0 \\
66-\text { THO } \\
67-\text { THO } \\
64-\text { THR } \\
72-\text { THR-2 } \\
66-\text { TOD } \\
63-\text { TOM } \\
60-\text { TRE } \\
69-\text { TSE } \\
62-\text { ULB } \\
73-\text { VAU } \\
73-\text { VAU-2 } \\
74-\text { VOL-3 } \\
75-\text { VOL } \\
72-\text { WAR } \\
56-\text { WEK } \\
52-\text { WHI } \\
59-\text { WIL } \\
68-\text { WIR } \\
72-\text { WRI } \\
68-\text { ZAL } \\
69-\text { ZAL } \\
72-\text { ZAL-2 } \\
72-\text { ZAL-3 }\end{array}$ & 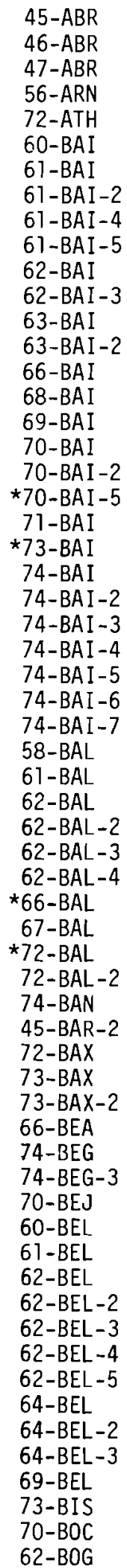 \\
\hline
\end{tabular}


ORGANS, TISSUES, SECRETIONS

Liver

\begin{tabular}{|c|c|c|c|c|c|c|c|c|}
\hline $\begin{array}{l}67-\mathrm{BOS} \\
50-\mathrm{BOY} \\
50-\mathrm{BOY}-2 \\
71-\mathrm{BRA} \\
72-\mathrm{BRA} \\
74-\mathrm{BRA} \\
69-\mathrm{BRE} \\
75-\mathrm{BRI} \\
45-\mathrm{BRM} \\
47-\mathrm{BRM} \\
71-\mathrm{BRU} \\
72-\mathrm{BRU} \\
59-\mathrm{BUK} \\
62-\mathrm{BUK} \\
68-\mathrm{BUK} \\
69-\mathrm{BUK} \\
61-\mathrm{BUL} \\
67-\mathrm{BUL} \\
68-\mathrm{BUL} \\
68-\mathrm{BUL}-2 \\
669-\mathrm{BUL} \\
71-\mathrm{BUIL}-4 \\
72-\mathrm{BLIL} \\
72-\mathrm{BUL}-2 \\
72-\mathrm{BLIL}-3 \\
72-\mathrm{BUL}-4 \\
72-\mathrm{BUL}-5 \\
62-\mathrm{BUS} \\
72-\mathrm{BUS} \\
62-\mathrm{CAB} \\
73-\mathrm{CAG} \\
63-\mathrm{CAH} \\
73-\mathrm{CAM} \\
47-\mathrm{CAR} \\
61-\mathrm{CAT} \\
62-\mathrm{CAT} \\
\text { *63-CAT } \\
58-\mathrm{CLA} \\
66-\mathrm{CLA} \\
62-\mathrm{COH} \\
45-\mathrm{COK} \\
45-\mathrm{COK}-2 \\
72-\mathrm{CON} \\
73-\mathrm{CON} \\
\text { *74-CON } \\
47-\mathrm{COP} \\
56-\mathrm{COP} \\
64-\mathrm{COS} \\
46-\mathrm{CRJ} \\
74-\mathrm{DAN} \\
75-\mathrm{DIT} \\
72-\mathrm{DIX} \\
56-\mathrm{DOB} \\
73-\mathrm{DOE} \\
74-\mathrm{DOE} \\
74-\mathrm{DOE}-2 \\
72-\mathrm{DOJ} \\
64-\mathrm{DOL} \\
71-\mathrm{DOL} \\
72-\mathrm{DOL} \\
\end{array}$ & 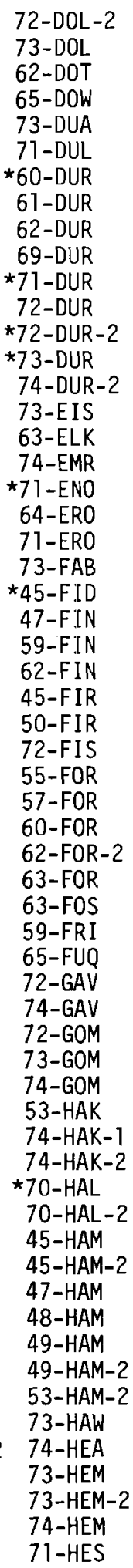 & 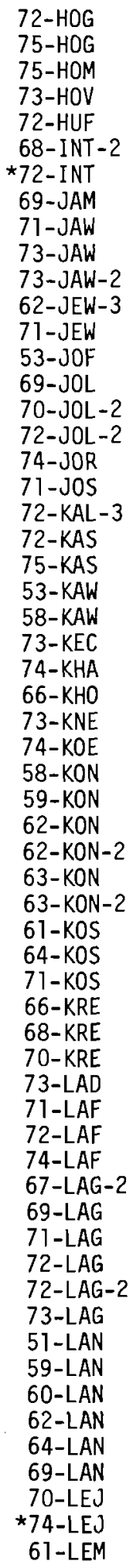 & $\begin{array}{l}\text { 62-LEM } \\
64-L E M \\
66-L E M \\
68-L E M \\
71-L E V-2 \\
72-L E V-2 \\
74-L E V \\
74-L E V-2 \\
75-L E V \\
64-L I A \\
62-L I B \\
62-L I B-2 \\
74-L I K \\
60-L I N \\
62-L I N \\
65-L I N \\
68-L I N \\
68-L I N-2 \\
69-L I N \\
69-L I N-2 \\
\text { *72-LIN } \\
72-L I N-2 \\
47-L I S \\
53-L I S \\
68-L O G \\
70-L O R \\
72-L O R \\
72-L O R-2 \\
74-L O R \\
75-L O R \\
71-L Y A \\
64-L Y U \\
64-L Y U-2 \\
65-L Y U \\
66-L Y U \\
66-L Y U-2 \\
67-L Y U \\
69-L Y U \\
69-L Y U-2 \\
72-L Y U \\
72-L Y U-2 \\
72-L Y U-3 \\
67-M A G \\
69-M A G \\
65-M A H \\
66-M A H \\
67-M A H \\
\text { 70-M9-MAY } \\
69-M A H-2 \\
71-M A H \\
74-M A H \\
71-M A 0 \\
71-M A 0-2 \\
\text { 72-MAO-3 } \\
62-M A R \\
63-M A R \\
\text { 69-MAR } \\
\text { 72-MAY }\end{array}$ & 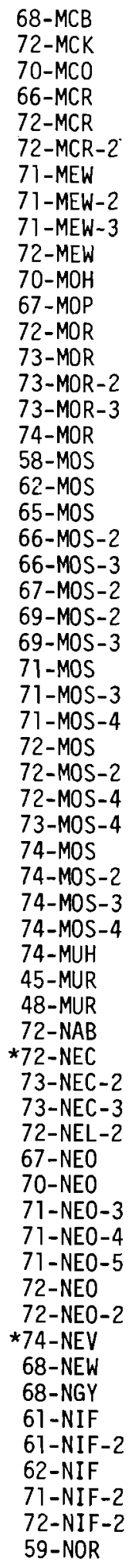 & 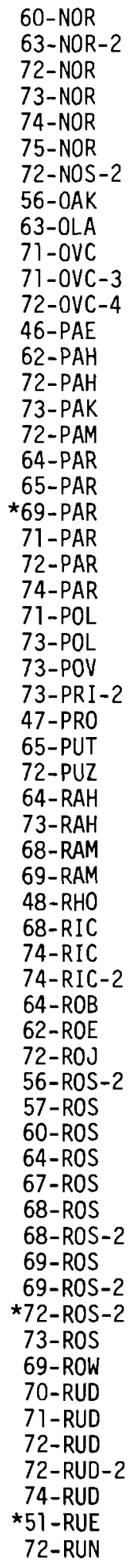 & 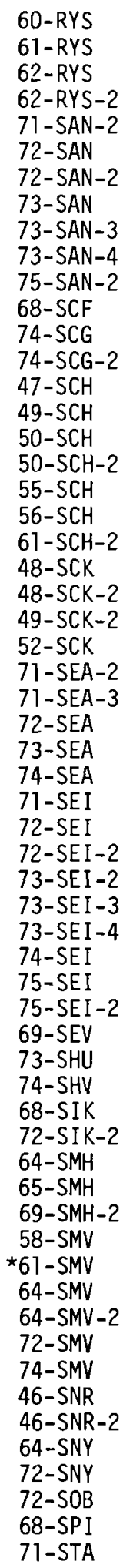 & 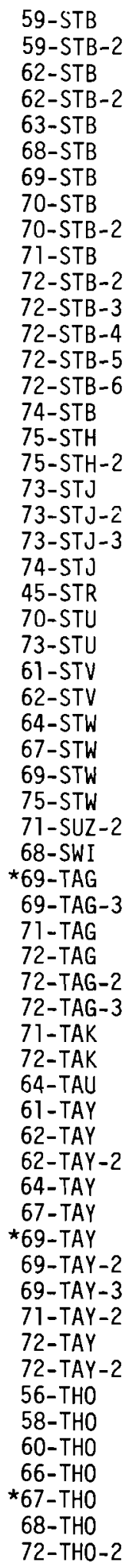 & 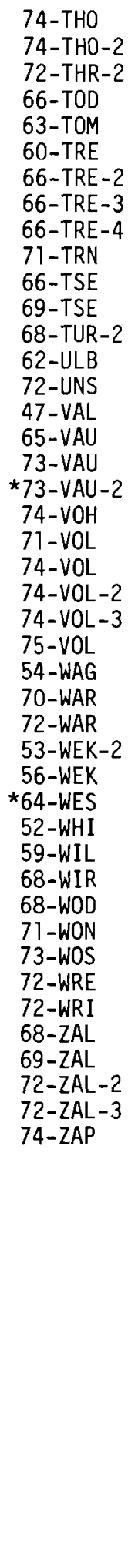 \\
\hline
\end{tabular}


ORGANS, TISSUES, SECRETIONS

\begin{tabular}{|c|c|c|c|c|c|c|c|c|}
\hline 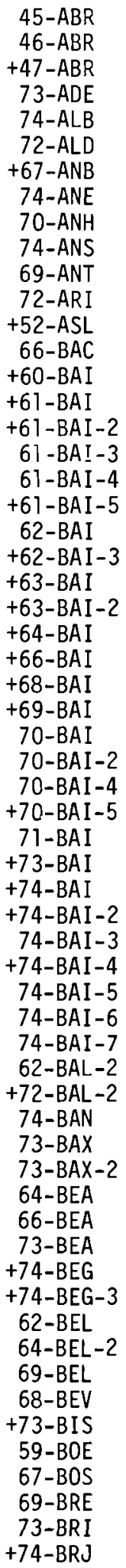 & 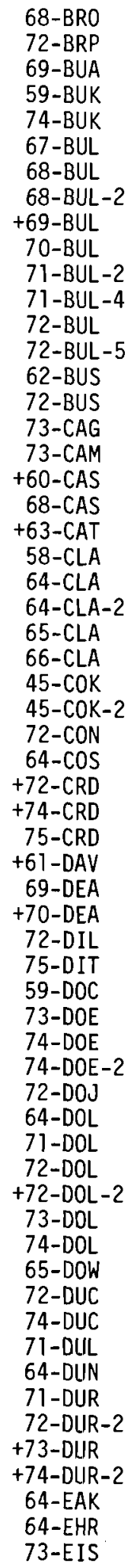 & 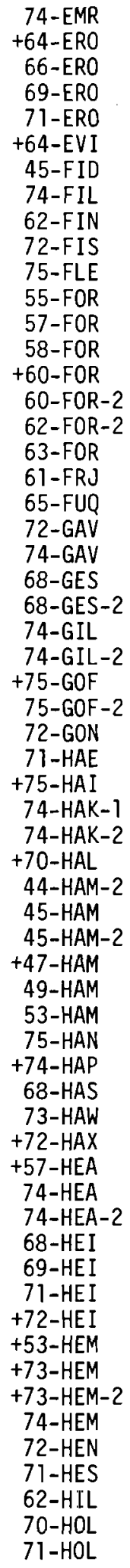 & 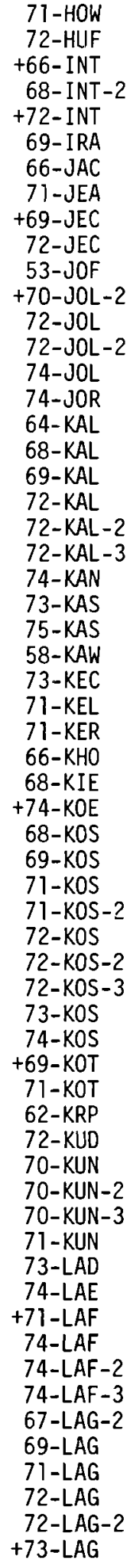 & 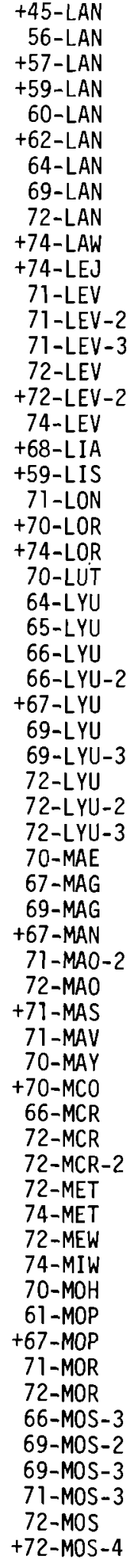 & 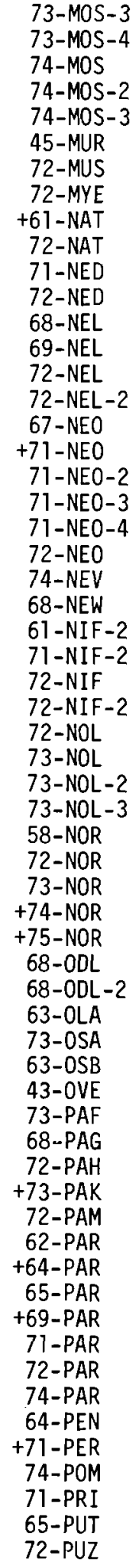 & 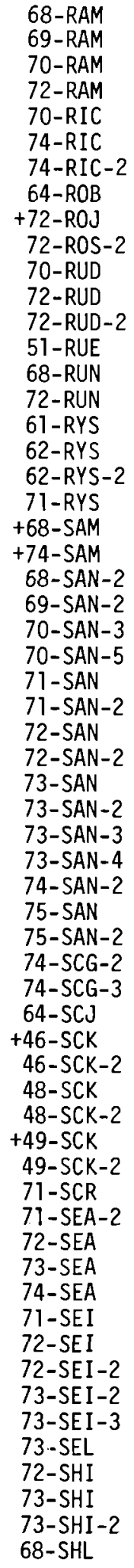 & 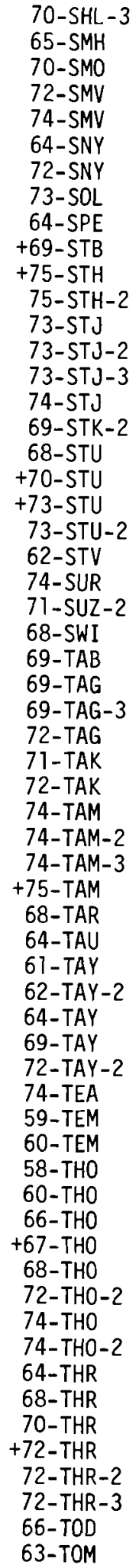 & $\begin{array}{c}\text { 64-TOM } \\
66-\text { TRE } \\
68-T S E \\
69-T S E \\
70-\text { TSE } \\
71-\text { TSE } \\
74-\text { TSE } \\
62-\text { ULB } \\
72-\text { UNS } \\
+71-\text { VAN } \\
+71-\text { VAN-2 } \\
65-\text { VAU } \\
+73-\text { VAU } \\
73-\text { VAU-2 } \\
71-\text { VOL } \\
72-\text { WAI } \\
68-\text { WAL } \\
72-\text { WAR } \\
75-\text { WAS } \\
71-\text { WEH } \\
56-\text { WEK } \\
+64-\text { WES } \\
52-\text { WHI } \\
+67-\text { WIH } \\
59-\text { WIL } \\
60-\text { WIR } \\
67-\text { WIR } \\
+68-\text { WIR } \\
72-\text { WRE } \\
74-\text { WRE } \\
72-\text { WRI } \\
74-\text { YOD } \\
+70-\text { YUI } \\
+68-\text { ZAL } \\
69-\text { ZAL } \\
72-\text { ZAL-3 } \\
+72-\text { ZAY }\end{array}$ \\
\hline
\end{tabular}


ORGANS, TISSUES, SECRETIONS

\begin{tabular}{|c|c|c|c|c|c|c|c|c|}
\hline \multicolumn{5}{|l|}{ Lymph Node } & \multicolumn{2}{|l|}{$\begin{array}{l}\text { Mammary } \\
\text { Gland }\end{array}$} & \multicolumn{2}{|l|}{ Muscle } \\
\hline 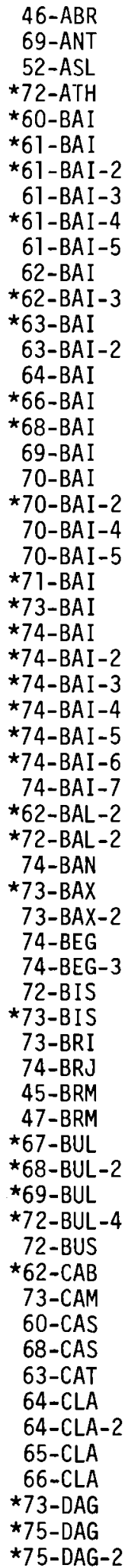 & 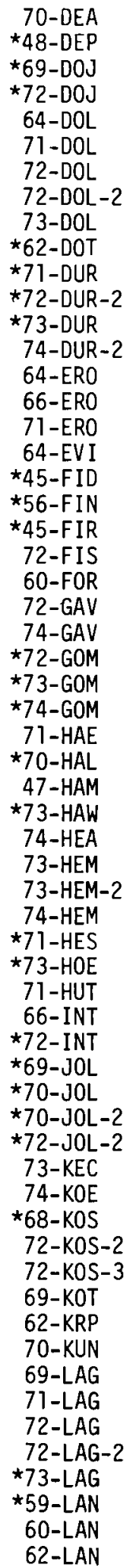 & 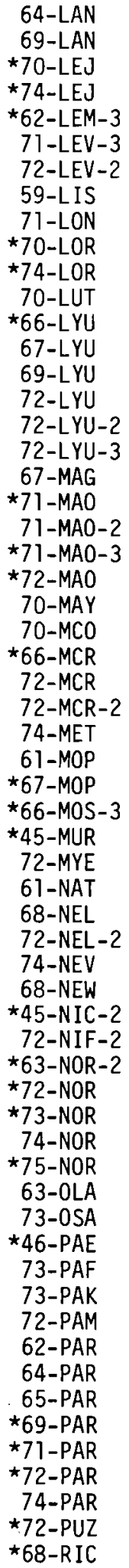 & 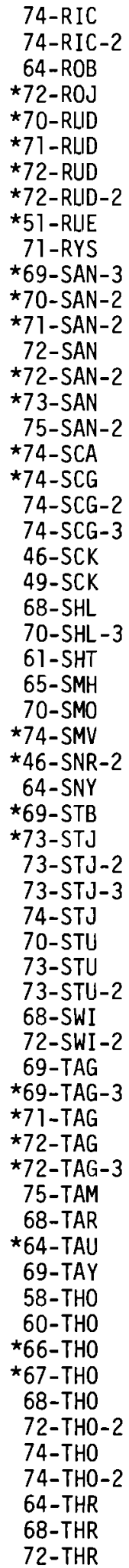 & $\begin{array}{c}\text { 72-THR-2 } \\
\text { 72-THR-3 } \\
\text { *63-TOM } \\
\text { *62-ULB } \\
\text { 72-UNS } \\
\text { 65-VAU } \\
\text { *73-VAU } \\
\text { 73-VAU-2 } \\
\text { 71-VOL } \\
\text { *72-WAR } \\
\text { *72-WAR-2 } \\
\text { 64-WES } \\
\text { *52-WHI } \\
\text { *59-WIL } \\
\text { 67-WIR } \\
\text { 68-WIR }\end{array}$ & 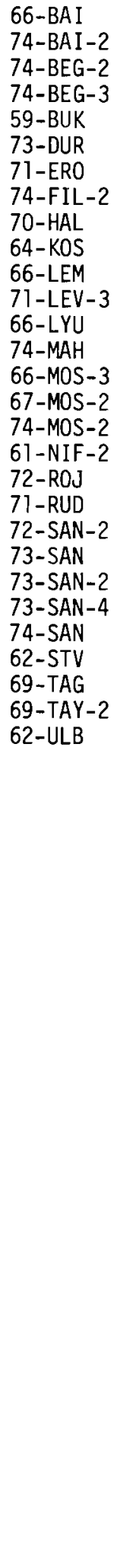 & $\begin{array}{l}\text { 74-BEG-2 } \\
74-B E G-3 \\
65-C O M \\
73-E I S \\
47-F I N \\
47-F I N-2 \\
47-F I N-3 \\
74-H E A \\
72-H O G \\
67-K A U \\
73-K E C \\
69-L A N \\
67-M A G \\
62-M C R \\
72-M I L \\
72-N A T \\
74-N E V \\
68-N G Y \\
63-O L A \\
71-O V C \\
72-O V C \\
64-S A B \\
72-S I K \\
71-S T A \\
67-T H O \\
62-U L B\end{array}$ & 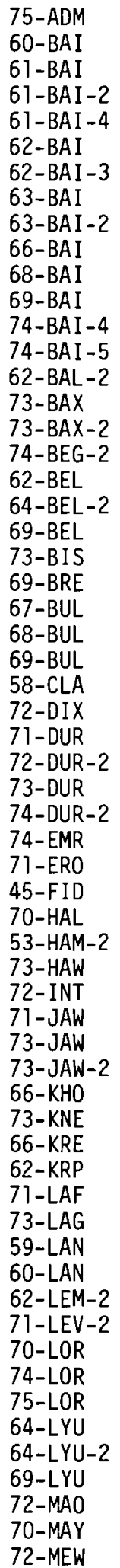 & 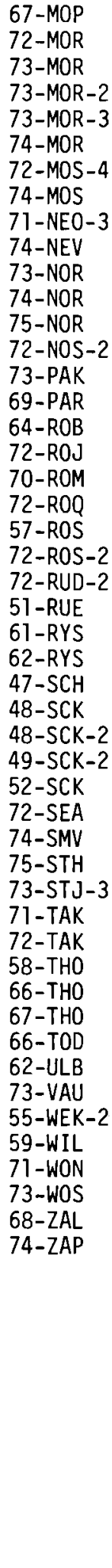 \\
\hline
\end{tabular}

* Indicates Non-Pulmonary Data 
ORGANS, TISSUES, SECRETIONS

\begin{tabular}{|c|c|c|c|c|c|c|c|c|}
\hline tuitary & Skin & & & Spleen & & & & Teeth \\
\hline 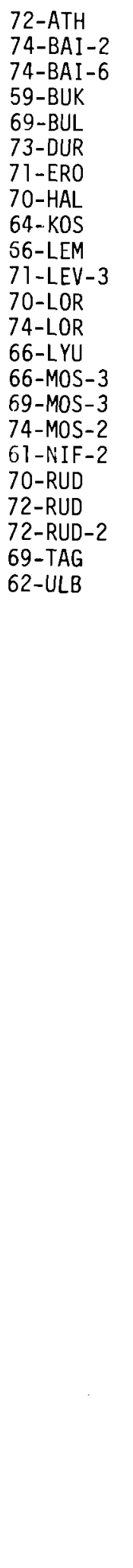 & 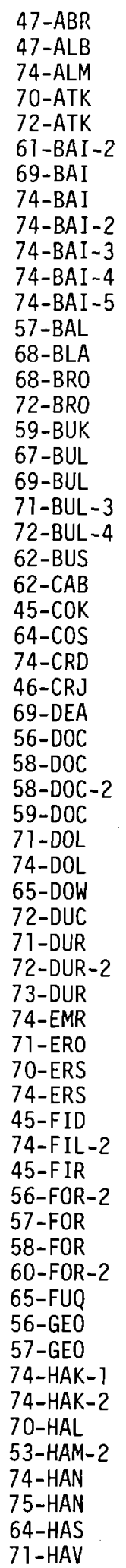 & 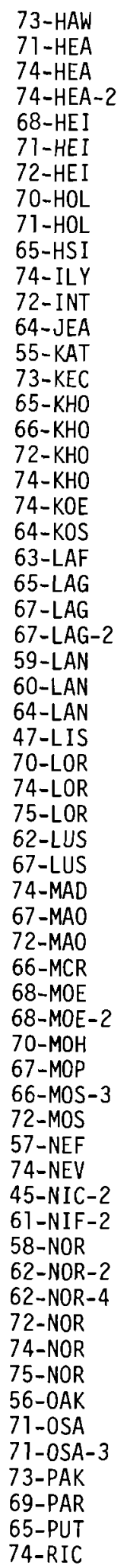 & 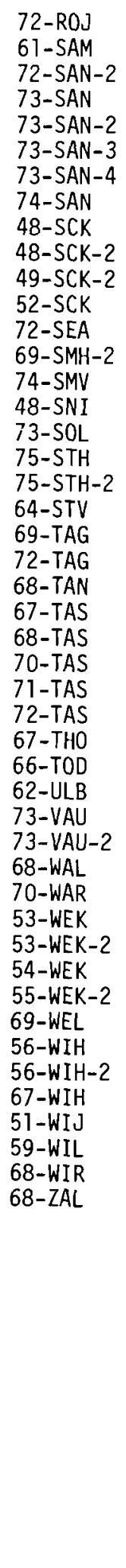 & 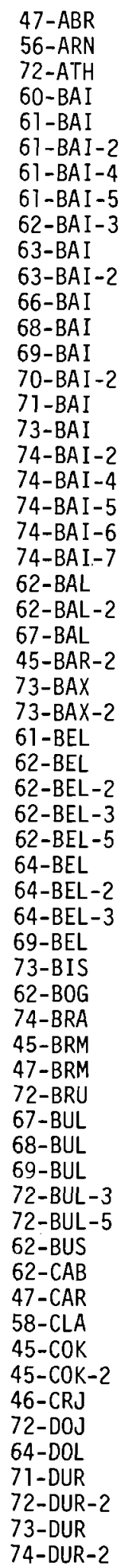 & 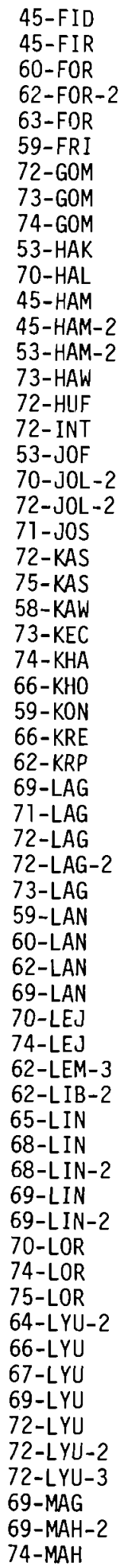 & 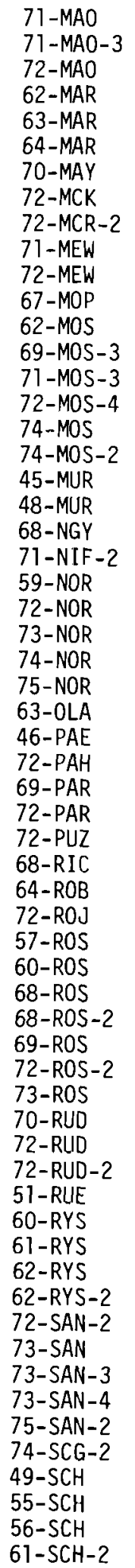 & 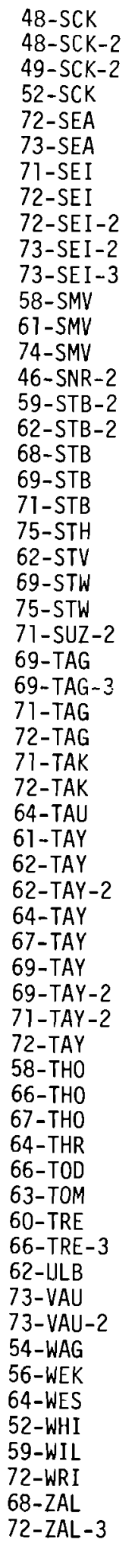 & $\begin{array}{l}\text { 73-BAX } \\
\text { 73-BAX-2 } \\
63-\mathrm{CAT} \\
62-\mathrm{CHR} \\
62-\mathrm{DOT} \\
69-\mathrm{DUR} \\
73-\mathrm{DUR} \\
\text { 45-FID } \\
\text { 70-HAL } \\
\text { 70-HAL-2 } \\
60-\mathrm{JEW} \\
62-\mathrm{JEW}-3 \\
\text { 72-MAO } \\
\text { 74-NOR } \\
69-\mathrm{TAG}-2 \\
71-\mathrm{TAG} \\
\text { 72-TAG-3 } \\
69-\mathrm{TAY}-2 \\
67-\mathrm{THO} \\
62-\mathrm{ULB}\end{array}$ \\
\hline
\end{tabular}


ORGANS, TISSUES, SECRETIONS

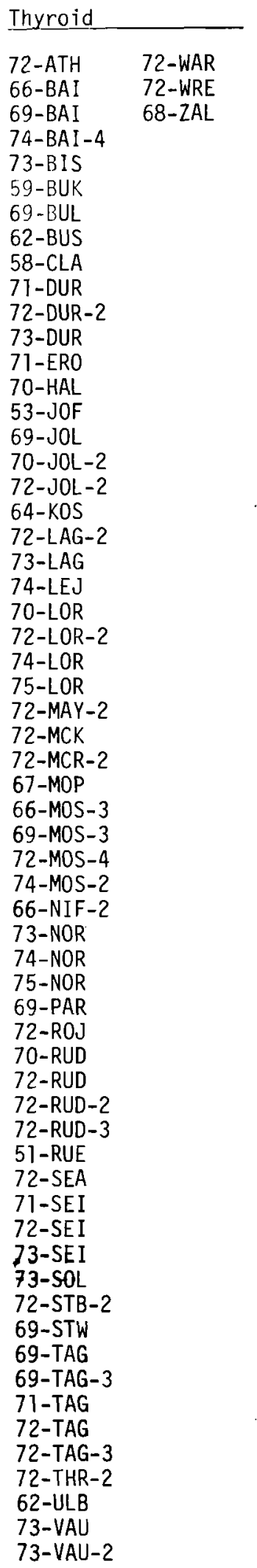


METABOL ISM

$\underline{A} \underline{B} \underline{C} \underline{D} \underline{E}$

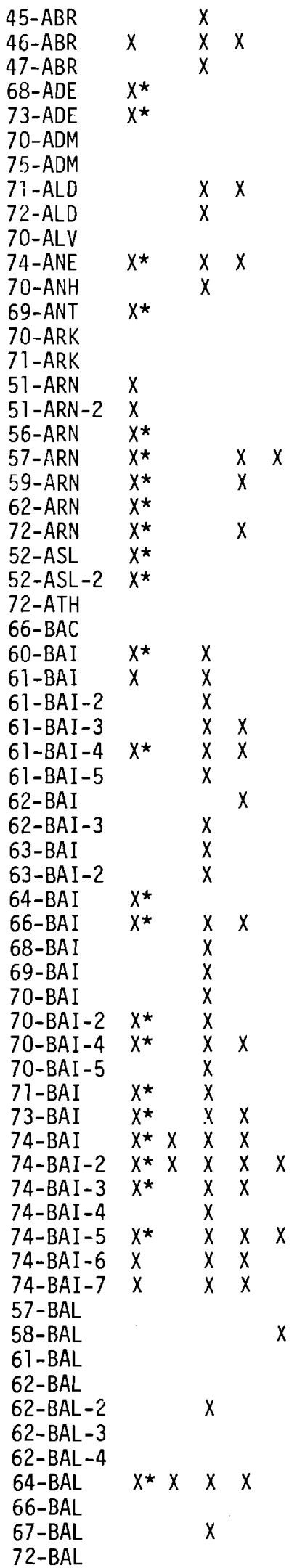

A $\underline{B} \underline{C} \underline{D}$

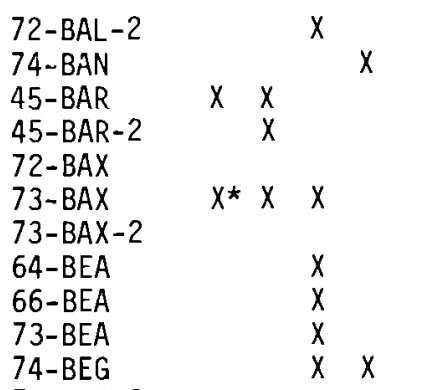

74-BEG-2

74-BEG-3

59-BEL

60-BEL

60-BEL-2

61-BEL

62-BEL

62-BEL-2

62-BEL-3

62-BEL-4

62-BEL-5

64-BEL

64-BEL-2

64-BEL-3

69-BEL

68-BEM

65-BEN

72-BIS

73-BIS

67-BLE

69-BLE

69-BLE-2

71-BLE

65-BOC

66-BOC

70-BOC

59-BOE

67-BOS

71-BRA

74-BRA

69-BRE

75-BR I

74-BRJ

47-BRM

57-BRM

69-BRU

69-BRU-2

71-BRU

72-BRU

59-BUK

68-BUK

69-BUK

67-BUL

67-BUL

68-BUL

68-BUL-2

69-BUL

71-BUL-2

71-BUL-3

71-BUL-4

72-BUL

72-BUL-2

72-BUL-3 $x * x \quad x$

$x$
$x \quad \begin{aligned} & x \\ & x \\ & x \\ & x \\ & x \\ & x\end{aligned}$

$x \quad x$.

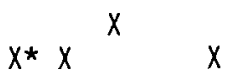

$x$

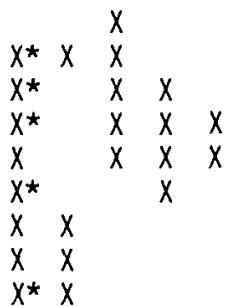

$\begin{array}{lll}x^{*} & x & x \\ x^{*} & x & x\end{array}$

$x^{*} \quad x \quad x$

$\begin{array}{ll}x & \\ x & \\ x & x\end{array}$

$x$

$x *$

$\begin{array}{lll}x & x & x\end{array}$

$x \quad x \quad x$

$x$
$x * x$
$x * x$

$x * x$

$x^{*} \cdot x$

$x \times x$

$x * x x_{x}^{x}$

$\begin{array}{llll}x^{*} & x & x \\ x & x & x\end{array}$

$x^{*} \quad x \quad x$

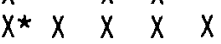

$x$

$x$

$x$

$x \quad x$

$x$
A. Microdistribution

(* - Cellular)

B. Biochemical Binding

C. Retention

D. Dosimetry

E. Data from Non-Adults $\begin{array}{lllll}\text { 72-BUL-4 } & X & X & \\ 62-B U S & & X & & X \\ 62-C A B & X & X & & \\ 73-C A G & X & & X & \end{array}$

63-CAH

69-CAM

73-CAM

47-CAR

60-CAS

68-CAS

61-CAT

62-CAT

63-CAT

74-CHD

$\begin{array}{ll}68-\mathrm{CHI} & x^{\star} X \\ 70-\mathrm{CHI} & x^{*} X\end{array}$

70-CHI-2 $x \quad x$

$72-\mathrm{CHI}$

58-CLA

62-CLA

64-CLA

64-CLA-2

65-CLA

66-CLA

$62-\mathrm{COH}$

45-COK

45-COK-2

$72-\mathrm{CON}$

$73-\mathrm{CON}$

74-CON

47-COP

56-COP

64-COS

74-CRD

46-CRJ

71-CUM

73-DAG

75-DAG

75-DAG-2

74-DAN

61-DAV

48-DEP

$56-D C B$

$56-\mathrm{DOC}$

$58-D O C$

$58-D O C-2$

59-DOC

73-DOE

74-DOE

74-D0E-2

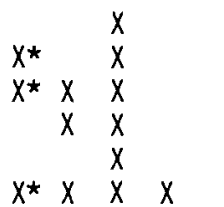

$x * x$

$x \quad x$

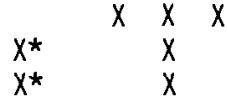

$x * x$

$x * \quad x$

$x * x \quad x$

$x * x \quad x$

$x+x$
$x$
$x$

$x$
$x \quad x \quad x$

$\begin{array}{llll}x & x & & \\ & x & x & \\ & & & \end{array}$

$x * x \quad x$

$x * x \quad x$

$x * x \quad \begin{array}{ll}x & x \\ x & \end{array}$

$x$

$x$

$X^{\star}$
$X^{*}$
$X^{\star}$ 
METABOLISM

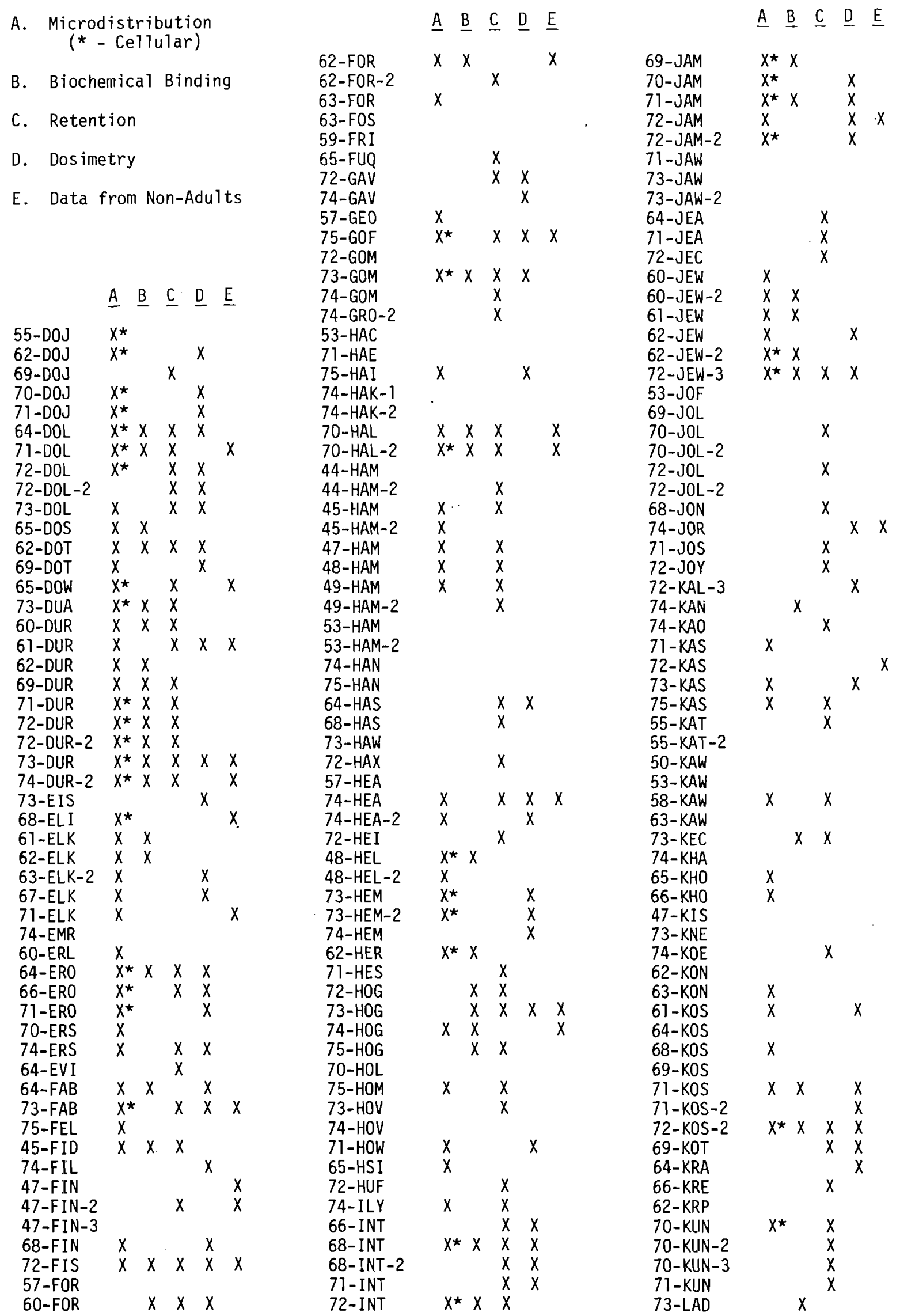


A B $\quad \underline{D} \underline{E}$

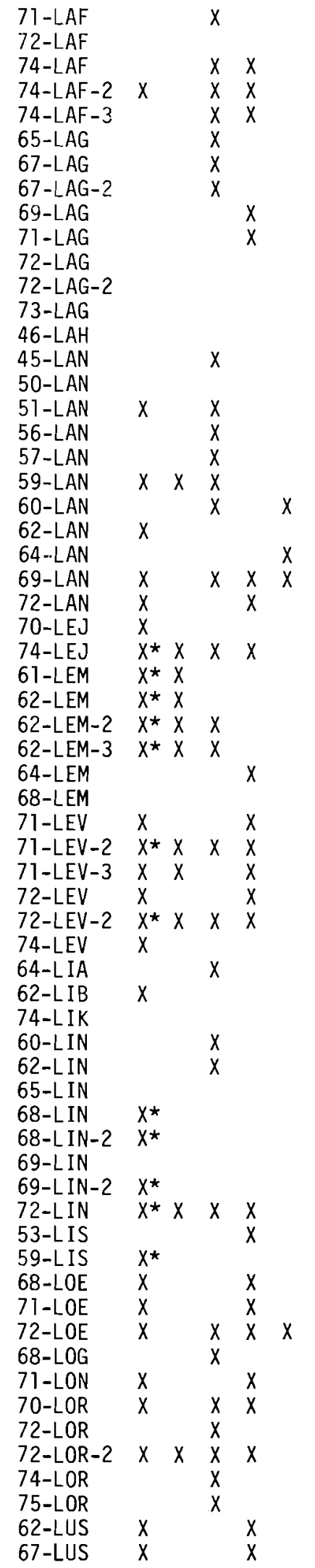

A $\underline{B} \underline{C} \underline{D}$

70-LUT

71-LYA

64-LYU

64-LYU-2

65-LYU

66-LYU

66-LYU-2

67-LYU

68-LYU

69-LYU

69-LYU-2

69-LYU-3

72-LYU

72-LYU-2

72-LYU-3

67-MAG

69-MAG

65-MAH

66-MAH

67-MAH

69-MAH

74-MAH

68-MAI

69-MAJ

73-MAJ

67-MAN

71-MAO

71-MAO-2

72-MAO

68-MAP

62-MAR

63-MAR

64-MAR

69-MAY

70-MAY

72-MAY-2

68-MCB

72-MCK

62-MCR

66-MCR

72-MCR

72-MCR-2

74-MET

71-MEW

71-MEW-2

71-MEW-3

72-MEW

72-MIL

70-MOH

6]-MOP

67-MOP

71-MOR

72-MOR

73-MOR

73-MOR-2

73-MOR-3

73-MOR-4

74-MOR

58-MOS

63-MOS

64-MOS

65-MOS

66-MOS

66-MOS-2

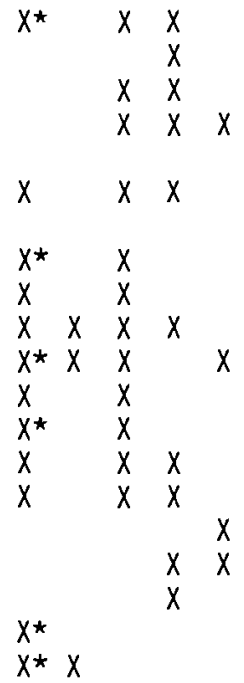$$
x^{\star} x
$$

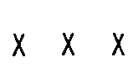

$x * x \quad x \quad x$

$x * x \quad x \quad x \quad x$

$x \quad x$

$x \quad x$

$x$

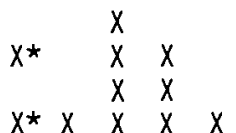

$x * x \times X$

$x * \quad x \quad x$

$x$

$x x$

$\begin{array}{ll}x & x \\ x & \end{array}$

$x \quad \hat{x} x$

$\begin{array}{lll}x & x & x \\ x & x & x\end{array}$

$\begin{array}{lll}x & x \\ x & x\end{array}$

$x^{\star} \quad x \quad x$

$x * \quad \begin{array}{ll}x & x \\ x & x\end{array}$

$X X X$

\section{$\hat{x}$}

$x$
$x$
$x$

$x$
$x$

$x$

$x \quad x$
$x \quad x$
A. Microdistribution

(* - Cellular)

B. Biochemical Binding

C. Retention

D. Dosimetry

E. Data from Non-Adults
A B $\underline{C} \underline{D} \underline{E}$

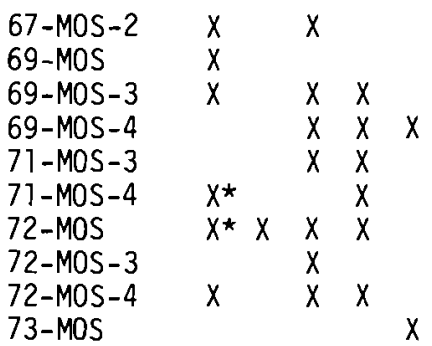

73-MOS-3 $\quad x$

73-MOS-4

74-MOS

74-MOS - 2

74-MOS-4

74-MUH

47-MUN

48-MUR

48-MUR-2

72-MYE

61-NAT

72-NAT

72-NEC

73-NEC

73-NEC -2

73-NEC -3

68-NEL

69-NEL

72-NEL

72-NEL-2

67-NEO

70-NEO

71-NEO-2

71-NEO-3

71-NEO-4

71-NEO-5

72-NEO

72-NEO-2

74-NEV

68-NEW

68-NGY

45-NIC-2

62-NIF

71-NIF

71-NIF-2

72-NIF

72-NIF-2

72-NOL

73-NOL

59-NOR $x$

$x$
$X$

$x$
$X$

$x$

$x$
$x$
$x$

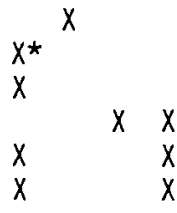

$x$

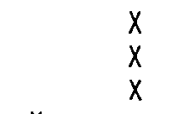

$x$
$x^{\star}$

$x$
$x$
$x$

$x x$

$x * x \quad x$

$x \stackrel{X}{X} X$

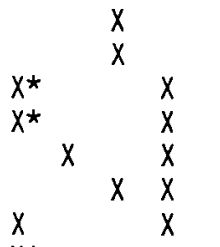

$x \star$

$X^{\star}$ 
METABOL ISM

A. Microdistribution (* - Cellular)

B. Biochemical Binding

C. Retention

D. Dosimetry

E. Data from Non-Adults

60-NOR

63-NOR-2

72-NOR

73-NOR

74-NOR

75-NOR

71-NOS

72-NOS-2

56-OAK

73-OHL

73-OKA

63-OLA

71-OSA

$71-0 S A-2$

71-OSA-3

73-OSA

63-OSB

$71-O V C$

71-OVC-3

72-OVC

72-OVC-2 X

72-OVC-4 $X$

43-OVE

46-PAE

73-PAF

62-PAH

72-PAH

73-PAK

72-PAM

62-PAR

64-PAR

65-PAR

69-PAR

71-PAR

72-PAR

74-PAR

71-PAT

64-PEN

72-PES

72-PES-2

64-PLO

68-POL

71-POL

73-POL

73-POL-2 $\quad X * X$

73-POV

71-PRI

73-PRI-2

65-PUT

72-PUZ

64-RAH

\section{A B C D}


METABOL ISM

$\underline{A} \underline{B} \underline{C} \underline{D} \underline{E}$

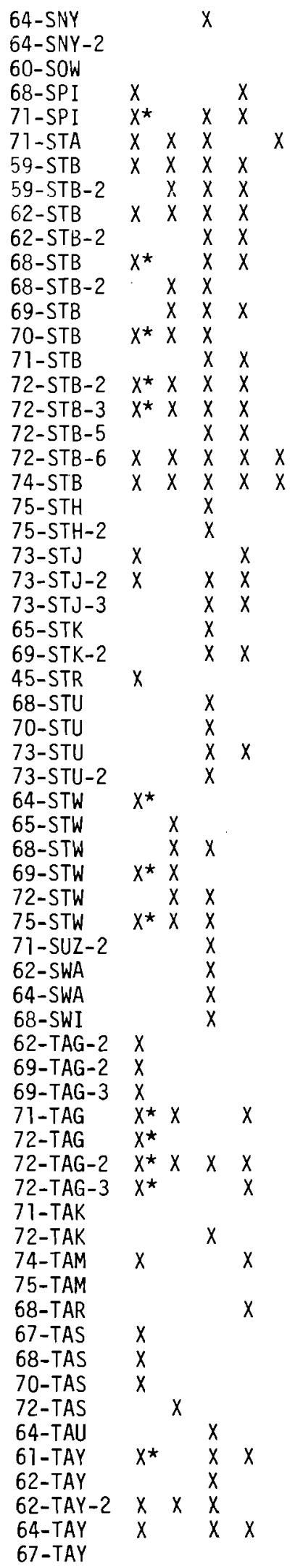

A B $\underline{C} \underline{D}$

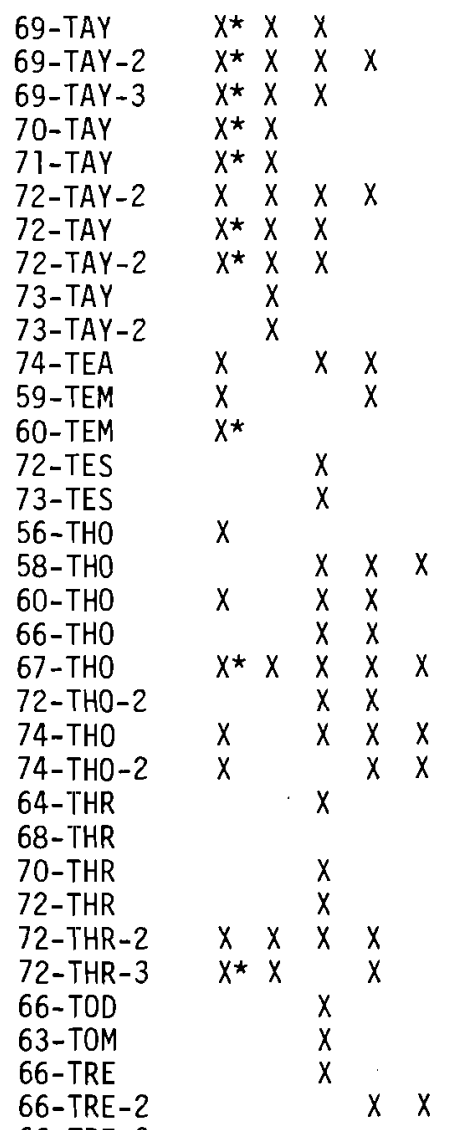

66-TRE-3

$71-T R N$

60-TSE

62-TSE

66-TSE

68-TSE

69-TSE

71-TSE

68-TLIR

68-TLIR-2

61-TWE

62-ULB

72-UNS

60-VAJ

47-VAL

71-VAN

71-VAN-2

56-VAU

62-VAU

65-VAU

67-VAU

71-VAU

72-VAU

73-VAU

73-VAU-2

66-VER

58-VOG

74-VOH

71-VOL

74-VOL

74-VOL-2
A. Microdistribution
(* - Cellular)

B. Biochemical Binding

C. Retention

D. Dosimetry

E. Data from Non-Adults $x * x \quad x$

$x \quad x$

$x \quad x$

$\begin{array}{lll}x & x \\ x & x\end{array}$

$\begin{array}{ll}X & 69-\text { WEL } \\ X & 64-W E S\end{array}$

$x \times$ 72-WHA

$x \quad 52-$ WHI

74-WIE

56-WIH $X$

56-WIH-2

59-WIH

59-WIH-2

60-WIH

67-WIH

59-WIL

67-WIM

53-WIP

60-WIR

67-WIR

68-WIR

68-WOD

71-WON

72-WON

73-WOS

72-WRE

74-WRE

72-WRI

68-ZAL

69-ZAL

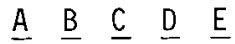

$\underline{A} \underline{B} \underline{C} \underline{D} \underline{E}$

$x$
$x$

$$
x
$$

$x$
$x$

$x$
$x$
$x$

$x$

$x$

$\times \quad \begin{array}{ll}x & x \\ x & \\ x & x \\ x & \\ x & \\ x & \end{array}$

$x$

$x * \quad x$

$$
X X
$$

${ }^{x} x$

X

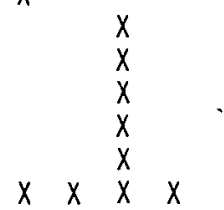

$\hat{x} x$

$x$

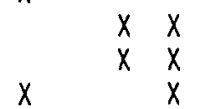

$x$

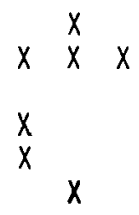




\section{METABOLISM}
A. Microdistribution
(* - Cellular)
B. Biochemical Binding
C. Retention
D. Dosimetry
E. Data from Non-Adults

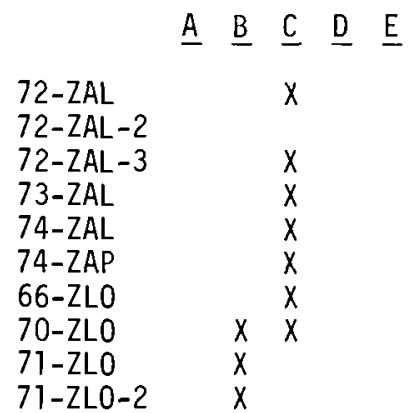




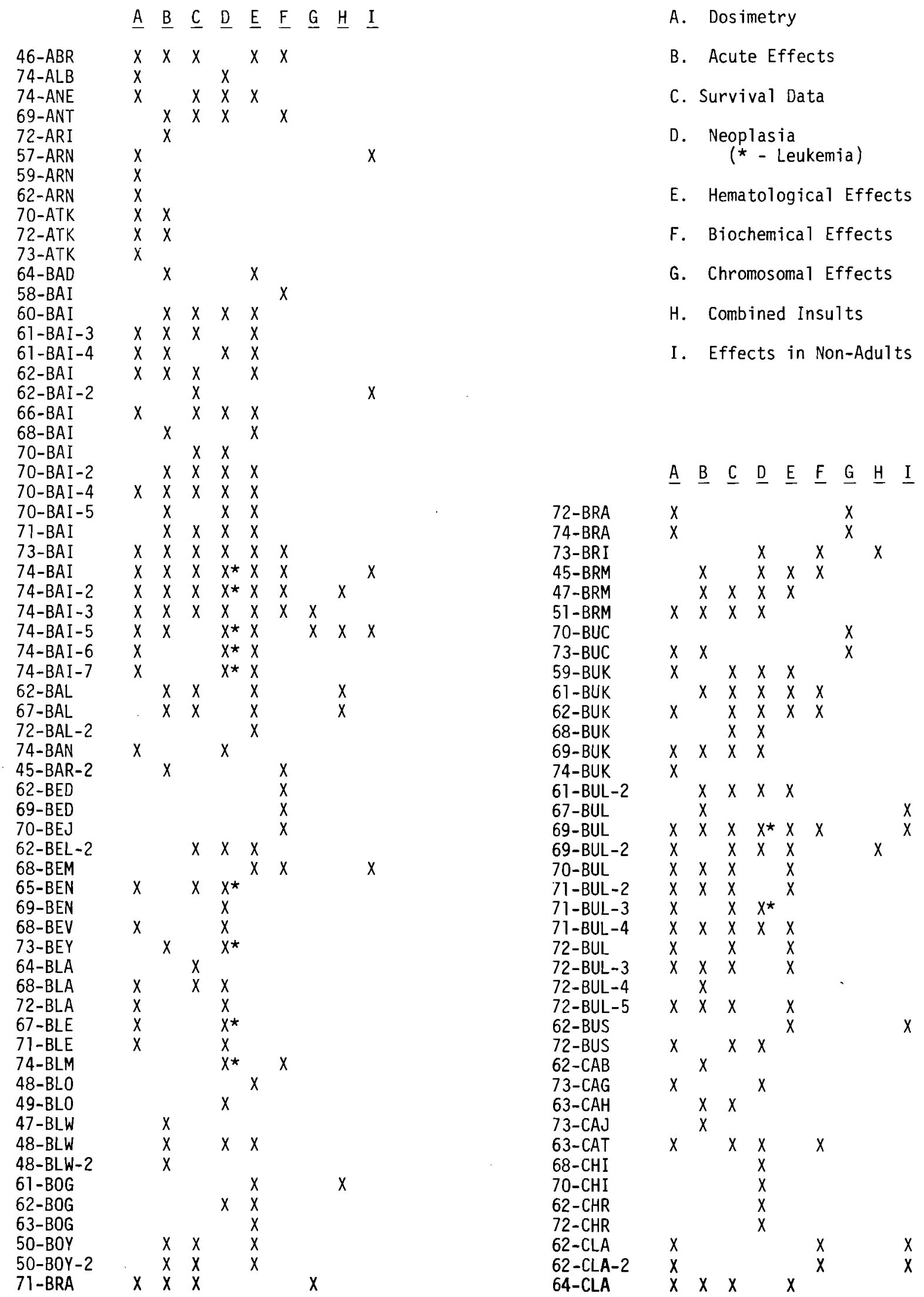


TOXICITY
A. Dosimetry
B. Acute Effects
C. Survival Data
D. Neoplasia

$$
\text { (* - Leukemia) }
$$
E. Hematological Effects
F. Biochemical Effects
G. Chromosomal Effects
H. Combined Insults
I. Effects in Non-Adults

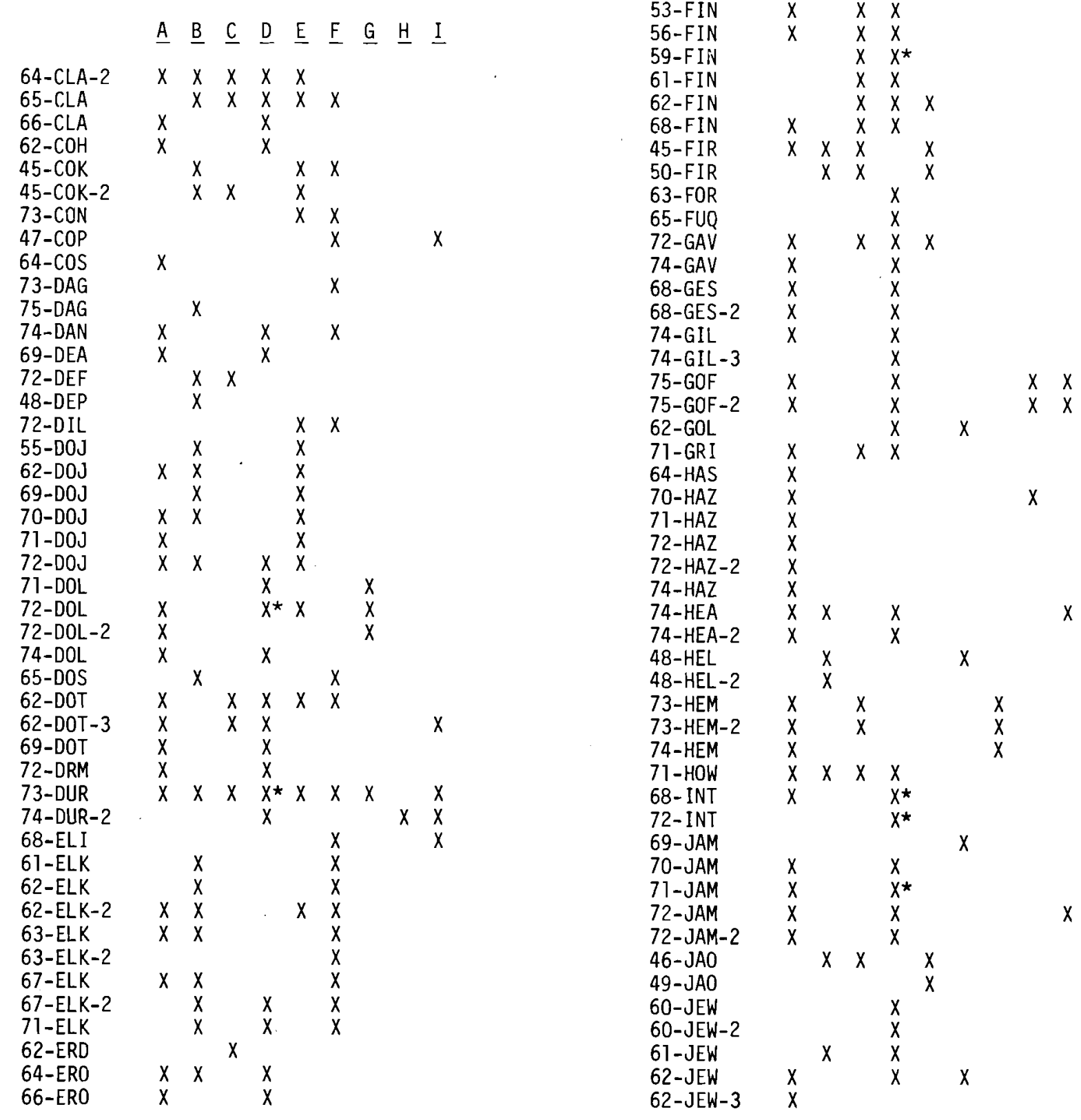


$\underline{A} \quad \underline{B} \quad \underline{C} \quad \underline{D} \quad \underline{E} \quad \underline{F} \quad \underline{G} \quad \underline{H} \quad \underline{I}$

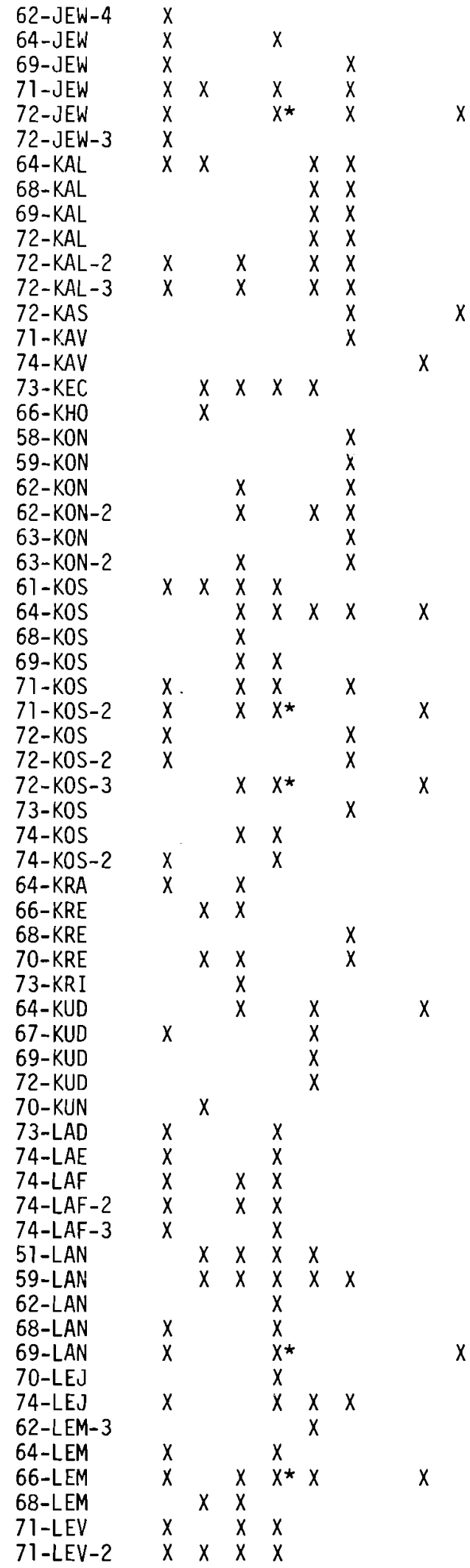

A. Dosimetry

B. Acute Effects

C. Survival Data

D. Neoplasia

(* - Leukemia)

E. Hematological Effects

F. Biochemical Effects

G. Chromosomal Effects

H. Combined Insults

I. Effects in Non-Adults

$\underline{A} \underline{B} \underline{C} \quad \underline{D} \quad \underline{E} \quad \underline{F} \quad \underline{G} \quad \underline{H} I$

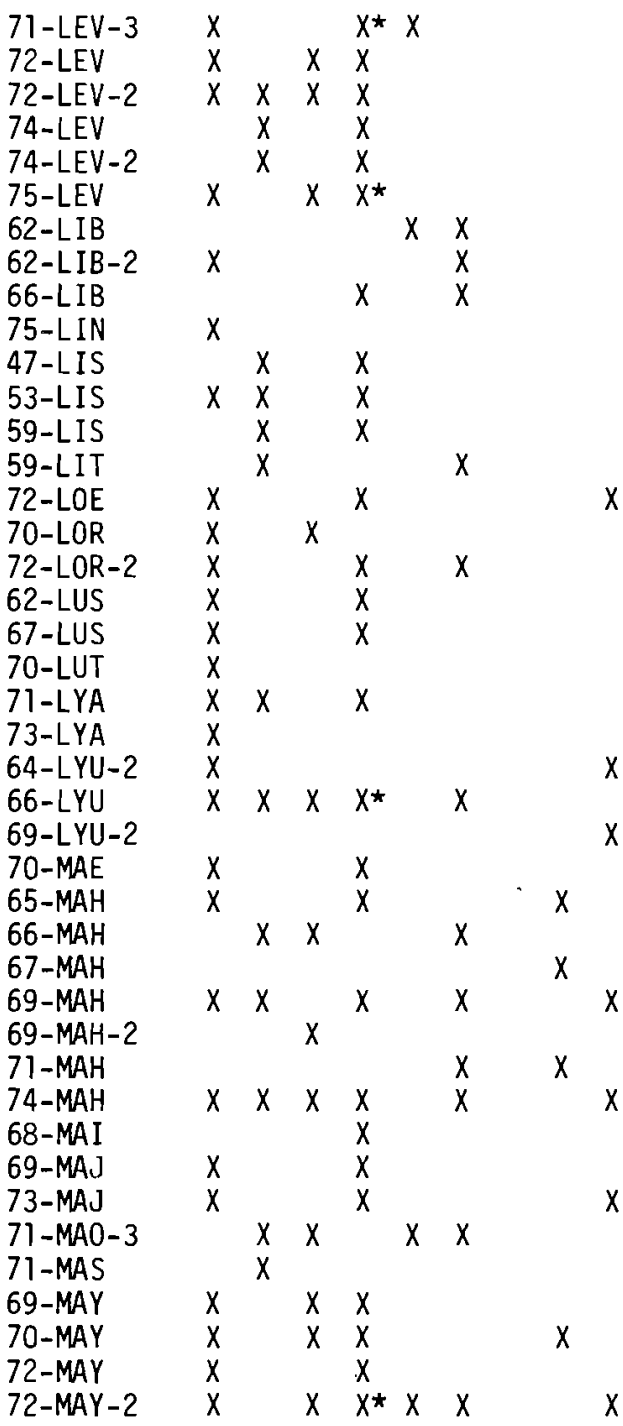


TOXICITY
A. Dosimetry
B. Acute Effects
C. Survival Data
D. Neoplasia
(* - Leukemia)
E. Hematological Effects
F. Biochemical Effects
G. Chromosomal Effects
H. Combined Insults
I. Effects in Non-Adults

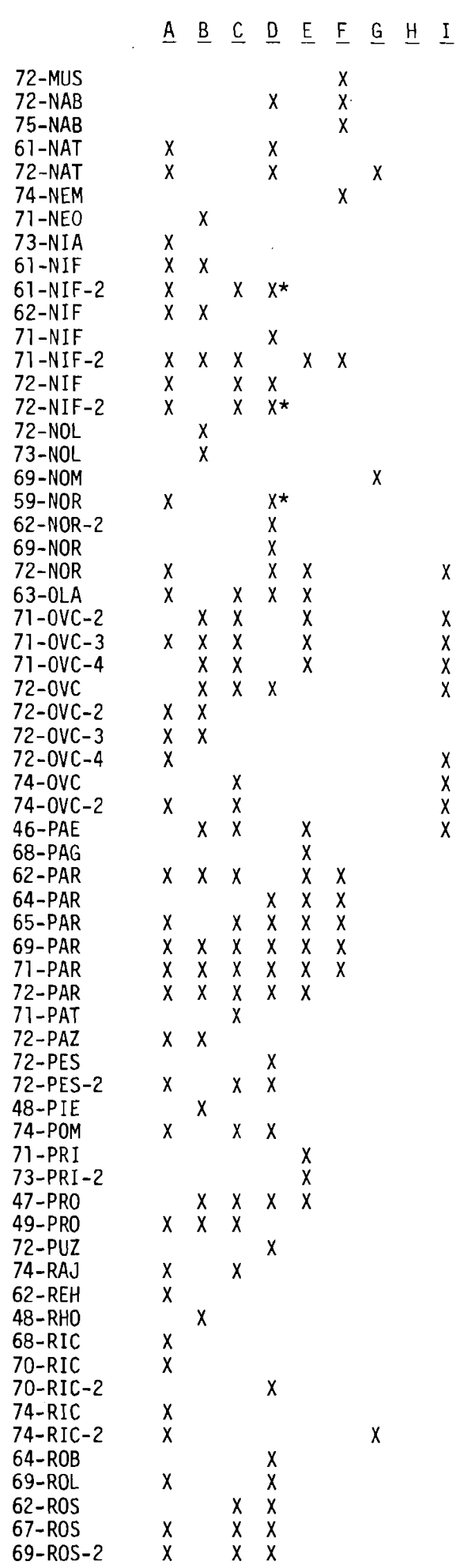

A $\underline{B} \underline{C} \underline{D} \quad \underline{E} \quad \underline{F} \underline{G} \underline{H} \underline{I}$
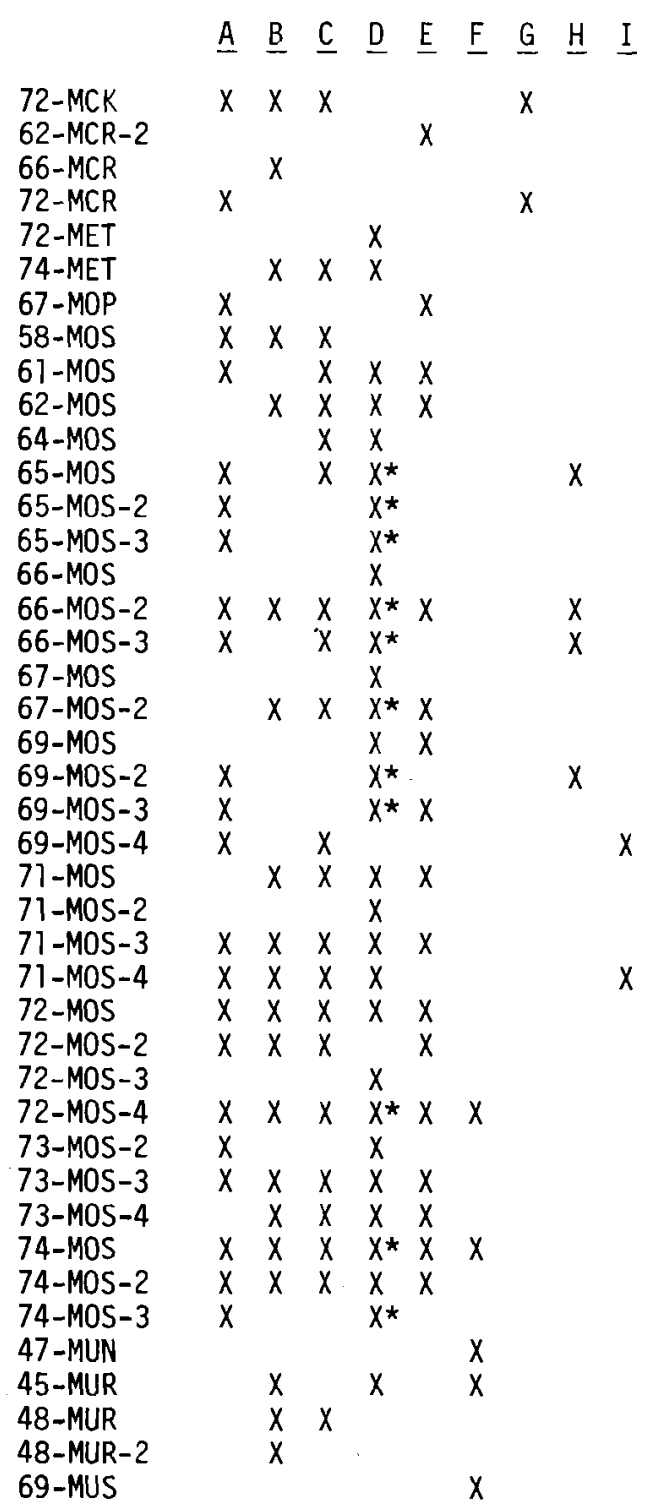
TOXICITY

$\underline{A} \underline{B} \quad \underline{C} \underline{D} \quad \underline{E} \quad \underline{F} \quad \underline{G} \quad \underline{H} \quad \underline{I}$

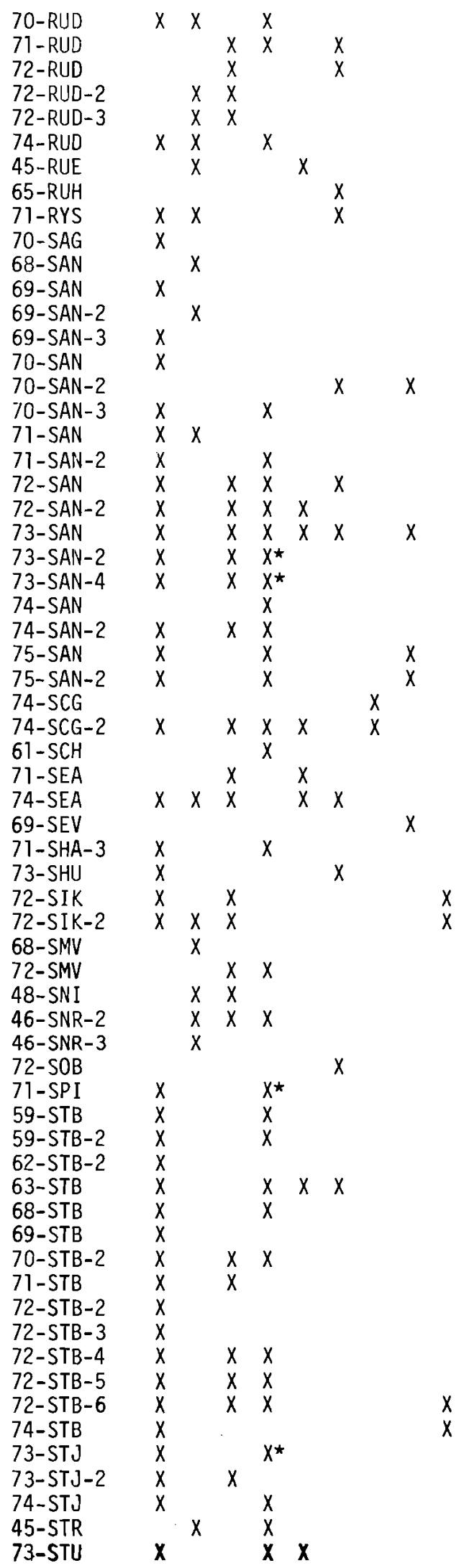
A. Dosimetry
B. Acute Effects
C. Survival Data
D. Neoplasia
(* - Leukemia)
E. Hematological Effects
F. Biochemical Effects
G. Chromosomal Effects
H. Combined Insults
I. Effects in Non-Adults

$\underline{A} \underline{B} \underline{C} \underline{D} \underline{E} \underline{F} \underline{G} \underline{H} \underline{I}$

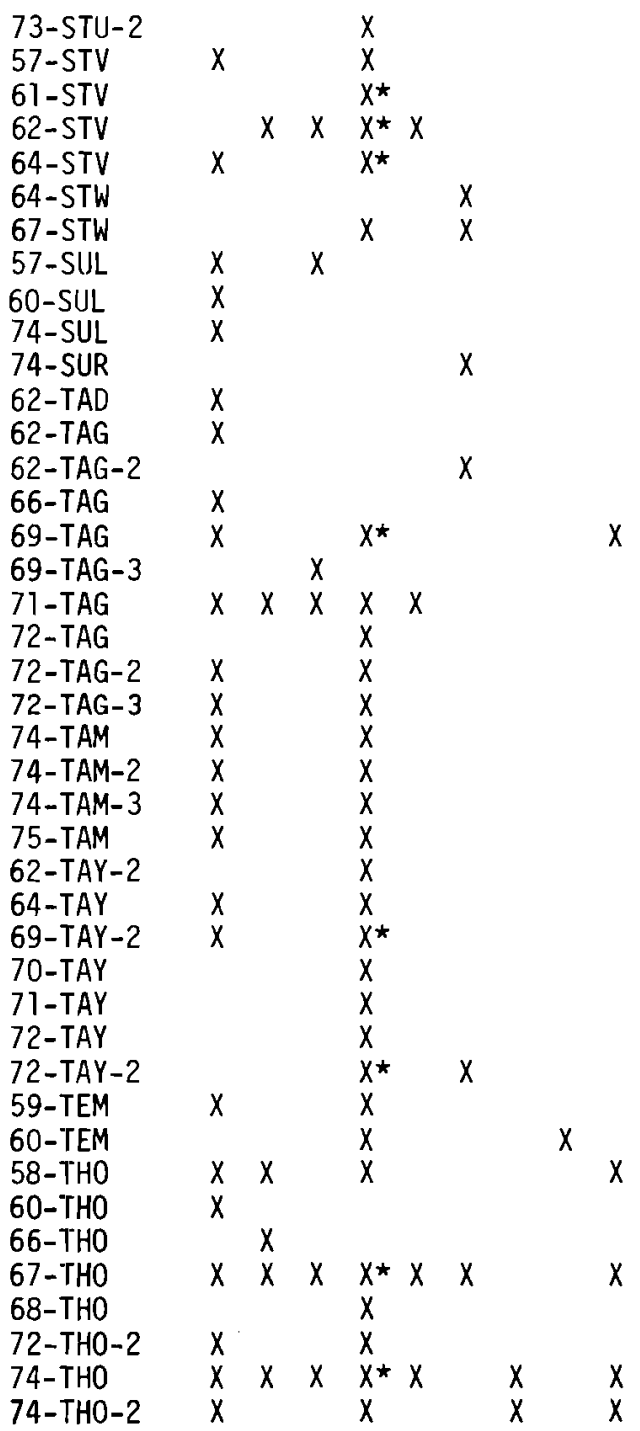


TOXICITY
A. Dosimetry
B. Acute Effects
C. Survival Data
D. Neoplasia
(* - Leukemia)
E. Hematological Effects
F. Biochemical Effects
G. Chromosomal Effects
$H$. Combined Insults
I. Effects in Non-Adults

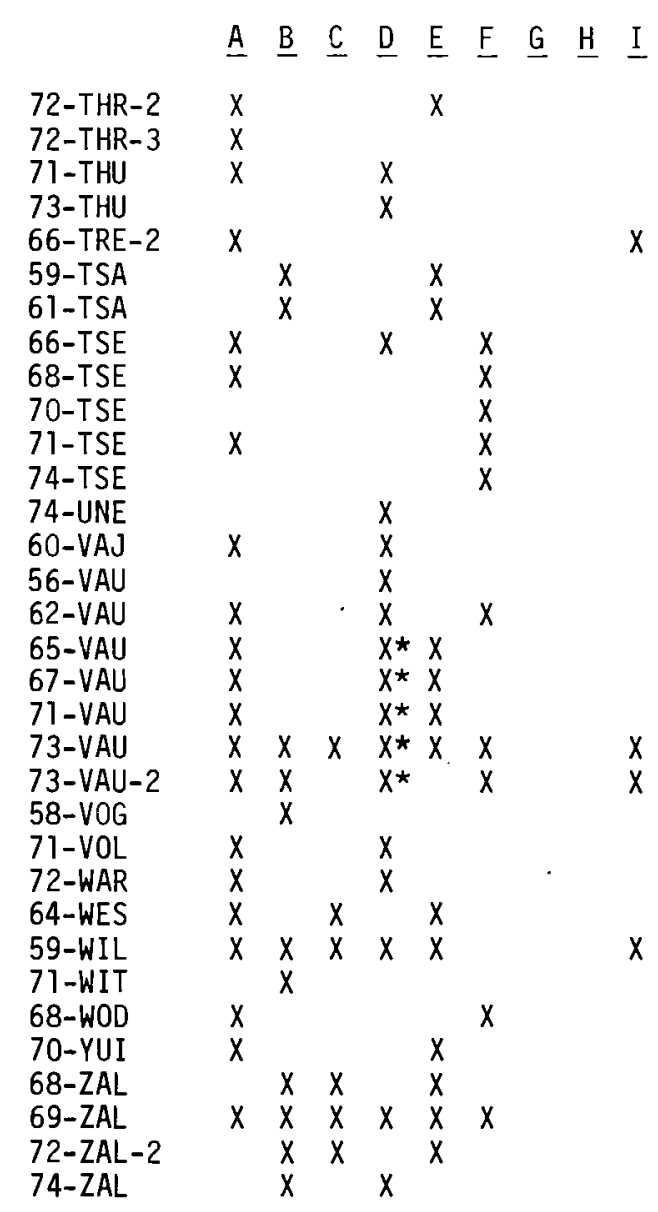




\section{$\underline{A} \underline{B} \underline{C} \underline{D} \underline{E} \quad \underline{F} \underline{G} \underline{H} \underline{I}$}

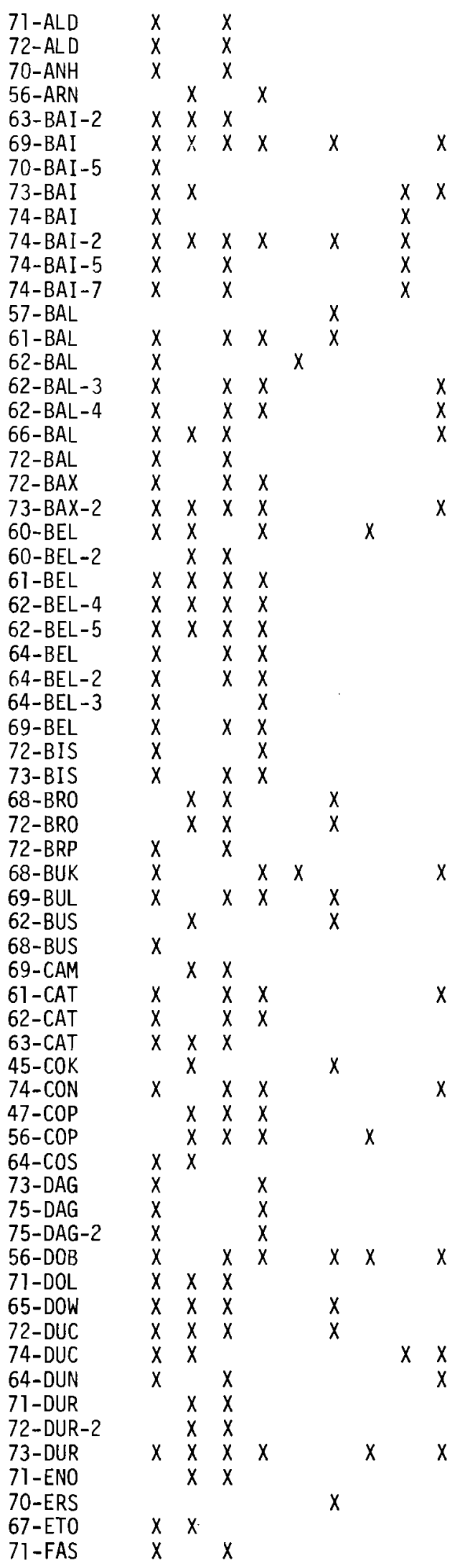

THERAPEUTIC REMOVAL
A. Chelate Therapy
B. Non-Chelate Therapy
C. Excretion Data
D. Distribution Data
E. Survival or Tumor Data
F. External Decontamination
G. Colloid Therapy
H. Lavage Therapy
I. Chelate Toxicity

$\underline{A} \quad \underline{B} \quad \underline{D} \quad \underline{D} \quad \underline{E} \quad \underline{F} \quad \underline{G} \underline{H} \quad \underline{I}$

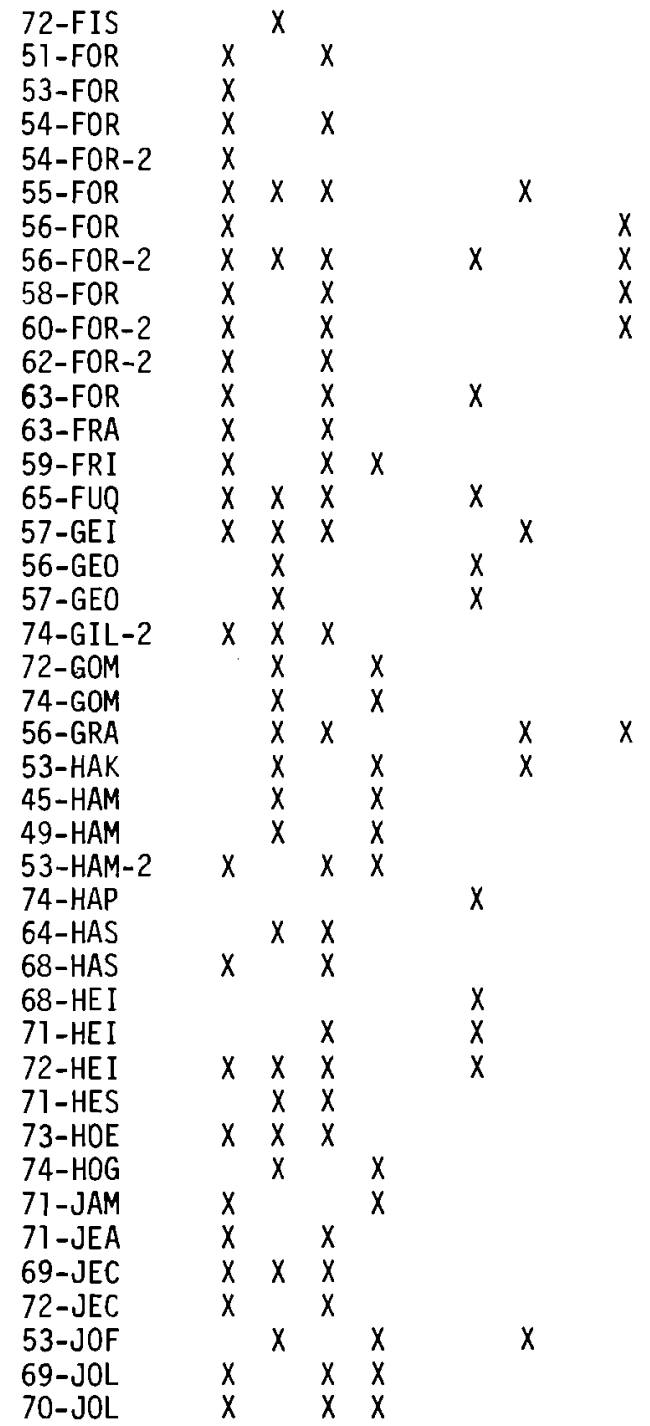


THERAPEUTIC REMOVAL
A. Chelate Therapy
B. Non-Chelate Therapy
C. Excretion Data
D. Distribution Data
E. Survival or Tumor Data
F. External Decontamination
G. Colloid Therapy
H. Lavage Therapy
I. Chelate Toxicity

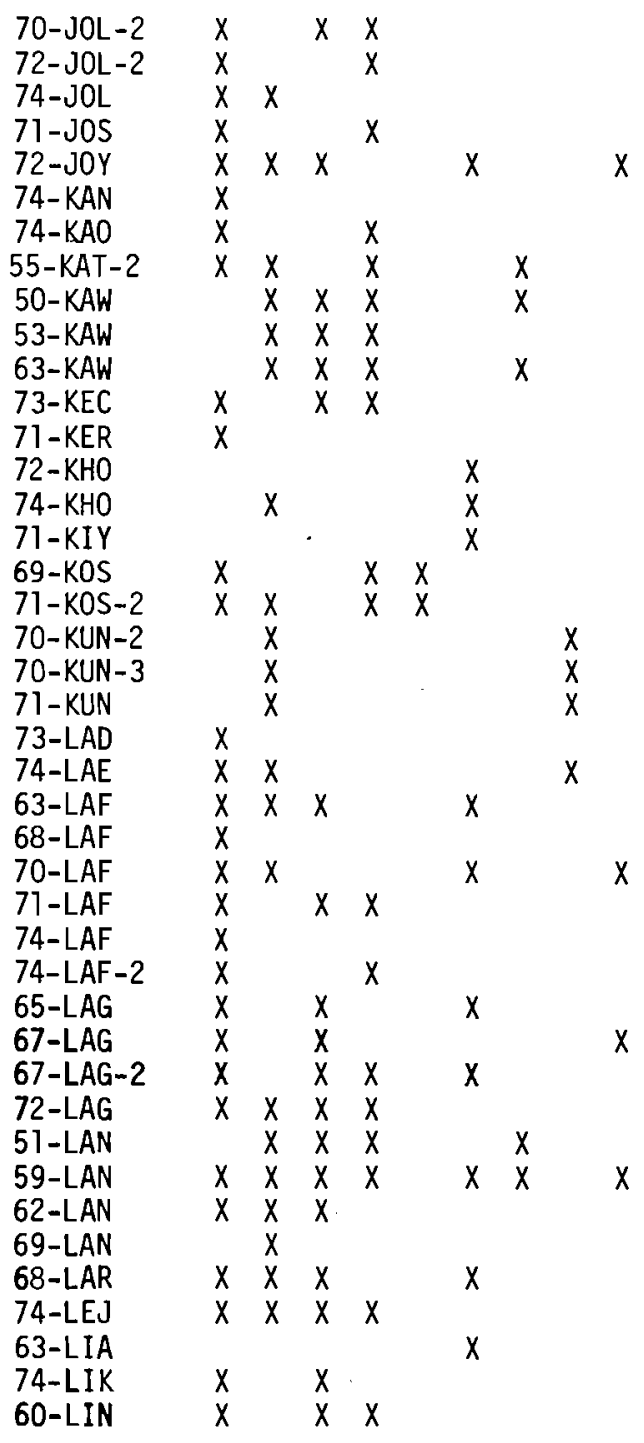

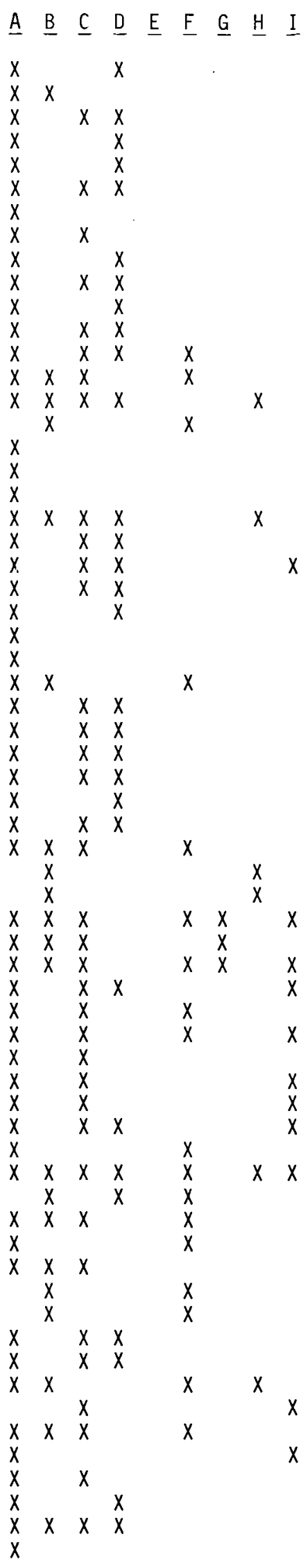

62-LIN
$72-L I N$
$68-L O G$
$65-L Y U$
$66-$ LYU-2
$68-$ LYU
$68-M A I$
$67-M A N$
$72-M A 0$
$62-M A R$
$63-M A R$
$64-M A R$
$68-M C B$
$66-M C R$
$72-M C R$
$68-M O E$
$68-M O E-2$
$69-M O E$

71-MOR

72-MOR

73-MOR

73-MOR-3

74-MOR

58-MOS

64-MOS

69-MOS

57-NEF

70-NEO

$71-\mathrm{NEO}-2$

$71-\mathrm{NEO}-3$

71-NEO-4

72-NEO

$72-N E O-2$

$45-N I C-2$

73-NOL-2

73-NOL-3

56-NOR

$56-N O R-2$

$58-N O R$

60-NOR

62-NOR

62-NOR-2

62-NOR-3

$62-N O R-4$

63-NOR

63-NOR-2

69-NOR

72-NOR

56-OAK

71-OHL

71-OHL-2

73-OHL

71-OSA

71-OSA-3

62-PAH

72-PAH

73-PAK

71-PER

64-PIJ

75-PLA

64-PLO

71-POL

73-POL

73-POL-2 
THERAPEUTIC REMOVAL

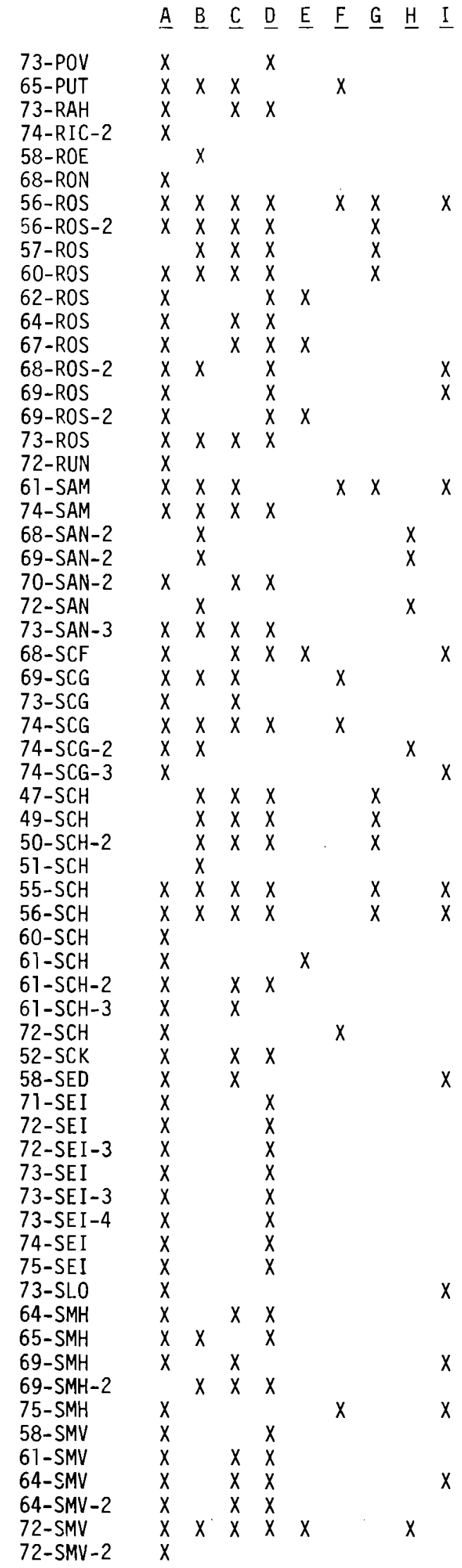
A. Chelate Therapy
B. Non-Chelate Therapy
C. Excretion Data
D. Distribution Data
E. Survival or Tumor Data
F. External Decontamination
G. Colloid Therapy
H. Lavage Therapy
I. Chelate Toxicity

A $\underline{B} \underline{C} \underline{D} \underline{E} \underline{F} \underline{G} \underline{H}$

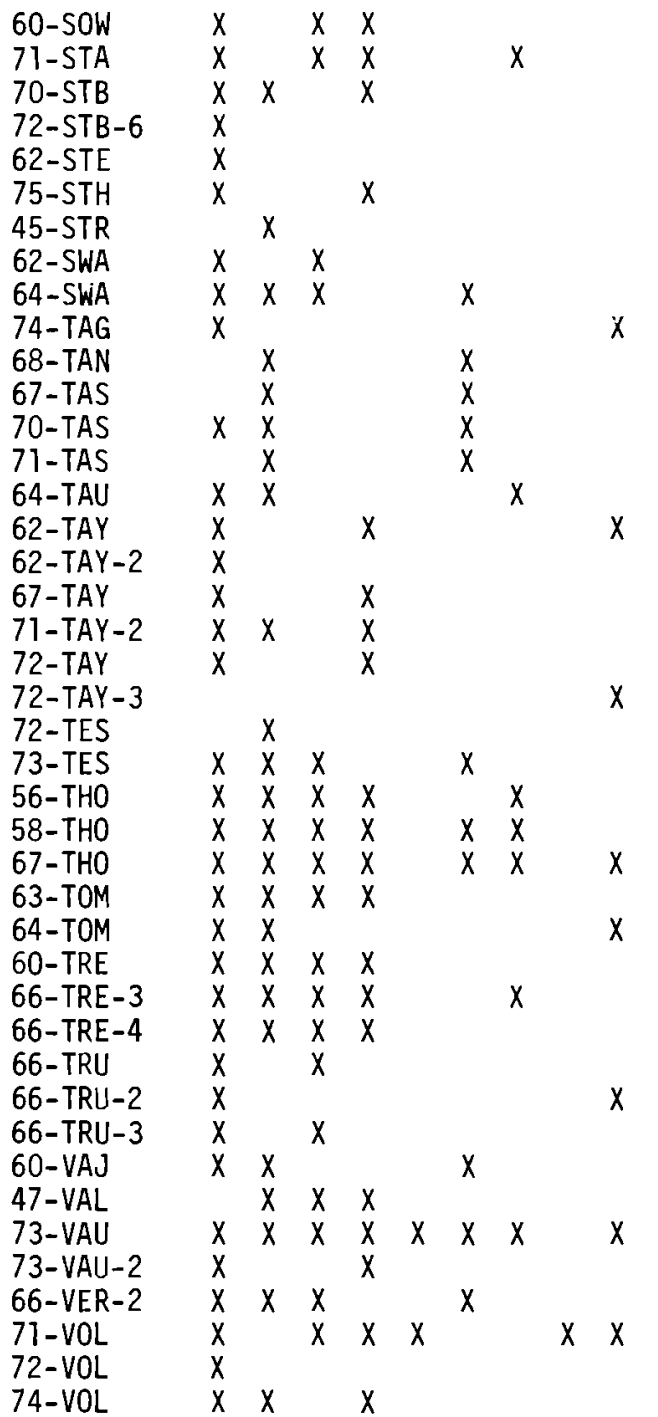


THERAPEUTIC REMOVAL
A. Chelate Therapy
B. Non-Chelate Therapy
c. Excretion Data
D. Distribution Data
E. Survival or Tumor Data
F. External Decontamination
G. Colloid Therapy
H. Lavage Therapy
I. Chelate Toxicity

$\underline{A} \underline{B} \underline{C} \underline{D} \underline{E} \underline{F} \underline{G} \underline{H} \underline{I}$

\begin{tabular}{|c|c|c|c|c|c|c|}
\hline 74-VOL-2 & $x$ & & & $x$ & & \\
\hline $74-V O L-3$ & $x$ & & & $X$ & & \\
\hline $75-$ VOL & $X$ & $x$ & & $X$ & & \\
\hline 54-WAG & $x$ & $x$ & $x$ & $x$ & & $X$ \\
\hline 68-WAL & $x$ & $X$ & $x$ & & $X$ & \\
\hline 70-WAR & $x$ & & $x$ & & $x$ & \\
\hline 72-WAR & $x$ & & & $x$ & & \\
\hline 72-WAR-2 & $x$ & $X$ & $x$ & $x$ & & \\
\hline 71-WEH & & $\begin{array}{l}X \\
y\end{array}$ & & $x$ & & \\
\hline 53-WEK & & $X$ & & & $x$ & \\
\hline 53-WEK-2 & & $X$ & & & $x$ & \\
\hline 55-WEK & $x$ & $x$ & & $X$ & & $X$ \\
\hline 52-WHI & & $X$ & $x$ & $X$ & & $X$ \\
\hline 56-WIH & & $x$ & & & $X$ & \\
\hline 56-WIH-2 & & $X$ & $x$ & & & \\
\hline 59-WIH & $X$ & $x$ & $X$ & & & \\
\hline 59-WIH-2 & $X$ & $X$ & $X$ & & & \\
\hline 60-WIH & $x$ & $x$ & $x$ & & $x$ & \\
\hline 67-WIH & $x$ & $\begin{array}{l}X \\
x\end{array}$ & $x$ & & $\begin{array}{l}x \\
x\end{array}$ & $x$ \\
\hline $51-410$ & & $x$ & & & $x$ & $\Lambda$ \\
\hline 72-WRE & $\begin{array}{l}x \\
y\end{array}$ & & $\hat{y}$ & $X$ & & \\
\hline $\begin{array}{l}\text { /2-LAL } \\
73-2 A L\end{array}$ & $\begin{array}{l}x \\
x\end{array}$ & & $\hat{x}$ & & & \\
\hline & & & & & & \\
\hline
\end{tabular}


HUMAN EXPERIENCE

$$
\underline{A} \underline{B} \underline{C} \underline{D} \underline{E} \underline{F} \underline{G} \underline{H} \underline{I}
$$

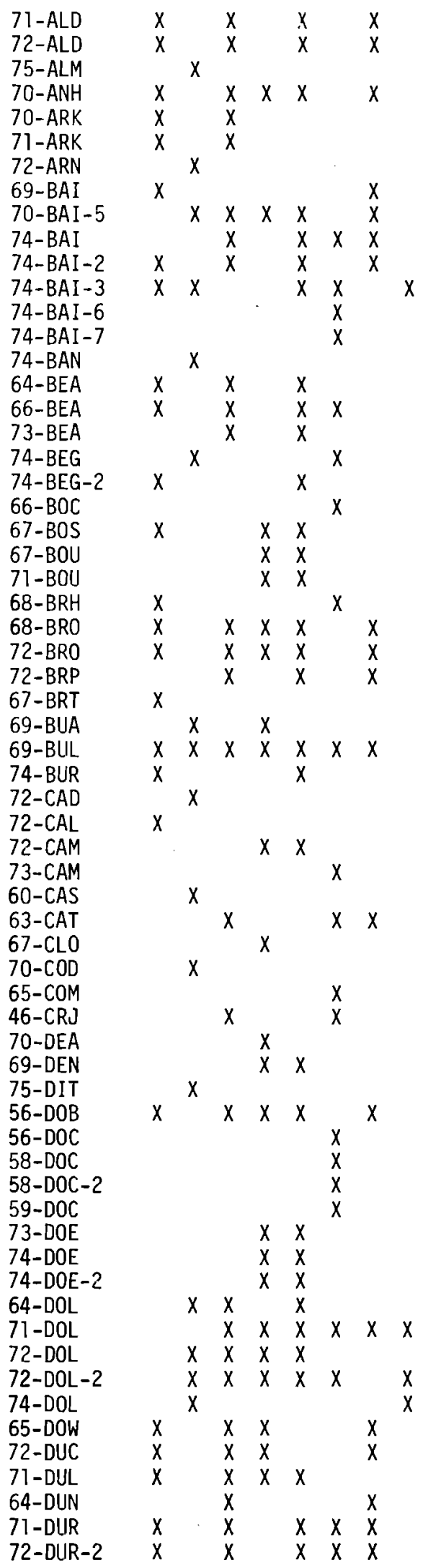
A. Exposures
B. Dosimetry
C. Excretion Data
D. External Counting
E. Body Burden Estimates
F. Autopsy Data
G. Therapy
H. Biological Effects
I. Psychosocial Effects

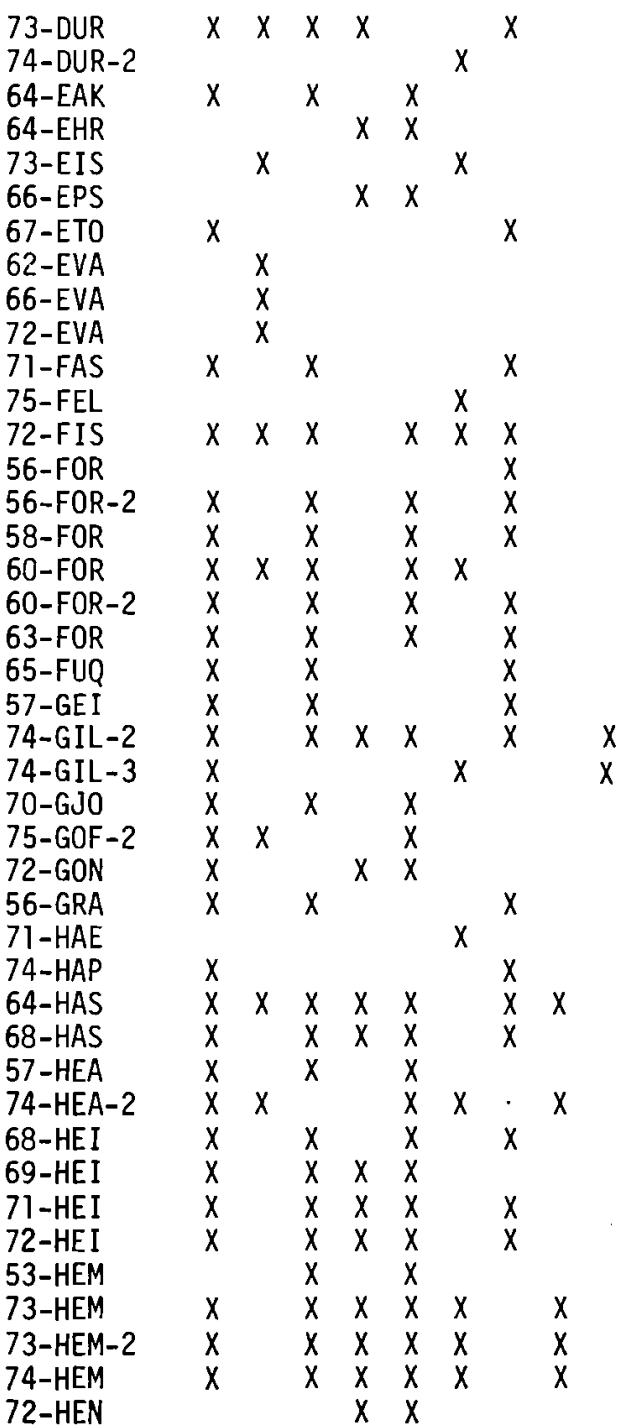

$\begin{array}{lllllllll}A & B & C & D & E & F & G & H & I\end{array}$

75-GOF-2

$72-\mathrm{GON}$

74-HAP

64-HAS

68-HAS

57-HEA

74-HEA-2

68-HE

69-HE

71-HEI

$72-\mathrm{HE}$

53-HEM

73-HEM-2

74-HEM

72-HEN 
HUMAN EXPERIENCE
A. Exposures
B. Dos imetry
C. Excretion Data
D. External Counting
E. Body Burden Estimates
F. Autopsy Data
G. Therapy
H. Biological Effects
I. Psychosocial Effects

$\underline{A} \underline{B} \underline{C} \underline{D} \underline{E} \underline{F} \underline{G} \underline{H} \underline{I}$

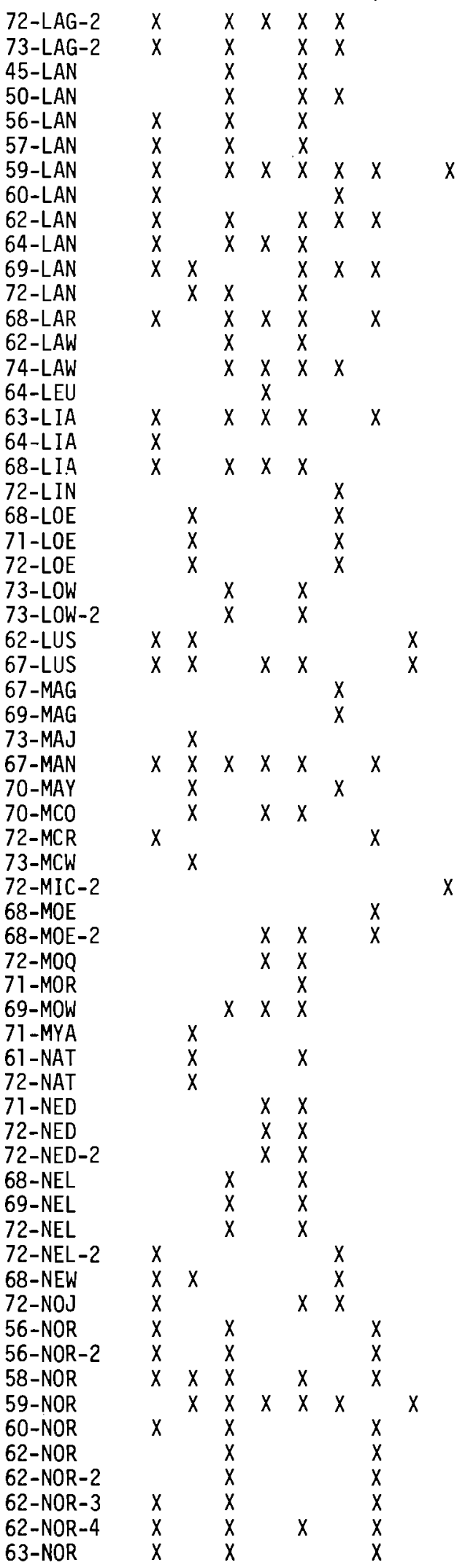


$\underline{A} \quad \underline{B} \quad \underline{C} \quad \underline{D} \quad \underline{E} \quad \underline{F} \quad \underline{G} \quad \underline{H} \quad \underline{I}$

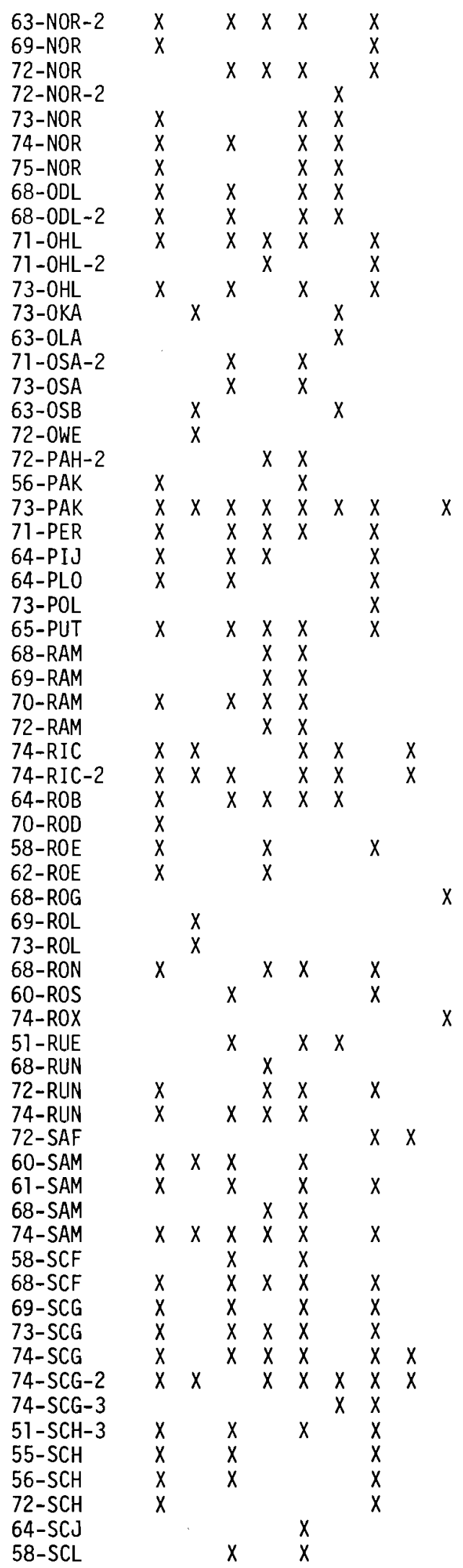
A. Exposures
B. Dosimetry
C. Excretion Data
D. External Counting
E. Body Burden Estimates
F. Autopsy Data
G. Therapy
H. Biological Effects
I. Psychosocial Effects

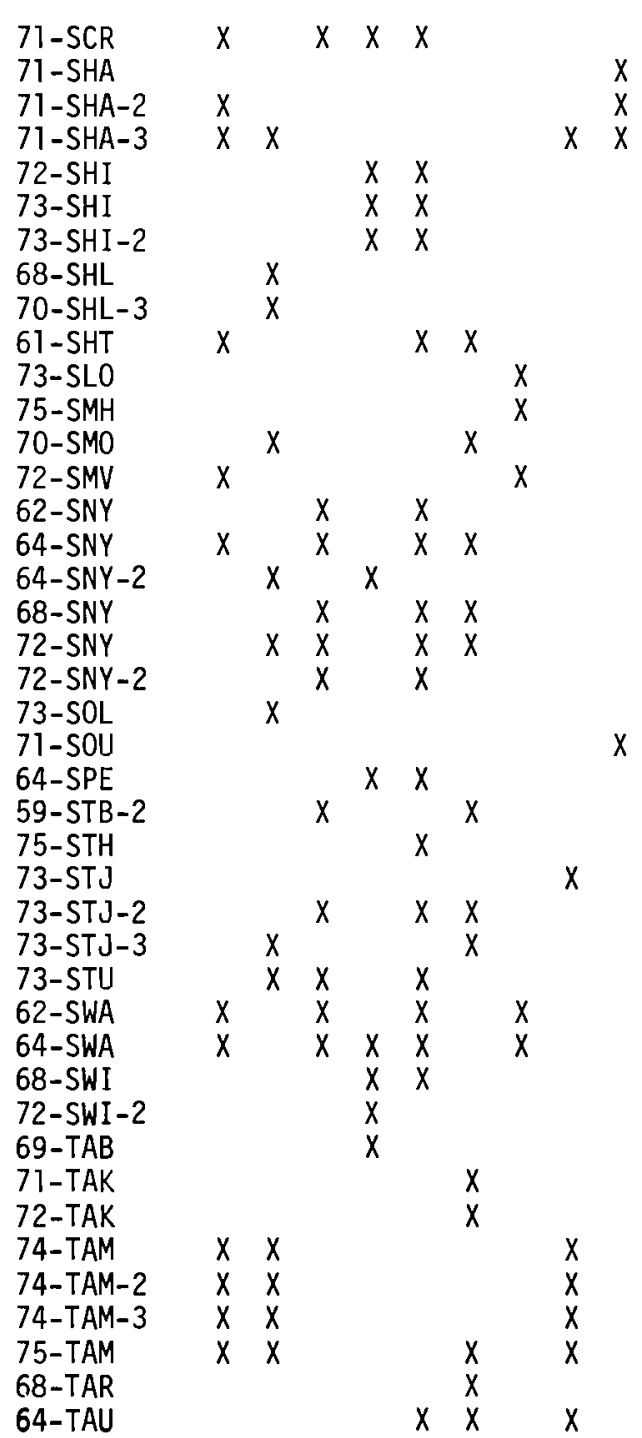


HUMAN EXPERIENCE
A. Exposures
B. Dosimetry
C. Excretion Data
D. External Counting
E. Body Burden Estimates
F. Autopsy Data
G. Therapy
H. Biological Effects
I. Psychosocial Effects

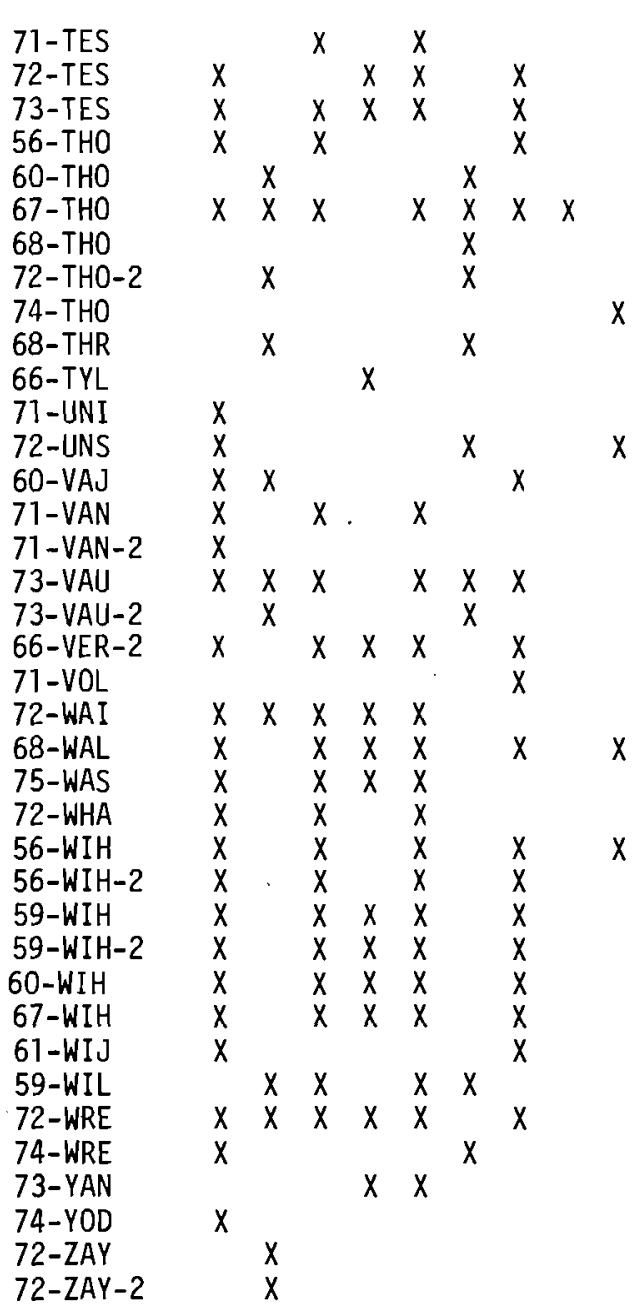


ENVIRONMENTAL DISTRIBUTION

$\underline{A} \underline{B} \quad \underline{C} \underline{D} \quad \underline{E} \quad \underline{F} \quad \underline{G} \underline{H} \quad \underline{I} \quad \underline{J} \underline{K}$

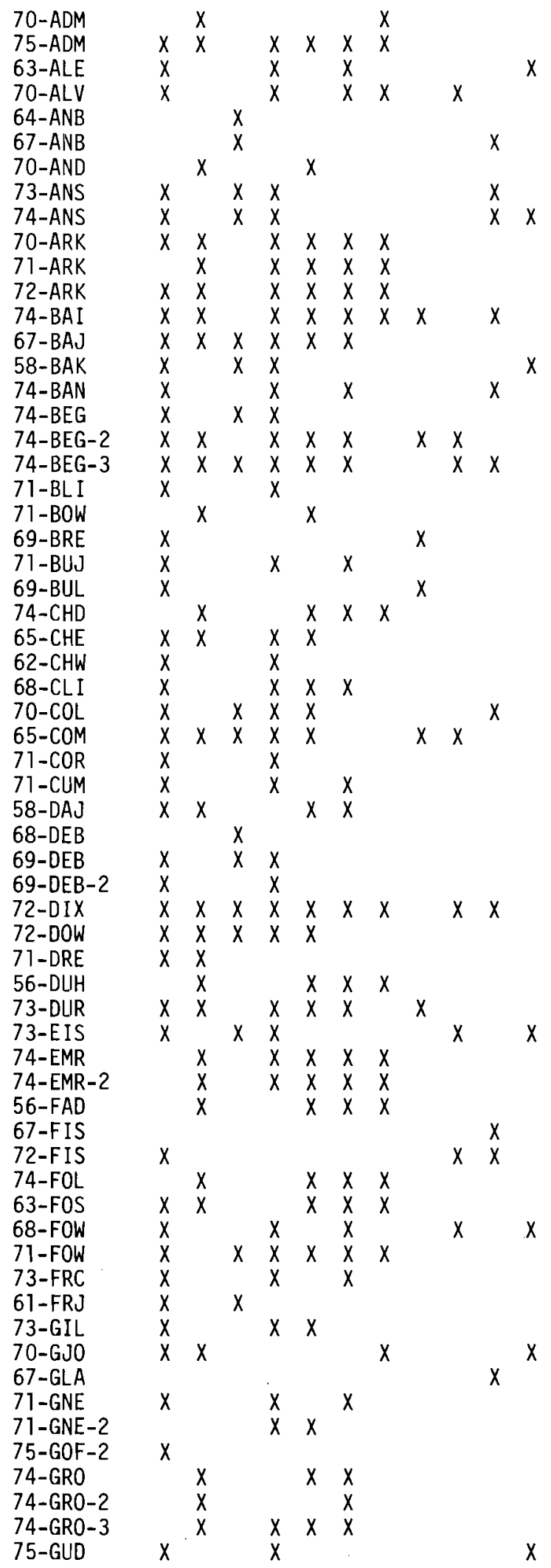

A. Terrestrial

B. Aquatic

C. Air

D. Soil or Sediments

E. Water

F. Plants

G. Wild Animals

H. Livestock

I. Food

J. Resuspension

k. Decontamination
$\underline{A} \quad \underline{B} \quad \underline{C} \quad \underline{D} \quad \underline{E} \quad \underline{F} \quad \underline{G} \quad \underline{H} \quad \underline{I} \quad \underline{J} \quad \underline{K}$

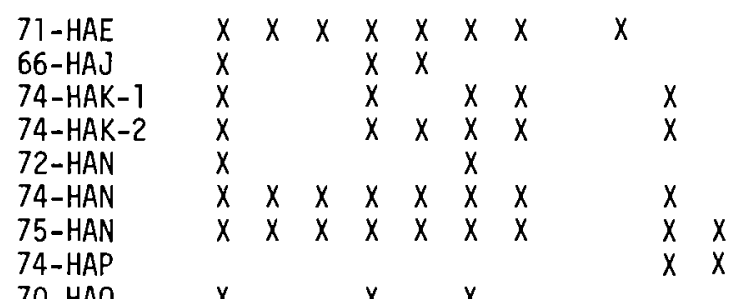

70-HAQ

71-HAR

72-HAR

72-HAR-2

73-HAR

74-HAR

71-HAS
71-HEA

71-HEA-2

74-HEA

71-HED

68-HOD

69-HOJ

75-HOM

73-HOV

74-HOV

74-HOV-2

70-INO

68-IRA

69-IRA

59-JAD

48-JAL

68-J0H

$67-\mathrm{JOI}$

$71-\mathrm{JOR}$

74-JOR

68-KAR

67-KAU

73-KEC

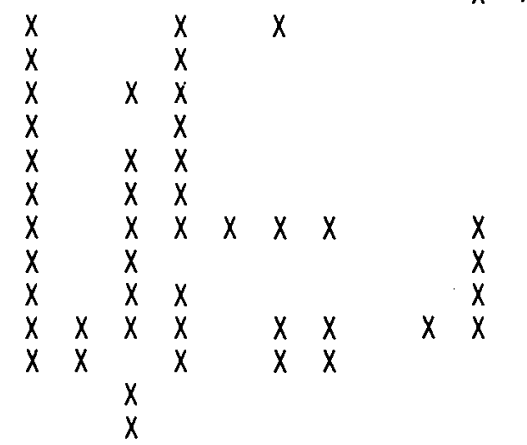


ENVIRONMENTAL DISTRIBUTION
A. Terrestrial
B. Aquatic
C. Air
D. Soil or Sediments
E. Water
F. Plants
G. Wild Animals
H. Livestock
I. Food
J. Resuspension
k. Decontamination

$\underline{A} \underline{B} \quad \underline{C} \underline{D} \quad \underline{E} \underline{F} \underline{G} \quad \underline{H} \quad \underline{I} \quad \underline{J} \underline{K}$

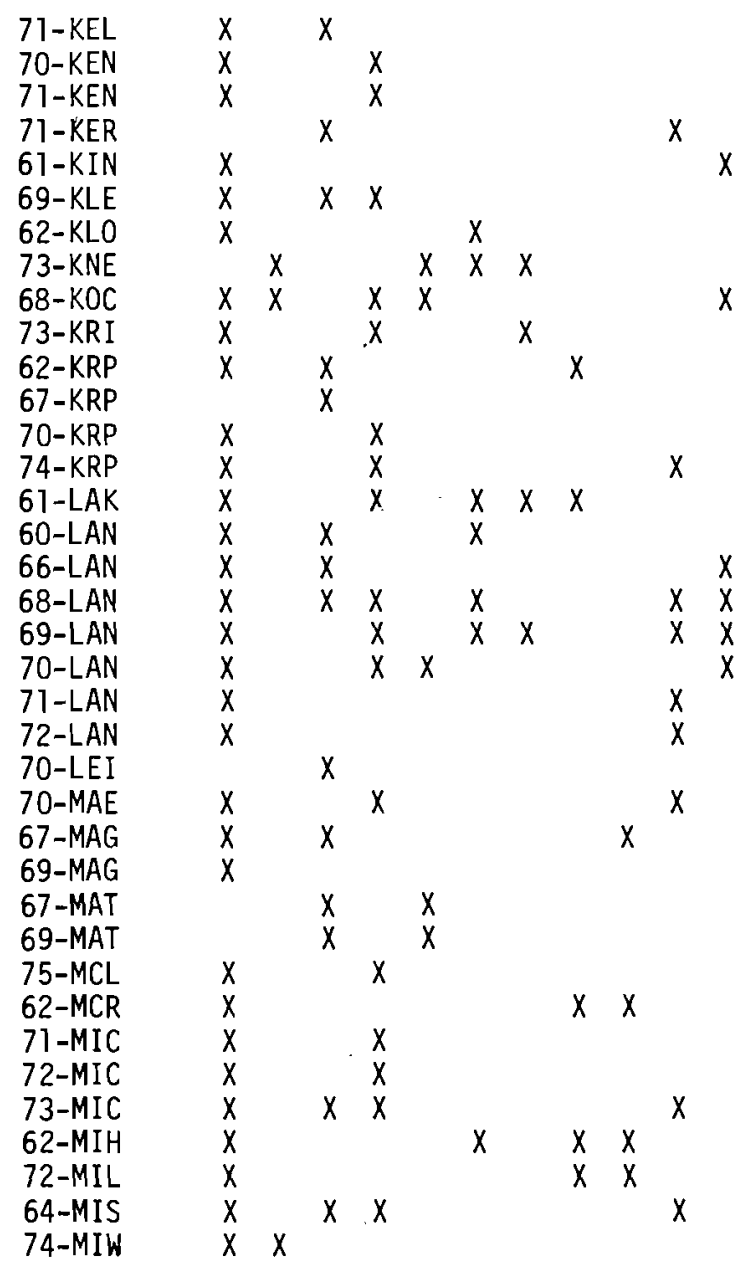

$$
\underline{A} \underline{B} \quad \underline{C} \underline{D} \underline{E} \quad \underline{F} \underline{G} \underline{H} \underline{I} \underline{J} \underline{K}
$$

68-MIY $X$

68-MIY-2

70-MIY

$71-M I Y$

74-MOA

75-MOG

$70-\mathrm{MOH}$

61-MOW

74-MLIH

61-NAT

72-NAT

75-NEA

74-NEV

68-NGY

65-NIS

72-NOR

71-NOS

72-NOS

72-NOS-2

74-NOS

74-NOS-2

68-ODL

68-ODL-2

73-OKA

45-OLA

63-OLA

60-OLS

63-OSB

71-PAI

73-PAK

$64-P E N$

71-PER

72-PET

64-PIL

72-POE

71-POW

71-PRI

72-PRI

73-PRI

73-PRI -2

58-PRW

70-PUR

55-RED

57-RHD

68-ROG

70-ROM

72-ROM
73-ROM

75-ROM

72-ROQ

71-RUA

63-RUS

66-RUS

66-RUS-2

64-SAB
$71-\mathrm{SAK}$

$71-S A K-2$

58-SCF

64-SCJ

74-SCU

73-SEL

71-SHA-3

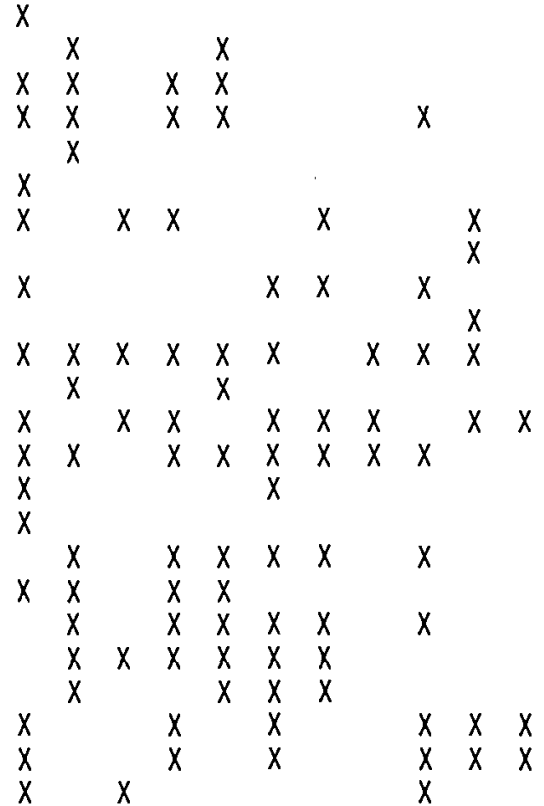

$x \quad x \quad x \quad \frac{x}{x} x^{x} \quad x \quad x \quad x \quad x$

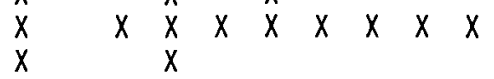

$x \quad x$

$\begin{array}{llllll}x & & x & x & x & x \\ x & x & x & x & x & x\end{array}$

$x$

$x=x$

$\begin{array}{llllll}x & x & x & x & x & x \\ x & & & x & x & x \\ x & & x & x & x & x\end{array}$

$\begin{array}{rrrrrr}x & x & x & x & x \\ x & x & x & x & x\end{array}$

$\begin{array}{llllll}x & x & x & x & x & x\end{array}$

$\begin{array}{llll}x & x & x & x\end{array}$

$x \quad x \quad x \quad x \quad x \quad x \quad x$

$\begin{array}{llllllll}x & x & x & x & x & x & & x \\ x & & x & & x & & & \\ x & & x & & x & & & \\ x & x & & x & x & x & x & \end{array}$

$\begin{array}{llllll}x & x & x & X & x & x\end{array}$

$x \quad x$

$\begin{array}{ll}x & x \\ x & x\end{array} x$

$\begin{array}{lllll}x & x & x & x & x\end{array}$

$\begin{array}{lllllll}x & x & x & x & & x & \\ x & x & x & x & x & x & x\end{array}$

$\begin{array}{llllll}x & x & x & x & x & x \\ x & x & x & & & x \\ x & x & x & & & x\end{array}$

$x+x \times x$

$x \stackrel{x}{x}$

$\begin{array}{lll}x & x & x \\ x & x & x \\ x & x & x\end{array}$

$x \quad x \quad x \quad x$

$\begin{array}{ll}x & x \\ x & x\end{array} \times x$

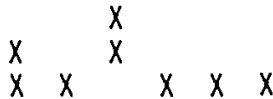

$\begin{array}{llllllllll}x & x & x & x & x & x & x & x & & x \\ x & & & x & & & & & & x\end{array}$ 
ENVIRONMENTAL DISTRIBUTION

$\underline{A} \underline{B} \underline{C} \underline{D} \underline{E} \underline{F} \underline{G} \underline{H} \underline{I} \underline{J} \underline{K}$

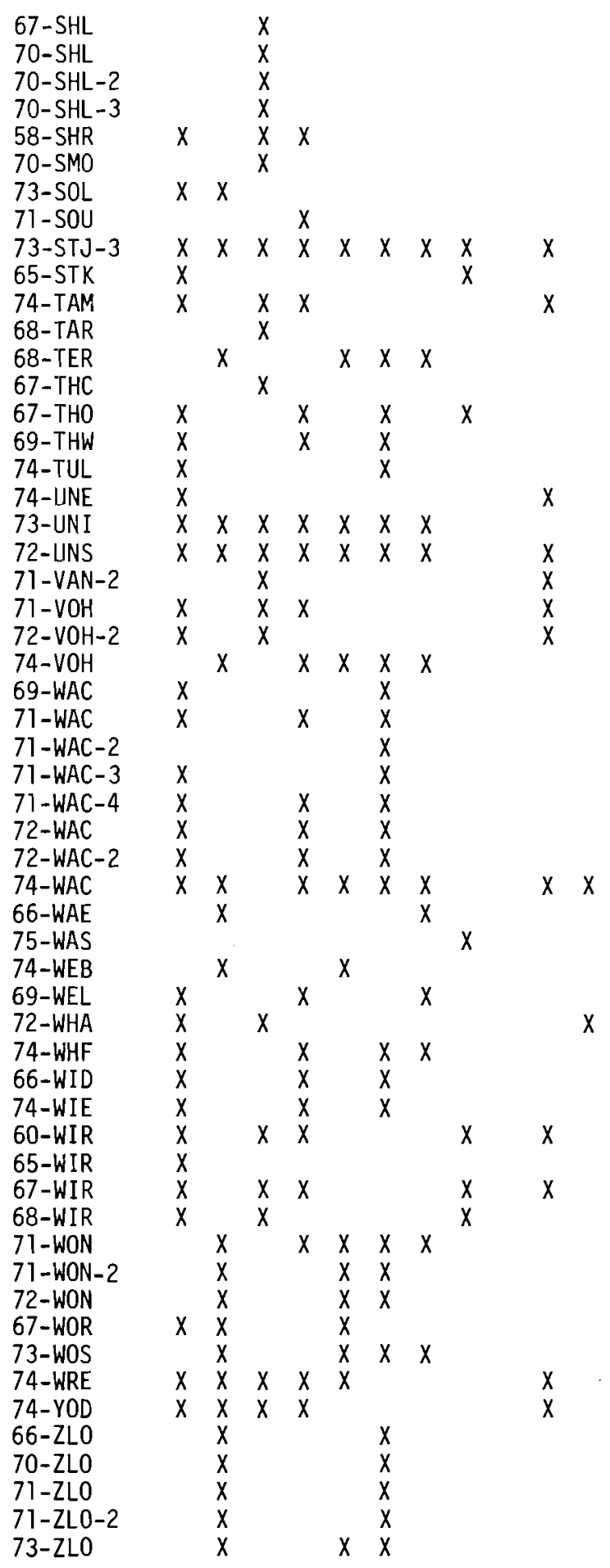
A. Terrestrial
B. Aquatic
C. Air
D. Soil or Sediments
E. Water
F. Plants
G. Wild Animals
H. Livestock
I. Food
J. Resuspension
K. Decontamination 
HAZARD EVALUATION
A. Dosimetry
B. Comparative Radio- nuclide Data
C. Standards
D. Hot Particles
E. Risk Estimates

$\underline{A} \underline{B} \underline{C} \underline{D}$

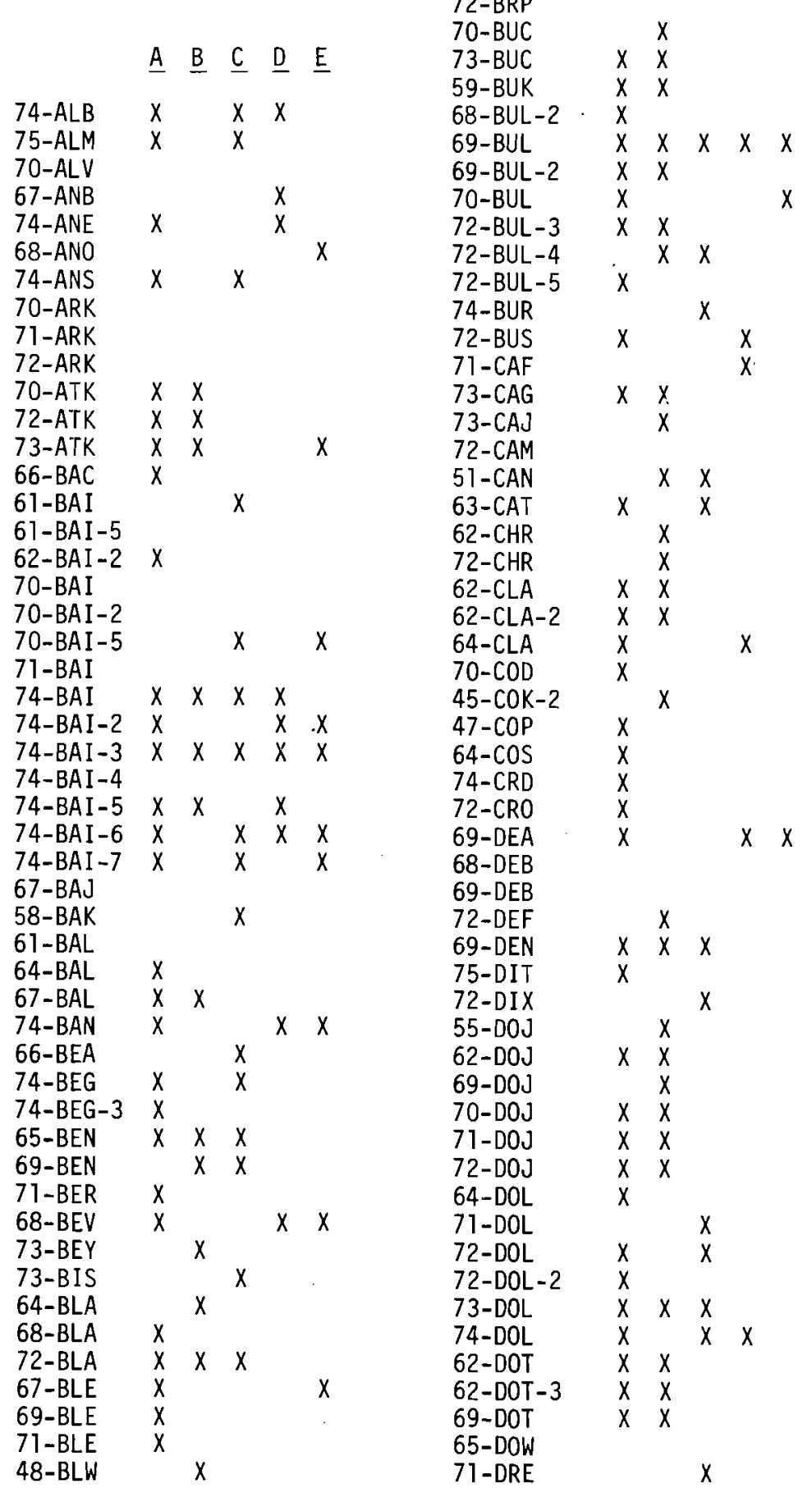

A B $\quad \underline{D} \quad \underline{E}$

$x$

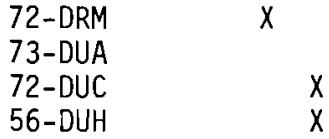

71-DUL

71-DUR

72-DUR-2

73-DUR

$72-E D L-2$

73-EIS

74-EMR-2

74-ERS

62-EVA

66-EVA

72-EVA

64-EVI

64-FAB

73-FAB

56-FAD

69-FAI

70-FAI

70-FAI -

74-FIL

53-FIN

$56-F I N$

59-FIN

68-F IN

45-FIR

50-FIR

67-FIS

72-FIS

67-FRD

61-FRJ

65-FUQ

72-GAV

74-GAV

68-GES

68-GES-2

74-GIL

74-GIL-3

75-GOF

75-GOF-2

73-GOM

71-GRI

75-HAI

66-HAJ

47-HAM

48-HAM

74-HAP

68-HAS

71-HAS

71-HAV

72-HAX

71-HAY

70-HAZ

71-HAZ

72- HAZ

72-HAZ-2

74-HAZ

74-HAZ-2

57-HEA

71-HEA

71-HEA-2

$x \quad x$

$x$

$$
\hat{x}
$$$$
\begin{array}{rr}
x & x \\
x & x \\
x & x \\
x & x \\
& x
\end{array}
$$

$x \quad x$

$x \quad x$

$x$
$x$

$x$

$x$
$x \quad x$
$x \quad x$

$x \quad x$

$x \hat{x}$

$x \quad x$

$x$
$x \quad x$

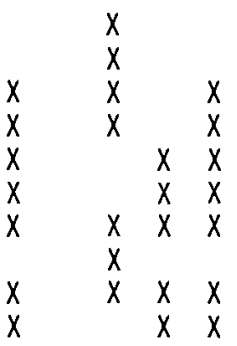

$x \quad x$

$x$

$x$

$x$

$x$

$x$
$x$
$x$

$X$

$X$

$x$

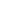$$
x
$$

$x$ 
HAZARD EVALUATION

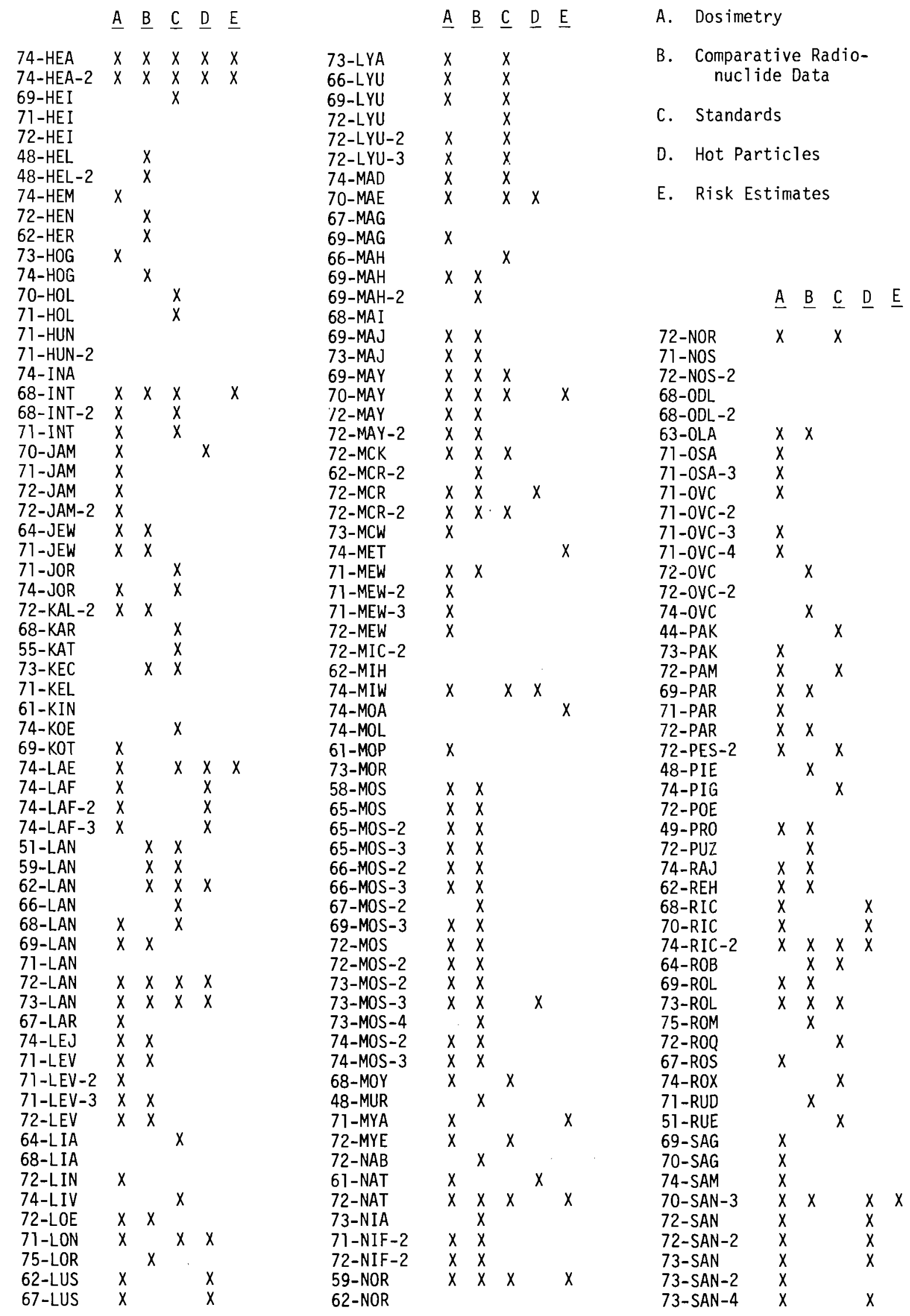


HAZARD EVALUATION
A. Dosimetry
B. Comparative Radio-
nuclide Data
C. Standards
D. Hot Particles
E. Risk Estimates

A B $\quad \underline{D} \quad \underline{E}$

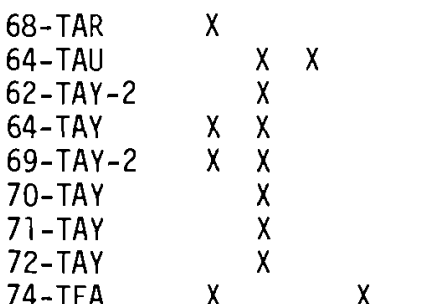

\section{A $\underline{B} \subseteq \underline{D} \underline{E}$}

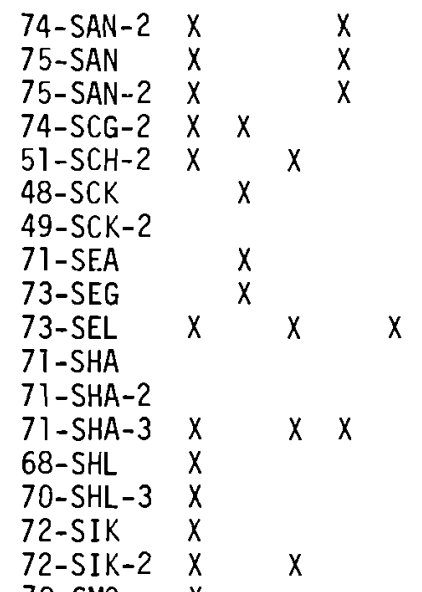

70-SMO

68-SMV

73-SOL $X$

71-SOU

68-SPI

$71-S P I$

59-STB

59-STB-2

62-STB

70-STB-2

72-STB-3 $x$

72-STB-4 $x$

72-STB-6 $\times \times \times$

73-STJ $x \quad x$

73-STJ-2 $x \times$

73-STJ-3 $x \quad x \quad x$

74-STJ $\times \times \times \times$

69-STK-2 $x$

45-STR

73-STU

57-STV

64-STV

57-SUL

60-SUL

74-SUIL

71-TAG

$x$
$x \quad x$
$x+x$

$x \quad x$

$x \quad x$

$x \quad x$

$x \quad x$

72-TAG

72-TAG-2 $\quad X \quad X$

72-TAG-3 $X$

74-TAM $x \times x \quad x \quad x$

74-TAM-2 $\times \times \times \times \quad \times$

74-TAM-3 $x \times x \quad x \quad x$

75-TAM $X \quad X X X$

\begin{tabular}{|c|c|c|c|c|c|}
\hline $\begin{array}{l}\text { 68-TAR } \\
64-T A U\end{array}$ & & \multicolumn{3}{|c|}{$x$} & \\
\hline $62-T A Y-2$ & & $\ddot{x}$ & & & \\
\hline 64-TAY & $x$ & $x$ & & & \\
\hline $69-T A Y-2$ & $x$ & $x$ & & & \\
\hline 70-TAY & & $x$ & & & \\
\hline $71-T A Y$ & & $x$ & & & \\
\hline 72-TAY & & $x$ & & & \\
\hline $\begin{array}{l}\text { 74-TEA } \\
68-T E R\end{array}$ & $x$ & & & $x$ & \\
\hline $56-\mathrm{THO}-2$ & & $x$ & $x$ & & \\
\hline 60-THO & $x$ & & & & \\
\hline $66-\mathrm{THO}$ & $x$ & & & $x$ & \\
\hline $\begin{array}{l}\text { 67-THO } \\
68-T H 0\end{array}$ & $x$ & $x$ & $x$ & & \\
\hline 72-THO-2 & $x$ & $x$ & $x$ & & $x$ \\
\hline 74-THO & $\ddot{x}$ & $x$ & & $x$ & \\
\hline $74-\mathrm{THO}-2$ & $\hat{x}$ & $\hat{x}$ & $x$ & $\ddot{x}$ & $x$ \\
\hline $\begin{array}{l}\text { 72-THR-3 } \\
73-T H U\end{array}$ & $x$ & & $\ddot{x}$ & $x$ & \\
\hline 66-TRE-2 & $x$ & $y$ & & & \\
\hline $\begin{array}{l}\text { b1-ISA } \\
69-T S E\end{array}$ & $x$ & $\hat{x}$ & & & \\
\hline 61-TWE & $x$ & & & & \\
\hline 74-UNE & $x$ & & & & \\
\hline 75-UNE & & & $x$ & & \\
\hline 73-UNI & $x$ & & & & \\
\hline 74-UNR & & & & & \\
\hline 72-UNS & $x$ & & & $x$ & $x$ \\
\hline 60 -VAJ & $x$ & $x$ & $x$ & & \\
\hline 74 -VAM & & & $x$ & & \\
\hline $\begin{array}{l}69-\text { VAN } \\
71-\text { VAN-2 }\end{array}$ & & & & & \\
\hline 56-VAU & & $x$ & & & \\
\hline 62-VAU & $x$ & & & & \\
\hline 65-VAU & $x$ & $x$ & $x$ & $x$ & \\
\hline 67-VAU & $x$ & & & $x$ & \\
\hline 71-VAU & $x$ & & & & \\
\hline 73-VAU & $x$ & $x$ & $x$ & $x$ & \\
\hline 73-VAU-2 & $x$ & $x$ & $x$ & & \\
\hline $72-V O H-2$ & & & & $x$ & \\
\hline $74-$ VOL -3 & & $x$ & & & \\
\hline 74-WAC & & & $X$ & & \\
\hline 71-WAF & $x$ & $x$ & $x$ & & \\
\hline 56-WEK & & & $x$ & & \\
\hline 59-WIL & $x$ & $x$ & $x$ & & \\
\hline 53-WIP & & $x$ & & & \\
\hline 60-WIR & & & & & \\
\hline 68-WIR & $x$ & & & & \\
\hline 71-WIT & & $x$ & & & \\
\hline 73-WOS & $x$ & & & & \\
\hline $68-Z A L$ & & $x$ & & & \\
\hline $72-Z A L-2$ & & $x$ & & & \\
\hline 72-ZAY & $x$ & $x$ & & $x$ & \\
\hline 72-ZAY-2 & $x$ & & & $x$ & \\
\hline
\end{tabular}


BNWL-2056

UC -48

DISTRIBUTION

No. of

Copies

OFFSITE

1 ERDA Chicago Patent Group

A. A. Churm

13 ERDA Division of Biomedical and

Environmental Research

N. F. Barr

C. E. Carter

R. D. Cooper

C. W. Edingten

C. H. Hobbs

M. L. Minthorn

C. Osterberg

D. H. Slade

J. Swinebroad

B. W. Wachholz

R. L. Watters

W. W. H. Weyzen

R. W. Wood

1 ERDA Division of Nuclear Research \& Applications

T. J. Dobry

27 ERDA Technical Information Center

\section{ONSITE-HANFORD}

1 ERDA Richland Operations of fice P. G. Holsted

2 Atlantic Richfield Hanford

Company

G. E. Backman

K. R. Price

2 Hanford Environmental Health

Foundation

B. Breitenstein

W. D. Norwood
No of

Copies

ONSITE-HANFORD (Continued)

280

Battelle-Northwest

Technical Information (3)

W. J. Bair

J. E. Ballou

J. P. Corley

D. K. Craig

G. E. Dagle

H. Drucker

L. L. Eberhardt

C. E. Elderkin

R. F. Foster

M. E. Frazier

M. F. Gill is

P. L. Hackett

K. R. Heid

F. P. Hungate

E. L. Klepper

J. E. Lund

D. D. Mahlum

S. Marks

B. J. McClanahan

J. E. Morris

I. C. Nelson

C. E. Newton, Jr.

J. F. Park

H. M. Parker

H. A. Ragan

W. H. Rickard

C. L. Sanders

L. C. Schwendiman

G. A. Sehme1

M. R. Sikov

V. H. Smith

J. K. Soldat

B. 0. Stuart

M. F. Sullivan

R. C. Thompson (240)

B. E. Vaughan

R. E. Wildung

W. R. Wiley 